FERNANDO HELLMEISTER CLITO FORNACIARI

\title{
DENUNCIAÇÃO DA LIDE
}

\section{NO DIREITO BRASILEIRO}

Tese para obtenção do título de Doutor

sob orientação do Professor José Rogério Cruz e Tucci

Faculdade de Direito da Universidade de São Paulo São Paulo 


\section{AGRADECIMENTO}

Agradeço ao Professor José Rogério Cruz e Tucci, pela importante orientação, que me auxiliou a delimitar o tema do presente estudo, desenvolvê-lo e aprimorá-lo.

Agradeço aos Professores Rodolfo de Camargo Mancuso e José Baptista Puoli, pelos valiosos comentários na banca de qualificação, que foram relevantes para o desenvolvimento do presente trabalho.

Agradeço a meu pai, Clito, pela orientação e constante apoio, a minha mãe, Maria Teresa, pela revisão do texto, a minha irmã, Flávia, pela contribuição ao longo de toda pósgraduação, a minha mulher, Virgínia, pela compreensão da exiquibilidade do meu tempo e pelo indispensável incentivo, e a minha filha, Júlia, pela inspiração. 
A minha mãe, Maria Teresa, pelos ensinamentos de vida e incentivo ao estudo, indispensáveis para o desenvolvimento deste trabalho. 


\section{SUMÁRIO}

1. Introdução

2. Das partes e dos terceiros ......................................................................................................... 04

2.1. Do conceito processual de parte ……………………………………………….... 04

2.2. Do conceito processual de terceiro .......................................................................... 07

2.3. Dos terceiros e admissibilidade da intervenção no processo ......................................... 09

2.4. Da modalidade e iniciativa de intervenção de terceiros .............................................. 13

2.5. Do tratamento legal da intervenção de terceiros ..................................................... 15

3. Dos institutos afins à denunciação da lide ........................................................................ 04

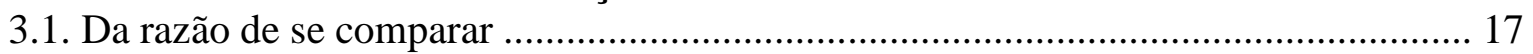

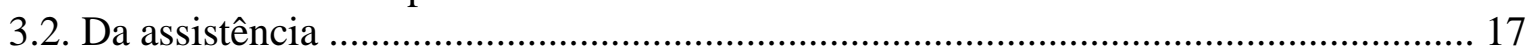

3.2.1. Da origem e evolução do instituto ...................................................................... 17

3.2.2. Da noção e importância do instituto .................................................................... 19

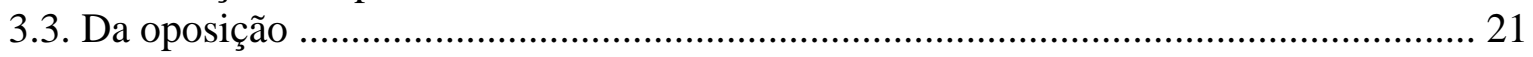

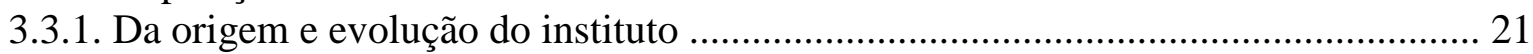

3.3.2. Da noção e importância do instituto ...................................................................... 22

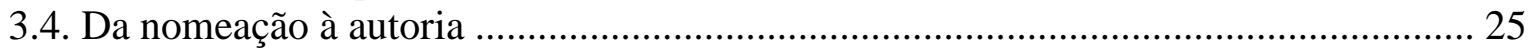

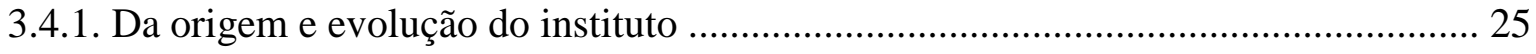

3.4.2. Da noção e importância do instituto ................................................................... 25

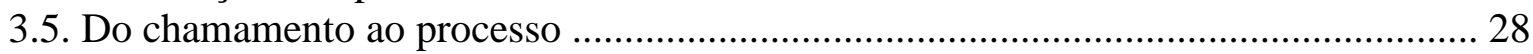

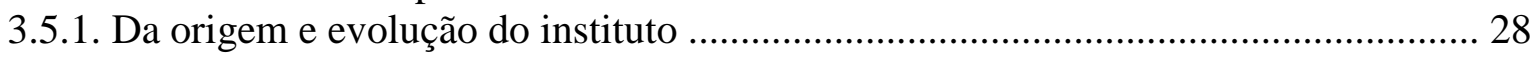

3.5.2. Da noção e importância do instituto ..................................................................... 29

4. Da denunciação da lide ......................................................................................................... 33

4.1. Da origem e evolução do instituto até o Código de Processo Civil de 1973 ............... 33

4.2. Da noção e importância da denunciação da lide ........................................................ 42

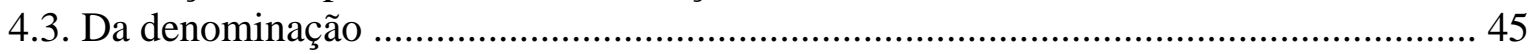

4.4. Do processo de conhecimento como aquele em que tem lugar a denunciação ............ 47

4.5. Da dita obrigatoriedade da denunciação …………………………………………... 50

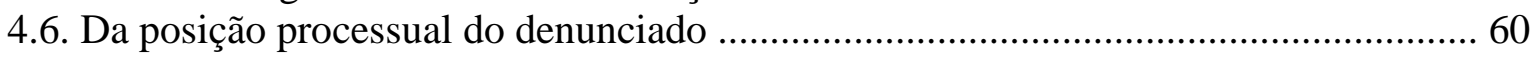

5. Das hipóteses de cabimento de denunciação da lide ..................................................... 69

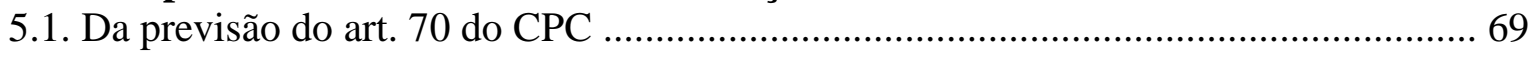

5.1.1. Da denunciação da lide nos casos de evicção ......................................................... 70

5.1.2. Da denunciação da lide pelo possuidor direto .......................................................... 75

5.1.3. Da denunciação da lide para os demais casos de direito regressivo ......................... 79

5.1.3.1. Do debate em torno da limitação ao art. 70, III, do CPC ...................................... 81

5.2. Da faculdade da denunciação pelo autor .................................................................. 88

5.3. Da denunciação da lide pelo Estado ao agente público responsável pelo dano ........... 91

5.4. Da denunciação da lide do segurado ao segurador ...................................................... 98

5.4.1. Da ação direta da vítima do ato ilícito em face do segurador ................................... 100

5.5. Das outras hipóteses de denunciação da lide .............................................................. 105 
5.6. Da intervenção de terceiro em ação voltada à fixação da obrigação alimentar ......... 106

5.7. Das limitações da denunciação da lide no Código de Defesa do Consumidor .......... 112

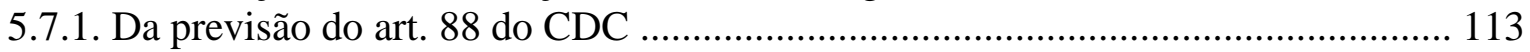

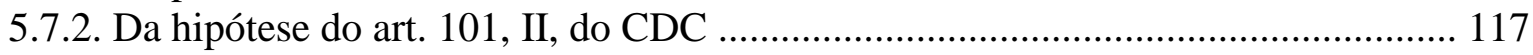

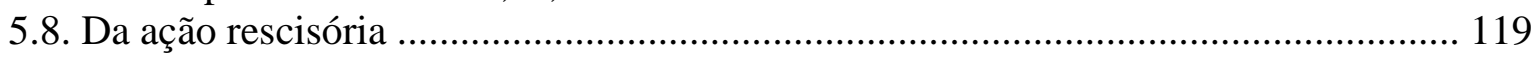

6. Das regras procedimentais para a denunciação da lide .............................................. 122

6.1. Da competência para processar e julgar a denunciação da lide ................................ 122

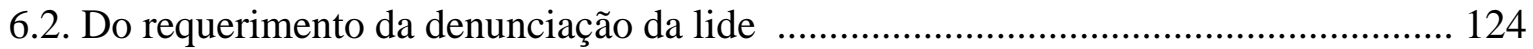

6.3. Dos atos e posturas do denunciante que repercutem na denunciação ......................... 130

6.3.1. Da revelia do denunciante e denunciação da lide ................................................. 131

6.3.2. Da confissão dos fatos pelo denunciante e denunciação da lide ............................ 133

6.3.3. Do reconhecimento jurídico pelo denunciante e denunciação da lide .................... 133

6.3.4. Da transação entre o denunciante e seu adversário na ação principal e denunciação

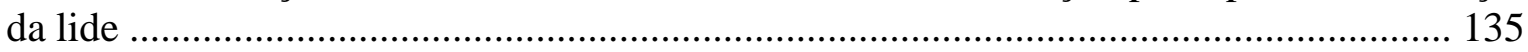

6.3.5. Da preliminar de ilegitimidade passiva na ação principal e denunciação da lide .. 139

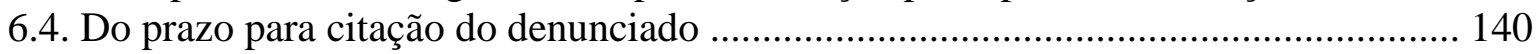

6.5. Dos desdobramentos da denunciação da lide feita pelo réu ...................................... 143

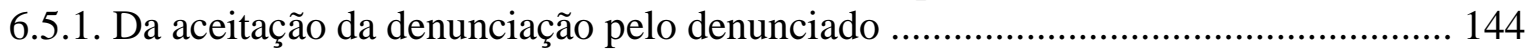

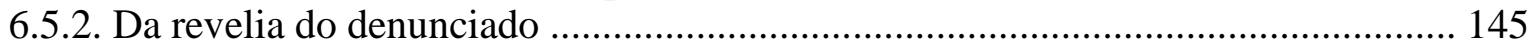

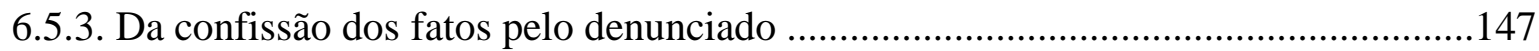

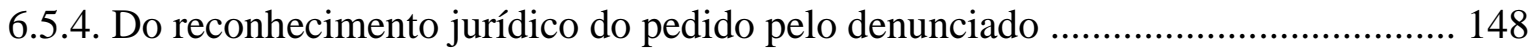

6.5.5. Da transação entre o denunciado e o adversário do denunciante ............................ 149

6.6. Do recurso contra a decisão sobre cabimento da denunciação da lide ....................... 150

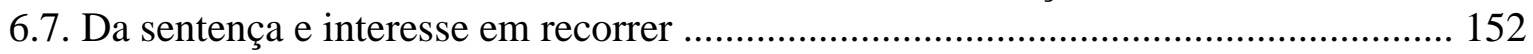

6.8. Da condenação direta do denunciado frente ao adversário do denunciante ............... 155

6.9. Da penhora dos direitos relativos ao seguro de responsabilidade civil ..................... 165

6.10. Da denunciação da lide sucessiva e per saltum ...................................................... 167

6.11. Da fixação dos ônus sucumbenciais na lide secundária ......................................... 175

7. Da denunciação da lide no projeto do novo Código de Processo Civil ................... 181

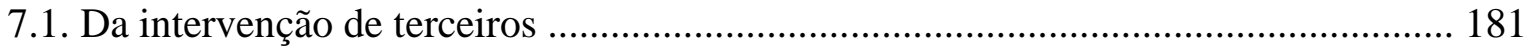

7.2. Da denunciação da lide (chamamento em garantia) ............................................. 185

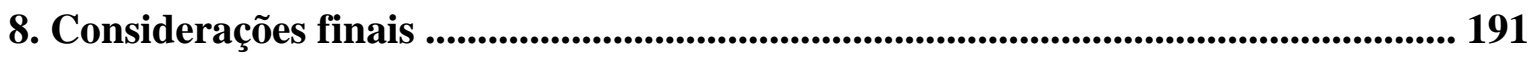

Bibliografia

Resumo ............................................................................................................................................ 205

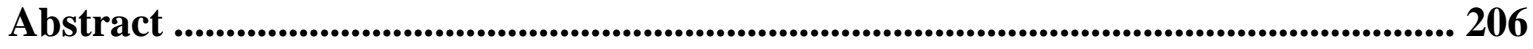

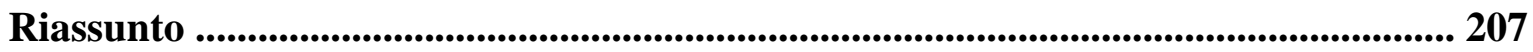




\section{INTRODUÇÃO}

O objetivo do presente trabalho é o estudo do instituto da denunciação da lide no direito brasileiro, especialmente no processo civil, buscando não apenas identificar suas características, mas também analisar a dinâmica de seu funcionamento e as consequências que advêm de sua utilização para o processo. A par dessa análise, igualmente se pretende abordar a legislação vigente de forma crítica, identificando os modos pelos quais o emprego do instituto pode contribuir para maior efetividade do processo, sem que se violem regras e princípios legais.

O interesse pela denunciação da lide surge da utilidade do instituto para a estrutura do sistema processual, permitindo a esta maior economia e efetividade, em termos de resultado. Cuida-se, nesse sentido, de importante modalidade de intervenção de terceiros, por meio da qual o autor ou o réu chama a juízo, para atuar no mesmo processo, terceiro, que possui relação jurídica de direito material apenas com o denunciante, mas não com a parte contrária deste, em vista da ausência de vínculo direto entre eles. Assim, torna-se possível, ao final de um só processo, resolverem-se conjuntamente duas relações jurídicas que poderiam ser objeto de lides sucessivas.

Trata-se de modalidade de intervenção de terceiros relevante, por conferir oportunidade de o denunciante buscar auxílio do denunciado para melhor defender seus interesses e resguardar-se de eventual sucumbimento, por já exercer, ao mesmo tempo, uma ação de regresso.

A reforçar a razão de um estudo amplo e profundo, destaca-se que o instituto, embora não seja moderno e não tenha sido criado nas várias reformas processuais, prende-se a concepções ultimamente prestigiadas pelo legislador. Nesse sentido, valoriza os princípios da economia, da celeridade e da efetividade do processo, bem como contribui para a pacificação social, por ser instrumento eficaz para resolver, de uma única vez, mais de uma relação jurídica, e por conferir, como consequência, maior 
estabilidade e segurança jurídicas, preservando o interesse público e evitando até mesmo decisões conflitantes, que poderiam ocorrer em outros sucessivos processos.

Em vista disso, possui grande aplicação na vida forense, já que é instrumento que possibilita, num único processo, decidir a relação jurídica entre o autor e réu, bem como a do denunciante e do denunciado. Desse modo, possibilita que uma única instrução probatória e uma só sentença resolvam todas as questões, eliminando o risco de decisões contraditórias e facilitando, inclusive, o cumprimento dos provimentos jurisdicionais, o que é benéfico para as partes e também para o próprio Judiciário. Evita-se, assim, o desperdício de tempo e a prática de atos processuais possivelmente idênticos ou, ao menos, muito similiares.

A importância do tema é realçada por força das situações que permitem a denunciação. $O$ instituto é bem controverso, a partir da imprecisa redação da lei processual, que, ao elencar as situações de denunciação, diz ser ela obrigatória, representando verdadeira condição para se obter indenização. Esta suposta obrigação exige cautela e deve ser examinada em confronto com as situações de direito material que ensejam denunciação, a fim de não radicalizar o instituto.

É certo que o aplicador do direito encontra-se, muitas vezes, em situações delicadas ao tratar da denunciação, dado que sua aplicação poderá, eventualmente, retardar a prestação da tutela jurisdicional, em vista da dificuldade de citar o denunciado ou da necessidade de a denunciação enfrentar fundamento ou fato novo, exigindo produção de provas diferentes das necessárias para a demanda principal. O legislador não impõe uma solução e isso cria enorme divergência sobre o equilíbrio que se deve buscar, conferindo preferência à rápida prestação da tutela jurisdicional ou à finalidade da denunciação da lide.

O instituto já passou por radicais transformações ao longo de sua evolução histórica, o que aumenta, ainda mais, sua importância, até porque cada legislação lhe atribui características diferentes, o que demonstra toda sua riqueza. Nesse sentido, são marcantes o aprimoramento e a evolução do instituto do Código de Processo Civil de 1939 para o de 1973, ao mesclar as características do modelo do direito romano e do direito germânico primitivo e não se restringir apenas às hipóteses de evicção. 
A partir da previsão do Código de Defesa do Consumidor, situações possibilitam a aplicação do instituto, como as hipóteses em que se discute prestação de serviços (art. 14 do CDC); outras, porém, vedam sua possibilidade de maneira expressa (art. 13 do CDC).

As mudanças na legislação civil do Código de 1916 para o de 2002 também afetaram a denunciação diretamente, como as relativas ao contrato de seguro de responsabilidade civil, que se transformou em instrumento de garantia (art. 787 do CC), podendo a vítima do dano demandar tanto em face do causador do prejuízo, como do seu segurador, implantando hipótese de co-obrigação entre eles. Isso tem sido considerado denunciação da lide às avessas e merece um estudo minucioso.

Sem dúvida alguma, inovações introduzidas pelo novo Código Civil, em relação a institutos que transitam pela denunciação e que receberam nova roupagem ainda não completamente absorvida pela doutrina e pela jurisprudência - afetaram a denunciação, revelando-se importante, logicamente, perquirir essas hipóteses, a fim de precisar-se seu alcance.

Por fim, caso o projeto de novo Código de Processo Civil venha a ser aprovado e entre em vigor, virão à tona novas alterações, evidenciando que se cuida de instituto que segue em contínua mutação e exige maior reflexão, notadamente porque, apesar das mudanças verificadas, o legislador não se preocupou em eliminar, expressamente, algumas controvérsias, no sentido de proporcionar maior efetividade ao processo. Com isso, subsiste o interesse da doutrina em enfrentar as questões que daí advêm. 


\section{DAS PARTES E DOS TERCEIROS}

2.1. Do conceito processual de parte. O conceito de parte, na história do direito processual, sofreu muitas mudanças, partindo de uma definição associada ao direito substancial, que, diante da autonomia alcançada pelo direito processual, perdeu, em parte, destaque e força ${ }^{1}$. De qualquer maneira, o legislador processual não se preocupou em definir parte, tratando apenas da capacidade de quem pode estar em juízo, da legitimidade, da condição da ação, dos deveres das partes e da substituição delas.

Diante do silêncio da lei, os doutrinadores procuraram chegar à definição. Não por acaso que se reconhece que a "noção de 'parte' admite variantes de conformidade com a perspectiva adotada, apresentando-se, pois, como um conceito polissêmico"2. Apesar da existência de distintos conceitos, do caráter instrumental do processo e da inegável simbiose junto ao direito material, interessa-nos, em razão do foco do estudo, apenas a variante processual, sobre o qual nos deteremos.

A definição mais difundida é a de GIUSEPPE CHIOVENDA, ao dizer que "o conceito de parte entronca-se no conceito do processo e da relação processual: parte é aquele que demanda em seu próprio nome (ou em cujo nome é demandada) a atuação de uma vontade da lei, e aquele em face de quem essa atuação é demandada". Afasta-se da relação substancial e conclui que a relação processual "e as partes existem com a simples afirmação da ação, independentemente de sua existência efetiva, cuja averiguação constitui, exatamente, objeto da lide" 3 .

\footnotetext{
${ }^{1}$ É forte entre os processualistas a tendência de buscar a definição de parte no direito processual. Para José Manoel de Arruda Alvim Netto, o conceito de parte é "eminentemente processual, resultando, como já se observou, da simples afirmação da ação. Decorre do fato da propositura da ação" (Manual de direito processual civil, v. 2, p. 18). Já Athos Gusmão Carneiro afasta-se da relação substancial deduzida em juízo, ao afirmar que a doutrina prevalecente "liga o conceito de parte à atividade tutelar do Estado mediante a atividade dos órgãos do Poder Judiciário, proteção que a Constituição a todos promete e assegura (CF de 1988, art. $5^{\circ}$, XXXV)" (Intervenção de terceiros, p. 5).

${ }^{2}$ José Rogério Cruz e Tucci, Limites subjetivos da eficácia da sentença e da coisa julgada civil, n. 3, p. 25.

${ }^{3}$ Instituições de direito processual civil, v. 2, n. 214, p. 234-235.
} 
Assim sendo, é autor quem postula a tutela jurisdicional e réu, aquele em face de quem se pede algo ${ }^{4}$. Esses conceitos são de natureza processual e deixam de lado a relação de direito material, em virtude de não influir na definição. Por essa perspectiva, é irrelevante considerar a posição do sujeito diante do direito material ${ }^{5}$. Apenas para exemplificar, em uma ação de cobrança, o autor é o que cobra e o réu, aquele que é cobrado, porém, se a ação for julgada improcedente, em razão de o valor cobrado já ter sido pago, o autor e o réu não deixarão de ser partes e continuarão a ocupar a mesma posição processual. Ter ou faltar razão ao sujeito é questão distinta, que se distancia do direito no plano processual, em razão de ter pertinência associada apenas ao direito material, até mesmo porque no processo um será vencedor e o outro vencido ou ambos serão reciprocamente vencedores e vencidos ${ }^{6}$.

Parece-nos correta essa concepção processual do conceito de parte. Tanto o autor como o réu não deixarão de ser partes, mesmo que não sejam titulares da relação de direito material objeto do litígio. Dessa forma, o conceito de parte no processo não se deve misturar com o conteúdo do plano material, intimamente ligado à parte legítima. Ainda que o autor ou o réu não possuam correlação com os que têm relação de direito material, eles serão partes no processo, por serem os integrantes da relação jurídico-processual.

Para a parte assumir processualmente essa condição, é indiferente que a relação jurídica se forme entre os verdadeiros titulares do direito objeto da lide. Na realidade, aquele que não for o efetivo titular do direito material debatido não terá legitimidade para figurar no polo ativo ou passivo, porém será parte na relação processual. Assim, o direito

\footnotetext{
${ }^{4}$ Cf. Cássio Scarpinella Bueno, ao adotar a orientação de Chiovenda e restringir o conceito de parte "para quem 'provoca' a jurisdição e perante quem se pede a prestação da tutela jurisdicional" (Partes e terceiros no processo civil brasileiro, p. 3).

${ }^{5}$ Nesse sentido, pertinentes as colocações de Alfredo de Araújo Lopes da Costa, ao afirmar que serão partes "aquelles em cujo nome ou em face dos quaes se pede uma actuação da lei. Não entra aqui elemento algum de direito substantivo. A relação tem um conteúdo puramente processual. Sob esse ponto de vista, indiferente é que ella se forme entre os verdadeiros ou entre os pretensos titulares do direito trazido à lide. Autor e réo podem não ser os 'sujeitos do direito', mas se apresentam como os da aç̧ão: surgem como os 'senhores do processo"” (Da intervenção de terceiros no processo, p. 11).

${ }^{6}$ Segundo Crisanto Mandrioli, pouco importa se a parte tem ou não o direito, bastando para caracterizá-la a existência do processo, ao afirmar que "Potrà, insomma, mancare il diritto fatto valere, mancare l'azione, mancare perfino il potere de proporre la domanda in chi, ciononostante, l'ha proposta: ma se c'è uma domanda, c'è um processo e quindi la parte". Ressalta, ainda, que o legislador italiano também não define o conceito de parte e sustenta, ao preocupar-se com a linguagem jurídico processual, que "parti nel processo sono dunque quei soggetti che compiono gli atti del processo, ne subiscono gli effetti e nono perciò $\mathrm{i}$ destinatari dei provvedimenti del giudice" (Corso de Diritto Processuale Civile, p. 176-179).
} 
material torna-se relevante apenas para caracterizar a legitimidade de parte, mas não propriamente para estabelecer o conceito de parte ${ }^{7}$.

Além dessa clássica concepção do conceito de parte, há corrente sustentada por ENRICO TULLIO LIEBMAN, que considera partes os sujeitos do contraditório instituído perante o juiz ${ }^{8}$. A partir desse prisma, associa-se parte ao sujeito que possui interesse e é parcial, de modo que exclui o juiz que, embora seja sujeito processual, não tem interesse no litígio e é, portanto, imparcial, o que é fundamental para poder exercer suas funções no processo (arts. 134, I, e 135, V, do CPC). Essas características distintas são decorrência da circunstância de o juiz não ter, por lógico, seus direitos atingidos pela decisão judicial e não ser alcançado pela autoridade da coisa julgada material, diferentemente do que ocorre com as partes, a reforçar, claramente, a diferença da posição processual entre eles.

A circunstância de alguém ser parte no processo confere a esse sujeito "poderes, faculdades, ônus, deveres, sujeição"" , que refletirão sobre ele. A depender de sua postura, os efeitos de seu comportamento lhe serão atribuídos. Se o sujeito não for parte, não poderá agir em juízo, não terá poderes, faculdades, ônus e deveres, bem como, por consequência, não será atingido pelos atos praticados no processo. Parece-nos que essa visão do conceito de parte constitui mais uma qualidade ou característica - que variará de acordo com sua conduta no processo - do que propriamente um elemento para defini-lo, mas, de qualquer maneira, é relevante.

\footnotetext{
7 Seguindo essa clássica definição de conceito de parte, Leo Rosenberg afirmou, ao tratar da natureza puramente processual, que "partes em el proceso civil son aquellas personas que solicitan y contra las que se solicita, em nombre propio, la tutela jurídica estatal, em particular la sentencia y la ejecución forzosa. Este concepto del derecho procesal alemán (único decisivo) es indepediente de la estructura del derecho material y de la posición jurídica extraprocesal de los interesados. Porque no es parte en el proceso civil como titular de la relación jurídica controvertida, sino actor es quien afirma el derecho (material); y demandado, aquel contra quien se lo hace valer. Para la posición de parte procesal no tiene importancia si el actor es el poseedor del derecho y si el demandado es el verdadero obligado o afectado" (Tratado de Derecho Procesal Civil, p. 211). Nesse mesmo sentido, Sérgio Ferraz diz que o conceito tradicional de parte é aquele que pede e contra quem é pedida determinada providência jurisdicional (Assistência litisconsorcial no direito processual civil, p. 51).

${ }^{8}$ Ressalta que "sono parti nel processo i soggetti del contradittorio istituito davanti al giudice, i soggetti del processo diversi dal giudice, nei cui confronti quest'ultimo deve pronunciarei il suo provvedimento. La domanda giudiziale, come atto costitutivo del processo determina anche le parti: quella che chiede al giudice di provvedere su um determinato oggetto e quella nei cui confronti il provvedimento è chiesto" (Manuale de diritto processuale civile, p. 82). Associando o conceito de parte ao princípio do contraditório, v. Cândido Rangel Dinamarco (Intervenção de terceiros, n. 3, p. 17; e Instituições de direito processual civil, n. 520, p. 246-249) e Vicente Greco Filho (Da intervenção de terceiros, p. 28).

9 Além de ressaltar o princípio do contraditório, Cândido Rangel Dinamarco destaca essa particularidade própria das partes, ao dizer que são "titulares das diversas situações jurídicas ativas ou passivas inseridas na dinâmica da relação jurídica processual” (Intervenção de terceiros, n. 3, p. 17).
} 
Buscamos destacar todas essas perspectivas do conceito de parte no processo, a fim de demonstrar que elas estão associadas ao plano processual e afastam-se, por completo, do direito material. Assim, o conceito processual de parte não depende do direito substancial posto em juízo, que, de outro lado, é fundamental "para a determinação da possibilidade de terceiros intervirem no processo, nas diversas hipóteses admitidas pelo estatuto processual" ${ }^{\prime 10}$.

Assim, adquirirá a qualidade de parte o autor, ao ajuizar a demanda; o réu, ao ser instaurada a relação jurídica processual; aquele que suceder o autor ou o réu em razão do falecimento das partes, em decorrência de ato ou negócio jurídico; e o terceiro que for admitido no processo pendente, por meio de uma das modalidades de intervenção de terceiro ou por força de decisão judicial, que, por exemplo, desconsidere a personalidade jurídica da sociedade devedora, atingindo os sócios.

2.2. Do conceito processual de terceiro. A partir do conceito processual de parte, é possível construir o de terceiro, que é importante para o objeto deste estudo, até mesmo porque o legislador processual distinguiu-o das partes, sem também conceituá-lo, mas tratando dele e regulando-o em diversos dispositivos.

Nosso interesse com a definição de terceiro, da mesma maneira que fizemos em relação ao conceito de parte, é contextualizá-lo no plano processual, não nos preocupando com a relação de direito material, pois não se está cuidando apenas dos terceiros legitimados. A definição será restrita somente ao processo ${ }^{11}$, mas não ao litígio.

É comum o terceiro ser definido, na doutrina, de modo negativo, ou seja, contrapondo-se à parte ${ }^{12}$. A partir do clássico conceito chiovendiano, consideram-se

\footnotetext{
${ }^{10}$ José Roberto dos Santos Bedaque, Direito e processo - influência do direito material sobre o processo, $\mathrm{n}$. 26.2., p. 129.

${ }^{11}$ Ao identificar o conceito processual de parte, José Rogério Cruz e Tucci assevera que "a identificação de parte em senso substancial, como sujeito da lide, é de todo espúria ao sistema de direito processual civil. A denominação parte em sentido substancial, quando não guarda coincidência com a parte que atua no processo, é apenas um terceiro" (Limites subjetivos da eficácia da sentença e da coisa julgada civil, n.3, p. 29).

${ }^{12}$ De acordo com José Alberto dos Reis, "terceiro contrapõe-se a parte; é terceiro em relação a um processo pendente quem não figura nele como parte (conceito negativo)" (Intervenção de terceiros, p. 05).
} 
terceiros todas as pessoas que não são partes no processo ${ }^{13}$. Por esse raciocínio, para que a pessoa possa ser definida como terceiro, é necessário que todos os elementos que identificam o sujeito como parte não estejam presentes. Para tanto, o terceiro não pode ser sujeito da relação jurídico processual, por não ter ajuizado a ação; não pode ter sido entendido como réu; não pode ter sucedido uma das partes; e não pode ter intervindo no processo anteriormente.

Pondere-se que esse critério, apesar de ser de fácil aplicação no plano prático, não é propriamente técnico e, mais precisamente, técnico-processual, de vez que consiste em conceito negativo, servindo mais para dizer quem não é parte do que para retratar quem é terceiro. Nessa linha, todos aqueles que não litigam em determinado processo são considerados terceiros, o que evidencia um conceito extremamente vago, indeterminado e incerto, pois nesse universo existem pessoas que não têm qualquer vínculo ou interesse que pudesse conferir algum liame com a demanda.

Dessa forma, ao buscar tal conceituação, parece-nos necessário acrescer a essas perspectivas negativas elemento afirmativo que se marque como ligação ao processo, por não ser possível entender como terceiros, no plano processual, as pessoas totalmente indiferentes ao litígio. Para que seja admissível a intervenção de alguém no processo, portanto, é necessário que possua interesse jurídico ${ }^{14}$. Se assim não fosse, seria possível a todos intervir em qualquer processo judicial, de maneira indistinta, mesmo sem ter vínculo com o objeto litigioso ${ }^{15}$, o que seria incoerente. Dessa forma, é imprescindível que tenham efetivo interesse jurídico ${ }^{16}$, que se marca pela possibilidade de sua esfera jurídica ser, de algum modo, afetada pelo que se passa no processo.

\footnotetext{
${ }^{13}$ Nesse sentido, Cássio Scarpinella Bueno, ao buscar diferenciar parte de terceiro e conferir um critério útil, afirma que se parte é "quem pede e contra quem se pede alguma espécie de tutela jurisdicional" e "terceiro todo aquele que não pede ou contra nada se pede em juízo. Parte são não-terceiros; terceiros são todos os que não são partes. O conceito de parte, nestas condições, é obtido pela negação de quem seja terceiro e viceversa" (Partes e terceiros no processo civil brasileiro, p. 2-3).

${ }^{14}$ Com propriedade, Athos Gusmão Carneiro diz que o terceiro é apenas aquele atingido na esfera jurídica e que "ostenta interesse jurídico direto e imediato na causa" (Intervenção de terceiros, n. 23.2, p. 70-72).

${ }^{15}$ Sobre a questão, José Rogério Cruz e Tucci destaca que "para que a sentença possa produzir efeitos em relação à situação jurídica do terceiro é necessária a existência de um vínculo jurídico entre duas relações" e conclui que "não basta que a decisão interesse de qualquer modo à esfera jurídico-patrimonial do terceiro (titular de um interesse de fato), mas deve incidir sobre um direito subjetivo deste" (Limites subjetivos da eficácia da sentença e da coisa julgada civil, n.19.2, p. 161).

${ }^{16}$ Segundo Moacyr Amaral Santos, terceiros "são pessoas estranhas à relação de direito material deduzida em juízo e estranhas à relação processual já constituída, mas que, sujeitos de uma relação de direito material que àquela se liga intimamente, intervêm no processo sobre a mesma relação, a fim de defender interesse próprio" (Primeiras linhas de direito processual civil, p. 18).
} 
O terceiro, por outro lado, ao integrar um dos polos da lide, assumirá a qualidade de parte $^{17}$, descaracterizando-se e passando a ser verdadeira parte da demanda, com os deveres, poderes e ônus inerentes à sua posição processual.

Assim, pode-se afirmar que terceiro é aquele que não é parte na relação processual originária e possui interesse jurídico na demanda pendente, por força de a decisão poder afetá-lo de algum modo, causando-lhe benefício ou prejuízo. Por essa razão, o sistema admite que ingresse no processo, voluntariamente ou de modo forçado.

2.3. Dos terceiros e admissibilidade da intervenção no processo. Para abordar o interesse do terceiro e o cabimento de sua intervenção no processo, torna-se necessário verificar se pode haver repercussão da decisão proferida entre as partes em relação a esses terceiros. Em razão do objetivo do presente estudo, analisaremos brevemente esses reflexos, visando apenas delimitar a questão e examinar a situação do terceiro, no que tange às opções que lhe são dadas.

Diante da complexidade das relações jurídicas entre as pessoas, quem não é parte na demanda pode eventualmente ter vínculo com o objeto da causa, apto a produzir efeitos e com potencial para atingir seus direitos e interesses. A depender da relação jurídica por ele mantida, admite-se a intervenção do terceiro no processo.

No direito brasileiro, os efeitos produzidos pelas decisões judiciais restringem-se apenas às partes, dado que é necessário respeitar os princípios do devido processo legal, do contraditório, da ampla defesa e da inafastabilidade da prestação da tutela jurisdicional (art. $5^{\circ}, \mathrm{XXXV}, \mathrm{LIV}$ e $\mathrm{LV}$, da CF ${ }^{18}$. Em razão disso, não se admite, em regra, a extensão dos limites subjetivos da coisa julgada a terceiros.

\footnotetext{
${ }^{17}$ De acordo com Athos Gusmão Carneiro, terceiro só é terceiro até intervir no processo, pois, "pela intervenção, o terceiro torna-se parte (ou coadjuvante da parte) no processo pendente" (Intervenção de terceiros, p. 72).

${ }^{18}$ Cf. Eduardo Talamini, ao ressaltar que, se assim não fosse, "estaria sendo vedado o acesso à justiça ao terceiro, caso se lhe estendesse a coisa julgada formada em processo alheio. Depois, isso implicaria privação de bens sem o devido processo legal. Haveria ainda a frustração da garantia do contraditório: de nada adiantaria assegurar o contraditório e a ampla defesa a todos os que participam de processos e, ao mesmo tempo, impor como definitivo o resultado do processo àqueles que dele não puderam participar" (Coisa julgada e sua revisão, p. 96).
} 
Essa limitação da coisa julgada às partes tem inspiração romana ${ }^{19}$ e, entre nós, está regulada no art. 472 do Código de Processo Civil, segundo o qual "a sentença faz coisa julgada às partes entre as quais é dada, não beneficiando, nem prejudicando terceiros. Nas causas relativas ao estado de pessoa, se houverem sido citados no processo, em litisconsórcio necessário, todos os interessados, a sentença produz coisa julgada em relação a terceiros".

As partes são os destinatários imediatos dos efeitos do provimento jurisdicional ${ }^{20}$. Admite-se, no entanto, que os terceiros possam sofrer os efeitos e a influência de uma decisão ${ }^{21}$, porém isso só se dá em caráter excepcional no sistema jurídico brasileiro ${ }^{22}$. Assim, para efeitos de subsunção à coisa julgada, necessário identificar qual sujeito é parte na posição assumida no processo e não na relação jurídico-material.

Pondere-se que, uma vez admitida a intervenção do terceiro no processo, ele passa a ser considerado parte, ainda que de uma demanda secundária, e pode ser atingido, portanto, pelos efeitos da decisão judicial, em razão de participar do processo de maneira ampla para a formação do convencimento do julgador. Dessa maneira, o terceiro, no que tange ao abordado nesse capítulo, não é aquele que interveio no processo e tornou-se parte, mas o que efetivamente não participou do processo. Nesse passo, o legislador pátrio seguiu a linha do princípio romano e adotou a coisa julgada restrita aos litigantes participantes do

\footnotetext{
${ }^{19}$ Nesse sentido, Giuseppe Chiovenda afirma que o afastamento de terceiros da submissão à coisa julgada é instituto advindo do direito romano: res inter alios iudicatae nullum aliis praeiundicium faciunt (fr. 7 Dig. de except. Rei iudic. 44, 2); non oportet ex sententia sive iusta sive iniusta pro alio habita alium praegravari (fr. 21 Dig. de his qui notantur inf. 3, 2). Isso decorre da relação processual do direito romano que "é considerada uma relação 'singular', isto é, restrita às partes em causa; no direito primitivo alemão, ao contrário, o juízo é 'universal', prejudica todos os presentes à assembleia judiciária, ou quem quer que tenha notícia da sentença", o que explica a multiplicação, no direito alemão, dos meios de defesa para terceiros inexistentes no direito romano (Instituições de direito processual civil, v. 1, n. 133, p. 414-415).

${ }^{20}$ Cássio Scarpinella Bueno diz que a identificação da pessoa como parte ou terceiro é que viabiliza a distinção entre quem estará sujeito “à coisa julgada e quem estará sujeito, apenas e tão-somente, aos efeitos da sentença ou, mais amplamente, aos efeitos de qualquer decisão jurisdicional" (Partes e terceiros no processo civil brasileiro, p. 15-16).

${ }^{21}$ Enrico Tullio Liebman já ressaltava que os efeitos das decisões atingiam eventualmente o terceiro, afirmando que "la regola fondamentale, che limita alle parti l'autorità dela cosa giudicata, tutora pienamente valida, risale ao diritto romano: Res inter alios iudicata tertio non nocet. Ma non esaurisce il problema dela situazione dei terzi di fronte alla sentenza, perché nella vita reale i rapporti tra le persone interferiscono in vario modo tra loro e la sentenza può essere indirettamente relevante anche per i terzi" (Manuale de diritto processuale civile, p. 169).

${ }^{22}$ Cf. Cândido Rangel Dinamarco, ao admitir que, apesar de o art. 472 do Código de Processo Civil apresentar-se em termos aparentemente rígidos, "a realidade mostra que as coisas não se passam precisamente assim e o próprio art. 472 oferece uma primeira abertura para a mitigação da aparente rigidez" (Instituições de direito processual civil, v. III, p. 318).
} 
contraditório, de maneira a impedir que os efeitos da decisão imutável atingissem os interesses de terceiro.

Nessa linha, cumpre, ainda, distinguir, entre aqueles que não ostentam a qualidade de parte, duas categorias: a dos terceiros juridicamente indiferentes e a dos terceiros juridicamente interessados ${ }^{23}$, conforme o que adiante especificaremos.

Considera-se que o terceiro é juridicamente indiferente em relação à matéria debatida na demanda se puder sofrer com a decisão prejuízo unicamente fático, não lhe atingindo a esfera jurídica. A esses, a intervenção não é admitida.

Assim, os terceiros que só tiverem interesse fático na decisão não têm propriamente interesse na demanda, dado que a decisão a ser proferida não lhes trará prejuízo ou benefício jurídico. Saliente-se que o art. 472 do texto processual deve ser interpretado, no que tange a benefício e a prejuízo, como benefício e prejuízo estritamente jurídicos.

Na hipótese de a repercussão da demanda ser apenas sentimental ou moral, da mesma forma, o terceiro será também juridicamente indiferente, tornando-se inadmissível sua intervenção. O mesmo ocorre, via de regra, com aquele que detém interesse econômico $^{24}$ ou institucional ${ }^{25}$, por nenhum desses se confundir com o interesse jurídico ${ }^{26}$.

\footnotetext{
${ }^{23}$ V. José Rogério Cruz e Tucci, ao reportar-se à classificação de Emilio Betti em três distintas categorias: terceiros juridicamente indiferentes; terceiros juridicamente interessados, não sujeitos à exceção de coisa julgada; e terceiros juridicamente interessados, sujeitos à exceção de coisa julgada, acrescenta que essa última categoria é criticada por Francesco Carnelutti, pois "os terceiros juridicamente interessados, sujeitos à exceção de coisa julgada, são, na verdade, sujeitos da relação de direito material e, portanto, são a própria parte (em sentido material)" (Limites subjetivos da eficácia da sentença e da coisa julgada civil, n.19.2, p. 62-69). Entendemos que apenas as duas primeiras categorias podem ser consideradas, em virtude de não ser possível confundir a posição de terceiro com a de parte, sendo que a coisa julgada não vincula aquele, havendo mera eficácia reflexa enquanto for terceiro processualmente.

${ }^{24}$ Eduardo Talamini aponta, ao exemplificar, para a situação em que "o credor de uma das partes que vê o patrimônio dela diminuir com a sucumbência - o que amplia as chances de insucesso na satisfação de seu crédito" (Coisa julgada e sua revisão, p. 98).

${ }^{25}$ É o que sucede, por exemplo, com a Ordem dos Advogados do Brasil, de vez que "o interesse institucional, não obstante encerre também interesse jurídico para a propositura da ação coletiva, não enseja a intervenção ad adjuvandum em processo inter partes" (STJ, REsp 821.586/PR, Rel. Min. LUIZ FUX, 1ª Turma, J 07/10/2008). O mesmo ocorre com o Ministério Público que, "no exercício das suas funções institucionais, não é titular de interesse jurídico assim qualificado. Cumpre-lhe, por força da Constituição (art. 127), tutelar a ordem jurídica, o sistema democrático e os interesses sociais, ou seja, o interesse público genericamente considerado, razão pela qual a sua intervenção em processo de que não é parte se dá, não como assistente de um dos litigantes, mas pela forma própria e peculiar de custos legis (art. 82 do CPC)" (STJ, REsp 724.507/PR, Rel. Min. TEORI ALBINO ZAVASCKI, $1^{\text {a }}$ Turma, J 21/09/2006).
} 
De outro lado, os terceiros que ostentam interesse jurídico direto e imediato na causa, por guardarem relação jurídica com a situação discutida no processo, são os considerados juridicamente interessados. São eles atingidos em sua esfera jurídica, de modo que podem atacar a decisão, tendo para tanto legitimidade e interesse ${ }^{27}$. Não se trata, pois, de mero interesse de fato, mas jurídico, distinguindo-se, assim, dos terceiros juridicamente indiferentes.

Assim, caso haja repercussão que atinja os interesses do terceiro, se ele tiver relação jurídica com a situação debatida, acaba por possuir interesse e legitimidade para agir em juízo, de forma que poderá intervir e participar do processo ${ }^{28}$. Em contrapartida, as garantias do devido processo legal e do contraditório lhe devem ser amplamente asseguradas para que ele não seja surpreendido e até mesmo não seja prejudicado pelo que for decidido.

Presente o interesse jurídico, o terceiro pode postular seu ingresso no processo ou ser chamado a integrá-lo. Assim, na hipótese de ser admitida a aplicação do instituto, os terceiros estranhos à relação processual principal ingressam na demanda - adquirindo, dessa forma, condição de parte na relação processual incidental - e ficam vinculados à decisão e à coisa julgada.

\footnotetext{
${ }^{26}$ V. Athos Gusmão Carneiro, ao exemplificar algumas hipóteses: "uma separação judicial é suscetível de afetar emocionalmente parentes próximos dos cônjuges desavindos; a ação de execução promovida contra um devedor poderá prejudicar a perspectiva de adimplemento de parte de outros credores". Concluiu que nessas hipóteses "a repercussão não ultrapassa o plano dos fatos, não atingindo a esfera jurídica do parente ou do credor" (Intervenção de terceiros, n. 23.2, p. 71). Dessa maneira, falta-lhes interesse jurídico, não podendo, por serem terceiros juridicamente indiferentes, intervir no processo.

${ }^{27}$ V. Athos Gusmão Carneiro, ao exemplificar algumas hipóteses: ação de despejo do locador contra o locatário poderá provocar a resilição da sublocação; ação de indenização em face do contratante inadimplente poderá repercutir na esfera patrimonial do fiador; ação de indenização em face do causador de acidente de trânsito poderá atingir o segurador de responsabilidade civil; ação de anulação de testamento movida em face de um legatário poderá refletir no quinhão hereditário dos outros herdeiros; ação reivindicatória promovida por apenas um dos condôminos contra o esbulhador poderá atingir os demais condôminos proprietários do imóvel (Intervenção de terceiros, n. 23.2, p. 71). Acrescente-se, ainda, a hipótese em que é movida ação voltada à anulação de ato societário, de modo que o sócio que não é parte na demanda pode intervir, em razão de a sentença produzir efeitos que atingirá a todos (v. José Rogério Cruz e Tucci, Limites subjetivos da eficácia da sentença e da coisa julgada civil, n. 24.4.2, p. 239).

${ }^{28}$ Diversamente, Paulo Palmeira aponta que se admite, no direito francês, a intervenção acessória, bastando a justificativa de um legítimo interesse para autorizar a intervenção, que pode ser de ordem pecuniária ou moral, bem como indireta, futura ou ainda eventual (Da intervenção de terceiros nos principais sistemas legislativos: da oposição, p. 10-11).
} 
2.4. Da modalidade e iniciativa de intervenção de terceiros. É certo que em função da natureza do interesse jurídico do terceiro e do seu grau de intensidade surgem posições diferentes a serem assumidas no processo, não havendo, portanto, apenas um tipo de intervenção. Existem, ao contrário, diversos tipos que partem de pressupostos também diferenciados e, pois, terão direitos e ônus diferentes em sua atuação.

Nesse sentido, há figura que exclui a parte originária (nomeação à autoria), outras que a elas se contrapõem (oposição e denunciação da lide), outras, ainda, que com elas demandam (assistência e chamamento ao processo).

Da mesma forma, há distinções quanto à iniciativa da intervenção, que nem sempre é voluntária, partindo da iniciativa do terceiro. Muitas vezes, ela é provocada pelo reclamo de alguma das partes, que o faz com espeque na lei ${ }^{29}$.

Assim, intervenção voluntária é espontânea. Constitui-se numa faculdade conferida ao terceiro que tem o seu interesse jurídico envolvido no processo pendente e resolve, por si só, dele participar para não correr risco de ser atingido reflexamente por aquela decisão. Tal se dá na assistência e na oposição. Por meio dessas intervenções, permite-se que o terceiro ingresse no feito sem ser provocado a atuar, com o objetivo de evitar que a decisão judicial lhe seja prejudicial ou de buscar que o resultado the seja favorável no processo em que as partes contendem. Nenhuma dessas figuras é obrigatória, não ficando o processo maculado se o terceiro dele não participar.

Já a intervenção provocada é a forçada: o terceiro é chamado ao processo por iniciativa de uma das partes, como ocorre na nomeação à autoria, na denunciação da lide e no chamamento ao processo. O réu pode provocar essa intervenção em todas essas figuras, ao passo que o autor apenas pode fazê-lo na denunciação. Uma vez deferida a intervenção,

\footnotetext{
${ }^{29}$ Paulo Palmeira faz interessante estudo sobre intervenção de terceiros no direito estrangeiro. Aponta, no direito francês, para a existência da intervenção voluntária - apesar da ausência de texto legal concernente ao direito de intervir em primeira instância - e forçada - prevista sob a forma de demanda incidente em garantia; no direito italiano, admite-se a intervenção voluntária (art. 105) - principal, adesiva e litisconsorcial - e a coacta a requerimento da parte (art. 106) e por ordem do juiz (art. 107) - subordinadas a pressupostos distintos: a comunhão da causa e a pretensão de garantia; no direito alemão, distingue-se com precisão e clareza as várias figuras da intervenção nos parágrafos 64 (oposição), 66 (assistência simples), 69 (assistência qualificada ou litisconsorcial), 72 (chamamento à autoria), 75 (denunciação da lide ao terceiro pendente) e 76 (nomeação à autoria)" (Da intervenção de terceiros nos principais sistemas legislativos: da oposição, p. 09$50)$.
} 
quem foi trazido ao processo a ele fica vinculado, de modo que terá ônus a serem cumpridos e ficará sujeito aos efeitos da decisão, atue concretamente ou não. Torna-se, diante da ordem judicial, parte do processo.

Tanto a intervenção voluntária quanto a provocada são meios conferidos pelo legislador processual para vincular os terceiros, direta ou indiretamente ligados ao que se discute na demanda, à coisa julgada. Essas modalidades têm a finalidade de favorecer aquele que chama o terceiro, por vários motivos: seja em razão de a intervenção ter potencial de colocá-lo numa situação processual melhor que aquela em que se encontra; seja porque o terceiro vai ficar no seu lugar no processo; seja, ainda, porque o terceiro com ele vai dividir os ônus da derrota. Com isso, poder-se-á corrigir o polo passivo da demanda (nomeação à autoria), responsabilizar o terceiro pela garantia do negócio jurídico no caso de sucumbimento (denunciação da lide) ou chamar terceiro para definir a responsabilidade dos co-obrigados na mesma sentença e viabilizar a cobrança dos demais na proporção que lhes couber (chamamento ao processo).

Em todas as modalidades de intervenção, caberá ao juiz analisar se estão presentes os requisitos necessários para que ela possa ter lugar, a fim de deferir ou rejeitar o pedido de intervenção. Não basta, pois, o simples ingresso do terceiro na intervenção voluntária ou o pedido das partes, na provocada.

Do mesmo modo que cabe ao autor posicionar-se como tal e colocar como réu quem ele considera que o seja, também na intervenção o problema é das partes. Não cabe ao juiz determinar, de ofício, a participação de terceiros ${ }^{30}$, exceto na hipótese de litisconsórcio necessário, nos limites do art. 47 do Código de Processo Civil, quiçá porque o litisconsórcio necessário é alguém que está ligado ao que se discute no processo e no feito deveria estar desde o início. Não pode o juiz, portanto, determinar que terceiro ingresse na demanda, em vista de entender que ele tem direito ou é responsável pelo cumprimento da obrigação. $\mathrm{O}$ julgador deve limitar-se a decidir nos limites em que a ação foi proposta, de vez que não lhe cabe sequer salvaguardar a utilidade da tutela

\footnotetext{
${ }^{30}$ Diferentemente, existe, no direito italiano, a intervenção "per ordine del giudice" (art. 107: "il giudice quando ritiene oportuno che il processo si svolga in confronto de um terzo al qual ela causa è comune, ne ordina intervento"), por meio da qual ao magistrado é facultado determinar a presença de um terceiro, independentemente da vontade das partes, que poderão apenas se irresignar e demonstrar a inconveniência da intervenção.
} 
jurisdicional. Por exemplo, se o autor não incluiu outros réus no polo passivo, não cabe ao juiz trazê-los; se não ajuizou a ação em face de quem tem legitimidade, o juiz deve, simplesmente, extinguir o processo, ressalvada a hipótese de litisconsórcio necessário.

2.5. Do tratamento legal da intervenção de terceiros. $O$ legislador brasileiro denominou de intervenção de terceiros a oposição, a nomeação à autoria, a denunciação da lide e o chamamento ao processo, dispondo sobre os pressupostos e o procedimento destes institutos nos arts. 56 a 80 do Código de Processo Civil.

Além dessas, a assistência também é, por muitos ${ }^{31}$, considerada intervenção de terceiros, em que pese esteja disciplinada em outro capítulo, sendo tratada nos arts. 50 a 55 do texto processual. Nega-se essa natureza ao instituto porque o assistente não tem interesse próprio, mas atua para que o assistido logre êxito no processo. Há quem considere, ainda, que os embargos de terceiro e a intervenção de credores na execução são modalidades de intervenção de terceiros.

A figura do amicus curiae não possui previsão legal expressa no atual sistema processual $^{32}$, porém, por influência do direito norte-americano e inglês, tem seduzido os doutrinadores e ganhado espaço na jurisprudência, a fim de também ser aplicada no direito brasileiro, na busca de medidas que proporcionem o alcance de uma prestação jurisdicional justa e eficaz ${ }^{33}$.

\footnotetext{
${ }^{31}$ V. Daniel Daniel Ustárroz, A Intervenção de terceiros no processo civil brasileiro, p. 35.

${ }^{32}$ Em sentido contrário, Gisele Santos Fernandes Góes afirma que o "diploma processual civil agasalha a possibilidade do amicus curiae, como se depreende dos arts. 339 e 341, I" (Amicus curiae e sua função nos processos objetivos. Necessidade de universalização do instituto para outras demandas, p. 273). A afirmação não nos parece correta, dado que os referidos dispositivos estão tratados no capítulo "Das provas" e não introduzem nova modalidade de intervenção de terceiros. Assim, não se pode, a partir deles, concluir-se que a figura do amicus curiae está regulada.

${ }^{33}$ Apesar da falta de dispositivo legal expresso a tratar do amicus curiae, o Supremo Tribunal Federal já tem admitido a sua ampla aplicação em ações diretas de inconstitucionalidade (art. $7^{\circ}$, § $2^{\circ}$, da Lei 9.868/99) e arguições de descumprimento de preceito fundamental. Há apenas previsões esparsas sobre a intervenção do amicus curiae no direito brasileiro, como sucede no art. $23, \S 1^{\circ}$, da Resolução 390/04 do Conselho da Justiça Federal; no art. 31 da Lei Federal n. 6.375/76, que impôs a intervenção da Comissão de Valores Mobiliários nos processos que discutem matéria objeto de competência dessa autarquia; no art. 89 da Lei Federal n. 8.884/94 (Lei Antitruste), ao impor a intimação do Conselho Administrativo de Defesa Econômica nos processos em que se discutem questões ligadas ao direito de concorrência; no art. $6^{\circ}$ da Lei $9.882 / 99$, que prevê a possibilidade, em ação de arguição de descumprimento de preceito fundamental, de ouvir pessoas com experiência e autoridade na matéria do ato questionado.
} 
Amicus curiae é terceiro, porém não pode ser enquadrado numa das figuras de intervenção de terceiro reguladas no processo civil brasileiro ${ }^{34}$. Ao tratar da questão, CÁSSIO SCARPINELLA BUENO ponderou que a circunstância de ser terceiro "não aproxima, por si só, os amici daquelas outras figuras. Apenas revelam um traço comum"

Pondere-se, por fim, que o ingresso de outros sujeitos, que não são partes originárias, no processo, nem sempre constitui intervenção de terceiro. Nesse sentido, a substituição da parte no curso do processo por força de lei (art. 41 CPC) - só ocorre se o titular de direito material estiver ausente do processo - não implica intervenção de terceiro, assim como o ingresso de litisconsortes necessários (art. 47 do CPC), dado que esses já deveriam estar no polo passivo, em virtude de o juiz dever decidir a lide de modo uniforme para todos.

\footnotetext{
${ }^{34}$ Nesse sentido, Clito Fornaciari Júnior posicionou-se, ao dizer que ele "nada tem com intervenção de terceiros, de vez que se coloca como alguém (pessoa física, órgão ou entidade especializada) que é chamado a manifestar-se, sem ter interesse na solução da contenda e no conflito que nela se coloca. É um conselheiro, digamos assim. Seria algo como um testemunho qualificado pela especialidade, sem se sujeitar, evidentemente, aos efeitos da decisão" (www.jurisdrops.blogspot.com.br, postagem de 29/06/2010). Nessa linha já entendeu o Superior Tribunal de Justiça (RESP 1.205.946/SP, Rel. Min. BENEDITO GONÇALVES, DJE 12/08/2011).

${ }_{35}$ Apesar de considerar o amicus curiae terceiro, afirma que a ausência de um interesse jurídico é o grande traço distintivo do amicus curiae com as demais figuras catalogadas como intervenção de terceiros. Acrescenta que ser terceiro não "significa que deva necessariamente assumir aquelas específicas modalidades de terceiro que o nosso CPC conhece" (Amicus Curiae no Processo Civil Brasileiro: um terceiro enigmático, p. 128 e 435$)$.
} 


\section{DOS INSTITUTOS AFINS À DENUNCIAÇÃO DA LIDE}

3.1. Da razão de se comparar. Diante das particularidades de cada espécie de intervenção de terceiro - aqui se considerando também a assistência, embora tratada em capítulo diverso do Código - relevante destacar os traços principais de cada uma delas, sempre no intuito de distingui-las da denunciação de lide, visando desenhar melhor o perfil desta. Essa exata percepção é necessária, de vez que a comparação evidencia as particularidades e, pois, melhor define o perfil do instituto pesquisado, o que contribui para uma precisa formulação técnica do instituto da denunciação da lide para possibilitar, posteriormente, o desenvolvimento de seu processamento e do que se pode obter como resultado mercê de sua utilização.

Ressalve-se, outrossim, que cada modalidade de intervenção de terceiro tem finalidade e razão de ser próprias, de modo que sua regulamentação não se confunde com as outras, possuindo, ainda, procedimentos distintos. $\mathrm{O}$ único ponto de efetiva afinidade entre os diversos institutos é que todos são modalidades de intervenção de terceiro ${ }^{36}$, ou seja, alguém que não estava no processo e que nele passa a atuar como parte.

\subsection{Da assistência}

3.2.1. Da origem e evolução do instituto. A assistência remonta ao direito romano, no período da extra ordinem cognitio, e surgiu, segundo CELSO AGRÍCOLA BARBI $^{37}$, fundado nas lições de MOACYR LOBO DA COSTA, com o objetivo de impedir que, pelo conluio, dolo ou negligência da parte, a sentença viesse a prejudicar terceiro.

\footnotetext{
${ }^{36}$ Nesse sentido, Antonio Carlos de Araújo Cintra, tratando do tema à luz do Código de Processo Civil de 1939, destaca que cada um dos institutos "tem regulamentação legal própria, inconfundível e inaplicável, ainda que parcialmente, a qualquer dos outros" e conclui existir identidade quanto à "entrada de terceiro no processo pendente entre outras partes" (Do chamamento à autoria, p. 05).

${ }^{37}$ Comentários ao Código de Processo Civil, p. 286.
} 
Entre nós, o instituto, por influência do direito português, foi previsto no Regulamento 737 de 1850 (art. 123 a 125), nos Códigos Estaduais e no Código de Processo Civil de 1939 (art. 93), em dispositivo que, apesar de distinguir a assistência simples da litisconsorcial, recebeu crítica da doutrina ${ }^{38}$, por ser demasiadamente lacônico e falho de clareza. Rezava o texto que, "quando a sentença houver de influir na relação jurídica entre qualquer das partes e terceiro, este poderá intervir no processo como assistente, equiparado ao litisconsorte".

O Código de Processo Civil de 1973 tratou do instituto de maneira mais profunda, disciplinando-o fora do capítulo da "Intervenção de terceiros", ao regulá-lo nos arts. 50 a 55, no capítulo "Do litisconsórcio e da assistência"39. Preocupou-se o legislador em disciplinar separadamente a figura da assistência simples da litisconsorcial, centrando a primeira no "interesse jurídico em que a sentença seja favorável a uma delas" e a segunda na possibilidade de a decisão "influir na relação jurídica entre ele e o adversário do assistido".

Ao explicar a razão do posicionamento da assistência em outro capítulo, ARRUDA ALVIM afirma que, nas outras modalidades de intervenção de terceiros, "há sempre uma pretensão em jogo, ou seja a afirmação de um direito (pretensão), mesmo na nomeação à autoria, em relação àquele que ingressa no processo", diferentemente do que se dá na assistência simples ${ }^{40}$, em razão de a sentença não atingi-lo, por não manter com ele relação jurídica.

No mesmo sentido, CLITO FORNACIARI JÚNIOR diz, ao explicar o motivo de o instituto estar disciplinado em outro capítulo, que "apenas o assistente não deduz no processo uma pretensão", ao contrário de todos os demais intervenientes que "comparecem para discutir pretensão própria"41.

\footnotetext{
${ }^{38}$ V. Moacyr Amaral Santos, Primeiras linhas de direito processual civil, p. 49-50.

${ }^{39}$ Ovídio Araújo Batista da Silva explica que "assistência é forma típica de intervenção de terceiro, embora o Código, inspirado nas lições de CARNELUTTI - que preferia indicar o assistente como sujeito da ação, em oposição à parte principal que seria sujeito da lide -, não a tenha incluído no capítulo dedicado à intervenção de terceiros, preferindo tratá-lo ao lado do litisconsórcio, como se o assistente fosse uma parte secundária, ou acessória", o que, todavia, não é correto, pois o assistente é terceiro (Comentários ao Código de Processo Civil, p. 256).

${ }^{40}$ Código de processo civil comentado, v. III, p. 5-6.

${ }^{41}$ Reconhecimento jurídico do pedido, p. 30.
} 
Diante desse posicionamento legislativo, conclui-se que o critério legal para definir-se a intervenção de terceiros é a existência de interesse próprio, que se marca com o exercício de uma pretensão, afirmada ou resistida.

3.2.2. Da noção e importância do instituto. A assistência é modalidade de intervenção de terceiros ad coadjuvandum ${ }^{42}$, visando o assistente ajudar uma das partes, por ser titular "de uma relação jurídica conexa ou dependente da res in judicium deducta" $^{\text {,3 }}$; possui, portanto, da mesma forma que as demais figuras de intervenção de terceiros, efetivo interesse jurídico, que não se restringe apenas ao econômico ${ }^{44}$.

Cuida-se de modalidade de intervenção voluntária no processo, procurando o assistente, ao ajudar o assistido, evitar decisão que lhe possa causar reflexos jurídicos negativos. Apesar de seu ingresso no feito, não se ampliará o objeto do processo, até porque sua atuação é apenas protetiva e não formula pretensão própria; isso porque sua característica é a indiferença do objeto do processo quando de seu ingresso na relação jurídica.

Em vista dessa natureza da assistência, ela pode dar-se em qualquer tipo de procedimento, mesmo no sumário (art. 280 do $\mathrm{CPC}$ ) e em se tratando de mandado de segurança $^{45}$, mas não no Juizado Especial, que, por opção do legislador, não admite qualquer forma de intervenção de terceiros, referindo-se inclusive à assistência de modo expresso (art. 10 da Lei 9.099/95). Na execução, não é permitida a assistência ${ }^{46}$, por não haver atividade cognitiva, mas é cabível, nos embargos do devedor, em vista de o assistente poder auxiliar o denunciante.

\footnotetext{
${ }^{42}$ Fredie Didier Júnior, Curso de Direito Processual Civil, v. 1, p. 337.

${ }^{43}$ Cândio Rangel Dinamarco, Intervenção de terceiros, p. 37.

${ }^{44}$ Athos Gusmão Carneiro diz que "não é qualquer interesse que autoriza um terceiro a intervir no processo em favor de uma das partes, mas sim apenas interesse jurídico. O interesse, v. g., meramente afetivo, ou meramente econômico, não faculta a assistência" (Intervenção de terceiros, p. 190).

${ }^{45}$ Cf. José Manoel de Arruda Alvim Netto, Araken de Assis e Eduardo Arruda Alvim, que, todavia, ressalvam haver decisões em sentido contrário no Superior Tribunal de Justiça (Comentários ao código de processo civil, p. 115).

${ }^{46}$ A questão é divergente, havendo decisão em sentido contrário (STJ, REsp n. 146.124/MG, $1^{\text {a }}$ Turma, Rel. Min. HUMBERTO GOMES DE BARROS, J. 09/10/1997).
} 
Admite-se a assistência em qualquer grau de jurisdição, assumindo o assistente o processo no estado em que estiver (art. 50, parágrafo único, do $\mathrm{CPC}$ ). Essa questão é extremamente relevante, devendo o assistente avaliar, antes de ingressar no processo, se é realmente viável fazê-lo naquele momento, pois não será admissível retroceder para a prática de atos que, pela marcha processual, já foram superados ou atingidos pela preclusão.

Diante desse quadro, o juiz decidirá a relação jurídica envolvendo o autor e o réu, não ficando o assistente sujeito à coisa julgada - até porque não sustenta qualquer pretensão sua no processo - mas ficando impedido de rediscutir a justiça da decisão (art. 55 do $\mathrm{CPC})^{47}$, vinculando-se, assim, a ela.

Na classificação, há duas espécies de assistência: a simples e a litisconsorcial, que se distinguem em razão dos interesses perseguidos pelo assistente ${ }^{48}$.

$\mathrm{Na}$ assistência simples, também conhecida como adesiva, o assistente atuará como "auxiliar da parte principal, exercerá os mesmo poderes e sujeitar-se-á aos mesmos ônus processuais que o assistido" (art. 52 do CPC). Pode-se dizer que, pela distinção de ATHOS GUSMÃO CARNEIRO, o assistente possui interesse, mas em intensidade moderada, já que o direito de que é titular não está diretamente em disputa.

O assistente é titular de relação jurídica conexa àquela debatida, possivelmente afetada pela decisão da relação jurídica de direito, que não lhe diz respeito diretamente. Desse modo, auxiliará e fiscalizará a conduta processual do assistido, com quem tem relação, até porque lhe foram conferidos deveres e ônus, "a fim de prevenir possível desídia da parte a que presta auxílio, bem como impedir que o eventual conluio dela com o seu adversário ponha em perigo a sorte da demanda", devendo essas funções ser desempenhadas harmonicamente ${ }^{49}$.

\footnotetext{
${ }^{47}$ Moacyr Amaral Santos expõe que "no que tange ao assistente, nada a sentença decide, mesmo porque ele nada pediu, nem poderia pedir, nem contra ele nada foi pedido. Mas, em seus efeitos, a sentença pode atingir o interesse jurídico do assistente e até mesmo, no caso de assistência litisconconsorcial, afetar a relação jurídica entre o assistente e o adversário do assistido. Desses efeitos, em princípio, o assistente não poderá fugir, salvo se tiver ação para desfazê-los ou reduzi-los" (Primeiras linhas de direito processual civil, v. 2, p. 57).

${ }^{48}$ Athos Gusmão Carneiro considera que a "intensidade" dos interesses é que distingue as espécies (Intervenção de terceiro, p. 202).

${ }^{49}$ Cf. Ovídio Araújo Batista da Silva, Comentários ao Código de Processo Civil, p. 257-258. 
A assistência será litisconsorcial ou qualificada, quando "a sentença houver de influir na relação jurídica entre ele e o adversário do assistido" (art. 54 do CPC). Não se trata propriamente de litisconsorte, que poderia ficar subentendido por força da denominação e de estar a assistência inserida dentro do capítulo em que está regulada, até porque "não traz ao processo demanda alguma para ser julgada, nem em face dele foi proposta qualquer demanda a ser julgada na sentença de mérito" ${ }^{, 50}$.

Nesse tipo de assistência, haverá, na causa, interesse jurídico imediato do assistido e a relação jurídica discutida é aquela em que ele se afirma titular. Assim, o assistente é direta e imediatamente vinculado à relação jurídica material deduzida em juízo, de vez que guarda vínculo com o adversário do assistido. Em vista disso, reconhece-se que o assistente litisconsorcial possui mais poderes que o assistente simples, não precisando atuar em absoluta sintonia com o assistido ${ }^{51}$; tem, portanto, liberdade maior que a do assistente simples.

Diante dessas distinções, a eficácia da sentença, na assistência simples, é meramente reflexa ou indireta ${ }^{52}$, diferente do que se dá na assistência litisconsorcial, na qual o assistente é afetado, já que a sua relação jurídica também está sendo julgada ${ }^{53}$.

\subsection{Da oposição}

3.3.1. Da origem e evolução do instituto. A origem da oposição, denominada de hauptintervention $^{54}$, é germânica. No processo germânico-bárbaro, os litígios eram decididos em praça pública, razão pela qual os efeitos da sentença atingiam as partes, todos os que dela participavam e também os que a conheciam ${ }^{55}$. Por consequência, os terceiros

\footnotetext{
${ }^{50}$ Cândido Rangel Dinamarco, Instituições de direito processual civil, v. II, n. 597, p. 391.

51 Cândido Rangel Dinamarco faz oportuna comparação, ao equiparar os poderes mais intensos que são conferidos ao assistente litisconsorcial na relação jurídica processual em relação ao assistente simples, "na medida em que é mais intenso o prejuízo que este pode trazer-lhe" (Litisconsórcio, p. 24-25).

${ }^{52}$ Eduardo Arruda Alvim afirma que "não é a coisa julgada material que atingirá esse terceiro, mas a decisão da lide em sua eficácia natural" (Breves considerações sobre a assistência e o recurso de terceiro prejudicado, p. 184-185).

${ }_{53}$ V., nesse sentido. Cássio Scarpinella Bueno, Partes e terceiros no processo civil brasileiro, p. 139.

${ }^{54} \mathrm{Cf}$. Daniel Ustárroz, A Intervenção de terceiros no processo civil brasileiro, p. 59.

55 Cândido Rangel Dinamarco explica que existia "a indispensabilidade da manifestação do interesse de terceiro ao bem disputado pelas partes, sob pena de sua pretensão ficar definitivamente afastada", por força
} 
que se consideravam senhores do direito ou da coisa, sobre a qual litigavam as partes, deveriam intervir, a fim de reivindicar seu direito incompatível com o dos litigantes, aos quais pretendiam excluir ${ }^{56}$.

No direito canônico e comum, a oposição tornou-se "ação autônoma do terceiro contra ambas as partes" e o direito português recepcionou este modelo e influenciou, posteriormente, o direito brasileiro, em que o instituto foi disciplinado nos arts. $118 \mathrm{e}$ seguintes do Regulamento 737 de 1850, previsto nos códigos estaduais e transplantado para os arts. 102 a 105 do Código de Processo Civil de $1939^{57}$, com o mesmo perfil que guarda hoje.

O instituto está regulado, atualmente, nos arts. 56 a 61 do Código de Processo Civil de 1973 e apresenta, sem alterar sua finalidade e razão de ser, duas formas interventiva (art. 59 do CPC) ou autônoma (art. 60 do CPC) ${ }^{58}$ - dependendo do momento em que é deduzida, em função do estágio do processo. Será interventiva, caso seja apresentada antes de iniciada a audiência de instrução e julgamento ${ }^{59}$, e autônoma, na hipótese de ser deduzida após o início da audiência até ser proferida sentença, que é o momento final para ser deduzida (art. 56 do CPC).

\subsubsection{Da noção e importância do instituto. A oposição interventiva transforma} "a relação primitiva numa nova e única relação processual, de natureza ainda mais complexa" ${ }^{, 60}$, não dando "origem a um novo processo, mas a um mero incidente do processo já pendente" ${ }^{, 61}$. Essa forma de oposição será apensada aos autos principais e correrá simultaneamente com a demanda principal, sendo ambas julgadas pela mesma sentença.

\footnotetext{
da universalidade dos juízos, dado que "o reconhecimento do direito de um dos litigantes excluía as pretensões de todos os demais membros da assembléia", o que, posteriormente, foi atenuado entre os próprios germânicos (Intervenção de terceiros, p. 47-48).

${ }_{56}^{5}$ Moacyr Amaral Santos, Primeiras linhas de direito processual civil, p. 43.

${ }^{57}$ Moacyr Amaral Santos, Primeiras linhas de direito processual civil, p. 43-44.

${ }^{58}$ Cândido Rangel Dinamarco afirma que o "sistema brasileiro contém as duas modalidades", sendo que "a intervenção autônoma, de origem romana, é praticada no processo civil alemão atual; enquanto que a interventiva tem origem germânica e está presente no processo civil italiano" (Instituições de direito processual civil, v. II, p. 384).

${ }^{59}$ Se a oposição for oferecida depois de iniciada a audiência, o juiz poderá suspender até 90 dias o andamento do processo principal, a fim de o processo de oposição alcançar a fase procedimental daquele para o julgamento de ambas as ações ser conjunto. A propósito, Athos Gusmão Carneiro diz que "é medida de economia e simplificação processual" (Intervenção de terceiros, p. 94).

${ }^{60}$ Moacyr Amaral Santos, Primeiras linhas de direito processual civil, p. 45.

${ }^{61}$ Cândido Rangel Dinamarco, Intervenção de terceiros, p. 105.
} 
A oposição autônoma, de outro lado, é um autêntico processo novo, em vista de ser deduzida depois da audiência, e produz efeitos sobre a causa pendente, impondo distribuição por dependência. Relevante destacar que, segundo CÂNDIDO RANGEL DINAMARCO, "apesar da menor intensidade de sua incidência sobre a causa pendente, três pontos dão à oposição autônoma a qualidade de oposição: a) competência funcional do juiz (art. 57); b) a possível suspensão do processo, confiada à prudente apreciação do juiz (art. 60) mas que ele, sempre que entender devida, determinará de ofício; c) a possível unidade de julgamento, numa sentença só (art. 60)"62.

Se o processo já tiver sentença, entretanto, não caberá mais oposição e o terceiro deverá mover ação autônoma em face de quem se saiu vencedor na ação principal, a fim de preservar seus direitos, até por não ser atingido pela coisa julgada formada no processo em que não interveio; perde, assim, as vantagens que essa modalidade lhe poderia conferir, suportando os encargos de ação totalmente autônoma.

A oposição é ação. O opoente, como autor, deverá respeitar os requisitos da petição inicial (art. 57 do CPC), figurando ambas as partes do processo primitivo como réus, em litisconsórcio passivo necessário, não unitário. Ao contrário da denunciação da lide, constitui modalidade de intervenção de terceiro voluntária, por meio da qual o opoente deduz espontaneamente sua pretensão em face do autor e do réu ${ }^{63}$.

Trata-se de uma mera faculdade, outrossim, dado que a sentença proferida na ação entre as partes originárias só faz coisa julgada entre elas (art. 472 do CPC), porém lhe pode ser mais conveniente "uma imediata afirmação de suas pretensões sobre a coisa ou o direito controvertidos entre o autor e o réu" ${ }^{\prime 64}$, aproveitando-se da atividade deles. CÂNDIDO RANGEL DINAMARCO considera, com propriedade, que a lei autoriza o opoente a impugnar o pedido do autor e a pleitear para si a tutela jurisdicional "para evitar um precedente incômodo e para acelerar a tutela jurisdicional”, 65 .

\footnotetext{
${ }^{62}$ Cândido Rangel Dinamarco, Intervenção de terceiros, p. 113.

${ }^{63}$ Daniel Ustárroz afirma que a oposição distingue-se das demais formas de ação de terceiros, em vista de seu regramento ser bastante particular, já que o opoente "deduz pretensão contrária à do autor e à do réu, jamais auxiliando qualquer das partes", dado que "litiga contra ambas" (A intervenção de terceiros no processo civil brasileiro, p. 61).

${ }^{64}$ Cf. Athos Gusmão Carneiro, Intervenção de terceiros, p. 91.

${ }^{65}$ Instituições de direito processual civil, p. 382.
} 
Dessa maneira, a oposição amplia o objeto do litígio, de vez que o opoente traz novas questões para serem conhecidas a fim de amparar sua pretensão. Já relativamente à oposição autônoma, não há que se cogitar de ampliação do objeto do processo, pois ela dá origem a um processo novo.

Cumpre salientar que a oposição é admissível em qualquer rito processual, exceto no procedimento sumário (art. 280 do CPC), sendo vedada também nos Juizados Especiais (art. 10 da Lei 9.099/95). Por sua natureza, é própria de processos de conhecimento, havendo restrição à sua existência na fase de cumprimento de sentença e nas execuções ${ }^{66}$.

Assim, a oposição é importante figura de intervenção de terceiros, especialmente se ela se der antes da audiência de instrução e julgamento ou se for possível sobrestar o andamento do processo principal, a fim de propiciar que ambos caminhem juntos e sejam julgados pela mesma sentença. Está em sintonia com os princípios da economia e da efetividade processual, bem como com os da pacificação social, dado que o julgador decidirá sobre o bem da vida em disputa, envolvendo o autor, o réu e o opoente, o que confere maior estabilidade e segurança jurídica e evita até mesmo decisões conflitantes.

O objetivo da oposição, entretanto, só será alcançado se a sentença for única, julgando, simultaneamente, a pretensão do autor e a do opoente e resolvendo-as de uma só vez, em relação ao mesmo bem que as partes originárias disputam.

Assim sendo, se trazida depois da audiência, a oposição perderá a natureza de intervenção, transformando-se em ação autônoma, razão pela qual essa figura de intervenção de terceiros perde sua relevância, transformando-se numa ação autônoma como qualquer outra; assim sendo, litiga o opoente não como terceiro, mas como autor em face dos litigantes da demanda primitiva ${ }^{67}$.

\footnotetext{
${ }^{66}$ Nessa linha, José Manoel de Arruda Alvim Netto afirma que "a oposição é exercício de ação e, portanto, se insere na temática e campo do processo de conhecimento. Descabe, desta forma, no processo de execução" (Código de processo civil comentado, p. 110).

${ }^{67}$ Nesse sentido, Clito Fornaciari Júnior, diante da atual estrutura do instituto, afirma que "somente deve ser considerada intervenção de terceiro a oposição quando oferecida antes da audiência. Depois desse termo, não teremos propriamente intervenção em processo alheio, mas sim, demanda autônoma contra as partes de um outro processo" (Reconhecimento jurídico do pedido, p. 33).
} 
A oposição, portanto, é a única modalidade de intervenção de terceiro em que o interessado efetivamente move ação em face do autor e do réu, litigando efetivamente contra ambos. Seus interesses não se confundem, pois o opoente deduz pretensão contrária tanto em relação ao requerente como ao requerido. Possui inegável importância histórica e relevante utilidade prática, que atende aos princípios da economia e da efetividade processual.

\subsection{Da nomeação à autoria}

3.4.1. Da origem e evolução do instituto. A raiz da nomeação à autoria encontra-se no direito romano (Constantino $3,19,2)^{68}$, tendo sido prevista nas Ordenações Filipinas e em vários Códigos de Processo Civil estaduais, até ser disciplinada no Código de Processo Civil de 1939. Ressalve-se que, nesse texto processual, só o possuidor era legitimado a fazer a nomeação à autoria e ainda de forma facultativa ${ }^{69}$.

O Código de Processo Civil de 1973 deu tratamento diverso ao instituto, que foi ampliado, a fim de conferir oportunidade de o detentor também fazer uso dessa modalidade de intervenção, conforme se encontra regulado nos arts. 62 a 69, impondo, ainda, ao réu um dever, que não existia no Código anterior.

3.4.2. Da noção e importância do instituto. Trata-se de figura de intervenção de terceiro obrigatória, constituindo ato exclusivo do réu, que deve atuar com lealdade e boafé, de vez que este, se deixar de fazer a nomeação ou se nomear pessoa diversa daquela que deveria nomear, responderá por perdas e danos (art. 69 do CPC).

A nomeação deve ser feita pelo réu, no prazo para a defesa, devendo o juiz, se deferir o pedido, suspender o processo e determinar manifestação do autor sobre o acolhimento ou não da nomeação (art. 64 do CPC). Se a recusar ou o nomeado negar essa qualidade, a nomeação ficará sem efeito e a ação prosseguirá em face do nomeante, que

${ }^{68}$ Cf. Moacyr Amaral Santos, Primeiras linhas de direito processual civil, p. 19.

${ }^{69}$ Cf. Celso Agrícola Barbi, Comentários ao Código de Processo Civil, p. 321-323. 
terá novo prazo para contestar. Na hipótese de o autor aceitar e o nomeado também, o processo continuará contra este último (arts. 65 a 67 do CPC).

O objetivo do instituto é corrigir o polo passivo da demanda, trazendo o efetivamente legitimado ao feito para responder ao pedido do autor. Busca-se, pois, a exclusão desse réu do polo passivo da demanda, que passa a ser ocupada pelo nomeado; este, por sua vez, reconhece sua legitimidade em vista de a ação ter sido indevidamente promovida em face de possuidor direto ou detentor da coisa objeto da demanda. Não implicará, todavia, ampliação objetiva ou subjetiva do processo $^{70}$, mas apenas alteração do réu, de modo que o nomeado, se aceitar a qualidade que lhe é atribuída, responderá aos termos da ação antes intentada.

CÂNDIDO RANGEL DINAMARCO conclui que "a utilidade da nomeação à autoria consiste em antecipar soluções para a questão da legitimidade passiva mediante um incidente razoavelmente simples em que o autor, alertado, tem oportunidade de ratificar a mira da demanda proposta",71.

De maneira também precisa, VICENTE GRECO FILHO afirma que a nomeação à autoria (nominatio auctoris) visa à busca da pertinência subjetiva da ação no pólo passivo da relação processual, porque é instituto destinado à substituição do réu, parte ilegítima, por outra pessoa revestida de legitimação" ${ }^{\text {72 }}$.

Já OVÍDIO ARAÚJO BATISTA DA SILVA considera ser a nomeação mecanismo de superação de eventual dificuldade fática encontrada pelo demandante para identificar com segurança o verdadeiro legitimado passivo, evitando-se "que o autor veja sua demanda repelida, salvando a ação erroneamente dirigida contra quem não seja o legitimado passivo",73.

\footnotetext{
${ }^{70}$ V. Fredie Didier Júnior, Curso de Direito Processual Civil, v. 1, p. 348.

${ }^{71}$ Instituições de direito processual civil, v. II, p. 397.

${ }^{72}$ Direito processual civil brasileiro, p. 80.

${ }^{73}$ Comentários ao Código de Processo Civil, p. 317.
} 
Trata-se, pois, de modalidade de intervenção de terceiro, na prática, voltada à solução da questão da ilegitimidade $a d$ causam $^{74}$, afastando as consequências da demanda em relação ao nomeante ${ }^{75}$.

É certo que JOSÉ DE ALBUQUERQUE ROCHA, em pioneira monografia sobre o instituto, critica essa noção prática e pondera que "se a nomeação à autoria fosse uma decorrência lógica da ilegitimidade ad causam do réu, como se afirma, na hipótese de sua não-concretização, a lei simplesmente determinaria a extinção do processo sem julgamento do mérito", mas não "a sua continuação". Afirma que o instituto "tem um caráter eminentemente dispositivo", que não se amolda à "natureza de ordem pública da ilegitimidade ad causam" e completa que, se prevalecesse o entendimento da correção da legitimidade, o Código de Processo Civil teria "duas soluções antagônicas para o mesmo problema. Uma, que impõe ao juiz resolvê-lo de ofício, ou seja, independentemente da vontade das partes, em qualquer tempo e grau de jurisdição, extinguindo sempre o processo sem julgamento de mérito (CPC, art. 267, VI). Outra, em sentido oposto, que confia a sua resolução à vontade das partes sempre com a continuação do processo (CPC, arts. 65 a 67$)^{, 76}$.

Parece responder à crítica de OVÍDIO ARAÚJO BATISTA DA SILVA, dizendo admitir a correção e, portanto, o tratamento diferente para este caso de ilegitimidade - em vista da dificuldade fática que permeia a descoberta do réu legítimo nas demandas em que se faz possível a nomeação.

Isso posto, a nomeação à autoria, diante de sua finalidade, é admissível, dentro do prazo da contestação, que ficará suspenso, em qualquer rito processual, exceto no procedimento sumário (art. 280 do CPC) e nos feitos dos Juizados Especiais (art. 10 da Lei 9.099/95), sendo cabível, segundo JOSÉ MANOEL DE ARRUDA ALVIM NETTO, até mesmo nos procedimentos especiais e no processo cautelar ${ }^{77}$. De qualquer maneira, impõese respeitar a natureza da ação promovida, de vez que a aplicação do instituto restringe-se

\footnotetext{
${ }^{74}$ Nesse sentido, José Manoel de Arruda Alvim afirma que o instituto "objetiva à correção da legitimatio ad causam, pois, no fundo a demanda é dirigida contra aquele que não é parte legítima" (Código de processo civil comentado, p. 191); e Cássio Scarpinella Bueno, Partes e terceiros no processo civil brasileiro, p. 189.

${ }^{75}$ Cf. Moacyr Amaral Santos, Primeiras linhas de direito processual civil, p. 19.

${ }^{76}$ Nomeação à autoria, p. 11-13.

${ }^{77}$ Manual de direito processual civil, p. 97.
} 
às ações reais (art. 62 do $\mathrm{CPC}$ ) e às pessoais que versem sobre indenizações em razão de danos à coisa (art. 63 do CPC).

Embora se trate de modalidade de intervenção de terceiros menos utilizada na prática do que as outras figuras, não há como desprezar, na praxe forense, sua utilidade e importância ${ }^{78}$, visando contornar e conferir meio de o autor, diante do pedido feito pelo réu antes da contestação, dirigir a ação em face daquele que efetivamente tem legitimidade passiva.

Assim, o processo, por força da nomeação realizada pelo réu e da concordância do autor e do nomeado, prosseguirá regularmente, evitando-se a desnecessária multiplicação de feitos, a sobrecarga do aparelho judiciário e a perda de tempo.

Em síntese, podem ser subscritas as apropriadas considerações de JOSÉ DE ALBUQUERQUE ROCHA, que destacou a importância da nomeação sob diferentes aspectos: sistemático, por estar "colocada no centro de um dos capítulos mais densos da Teoria Geral do Processo, que é o de sua dimensão subjetiva, ao qual estão ligados temas como o da natureza da ação, da legitimação, do mérito, dos limites subjetivos da coisa julgada"; funcional, pois "os poderes e deveres jurídicos que cria para as partes e para o terceiro existem em função da relação jurídica substancial que lhe está subjacente"; prático, por se afigurar de bastante aplicação; teleológico, em vista de o bem litigioso ser indiferente ao réu originário, de resguardar o direito do autor em protegê-lo "contra possíveis fraudes entre o nomeante e o nomeado", de salvaguardar o interesse do terceiro que tem "a possibilidade de defender seu suposto direito" e de o interesse da justiça resultar satisfeito ${ }^{79}$.

\subsection{Do chamamento ao processo}

3.5.1. Da origem do instituto. O chamamento ao processo é instituto que só foi introduzido no ordenamento brasileiro pelo Código de Processo Civil de 1973, buscado e

\footnotetext{
${ }^{78}$ José de Albuquerque Rocha destaca que, principalmente nas comarcas do interior, "é muito grande o número de ações, sobretudo possessórias, em que se torna necessário recorrer à aplicação das regras sobre a nomeação" (Nomeação à autoria, p. 10).

${ }^{79}$ Nomeação à autoria, p. 9-10.
} 
inspirado no direito português, que o denomina chamamento à demanda ${ }^{80}$. Possui, no entanto, semelhanças com o chamamento do terceiro por comunhão na causa, amplamente previsto pela lei italiana, e com o instituto alemão da Streitverkündung ${ }^{81}$.

3.5.2. Da noção e importância do instituto. O objetivo do instituto é permitir que o réu, no prazo para contestar ação voltada à cobrança de dívida (art. 78 do CPC), provoque a intervenção de terceiro que o autor, ao ajuizar a ação, poderia ter demandado diretamente como litisconsorte passivo daquele, mas não o fez. Permite com sua utilização que eventuais codevedores ou o devedor principal, não acionados originalmente pelo autor, sejam condenados juntamente com o chamante, que poderá, se pagar a dívida, cobrar do devedor principal ou dos demais co-obrigados a quota parte de cada um, no mesmo processo.

Para que se dê o chamamento, é necessário existir vínculo jurídico caracterizado como relação de direito material de dívida ou de responsabilidade, envolvendo autor, chamado e chamante.

Diante do chamamento ao processo realizado pelo réu, ao autor não assiste direito de discordar, devendo, se for realmente hipótese de cabimento do instituto, aguardar a citação do chamado, ainda que não pretenda litigar com ele. Haverá, então, a formação de litisconsórcio passivo facultativo simples ulterior ${ }^{82}$.

Inviável é o chamamento pelo autor, que, se quisesse demandar os outros obrigados, deveria, ao ajuizar a ação, ter incluído o chamado no polo passivo da lide; entretanto, não o tendo feito, não lhe assiste direito de valer-se do instituto, que é hipótese restrita de intervenção de terceiro de iniciativa da parte passiva. Além disso, é facultativo, pois o réu poderá, futuramente, em ação própria, exigir o reembolso dos co-obrigados. Outrossim, a sentença não é necessariamente idêntica para todos, razão pela qual o litisconsórcio é simples, além de ser ulterior, pois só será formado após o ajuizamento da ação.

\footnotetext{
${ }^{80}$ Está regulado no art. 329 do Código de Processo Civil de Portugal.

${ }^{81} \mathrm{Cf}$. Cândido Rangel Dinamarco, Intervenção de terceiros, p. 173-175.

${ }^{82}$ V. Daniel Ustárroz, A intervenção de terceiros no processo civil brasileiro, p. 131. 
O chamamento deve ser realizado, portanto, na fase de conhecimento, sendo cabível, inclusive, no processo monitório; não é admissível, contudo, no procedimento sumário (art. 280 do CPC) e nos Juizados Especiais (art. 10 da Lei 9.099/95). Também não é possível de se dar na fase de cumprimento de sentença ou mesmo nas execuções ${ }^{83}$, até porque a utilidade do instituto consiste na condenação do chamado, sendo necessária, portanto, uma sentença de mérito ${ }^{84}$, restringindo-se sua utilidade ao processo de conhecimento.

O art. 77 do Código de Processo Civil estabelece as três hipóteses de chamamento ao processo, facultando ao fiador - demandado isoladamente, por não haver benefício de ordem - chamar ao processo o devedor principal; ao fiador - demandado por dívida comum - chamar os demais fiadores; e ao devedor solidário - quando o credor lhe exigir total ou parcialmente a dívida comum - chamar os demais devedores solidários.

A última hipótese é a que possui maior importância, por ser, na prática, a mais aplicada. Nesse sentido, CÂNDIDO RANGEL DINAMARCO afirma que "o inc. III do art. 77 tem grande amplitude, ao admitir o chamamento ao processo 'de todos os devedores solidários, quando o credor exigir de um ou de alguns deles, total ou parcialmente, a dívida comum'. Aplica-se a todos os casos de solidariedade passiva em obrigação de dar dinheiro ou coisas determinadas pelo gênero e quantidade, exceto aos descritos nos incisos precedentes, que são regidos por estes (art. 77, inc. I-II)" ${ }^{\text {,85. }}$.

Se não se configurar a hipótese dessa modalidade de intervenção de terceiros, caberá ao juiz, como adverte ARRUDA ALVIM, indeferir o chamamento ao processo, “por causa do seu poder de velar pela rápida solução do litígio, impedindo atitudes meramente protelatórias das partes" ${ }^{~} 86$, nos termos do art. 125 , I, do texto processual.

\footnotetext{
${ }^{83}$ Antônio Cezar Peluso afirma não caber o chamamento sequer na execução de título extrajudicial, porque "não há sentença de conteúdo equivalente, pois, em caso de superveniência de embargos, os acolherá, ou não, sem oportunidade de julgar procedente ação que não existe e, aí, declarar as responsabilidades dos devedores" (Chamamento ao processo em execução, p. 188).

${ }^{84}$ V. Athos Gusmão Carneiro, Intervenção de terceiros, p. 181; Cândido Rangel Dinamarco, Instituições de direito processual civil, v. II, n. 609, p. 413; Celso Agrícola Barbi, Comentários ao Código de Processo Civil, p. 363-364; e José Manoel de Arruda Alvim Netto, Manual de direito processual civil, p. 333.

${ }^{85}$ Instituições direito processual civil, v. II, n. 610, p. 417.

${ }^{86}$ Código de processo civil comentado, p. 365.
} 
Caso a ação seja julgada procedente, haverá formação de título executivo judicial contra todos os litisconsortes passivos, contra apenas algum deles ou mesmo contra alguns. Além disso, aquele que pagar, exceto o devedor principal, subroga-se nos direitos do credor, podendo cobrar sua quota, por inteiro, do devedor principal, ou de um dos litisconsortes passivos, na proporção que lhes tocar (art. 80 do CPC).

Notavelmente, o instituto possui vantagens e é voltado a beneficiar o réu, na medida em que trará outros co-obrigados para o polo passivo, mas que poderá, ao final, também ser favorável ao próprio demandante ${ }^{87}$, que terá mais opções para exigir o cumprimento da obrigação.

Entre as vantagens do instituto, destaca-se que o chamado poderá, indiretamente, ajudar o chamante na defesa ${ }^{88}$. Acrescente-se, ainda, que se todos os réus forem condenados, o autor terá título executivo judicial contra todos - e não apenas contra o réu primitivo, como ocorreria se não se desse o chamamento - podendo executar qualquer um deles. Destaca-se, ademais, a possibilidade de o chamante pagar a totalidade do débito e de exercer o direito de regresso, tornando-se desnecessário promover nova ação posterior para os que seriam chamados.

Dessa forma, o chamamento ao processo é instituto que privilegia o princípio da economia processual, dado que será desnecessário ajuizar várias ações, em vista de os coobrigados estarem envolvidos num mesmo processo.

Quanto às desvantagens, por outro lado, o chamamento pode ser desinteressante ao autor, que perde sua autonomia para demandar somente em face daqueles que efetivamente lhe interessam, embora também tenha interesse de agir em relação a outros. Estrategicamente, pode lhe ser conveniente promover a demanda em face de um devedor, mas não em relação a outros, por razão de parentesco, amizade ou interesse negocial ${ }^{89}$.

\footnotetext{
${ }^{87}$ Em outro sentido, Celso Agrícola Barbi diz que "a finalidade do instituto é favorecer o devedor que está sendo acionado, porque amplia a demanda, para permitir a condenação também dos demais devedores, além de lhe fornecer, no mesmo processo, título executivo judicial para cobrar deles aquilo que pagar", enquanto que, "do ponto de vista do credor, o chamamento é desvantajoso" (Comentários ao Código de Processo Civil, p. 357-358).

${ }^{88}$ Daniel Ustárroz diz que o chamado poderá apresentar defesa de mérito e mesmo defesa indireta, exemplificando que poderá demonstrar a prescrição da dívida ou sua inexigibilidade ( $A$ intervenção de terceiros no processo civil brasileiro, p. 131).

${ }^{89}$ Cf. Celso Agrícola Barbi, Comentários ao Código de Processo Civil, p. 358.
} 
Além desses fatores desvantajosos, há situações em que o requerente sabe que o objeto da demanda pode ampliar-se, dependendo de qual dos co-obrigados é demandado, ou de ser a obrigação satisfeita de maneira mais rápida e fácil, de acordo com a solvibilidade dos codevedores.

Causará, de qualquer modo, um atraso na prestação jurisdicional, de vez que o deferimento do chamamento acarreta a suspensão do processo, enquanto se dá a citação do chamado (art. 79 do CPC) - o que pode ocorrer sucessivas vezes, dependendo do número de chamamentos - além de, no curso do processo, os prazos serem contados em dobro, se os réus estiverem representados por diferentes advogados (art. 191 do CPC). 


\section{DA DENUNCIAÇÃO DA LIDE}

\subsection{Da origem e evolução do instituto até o Código de Processo Civil de 1973.}

O instituto da denunciação da lide desenvolveu-se a partir do direito romano e do direito germânico primitivo, mas com características distintas.

No direito romano ${ }^{90}$, a denunciação da lide constituía instrumento por meio do qual se dava ao denunciado conhecimento da pendência do litígio e era obrigatória para, no caso de sucumbimento, este denunciado mover ação de regresso, o que só era exercido posteriormente e de forma autônoma. Preservava-se, pois, o direito de o denunciante ser ressarcido pelo alienante na hipótese de sucumbir, bastando promover, posteriormente, a ação de indenização, dado que a denunciação não importava na ação de regresso contra o denunciado.

Diante da denunciação, o comparecimento do denunciado ao processo não era obrigatório, mas ele poderia intervir, caso quisesse ${ }^{91}$. Se ele interviesse no feito, porém, seria apenas para auxiliar o denunciante e não poderia ser condenado a ressarci-lo do prejuízo sofrido no mesmo processo, mas apenas em outra demanda autônoma ${ }^{92}$. Esse sistema estava, pois, associado ao princípio da celeridade processual, em razão de a prestação da tutela jurisdicional dar-se, em tese, mais rapidamente, em vista de não se discutir a relação jurídica entre o denunciante e o denunciado; assim sendo, não havia

\footnotetext{
${ }^{90}$ Pondere-se que não se admitia a intervenção de terceiro em processo alheio, nos dois primeiros períodos do processo romano (período da legis actiones e período formulário). No terceiro período, denominado de cognitio extraordinem, o princípio da singularidade foi abrandado.

${ }^{91}$ Alfredo de Araújo Lopes da Costa diz que "a intervenção não era obrigatória. A notificação representava tão somente um pressuposto para o exercício, mais tarde, da acção que o evicto quisesse mover, para indemnizar se dos prejuizos que da evicção lhe houvessem resultado" (Da intervenção de terceiros no processo, p. 19).

92 José Alberto dos Reis explica que "a litis denunciativo exercia no direito romano a função de salvaguardar o direito de regresso, sem impor ao chamado ou denunciado a obrigação de se substituir ao denunciante. Mediante a denuntiatio litis, o ameaçado de evicção dava conhecimento àquele de quem recebera a coisa reclamada, de que fora demandado; o terceiro, informado assim da existência da demanda, podia intervir nela, se quisesse, tomando a posição de parte principal como réu ou de assistente a este; mas não era obrigado a intervir. Interviesse ou não, o demandado, desde que tinha denunciado a lide ao terceiro, alheador, ficava com direito a exigir deste, se decaísse na causa, a respectiva indemnização, que a princípio constitia no dobro do preço pago e mais tarde na reparação dos prejuízos" (Intervenção de terceiros, p. 61-62).
} 
ampliação objetiva do litígio, evitando-se tumulto processual. Resumia-se a denunciação à ciência do litígio.

A denunciação da lide, no direito germânico primitivo ${ }^{93}$, era distinta, embora também obrigatória, já que o denunciado substituía o denunciante no processo, assumindo a defesa deste ${ }^{94}$ e promovendo, desde logo, a ação de regresso ${ }^{95}$. Constituía, ao mesmo tempo, meio de defesa ${ }^{96}$ e de ataque, caracterizando-se como "uma verdadeira ação de garantia"97, condicionado o ressarcimento à sucumbência ${ }^{98}$.

$\mathrm{Na}$ reivindicação do direito germânico, além disso, existia acentuado caráter criminal, de modo que o comparecimento do denunciado se tornava obrigatório, em razão das implicações penais do instituto, a fim de afastar possível imposição de pena ${ }^{99}$. Em vista dessas particularidades, o cabimento da denunciação limitava-se somente ao réu, ao contrário do que se dava no direito romano, que o admitia tanto relativamente ao autor como ao réu.

Conferia-se, pois, preponderância ao princípio da economia processual, em razão de se resolver, definitiva e conjuntamente, a matéria do litígio primitivo e da lide secundária, por meio de uma única instrução processual e de uma única sentença. Além disso, evitava-se que o denunciante tivesse que buscar o ressarcimento em processo autônomo, afastando a possibilidade de haver sentenças contraditórias e impedindo a repetição do debate, em causas conexas, sobre questões já dirimidas.

\footnotetext{
${ }^{93}$ Ao contrário do que ocorria no direito romano, vigorava o princípio da universalidade no processo no direito germânico. Diante disso, a sentença não atingia somente as partes, mas produzia efeitos em relação a terceiros, razão pela qual ela era proferida perante todos em assembleia geral.

${ }^{94}$ Nesse sentido, José Alberto dos Reis enfatiza que "o traço característico da figura do chamamento à autoria no direito germânico primitivo era a obrigação de o garante se substuir no processo ao garantido e assumir a defesa deste". Acrescenta, ainda, que "o chamado, por virtude desta obrigação, tinha de intervir no processo, assumindo a posição de réu e libertando o demandado do ónus da defesa" (Intervenção de terceiros, p. 62).

${ }_{95}$ Ovídio Araújo Batista da Silva esclarece que o alienante assume "a defesa da coisa transmitida ao adquirente, que era excluído da causa, recebendo desde logo a indenização correspondente - praticamente a restituição do valor pago pelo adquirente - com o conseqüente desfazimento do negócio de alienação" (Comentários ao Código de Processo Civil, p. 327).

${ }^{96}$ Em razão dessa característica acentuada de auxílio na defesa, Milton Flaks associa "similitude entre a posição do denunciado, no direito tedesco, e a do assistente, no direito brasileiro, mesmo porque o art. 55 do CPC reproduz, com outras palavras, o $\$ 68$ da ZPO” (Denunciação da lide, p. 14-15).

${ }^{97}$ Cf. Sydney Sanches, Denunciação da lide no direito processual civil brasileiro, p. 05.

${ }^{98}$ Alfredo de Araújo Lopes da Costa explica que, diferentemente da característica romana, "num mesmo processo, perante o mesmo juiz, liquidavam-se as duas questões: a principal, de reivindicação, tendo o comprador como réo, e a regressiva, entre o comprador e o vendedor" (Da intervenção de terceiros no processo, p. 20).

${ }_{99}$ Cf. Antonio Carlos de Araújo Cintra, Do chamamento à autoria, p. 25-26.
} 
A denunciação possui, atualmente, em linhas gerais, dois objetivos, que foram buscados nos sistemas antes referidos. Os objetivos dessa intervenção de terceiro são, em primeiro lugar, de o terceiro auxiliar na defesa do denunciante; e, de outro lado, de indenizá-lo, na hipótese de o denunciante ser condenado. No sistema do direito romano, dominava o dever de indenização em relação ao de assistência, de forma que bastava uma simples comunicação da existência da lide, sem necessidade de promover-se simultaneamente a ação regressiva. Ao contrário, o dever de assistência era a função primordial do instituto no direito germânico antigo, devendo o denunciado defender a coisa objeto da demanda, pois já existia com a denunciação a ação de regresso.

Segundo AROLDO PLÍNIO GONÇALVES, que tratou com profundidade do instituto da denunciação da lide na sua tese de Livre Docência na Faculdade de Direito da Universidade Federal de Minas Gerais, o primitivo direito germânico influenciou o direito francês (exception de garantie), o direito italiano ${ }^{100}$ (chiamata in garanzia) e o brasileiro $^{101}$, sendo que o direito romano foi, de modo curioso, acolhido pela atual legislação alemã ${ }^{102}$.

A propósito, JOSÉ ALBERTO DOS REIS esclarece que as legislações de tipo germânico, "em vez de assimilarem o tipo germânico primitivo, assimilaram o tipo romano da litis denunciativo. $\mathrm{O}$ fenômeno tem a sua explicação na autoridade e prestígio do direito romano; quando este direito se difundiu, os povos de raça germânica, em vez de se manterem fiéis à tradição jurídica que lhes era própria, adoptaram e fizeram seu o figurino romano". Explica que "inverteram-se, pois, as atitudes. Os países latinos aderiram ao conceito germânico, por influência do Código francês, onde o tipo germânico tinha penetrado através do direito lombardo; ao invés, os países germânicos, imbuídos de romanismo, deram acolhimento e guarida ao conceito romano" $" 103$.

\footnotetext{
${ }^{100}$ De acordo com o art. 108 do Código de Processo Civil da Itália: "se il garante comparisce e accetta di assumere la causa in luogo dal garantito, questi può chiedere, qualora le altre parti non si oppongano, la propria estromissione. Questa è disposta dal giudice com ordinanza, ma la sentenza di merito pronunciata nel giudizio spiega i suoi effetti anche contro l'estromesso". Ao contrário do que se verifica no sistema brasileiro, importante destacar que a chiamata in garanzia zela apenas pelas garantias próprias, mas não pelas impróprias; que o juiz não pode excluir de ofício o garantido; e que os efeitos da sentença atingem também a figura do denunciante, mesmo que ele seja excluído do litígio.

${ }^{101}$ Ressalva-se que, na estrutura do instituto no direito brasileiro, não se dá a exclusão do adquirente e a substituição pelo alienante, ao contrário do que se verifica no direito germânico primitivo.

${ }^{102}$ Da denunciação da lide, p. 130-131.

${ }^{103}$ Intervenção de terceiros, p. 62-63.
} 
No direito português, a denunciação da lide, com traços mais marcantes do direito romano, foi regulada nas Ordenações Afonsinas, que a denominaram chamamento à autoria (Livro III, Títulos XL e XLI). Posteriormente, aquela legislação foi substituída pelas Ordenações Manoelinas (Livro III, Títulos XXX e XXXI), que conservaram as disposições sobre o instituto e acrescentaram seu caráter obrigatório. Nas Ordenações Filipinas, repetiu-se o que constava anteriormente (Livro III, Títulos XLIV e XLV), passando o chamamento à autoria a ser um ônus para o réu, não sendo possível a propositura da ação de regresso antecipada e eventualmente ${ }^{104}$. No Código de Processo Civil português de 1876, ampliou-se a aplicação do instituto, funcionando em todos os casos de evicção e "também em todos aqueles em que exista o direito de regresso para indemnização" 105 .

No Código de Processo Civil português de 1961, o instituto era denominado de chamamento à autoria e estava regulado nos arts. 325 a 329. Com a reforma de 1995, manteve-se sua denominação e os dispositivos que dele tratam passaram a ser os arts. 330 a 333. O atual art. 333 afasta o chamamento ao processo nos moldes disciplinados no direito brasileiro atual, ao dispor que "o réu que tenha acção de regresso contra terceiro para ser indemnizado do prejuízo que lhe cause a perda da demanda pode chamá-lo a intervir como auxiliar da defesa sempre que o terceiro careça de legitimidade para intervir como parte principal”.

O modelo português vigente segue, parcialmente, o sistema germânico primitivo, cabendo somente ao réu chamar o terceiro, que é citado para auxiliar na defesa daquele. É necessário, porém, se o denunciante perder a causa, o ajuizamento de outra ação autônoma para ser ressarcido ${ }^{106}$. Não há obrigatoriedade deste procedimento, constitui uma mera

\footnotetext{
${ }^{104}$ Cf. Aroldo Plínio Gonçalves, Da denunciação da lide p. 82-102; e Alfredo de Araújo Lopes da Costa, ao dizer que "as Ordenações não se referem á juncção das duas causas e sempre, ao contrario, pressupõem a condenação do réu da acção principal e uma posterior acção de regresso (II, 44, 2: 'ficando-lhe resguardado o seu direito'; III, 45, 3: 'e, sendo vencido no juízo principal e da appellação, a qual será obrigado a seguir até o fim'; III, 44, 3: 'ficando-lhe, porém, ao réo resguardado o seu direito')" (Da intervenção de terceiros no processo, p. 26).

${ }^{105}$ Cf. José Alberto dos Reis, Intervenção de terceiros, p. 71.

${ }^{106}$ Abílio Neto anota que o chamamento à autoria "tem por finalidade tão somente a de dispensar o titular do direito de regresso de demonstrar, uma acção futura contra o chamado, ter usado de todos os meios para evitar a condenação na aç̧ão que anteriormente lhe foi promovida". Acrescenta que "o uso desse incidente não dispensa o titular do direito de regresso de, noutra acção, demandar o chamado para obter a condenação deste no pagamento que o requerente do incidente foi obrigado a fazer ao autor da acção precedente".
} 
faculdade, bastando ao réu, se não pleitear o chamamento, demonstrar, na ação a ser promovida, que se empenhou para não ser condenado. A segunda parte do art. 330 do Código de Processo Civil português estabelece, ainda, que "a intervenção do chamado circunscreve-se à discussão das questões que tenham repercussão na acção de regresso invocada como fundamento do chamamento", de modo a haver conexão entre elas, a fim de justificar que o chamado seja responsabilizado pelo dano resultante da sucumbência do réu. Acrescente-se, ainda, que, embora o réu tenha que mover nova ação em face do terceiro, os efeitos da sentença proferida atingem esse terceiro, produzindo coisa julgada "relativamente às questões de que dependa o direito de regresso do autor ao chamamento" (art. 332, n. 2).

Essas sucintas referências à evolução do instituto da denunciação da lide, no direito alienígena, sem a preocupação de exaurir, por completo, seus elementos históricos, permitem delinear sua estrutura e suas particularidades. A partir disso, facilita-se a definição dos seus contornos no direito brasileiro.

No Brasil, o instituto foi previsto no Regulamento $737^{107}$ sob a denominação de chamamento à autoria, conservando as características romanas das Ordenações do direito lusitano $^{108}$. Inovou-se, ao estabelecer-se no art. 115 que, se o denunciado vier a juízo, com ele prosseguirá a causa, não sendo possível ao autor escolher litigar com o réu principal ou com o denunciado ${ }^{109}$.

Essa estrutura do instituto foi mantida, de um modo geral, nos Códigos estaduais, em vista de eles terem, via de regra, reproduzido o Regulamento $737^{110}$. AROLDO PLÍNIO GONÇALVES afirma que os Códigos estaduais consagram o instituto com os

Destaca não só que existe mera vantagem processual ao réu, mas também que não será reconhecido o seu direito de regresso ou a condenação do terceiro na ação em que ocorre o chamamento" (Código de Processo Civil anotado, nota 9.I ao art. 330, p. 392).

107 Art. 95: "Aquele que demandar ou contra quem se demandar acerca de coisa ou direito real, poderá chamar à autoria a pessoa de quem houve a coisa ou o direito real, a fim de resguardar-se dos riscos da evicção".

108 Bem como as características do atual direito alemão, no qual o terceiro é simplesmente notificado da pendência da lide para intervir.

${ }^{109}$ Sobre a necessidade de modificação subjetiva da relação processual, v. Antonio Carlos de Araújo Cintra, Do chamamento à autoria, p. 25-26; Cândido Rangel Dinamarco, Intervenção de terceiros, p. 150; e Sydney Sanches, Denunciação da lide no direito processual civil brasileiro, p. 07.

${ }^{110}$ V. José Manoel de Arruda Alvim, Código de processo civil comentado, p. 264-265; Egas Dirceu Moniz de Aragão, Sobre o chamamento à autoria, p. 25. 
mesmos traços do direito romano, exceção feita aos Códigos do Rio de Janeiro ${ }^{111}$ e do Ceará $^{112}$, que se afastaram dessa corrente e alinharam-se "ao padrão francês-italiano, vindo do antigo direito germânico, em que a ação de regresso propunha-se antecipadamente para ter decisão simultânea com a da ação 'principal', no que se tornaram precursores, no Brasil" $" 113$.

O instituto da denunciação da lide foi disciplinado no Código de Processo Civil de 1939, no capítulo da "Intervenção de terceiros" e, assim como o atual Código português, continuou a ser denominado de chamamento à autoria; a palavra "autoria", no entanto, foi usada com sentido de garantia, ou seja, obrigação de o antecessor prestar garantia ao sucessor. A denunciação da lide, que pode ser requerida pelo autor e pelo réu (art. 95), estava, então, regulada em limites bem restritos e estreitamente ligada à evicção ${ }^{114}$, como de resto sempre ocorreu na legislação pretérita ${ }^{115}$, consistindo condição necessária ao exercício da ação regressiva.

Assim, o instituto foi introduzido, na ordem jurídica brasileira, com a atual roupagem e com esta denominação de denunciação da lide, pelo Código de Processo Civil de $1973^{116}$. Substituiu o antigo chamamento à autoria, ao se aproximar em parte do direito germânico primitivo, dando relevância ao dever de assistência processual - colaborando,

111 O art. 1.200 do Código de Processo do Rio de Janeiro estabeleceu que: "Se o juiz condenar o réu a restituir a coisa demandada, na mesma sentença decidirá, quanto aos chamados à autoria, sobre as obrigações resultantes da evicção".

${ }^{112} \mathrm{O}$ art. 158 Código de Processo do Ceará previa que: "Se o juiz julgar procedente a ação, ordenando a restituição da coisa demanda, na mesma sentença, condenará os chamados à autoria a cumprir as obrigações resultantes da evicção. Parágrafo único: A sentença será, porém, nessa parte, executada em autos separados, a requerimento daquele em cujo favor essas obrigações se devam cumprir".

${ }^{113}$ Ressalva, ainda, que os Códigos da Bahia, de Pernambuco, de São Paulo e de Minas Gerais dispuseram sobre a denunciação da lide "como notificação do litígio a terceiro que, se quisesse, poderia intervir" ( $D a$ denunciação da lide, p. 110).

${ }^{114}$ Essas características são claras, a partir da redação do texto legal. No art. 95, caput, do CPC de 1939, estabeleceu-se que: "Aquele que demandar ou contra quem se demandar acerca de coisa ou direito real, poderá chamar à autoria a pessoa de quem houve a coisa ou o direito real, a fim de resguardar-se dos riscos da evicção". No art. 101, dispunha-se: “A evicção pedir-se-á em ação direta".

115 Paulo Palmeira critica essa limitação do instituto que se mantém estritamente vinculado à evicção, ao comparar com as leis processuais de outros países que "dão uma mais ampla finalidade ao chamamento à autoria, permitindo o seu uso não só no caso nítido de evicção, como ainda em outros casos em que o litisdenunciante possa exigir do terceiro a indenização dos prejuizos causados pela perda da demanda" ( $D a$ intervenção de terceiros nos principais sistemas legislativos: da oposição, p. 98).

${ }^{116}$ Moacyr Amaral Santos diz que houve um alargamento do conceito do instituto e critica a mudança da denominação, que teria ocorrido "sem qualquer justificativa plausível" (Primeiras linhas de direito processual civil, p. 25-26). No mesmo sentido, Ovídio Araújo Batista da Silva pondera que, "embora o Código lhe denomine denunciação da lide, na verdade a estrutura do instituto correspondente a um autêntico chamamento à autoria, posto que (...) o ato através do qual a parte faz a comunicação ao alienante da existência do litígio já contém a proposição da demanda indenizatória" (Comentários ao Código de Processo Civil, p. 327). 
pois, na defesa do denunciante - e, ao mesmo tempo, importando na propositura de ação de regresso $^{117}$, por meio da qual poderá formar título para ensejar o ressarcimento de suas perdas.

$\mathrm{Na}$ realidade, o instituto foi modernizado, ao fundir os modelos tradicionais e criar uma figura nova de intervenção de terceiro, acarretando, invariavelmente, retardo na prestação da tutela jurisdicional com ampliação subjetiva e objetiva. Há compensação, por essa demora, entretanto, ao se resolverem duas demandas num único processo, sem contradição, nem necessidade de repetições. Confere-se, portanto, maior relevância ao princípio da economia processual, que irá também refletir na efetividade, do que ao da celeridade. Buscou-se e se conseguiu uma medida de equilíbrio para o sistema entre a rápida solução do litígio e o interesse público de economizar atividade jurisdicional e evitar decisões conflitantes.

Ao contrário do que o nome faz supor, a denunciação, no direito brasileiro, não é uma simples denúncia da lide ao terceiro, como acontecia no Código de Processo Civil de 1939, mas uma ação de regresso. O denunciado, além de contribuir para a defesa do denunciante, o que o faz também no seu interesse, é réu na ação regressiva, razão pela qual deve empenhar-se ainda mais para evitar o risco do sucumbimento, pois a ação de regresso fica prejudicada se aquele vencer.

Essa particularidade de o denunciado auxiliar o denunciante e de a denunciação servir, desde logo, como ação de regresso constitui a grande afinidade do direito brasileiro vigente com o direito germânico primitivo. Importante destacar que existem, como se mostrará ao longo deste estudo, muitas características distintas do modelo germânico, como, por exemplo, a questão da falta de obrigatoriedade de denunciar; a não ocorrência da substituição processual do denunciante pelo denunciado; a definição sobre qual das partes pode denunciar a lide; e o não cabimento da denunciação em qualquer fase do processo. Dessa maneira, não é possível associar plenamente a denunciação da lide, tal como regulada no direito brasileiro vigente, ao modelo do direito germânico primitivo, mas é inegável que o instituto ostenta várias características suas.

${ }^{117}$ Pertinentes as observações de Milton Flaks, ao afirmar que o legislador "adotou uma fórmula sui generis, mesclando o sistema romano de denunciação da lide (litis denuntiatio) com o sistema germânico de chamamento em garantia (advocatio ad warrantum)" (Denunciação da lide, p. 04). 
É inegável que, ao longo do tempo, o instituto se tenha aperfeiçoado e modernizado, alcançando uma identidade própria e constituindo um sistema híbrido, com características vinculadas tanto ao direito romano, como ao direito germânico primitivo. De qualquer maneira, prevalecem, atualmente, traços do direito romano, especialmente na prática, pois é dada particular atenção à indenização ${ }^{118}$ em detrimento da colaboração na defesa do denunciante.

Inúmeras situações conferem preponderância à finalidade da indenização, havendo um viés voltado a permitir que a denunciação da lide facilite que o adversário do denunciante seja ressarcido. Exemplificativamente, faremos referência a diversas características que serão depois aprofundadas neste estudo. Com essa perspectiva indenizatória, o art. 73 do Código de Processo Civil admite a denunciação sucessiva, a fim de, principalmente, ampliar a garantia; e o art. 456 do Código Civil possibilita que a denunciação seja feita ao alienante imediato ou a qualquer dos anteriores, para assegurar que o adquirente não seja prejudicado e seja efetivamente indenizado por algum dos alienantes da cadeia dominial, restando, em segundo plano, a colaboração do denunciado na defesa. Acrescente-se, ainda, que se intensifica a adesão à corrente que admite a condenação direta do denunciado, apesar da falta de previsão expressa nesse sentido e de a denunciação da lide ser propriamente uma ação de regresso. Admite-se, outrossim, o ajuizamento de ação pela vítima do dano diretamente em face do segurador, deixando de lado o segurado causador do dano e ignorando que este último poderia ser demandado e, na condição processual de réu, poderia denunciar a lide ao segurador.

De outro lado, há uma tendência forte de restringir-se a denunciação da lide em hipóteses que privilegiem a defesa do denunciante. Nessa linha, destaca-se a resistência de introduzir-se fato novo, parecendo que só interessa mesmo o aspecto indenizatório e não a defesa do denunciante pelo denunciado. Nega-se, com frequência, por exemplo, a possibilidade de denunciação pelo Estado ao agente público causador do dano nas

\footnotetext{
${ }^{118}$ Valorizando o aspecto de ressarcimento, Athos Gusmão Carneiro reconhece que "o instituto soma ambos os propósitos", porém considera que prepondera o de inspiração do direito romano, ao concluir que "é de convir que o objetivo principal é o de ressarcimento" ( $O$ novo código civil e as alterações do instituto da denunciação da lide, de 'lege ferenda'”, p. 09). No mesmo sentido, Aroldo Plínio Gonçalves, ao afirmar que "colocou-se o legislador brasileiro do Cód. De Proc. Civil de 1973 (seguindo o anteprojeto elaborado pelo ilustre Prof. Alfredo Buzaid), fazendo importante na denunciação da lide sua natureza indenitária, deixando a plano secundário o aspecto da obrigação ou do ônus da defesa em Juízo" (Da denunciação da lide, p. 170).
} 
hipóteses do $\S 6^{\circ}$, do art. 37, da Constituição Federal, por o fundamento das responsabilidades ser distinto.

Além disso, os incisos II e III, do art. 75, do Código de Processo Civil não incentivam, em certo sentido, o direito de defesa, em vista de estabelecerem que, na hipótese de a denunciação ser feita pelo réu, o denunciado pode manter-se inerte, simplesmente negar a qualidade que lhe é atribuída ou confessar os fatos alegados pelo autor. Não há, pois, qualquer dever de auxiliar a defesa do denunciante, apesar de o denunciado ser atingido, de qualquer maneira, pelos efeitos da sentença, podendo ser condenado a pagar indenização na lide secundária.

Consideramos que ambas as finalidades da denunciação coexistem, mas há uma tendência, no sistema pátrio vigente, de privilegiar-se o aspecto indenizatório.

Ressalva-se, no entanto, que existe divergência quanto a essa predominância, havendo entendimento de que o instituto não pode ser rotulado propriamente como vinculado ao direito romano ou ao direito germânico primitivo. A propósito, MILTON FLAKS afirma que o modelo brasileiro é "híbrido ou sui generis"119.

De maneira positiva, o Código de Processo Civil de 1973 libertou-se da limitação da denunciação fundada apenas na evicção, prevendo, além da denunciação ao proprietário ou possuidor indireto, a denunciação à conservação de qualquer direito de garantia, independente da sua natureza. Não se restringe mais às ações reais, possuindo grande incidência em relação às ações pessoais ${ }^{120}$.

\footnotetext{
${ }^{119}$ Diz, nesse sentido, que "não é romano, na sua pureza, pois consente que os eventuais prejuízos do denunciante, conforme o caso, sejam declarados, apurados e compostos no mesmo processo, dispensando uma subsequente demanda regressiva; nem germânico, na sua concepção tradicional, porque a denunciação da lide, propriamente dita, não importa na interseção de um litígio subsidiário entre o denunciante e o denunciado. Facultou, é certo, que a denúncia seja cumulada com uma ação in eventum, mas como demanda incidente e paralela: sua propositura fica ao inteiro critério do titular do direito de regresso e não precisa ser decidida, necessariamente, na mesma sentença que resolver o litígio original" (Denunciação da lide, p. 99100).

${ }^{120}$ José Ignácio Botelho de Mesquita considera que o Código de Processo Civil de 1973 deu tratamento inteiramente novo ao instituto, "não só em relação à fisionomia que tinha no direito brasileiro anterior, como também novo em face dos elementos que se podem colher no campo do direito comparado, já que não se filia rigidamente a qualquer modelo alienígena, embora não deixe de se recolher algumas partes desses mesmos modelos" (Da ação de evicção, p. 90).
} 
Em vista das características da denunciação da lide, em especial o disposto no inciso III, do art. 70, e no art. 76 do Código de Processo Civil de 1973, o país, como ressalta AROLDO PLÍNIO GONÇALVES, “coloca-se entre os que dispõem de legislação mais avançada acerca do tema" "121, já que o instituto, "embora guarde semelhança com outros do direito antigo ou moderno de muitos povos, tem peculiaridades que o afastam de todos, por outro lado, se atende ao princípio da economia processual, não deve ser interpretado de tal modo que venha a pôr em risco esse mesmo princípio, em detrimento da presteza da prestação jurisdicional"122.

4.2. Da noção e importância da denunciação da lide. A denunciação da lide é modalidade de intervenção de terceiro, por meio da qual, presentes os requisitos legais, terceiro é chamado a um processo pendente, por iniciativa de qualquer das partes, a fim de auxiliar o denunciante na defesa de seus interesses e de, no caso de este sucumbir, ver definida, no mesmo processo, sua eventual obrigação de indenizar o vencido.

Trata-se de uma intervenção forçada, que pode ser requerida pelo autor e pelo réu, tornando-se o terceiro parte na lide secundária, independentemente de sua própria vontade $^{123}$. Destaca-se que, em razão de a denunciação da lide ser uma ação, ela não pode ser instaurada de ofício pelo juiz, pois fica sujeita aos princípios da iniciativa e da disponibilidade, de modo a depender da atuação da parte interessada, devendo conter “pedido certo e determinado", nos termos do art. 286 do Código de Processo Civil ${ }^{124}$.

Faculta-se, portanto, ao denunciante, no mesmo processo, promover ação regressiva contra terceiro, denunciado. A denunciação pressupõe que o denunciante tenha contra o denunciado uma pretensão própria, que somente terá sentido, todavia, na hipótese de o denunciante sucumbir na ação principal ${ }^{125}$. É uma demanda eventual, mas que, mesmo

\footnotetext{
${ }^{121}$ Afirma que o sistema brasileiro "superou, com larga vantagem, a todas as suas fontes, atingindo um ponto ideal a que a elas ainda foi dado chegar. Por um lado, os Códigos francês e italiano não contêm disposição igual à do item III do art. 70, cabendo à Jurisprudência criar a figura da 'garantia imprópria' para suprir-lhes a deficiência e, por outro, o Código português, de 1961, e mesmo o alemão, não conhece um artigo como o 76 do CPC brasileiro em vigor, permitindo a simultaneidade das decisões" (Da denunciação da lide, p. 323).

${ }^{122}$ Cf. Sydney Sanches, Denunciação da lide, p. 59.

${ }^{123}$ Antonio Carlos de Araújo Cintra classifica, corretamente, a vontade do denunciado como "inoperante" (Do chamamento à autoria, p. 104).

${ }^{124}$ Cf. Sydney Sanches, Denunciação da lide no direito processual civil brasileiro, p. 32.

${ }^{125}$ Piero Calamandrei sustenta que, sendo dupla a obrigação de garantia, pois é composta de duas obrigações simples - prestação de um serviço e prestação de uma indenização pecuniária - dupla também deverá ser a
} 
se considerada prejudicada, impõe, desde logo, ônus aos contendores. Ocorrerá, portanto, ampliação subjetiva e objetiva da demanda.

Dessa maneira, haverá, em um só processo, duas ações e duas relações jurídicas processuais, mas uma só instrução e uma só sentença que resolverá a ação principal e a denunciação da lide. Além de os fatos poderem ser melhor esclarecidos, evitam-se decisões contraditórias que poderiam ocorrer se tudo não fosse resolvido conjuntamente e atende-se ao interesse público ${ }^{126}$.

Destaca-se, ademais, existir caráter de prejudicialidade do resultado da ação principal sobre a denunciação da lide. A segunda ação é eventual e só terá significado prático se houver julgamento desfavorável ao denunciante da primeira ação, já que não há que se cogitar de responsabilizar o denunciado, se o resultado da ação principal for favorável àquele denunciante.

Além disso, a denunciação, sem margem de erro, é a modalidade de intervenção de terceiro mais usada na Justiça, sendo vantajosa, na prática, pois o denunciante, se for condenado na ação principal, poderá obter, via denunciação, título executivo a seu favor face àquele em relação a quem afirma ter direito de regresso ${ }^{127}$. Propicia, ademais, o julgamento de duas causas em um só processo e em uma única sentença, que enseja harmonia de julgados, evitando que o denunciado se exponha, posteriormente, em outro processo autônomo, no qual o juiz pela primeira vez tomará conhecimento dos fatos e poderá, obviamente, interpretá-los diferentemente.

A finalidade desse instituto é a economia processual e a jurisprudência tem admitido-o, de maneira sistemática, se for respeitada a celeridade e não houver relação

natureza da ação de garantia, desdobrada em uma ação de defesa do comprador, ameaçado de evicção pela demanda do terceiro, e em uma ação regressiva, que visa, não a primeira obrigação, mas a subsidiária obrigação pecuniária, e é proposta condicionalmente in eventum, subordinada a condição futura de perder o garantido a ação que chama di moléstia" (La chiamata in garanzia, p. 12).

${ }^{126}$ Compartilhamos do entendimento de Antonio Carlos de Araújo Cintra, ao concluir que o instituto "tem o objetivo precípuo de atender o interesse público de evitar a possibilidade de decisões contraditórias em questões de fato e de direito idênticas, que poderiam ocorrer se a ação de turbação entre o terceiro e o garantido contra os riscos da evicção não tivesse esse elo com a chamada ação direta de evicção" (Do chamamento à autoria, p. 100-101).

${ }^{127}$ Vicente Greco Filho diz que "a finalidade precípua da denunciação é a de se liquidar na mesma sentença o direito que, por acaso, tenha o denunciante contra o denunciado, de modo que tal sentença possa valer como título executivo em favor do denunciante contra o denunciado. Tudo isso na hipótese de o denunciante perder a demanda, porque, se vencê-la, nada há a liquidar" (Direito processual civil brasileiro, p. 138). 
jurídica marcada por fatos novos. Desse modo, sua incidência tem sido temperada nas hipóteses em que empecer o encerramento do litígio, a uniformidade da instrução e a tramitação processual, tornando indefinida, incerta ou distante do tempo a solução da ação principal. Acrescente-se que se reserva, sempre e em qualquer caso, a viabilidade da propositura de futuras ações regressivas autônomas.

Suas vantagens são as de vincular o terceiro ao que ficar decidido na causa entre o denunciante e seu adversário e buscar que o denunciado seja condenado, se for o caso, a ressarcir eventual perda que o denunciante possa sofrer, se este sair vencido na ação principal.

Diante do objeto do presente estudo, relevante destacar que o chamamento ao processo e a denunciação da lide possuem semelhanças, porém são institutos distintos, com características próprias. Em razão disso, verifica-se confusão quanto à aplicação deles, pois um é corriqueiramente utilizado no lugar do outro ${ }^{128}$.

Tecnicamente, as diferenças são relevantes. Na denunciação da lide, não existe vínculo jurídico entre o denunciado e a parte adversa do denunciante, ao contrário do que ocorre no chamamento ao processo ${ }^{129}$. Diante da existência de vínculo jurídico, é possível ao autor mover a ação não só em face do réu, mas também daquele que, se não for colocado no polo passivo, poderá ser chamado pelo requerido. Já na denunciação, o denunciado, exceto na hipótese de seguro de responsabilidade civil, por ser taxativamente prevista, em razão de ser considerada estipulação em favor de terceiro (art. 787 do CC), não pode ser demandado pelo adversário daquele com quem mantém vínculo jurídico no plano material.

\footnotetext{
${ }^{128}$ Apesar da distinção tipificada entre os dois institutos, Cândido Rangel Dinamarco considera que "é delicado e em alguns pontos muito transparente o véu que delimita as áreas de incidência do chamamento do processo e da denunciação da lide. Há tanto tempo do início de vigência do Código de Processo Civil, ainda vacilam e confundem-se os operadores do processo no momento de definir qual dessas duas espécies de intervenção é adequada ao caso, manifestando-se grande propensão de alargar a área de admissibilidade da denunciação da lide mediante a inversão do espaço reservado pela lei ao chamamento ao processo". Conclui que "os dois institutos são tão semelhantes, que no direito italiano correspondem a um só", o intervento su istanza di parte (Instituições de direito processual civil, v. II, p. 419).

${ }^{129}$ Cf. José Roberto dos Santos Bedaque, ao afirmar, corretamente, que "a distinção entre chamamento e denunciação é feita à luz da relação material. Enquanto na primeira hipótese de intervenção os chamados passam a ocupar a posição de réus, visto que todos integram a mesma situação da vida e o pedido, embora formulado a um deles, diz respeito a todos, na denunciação existe vínculo apenas entre denunciante, que exerce o direito de regresso, e denunciado, obrigado pela garantia" (Direito e processo - influência do direito material sobre o processo, n. 26.2., p. 131).
} 
Além dessas peculiaridades entre os institutos, é certo que, quanto ao procedimento, a denunciação da lide pode ser pleiteada tanto pelo autor como pelo réu (arts. 71, 74 e 75 do CPC), ao passo que só cabe ao réu fazê-lo no chamamento (art. 78 do CPC). A partir da interpretação literal da lei, em tese, o denunciado não poderá ser condenado a pagar de modo direto ao adversário do denunciante, mas apenas para o denunciante (art. 76) ${ }^{130}$, enquanto que, no chamamento, a sentença poderá condenar o réu e o chamado solidariamente (art. 80 do CPC). A denunciação está associada ao direito de regresso, ao contrário do chamamento ao processo, fundado na solidariedade.

4.3. Da denominação. A denunciação da lide sofreu grande evolução ao longo dos tempos e, da mesma maneira que subsistem tanto suas características inspiradas no direito romano, igualmente se passa quanto a pontos do direito germânico primitivo, sua denominação também foi atingida.

O instituto da denunciação da lide, como está denominado no Código de Processo Civil de 1973, também é tratado e conhecido como chamamento à autoria e chamamento à garantia.

Em vista de sua característica no direito brasileiro ser não só a de dar ciência da lide ao terceiro, mas também a de ajuizar, desde logo, ação de regresso, a denominação "chamamento à autoria" ou "chamamento à garantia" - tal como a usada na Itália - revelase, tecnicamente, mais apropriada, dado que denunciação da lide dá a falsa aparência de que se está simplesmente comunicando a pendência da demanda, como ocorria no direito romano, sem se pedir nada em relação ao denunciado.

O legislador andou na contramão, todavia, dado que, no Código de Processo Civil de 1939, o instituto era denominado de "chamamento à autoria", embora com características do direito romano, em vista de, simplesmente, ser dado conhecimento ao denunciado da existência do litígio, razão pela qual preferível era denominá-lo de denunciação da lide. No Código de 1973, todavia, modernizou-se o instituto ao também

${ }^{130}$ Ressalvada posição em sentido contrário de corrente que abordaremos. 
adotar-se a inspiração do direito germânico primitivo, por cumular ainda a ação de regresso, mas, equivocadamente, alterou-se a denominação para denunciação da lide, que apenas se ajusta à ideia de cientificar terceiro da existência de processo ${ }^{131}$.

Nesse sentido, adverte CELSO AGRÍCOLA BARBI sobre a incoerência da denominação nos sistemas processuais de 1939 e 1973, dado que, naquele, o chamamento à autoria era simples denunciação da lide, enquanto que, no atualmente em vigor, a estrutura da denunciação da lide corresponde a um autêntico chamamento à autoria, de vez que o ato pelo qual se faz a comunicação ao denunciado da existência do litígio já contém a proposição da demanda indenizatória ${ }^{132}$.

AROLDO PLÍNIO GONÇALVES também critica as denominações, afirmando que "o Código de Processo Civil, de 1973, rompeu com uma longa tradição, paradoxalmente, fazendo desaparecer o chamamento à autoria, que nada mais era que uma denunciação da lide, e, colocando em seu lugar a denunciação da lide que - agora sim outra coisa não é senão autêntico chamamento à autoria (ou em garantia - própria e imprópria), envolvendo sempre a propositura antecipada de ação de regresso, com o eventual pronunciamento sobre as duas causas em uma única sentença” ${ }^{133}$.

Essa também é a consideração de OVÍDIO ARAÚJO BATISTA DA SILVA, que ao tratar da denominação do instituto e confrontar o instituto nos dois sistemas, reconhece que "ocorre uma curiosa inversão" e adverte, que "essa incorreção na denominação do instituto, embora não passe de simples imprecisão vocabular, pode provocar alguma

\footnotetext{
${ }^{131}$ Cf. Cândido Rangel Dinamarco, ao considerar que "justamente quando o instituto deixou de ser mera denúncia, passando a incluir a ação de regresso, tratou o legislador de dar-lhe uma denominação, que antes não tinha, indicativa de tratar-se de mera ... denúncia (denunciação da lide)". Explica, ainda, que, no chamamento à autoria, "a palavra autoria comparece como equivalente de garantia" (Intervenção de terceiros, n. 76, p. 154).

${ }^{132} \mathrm{O}$ autor diz que "o uso da expressão 'chamamento à autoria', no Código de 1939, era inadequado, porque ela significa chamar à responsabilidade pela garantia; como naquela lei o chamamento era apenas para que a sentença fizesse coisa julgada também em relação ao alienante, o que havia era simples denunciação da lide como constava do Código alemão. O legislador de 1973, ao incluir no processo também a demanda do denunciante contra o denunciado - art. 76 - passou a regular agora verdadeiro chamamento à autoria. No entanto, quando esse nome veio a ser o adequado, abandonou, para usar o de denunciação, que é simples comunicação da existência da lide" (Comentários ao Código de Processo Civil, n. 402, p. 335). V., ainda, Luiz Fux, Intervenção de terceiros: aspectos polêmicos, p. 31.

${ }^{133}$ Da denunciação da lide, p. 127.
} 
incompreensão ou talvez equívocos, especialmente quando se busque comparar a disciplina dada pelo Código com os institutos análogos de outros sistemas" ${ }^{\text {"134 }}$.

Essa imprecisão da denominação não tem, de qualquer modo, como interferir na denunciação em si. É certo que "não há de ser o nome que definirá o alcance do instituto" 135 , mas as características do perfil adotado, vinculadas à tradição romana ou germânica antiga. Assim, as diversas mudanças ocorridas ao longo da história revelam que a denominação, embora relevante, não terá influência suficiente para abalar o instituto, podendo, no máximo, dificultar sua compreensão e sua correta definição.

\subsection{Do processo de conhecimento como aquele em que tem lugar a}

denunciação. A denunciação da lide é instituto próprio de processo de conhecimento ${ }^{136}$, em vista de suas finalidades e de sua natureza jurídica. Move o denunciante uma ação contra o terceiro, mas, a depender do que ocorra na lide principal, sua ação até poderá ser desnecessária e ficar prejudicada.

Dessa forma, por tratar-se de uma ação, ainda que de caráter eventual, proposta em face do terceiro, cujos direitos e obrigações serão definidos na mesma sentença da ação principal, o instituto só é cabível em se cuidando de processo de conhecimento, voltado à definição do conflito de interesses, o que se dá por meio de uma sentença. $\mathrm{O}$ art. 74 prevê que, se a denunciação for realizada pelo autor, o denunciado poderá aditar a petição inicial. Da mesma maneira, o art. 75, ao tratar das várias posturas que o denunciado pode adotar, refere-se à contestação, à revelia, à confissão e à defesa até o final, atos estes pertinentes ao processo de conhecimento. Já o art. 76 dispõe sobre o julgamento da ação principal e da regressiva, na mesma sentença, e prevê, textualmente, que valerá como título executivo.

Ao contrário da maioria das figuras de intervenção de terceiros, a denunciação da lide é admissível inclusive no procedimento sumário, diante da ressalva do art. 280 do texto processual, por força da redação que lhe deu a Lei 10.444/02, porém restrita apenas

\footnotetext{
${ }^{134}$ Comentários ao Código de Processo Civil, p. 325-326.

${ }^{135}$ Cf. Sydney Sanches, Denunciação da lide no direito processual civil brasileiro, p. 42.

${ }^{136}$ Cf. Fredie Didier Júnior, Curso de Direito Processual Civil, p. 353.
} 
às hipóteses em que a ação esteja "fundada em contrato de seguro". Incabível, no entanto, em processos perante o Juizado Especial (art. 10 da Lei 9.099/95).

Inexiste compatibilidade do instituto com a execução de título extrajudicial ou com o cumprimento de sentença, em razão das características e dos procedimentos ligados a cada qual ${ }^{137}$. Acrescente-se, ainda, que, em vista de a denunciação da lide consistir ação de regresso, ela será julgada conjuntamente com a ação principal, na mesma sentença, o que é incompatível com a execução e o cumprimento de sentença, que visam à satisfação da obrigação retratada no título ${ }^{138}$, havendo sentença somente para declarar o encerramento da execução, sem nada decidir.

Ao referir-se ao cabimento do instituto, AROLDO PLÍNIO GONÇALVES sustenta que a denunciação da lide "é instituto típico do processo de conhecimento, e só dele, não sendo cabível, de modo algum, em razão exclusivamente de sua natureza jurídica, por absoluta incompatibilidade, no processo de execução, que visa a atuar praticamente a norma jurídica concreta através de atos materiais, nem no processo cautelar cuja finalidade é resguardar o resultado útil de outro processo"139.

CÂNDIDO RANGEL DINAMARCO, após destacar que o julgamento a que o denunciado se vinculará é exclusivo do processo ou da fase cognitiva, ressalta ser inconcebível admitir o instituto "na execução forçada, no cumprimento de sentença, no processo monitório e no cautelar, em que julgamento algum de meritis se pede nem se proferirá $^{\prime 140}$.

\footnotetext{
${ }^{137}$ Oportunas as considerações de Araken de Assis, ao "argumentar que, na execução fundada em título judicial, aquelas situações que ensejam a denunciação já se apresentaram no processo de conhecimento, ocorrendo preclusão se não foram aproveitadas; e, na execução de título extrajudicial, criado no alvitre da desnecessidade de cognição prévia, incidentalmente à demanda executória não se admite a denúncia" (Manual da execução, n. 521.2, p. 1253).

${ }_{138}$ Nesse sentido, Celso Agrícola Barbi afirma não haver, na execução, "lugar para a denunciação da lide. Esta pressupõe prazo de contestação, que não existe no processo de execução, onde a defesa é eventual e por embargos. Além disto, os embargos são uma ação incidente entre o executado embargante e o exequente, para discussão apenas das matérias da execução. Não comportam ingresso de uma ação indenizatória do embargante com um terceiro. A sentença que decide os embargos apenas deve admiti-los, ou rejeitá-los, não sendo lugar para decidir questões estranhas à execução" (Comentários ao Código de Processo Civil, n. 425, p. 352-353).

${ }^{139}$ Da denunciação da lide, p. 312-313.

${ }^{140}$ Intervenção de terceiros, n. 79, p. 156.
} 
É certo que a denunciação é incabível na ação monitória, de vez que o réu é citado para pagar ou entregar a coisa (art. 1.102b do CPC), mas é admissível nos embargos à monitória, em vista da sua natureza de ação ${ }^{141}$.

É plenamente possível, outrossim, o reconvindo, na oportunidade de responder a ação que é em face dele promovida pela via reconvencional (art. 316 do CPC), denunciar a lide para terceiro, a fim de receber o auxílio do denunciado e de ser ressarcido, na hipótese de sucumbir na via reconvencional ${ }^{142}$. Para tanto, basta que estejam atendidos os pressupostos legais do art. 70 do Código de Processo Civil e que estes digam respeito à demanda proposta por reconvenção.

As hipóteses de cabimento de denunciação da lide também não se amoldam à medida cautelar, o que elimina essa modalidade de intervenção de terceiros, porém não impede sua admissibilidade na futura ação de conhecimento, de modo que se coloca o futuro denunciado, que não participou da cautelar, em posição de desigualdade, até porque o desfecho da cautelar poderá ser decisivo para o processo principal. Em vista disso, justifica-se que essa intervenção também se dê eventualmente na medida cautelar, a fim de o terceiro ser chamado para, simplesmente, auxiliar a parte na defesa dos seus interesses, descartando qualquer pretensão de garantia ou de indenização. Corresponde, portanto, a uma denunciação da lide anômala, que, na verdade, melhor corresponde a uma assistência, embora não exista previsão legal de que ela possa ser provocada ${ }^{143}$. Assim, o terceiro, na medida cautelar, será assistido, mas não efetivamente denunciado.

Desse modo, admissível a denunciação da lide na medida cautelar, desde que ela seja realizada com a finalidade de assistência, permitindo que o denunciado participe dessa cautelar. Isso pode se dar, por exemplo, na cautelar de produção antecipada de provas, revelando-se plausível a participação do denunciado, a fim de ele assistir ao denunciante $^{144}$. Nossos Tribunais já reconheceram essa possibilidade, em medida cautelar

\footnotetext{
${ }^{141}$ José Rogério Cruz e Tucci afirma, ao tratar da legitimidade ad causam no contexto da ação monitória, que se o réu "oferecer embargos, assume a posição processual de autor, viabilizando-se a denunciação da lide quando for ele titular de eventual direito de regresso contra um terceiro" (Ação monitória, p. 73).

${ }_{142} \mathrm{Cf}$. Clito Fornaciari Júnior, Da reconvenção no direito processual civil brasileiro, p. 181

${ }^{143} \mathrm{O}$ terceiro assumirá a posição de verdadeiro assistente, porém de maneira desvirtuada, dado que não é assistência voluntária, mas provocada. A propósito, v. Cândido Rangel Dinamarco (Intervenção de terceiros, p. 189-191).

${ }^{144}$ Nesse mesmo sentido, é a posição de Sydney Sanches, ao afirmar "que, no processo das ações cautelares em geral, não apenas nos meros procedimentos, qualquer das partes convoque o terceiro, a quem a lide no 
de produção antecipada de prova, "a fim de garantir o pleno exercício do princípio do contraditório e assegurar a eficácia da prova produzida nestes autos perante terceiro" ${ }^{145}$.

Diante das particularidades do instituto, que visa compelir o denunciado a assistir o denunciante e ressarci-lo, no caso de eventual sucumbimento, a admissibilidade é restrita aos processos de conhecimento.

4.5. Da dita obrigatoriedade da denunciação. Além de declinar as hipóteses de seu cabimento, o art. 70 do Código de Processo Civil estabelece, em seu caput, que a denunciação da lide é obrigatória. Ao assim dispor, afastou-se da previsão do Código de 1939, segundo o qual a parte poderia chamar à autoria, mas não estava obrigada a fazê-lo, como fica claro a partir do emprego da expressão "poderá chamar"146.

Tratava-se, de maneira expressa, de faculdade conferida à parte e, portanto, de um ônus processual, mas não de obrigação como agora dita. No atual sistema, a obrigatoriedade da denunciação da lide já foi amplamente debatida pela doutrina, sendo alvo de muita polêmica e crítica, desde o advento do então novo Código de 1973.

Perquirindo-se sobre o sentido desta obrigatoriedade, é preciso, por primeiro, separar a questão da adequação terminológica que gravita em torno da noção de ônus e de obrigação. Além disso, deve-se, a partir do direito material, enfrentar o risco da perda do direito de garantia ou de regresso contra o terceiro - caso a parte não provoque a intervenção daquele - bem como examinar o problema, confrontando-o com as características do instituto influenciado pelo direito germânico primitivo.

processo principal (futuro ou já atual) pode ser denunciada, não para contra ele deduzir, desde logo, pretensão de garantia ou indenização, mas para eventualmente lhe prestar assistência. Aí se configuraria, porém, reconheça-se, uma assistência provocada, que o Código não chegou a prever expressamente (v. arts. 50 e ss.) (Denunciação da lide no direito processual civil brasileiro, p. 144-146). V., ainda, Cândido Rangel Dinamarco, que considera essa denunciação atípica, denominando essa modalidade de "assistência provocada" (Instituições de direito processual civil, v. II, n. 601, p. 400-401).

${ }^{145}$ Cf. STJ, REsp 213.556/RJ, $3^{\text {a }}$ Turma, Min. NANCY ANDRIGHI, J. 20/08/01, DJ. 17/09/01; TJSP, AP 992.09.068247-4, 27 Câmara de Direito Privado, Rel. BERENICE MARCONDES CESAR, J. 20/10/09.

${ }^{146}$ Art. 95 do CPC de 1939: "Aquele que demandar ou contra quem se demandar acerca de coisa ou direito real, poderá chamar à autoria a pessoa de quem houve a coisa ou o direito real, a fim de resguardar-se dos riscos da evicção". 
Torna-se importante estabelecer, neste passo, a distinção entre ônus e obrigação. O ônus está diretamente associado às faculdades conferidas às partes, no sentido de haver liberdade de conduta processual; nada lhes é obrigatório, por serem livres e saberem dimensionar seus próprios interesses. Se o litigante não atuar, suportará as consequências de sua omissão. A propósito, CARNELUTTI confere o exato sentido ao conceito de ônus: constitui o exercício de uma faculdade para se obter certa vantagem, cujo exercício é necessário para se alcançar determinado interesse ${ }^{147}$.

Em outro sentido, a obrigação caracteriza-se pelo dever de uma parte para com a outra. Em vista disso, o descumprimento da obrigação não repercute negativamente para a própria parte que deixou de realizá-lo, constituindo um comportamento ilícito e, deste modo, sancionado, por influir diretamente no interesse da outra parte.

A obrigação e o ônus possuem elemento formal comum, consistente no vínculo da vontade, mas a distinção entre eles decorre do elemento substancial, em vista de o vínculo ser imposto, na obrigação, para a tutela de um interesse alheio, enquanto, no ônus, para o resguardo de um interesse próprio.

Na prática, se não houver a denunciação da lide, o denunciante não terá o auxílio do denunciado na defesa de seus interesses, perderá a oportunidade de ser indenizado, no mesmo processo, em regresso - na hipótese de ser condenado - e não obterá sentença formalmente única. A situação, ao menos em sentido técnico, não se amolda propriamente à obrigação, dado que a denunciação é exercício do direito de ação e não existe dever de exercitar este direito. Constitui-se, na verdade, um ônus processual, de vez que, se não houver a intervenção de terceiro, esses benefícios não serão obtidos, arcando a parte, pois, com a consequência da desvantagem decorrente, que culmina com o risco de, além de não obter, desde logo, o título executivo, também não o conseguir pela via autônoma.

CÂNDIDO RANGEL DINAMARCO diz que se trata de uma "falsa obrigatoriedade", de vez que "a desvantagem que a parte suportará por não haver feito a litisdenunciação, podendo fazê-la, ordinariamente não irá além da privação das vantagens

${ }^{147}$ Sistema di diritto processuale civile, pág. 55. 
que se habilitaria a receber se a houvesse feito" ${ }^{\text {148 }}$, restritas ao quanto decorre da economia processual.

Também na linha de que se trata de um simples ônus processual, OVÍDIO ARAÚJO BATISTA DA SILVA afirma ser incorreta a referência à obrigatoriedade, apontando para "inúmeras hipóteses de sobrevivência de ações de regresso que devem ser exercidas em demanda independente" ${ }^{, 149}$.

A partir da distinção entre ônus e obrigação, não há dúvida de que a obrigatoriedade da denunciação da lide, por esse ângulo, não se revela correta, dado que a parte que deveria denunciar arcaria, caso não o fizesse, apenas com o ônus consequente. Apesar da correção dessa premissa, parece que o legislador, ao ditar a obrigatoriedade, não estava cogitando enfrentar a questão por esta ótica, estando mais intimamente associado a outros enfoques que passarão a ser tratados, notadamente a problemática da perda do direito material.

Assim, a questão há de ser examinada sob a perspectiva da consequência da falta da denunciação da lide, como fato que efetivamente acarreta a perda do direito de garantia ${ }^{150}$ ou de regresso.

Diante desse enfoque, a hipótese do inciso I, do art. 70, do Código de Processo Civil deve ser examinada separadamente, por força de o art. 456 do Código Civil estabelecer que, para poder exercitar o direito que da evicção lhe resulta, o adquirente notificará do litígio o alienante imediato ou qualquer dos anteriores ${ }^{151}$. Se não houver a denunciação da lide e o adquirente perder a coisa, o alienante não será responsável pela evicção e o adquirente terá perdido o direito pelo não cumprimento da regra do Código Civil.

\footnotetext{
${ }^{148}$ Intervenção de terceiros, v. II, n. 78, p. 155.

${ }^{149}$ Comentários ao Código de Processo Civil, p. 328-329.

150 Piero Calamandrei definiu garantia como "a defesa em juízo, dirigida a rechaçar uma demanda de um terceiro, ou a sustentar uma demanda contra um terceiro, e o ressarcimento do dano derivado da defesa não feita ou fracassada, que uma pessoa (chamada garante) é obrigada a prestar, por lei ou por convenção, a outra pessoa (chamada garantido)" (La chiamata in garanzía, p. 09).

${ }^{151}$ No mesmo sentido, era o art. 1.116 do Código Civil de 1916. O legislador do Código Civil de 2002 manteve, nesse passo, a redação, ao dispor que "o adquirente notificará do litígio o alienante", seguindo terminologia de então e não atentando, de maneira equivocada, para as alterações do instituto ocorridas com o Código de Processo Civil de 1973, que mesclou as características do direito romano e do direito germânico primitivo.
} 
A consequência da hipótese do inciso I, do art. 70, do texto processual é distinta da dos incisos II e III, dado que, naquela, a não denunciação acarreta consequência definitiva, perdendo o adquirente o direito de ser ressarcido pelo alienante, em vista da regra de direito material, não lhe socorrendo promover ação autônoma. Diante disso, revela-se correto, por essa ótica, o uso da terminologia obrigatória, porém apenas para essa específica hipótese, por força do efeito irreversível da não denunciação da lide, em vista de eventual demanda autônoma de indenização estar fadada ao insucesso, diferentemente do que se dá nas previsões dos incisos II e III.

Em vista de o direito material nada dispor quanto às hipóteses dos incisos II e III, tratando com esse rigor apenas da evicção, não há como cogitar que a não denunciação, naqueles casos, possa acarretar eventual perda do direito de regresso.

Em razão desse tratamento diferente, preferível seria o legislador processual não prever a obrigatoriedade, limitando-se a estabelecer as hipóteses de denunciação da lide, até porque a perda do direito de regresso não decorre da lei processual, mas do Código Civil. Se a parte não provocar a intervenção de terceiro, é óbvio que não obterá o direito de regresso naquela demanda, arcando com as implicações decorrentes, conforme o caso concreto, que terá que enfrentar em demanda autônoma. Na garantia decorrente da evicção, perderá o direito, por força da regra de direito material, enquanto que, nas garantias derivadas da transmissão de direito e da responsabilidade civil, poderá, por inexistir qualquer sanção na lei civil ou processual, exercer o direito de regresso, em processo autônomo $^{152}$, correndo os riscos que não sofreria caso se houvesse valido da intervenção de terceiro, evitando, inclusive, a possibilidade de decisões contraditórias.

Ao tratar da obrigatoriedade por este plano, ARRUDA ALVIM explica que "o significado da palavra obrigatória, utilizada no caput, do art. 70, varia" conforme as hipóteses dos incisos. Adverte que, na hipótese de evicção, a obrigatoriedade "será somente para resguardar-se o adquirente dos riscos da evicção (ou da responsabilidade por perdas e danos se a denunciação obrigatória estiver prevista em lei ou em contrato). Em não desejando o adquirente (autor ou réu), por motivos que não interessam, ou por haver

${ }^{152}$ Cf. Luiz Fux, Intervenção de terceiros: aspectos polêmicos, p. 35. 
convenção em contrário, excluindo integralmente a responsabilidade pela evicção, resguardar-se desses riscos, será, só o adquirente (autor ou réu), parte legítima”. O sentido de obrigatoriedade do inciso II "somente poderá ser entendido como constituindo-se obrigatória a citação, para fins de o litindenunciante haurir o benefício de, no mesmo processo - embora na sua ação de garantia, especificamente proposta, mercê da denunciação da lide - obter, desde logo, a sentença”. Já no caso do inciso III, também considera que "em não havendo denunciação da lide, não se poderá falar em perda do direito da ação regressiva (a não ser que estabelecido, assim, contratualmente ou por lei expressa a respeito)" ${ }^{\prime 153}$.

CLITO FORNACIARI JÚNIOR considera que, em virtude da obrigatoriedade da denunciação não estar associada às consequências de seu não cumprimento, a previsão torna-se "vazia de sentido diante do não sancionamento. Apenas com relação ao n. I do referido artigo, encontramos a disposição do art. 1.116 do Código Civil - fora, portanto, da norma processual - que leva a que a não denunciação da lide impossibilita o exercício dos direitos decorrentes da evicção". Nas hipóteses dos incisos II e III do art. 70, conclui ser facultativa a denunciação ${ }^{154}$.

CELSO AGRÍCOLA BARBI tinha posição rigorosa quanto às consequências da obrigatoriedade; reviu, porém, logo em seguida, sua posição e reconheceu "que a falta da denunciação de lide no caso do item I, do art. 70, acarreta a perda do direito à indenização pela evicção, com base no art. 1.116 do Código Civil. Mas a falta de denunciação da lide nos casos dos itens II e III daquele artigo não leva à perda do direito de indenização ou de regresso; apenas impede que esse direito seja exercido no processo onde deveria ter sido feita a denunciação, de modo que ele só poderá ser reclamado em processo posterior"155.

Acrescente-se, outrossim, o raciocínio de SYDNEY SANCHES, que concluiu que, "na hipótese do inciso I do art. 70 do CPC de 1973, o ônus de denunciar a lide acarreta à parte, que o desatende, a perda do direito material resultante da evicção, nos termos, ainda, do art. 1.116 do CC [de 1916]", enquanto que, "nas hipóteses dos incisos II e III, o descumprimento do ônus não implica na perda do direito à ação autônoma e menos

\footnotetext{
${ }^{153}$ Código de Processo Civil comentando, p. 247, 258 e 262.

${ }^{154}$ Referindo-se ao Código Civil anterior, mas que não foi, nessa parte, alterado no de 2002 (Reconhecimento jurídico do pedido, p. 39).

${ }^{155}$ Comentários ao Código de Processo Civil, n. 407, p. 341.
} 
ainda do direito material de indenização ou de regresso; a omissão apenas impede a formação, desde logo, nos mesmos autos, de título executivo contra o terceiro (art. 76) e sujeita o omisso aos riscos integrais de uma ação autônoma, em que amplamente se poderá discutir toda a matéria de fato ou de direito relacionada (inclusive) ao mérito, ventilada, ou não, bem ou mal explorada na ação originária"156.

ATHOS GUSMÃO CARNEIRO sustenta a tese por ele apresentada e que resultou aprovada por unanimidade, no Ciclo de Estudos de Processo Civil, realizado em Curitiba, em agosto de 1983, pela Ordem dos Advogados do Brasil e pela Associação dos Magistrados do Paraná, com a seguinte conclusão: “A não denunciação da lide somente acarreta a perda da pretensão regressiva nos casos de garantia formal, ou seja, de evicção e de transmissão de direitos" ${ }^{\prime 157}$.

Ao tratar da obrigatoriedade do instituto, VICENTE GRECO FILHO, por seu turno, afirma que "a falta de denunciação acarreta a perda do direito que da evicção resulta, nos termos do art. 70, I, do Código de Processo Civil e [do revogado] art. 1.116 do Código Civil”, mas não acarreta, nos casos dos incisos II e III, a perda do direito de regresso ou de indenização, sendo que a obrigatoriedade, nestas previsões, "limita-se ao interesse da parte obter, desde logo, o título executivo contra o responsável e ao de evitar o risco de, na ação posterior, perder o direito de regresso por motivo que poderia ter sido oposto ao autor primitivo" $" 158$.

Embora reconheça que a “'obrigatoriedade’ da denunciação da lide restringe-se à hipótese do inc. I do art. 70”, FREDIE DIDIER JÚNIOR sustenta, diante de o art. 456 do Código Civil ter mantido a redação do art. 1.116 do Código Civil de 1916, ser a disposição de direito material obsoleta e conclui que "essa desarmonia não pode ser interpretada como se ainda se pudesse falar em perda do direito de regresso, acaso não se promovesse a denunciação da lide, interpretação que ignora o aspecto histórico do problema e ainda

\footnotetext{
${ }^{156}$ Denunciação da lide, p. 50.

${ }^{157}$ Intervenção de terceiros, n. 43, p. 109.

${ }^{158}$ Direito processual civil brasileiro, p. 141-147.
} 
prestigia um possível enriquecimento ilícito do alienante a expensas do adquirente (em afronta às regras dos arts. 884-886 do CC/2002"159.

Essa obrigatoriedade, de qualquer modo, afronta a regra do art. 456 do Código Civil, que determina, ainda que de maneira imprecisa, que "o adquirente notificará do litígio o alienante", constituindo norma cogente, que não admite a referida interpretação.

Assim, não se pode conferir interpretação rígida ao sentido de obrigatoriedade e concluir que, à falta de denunciação, perde-se o direito de regresso e de indenização. Na verdade, a denunciação será obrigatória para não se perder o direito de regresso, na eviç̧ão, bem como para se obter, desde logo, título executivo judicial, nos termos do art. 76 do Código de Processo Civil. De qualquer forma, em não havendo a denunciação e saindo vencido aquele que a deveria ter feito, não haverá, exceto na hipótese da evicção ${ }^{160}$, qualquer perda de direito, a ser buscada em outro processo posteriormente ${ }^{161}$, porém a situação do denunciante poderá ser dificultada, de vez que o denunciado, por não intervir na lide, não deduzirá defesa, que lhe poderia beneficiar.

Há, no entanto, que se temperar ainda mais a perda do direito de regresso, no caso de evicção, dado que o evicto não pode ser prejudicado, no âmbito dos Juizados Especiais e no procedimento sumário, nos quais é incabível o instituto. Se é vedada a demanda regressiva, não pode o adquirente, por coerência, ser prejudicado pelo não exercício desse direito. De maneira tolerante, deve-se admitir, portanto, que seja promovida ação autônoma nesses casos, a fim de permitir que o adquirente busque seus direitos e não sofra as consequências da rigidez processual dos procedimentos.

\footnotetext{
${ }^{159}$ A denunciação da lide e o art. 456 do novo CC: a denunciação per saltum e a "obrigatoriedade”, p. 264. Cf., ainda, Flávio Luiz Yarshell, Evicção e denunciação da lide no novo Código Civil: contribuição ao direito bancário, p. 35.

${ }^{160}$ Cf. Daniel Ustárroz, ao afirmar que a denunciação só será 'obrigatória' "no caso do exercício do direito de evicção. Nos demais casos, o não-oferecimento da denunciação não tem o condão de extinguir a pretensão de regresso, que poderá ser deduzida em processo autônomo" (A intervenção de terceiros no processo civil brasileiro, p. 91).

${ }^{161}$ Essa é a posição predominante no Superior Tribunal de Justiça: “A denunciação da lide só é obrigatória em relação ao denunciante que, não denunciando, perderá o direito de regresso, mas não está obrigado o julgador a processá-la, se concluir que a tramitação de duas ações em uma só onerará em demasia uma das partes, ferindo os princípios da economia e da celeridade na prestação jurisdicional" (EREsp 313.886/RN, Rel. Min. ELIANA CALMON, $1^{a}$ Seção, J 26/02/2004, DJ 22/03/2004, p. 188).
} 
O significado da obrigatoriedade deve, ainda, ser enfrentado, de acordo com as características científicas do instituto no direito brasileiro, filiado e influenciado pelo direito germânico primitivo. A partir desse prisma, a denunciação da lide deveria efetivamente ser obrigatória, em vista de não constituir uma simples notificação do litígio, mas uma ação de regresso antecipada do denunciante em face do denunciado, condicionada ao sucumbimento da ação que lhe foi movida.

Ao abordar com profundidade o instituto, AROLDO PLÍNIO GONÇALVES destaca, após ressaltar a influência do direito germânico primitivo, seguido pelo sistema brasileiro, que o fundamento da obrigatoriedade da denunciação da lide "está na existência da relação de garantia. Se houver garantia própria (formal) - por transmissão de direitos a denunciação é obrigatória, sob pena de decair da pretensão de regresso". Conclui, ainda, que não há que se lamentar a redação do direito positivo, pois, na sua ótica, "a denunciação da lide é obrigatória e o denunciado-garante tem o direito de ser chamado à causa, ao passo que, correlativamente, o denunciante-garantido tem o dever de chamá-lo"162.

Abordando o instituto apenas no plano processual e considerando as características e influências do modelo seguido, não há razão para criticar o legislador brasileiro, que se manteve, quanto a esse aspecto, fiel às origens do sistema germânico antigo e não eliminou a palavra "obrigatória", que, de maneira precisa e uniforme, dá correto trato à denunciação.

Em vista do modelo adotado no direito brasileiro, fica claro que o sentido de obrigatoriedade está ligado à necessidade de a parte pleitear a intervenção de terceiro, a fim de obter, no mesmo processo, título executivo judicial, caso seja vencido no processo principal. Privilegiam-se a economia e a celeridade processuais, dado que haverá apenas uma sentença formal e uma única instrução processual, relativamente às duas relações jurídicas processuais existentes, e evitam-se decisões conflitantes, que é o objetivo dessa modalidade de intervenção. Se a parte não requerer a denunciação, a finalidade do instituto não será alcançada, razão pela qual a previsão de obrigatoriedade é coerente.

${ }^{162}$ Denunciação da lide, p. 188-192. 
Salienta-se, no entanto, a inexistência, nos sistemas influenciados pelo direito germânico primitivo, desse caráter de obrigatoriedade, que seria natural, caso fossem seguidas fielmente suas características.

No direito francês, não há esse sentido, apesar de constituir comunicação da existência do litígio e propositura de ação de regresso, que também pode ser ajuizada de forma autônoma.

O direito italiano afasta-se parcialmente da obrigatoriedade da chiamata in garanzia. Na realidade, o instituto possui características distintas das do direito brasileiro, que não se filia rigidamente ao modelo germânico antigo; segundo o art. 1.485 do Código Civil italiano, aquele que deveria ter denunciado a lide para terceiro perde o direito à garantia, se este provar que existiam razões suficientes para que a pretensão da demanda principal fosse rejeitada.

Destaca-se que a obrigatoriedade da denunciação também é traço característico do instituto no direito romano. Apesar disso, se o réu, no direito português, não fizer o chamamento à autoria, por meio do qual há simples notificação do litígio, terá que provar, ao promover ação voltada à indenização em face daquele que seria denunciado (chamado), que se esforçou para evitar a condenação, nos termos do art. 325 do Código de Processo Civil português. A noção de obrigatoriedade também é, portanto, nitidamente temperada e restrita $^{163}$.

Assim não é possível conferir uma resposta simplista e direta ao sentido da obrigatoriedade da intervenção de terceiros. É necessário, previamente, identificar qual é o prisma sob o qual a denunciação está sendo enfrentada, não havendo dúvida de que o legislador, ao tratar do art. 70 do nosso Código, regulou-o a partir da característica

\footnotetext{
163 José Inácio Botelho de Mesquita destacou não ser "uniforme em direito comparado, o tratamento dispensado à obrigatoriedade da denunciação da lide. É facultativa a denunciação da lide nos C.C. da França (art. 1.640), da Itália (art. 2.111), e no C.P.C. de Portugal (art. 325)", bem como "também no C.P.C. Alemão (§ 72), que não dispõe expressamente sobre a mencionada sanção, muito embora esta decorra das regras sobre a coisa julgada. É obrigatória a denunciação da lide nos C.C. da União Soviética (art. 250), da Espanha (art.1.482), do México (art. 2.124), do Peru (art. 1.375), do Chile (art. 1.843), do Uruguai (art. 1.705), e da Bolívia (art. 1.056), sempre sob pena de perder o adquirente o direito que da evicção lhe resulta" (Da evicção, p. 86-87). No entanto, não há como ignorar que cada um desses sistemas possui uma realidade própria e seguiu modelo distinto, não sendo possível, a partir dessa simples classificação, fazer qualquer consideração mais profunda, de vez que seria necessário realizar uma análise mais detida para servir de parâmetro quanto à adequação do sentido da obrigatoriedade.
} 
histórica do instituto, influenciado pelo direito germânico primitivo. Revelam-se corretas, outrossim, as considerações dos doutrinadores sobre o aspecto da noção de ônus e de obrigação, bem como sobre a perda da pretensão de regresso.

De qualquer maneira, não é possível confundir as perspectivas, em decorrência da expressão obrigatória. Caso essa modalidade de intervenção de terceiro não seja empregada, não há como excluir o direito de o denunciante promover ação regressiva, exceto na hipótese de evicção, em decorrência da previsão de direito material.

Diante da imprecisão que a palavra "obrigatória" acarreta, dependendo da perspectiva que a questão seja enfrentada, não haveria qualquer prejuízo em eliminá-la, de vez que acabaria com inútil debate em torno da noção de ônus e obrigação, até porque a ninguém é conferido o direito de alegar o desconhecimento da lei; sepultaria a discussão sobre a perda do direito de ser indenizado ou reembolsado, o que sucede somente na hipótese de evicção, por força da lei de direito material; e não se subtrairia a influência histórica e predominante do direito germânico primitivo.

Ao suprimir a polêmica quanto à obrigatoriedade, revela-se positivo o Projeto de Lei 6.960/02 $2^{164}$, relativamente à proposta de alteração do art. 456 do Código Civil, que passaria a ter a seguinte redação: "Art. 456: Para o direito que da evicção lhe resulta, independe o evicto da denunciação da lide ao alienante, podendo fazê-la, se lhe parecer conveniente, pelo princípio da economia e da rapidez processual". Se a proposta for acolhida, elimina-se a necessidade até mesmo de o evicto valer-se da ação regressiva, podendo, da mesma maneira que nas outras hipóteses do instituto, ajuizar posterior ação autônoma.

Assim, a exclusão da previsão processual de obrigatoriedade não causaria qualquer deficiência ao sistema e não retiraria o seu verdadeiro sentido. Isso porque, no direito brasileiro, não se polemiza, apesar das controvérsias destacadas, não só quanto à exceção do direito de promover ação de regresso autônomo apenas na hipótese de evicção - convivendo harmonicamente o direito material e o processual - mas também quanto à influência do sistema germânico primitivo ao instituto adotado.

\footnotetext{
${ }^{164}$ No mesmo sentido, Fredie Didie Júnior reputa benéfica a proposta (A denunciação da lide e o art. 456 do novo CC: a denunciação per saltum e a "obrigatoriedade", p. 264).
} 
4.6. Da posição processual do denunciado. A posição jurídica do denunciado é questão polêmica e controvertida, revelando-se fundamental abordá-la, até mesmo porque, a depender do que ela represente, o instituto repercutirá diferentemente em contornos relevantes do processo e quanto aos atos que poderão ser praticados pelas partes com validade e eficácia.

Não há dúvida de que o denunciado, uma vez citado, será sempre réu na ação de regresso, na qual o denunciante deduz pretensão de direito material em decorrência do vínculo jurídico existente, tornando-se, pois, sujeito de faculdades, ônus, poderes e deveres. Por ser parte, ele será diretamente atingido pelos efeitos da coisa julgada da lide secundária, pouco importando a postura que adote, apresentando defesa, sendo revel, dentre outros possibilidades.

A questão torna-se interessante, diante da dificuldade de se precisar e da grande divergência sobre a posição processual que o denunciado assume na ação principal. Há basicamente duas correntes, cada qual com seus argumentos: uma considerando que o denunciado será litisconsorte do denunciante e outra que o posiciona como assistente deste. De qualquer maneira, não significa que o denunciado seja litisconsorte ou assistente, mas apenas que recebe esse tratamento.

A literalidade do texto legal conduz, inegavelmente, a reconhecer que o denunciado assume a condição de litisconsorte do denunciante. O legislador previu que tanto o denunciado pelo autor (art. 74 do CPC), como o denunciado pelo réu (art. 75, I, do CPC), tornam-se litisconsortes do denunciante ${ }^{165}$. Para assumir essa posição, basta o denunciado, na denunciação feita pelo autor, comparecer ao processo, e, na que foi feita pelo réu, "aceitar e contestar o pedido".

Essa posição é sustentada, indistintamente e sem ressalvas, por ATHOS GUSMÃO CARNEIRO, ao considerar que os denunciados pelo autor e pelo réu, aceitando

165 Diante das alterações do instituto do sistema do Código de Processo Civil de 1939 para o de 1973 , deixando de ser "chamamento à autora" para transformar-se em "denunciação da lide", parece que faltou ao legislador precisão técnica ao tratar o denunciado como "litisconsorte". 
sua legitimidade na ação de regresso, "tornam-se litisconsortes do denunciante, sujeito portanto o denunciado à eficácia da coisa julgada na ação principal, além de naturalmente também sujeito à eficácia da coisa julgada na ação regressiva"166.

$\mathrm{Na}$ hipótese de se reconhecer que o denunciado assume a posição de litisconsorte $^{167}$, ele também será considerado parte na ação em que a sua intervenção foi provocada, dado que duas ou mais pessoas assumem, simultaneamente, a posição de autor ou de réu; está, portanto, sujeito à coisa julgada material de ambas as lides. De acordo com a regra do art. 191 do Código de Processo Civil, os litisconsortes, por constituírem procuradores diferentes, terão prazo em dobro para manifestarem-se ${ }^{168}$, ao passo que, em se tratando de litisconsórcio passivo, a contestação apresentada por um deles elide as consequências da revelia do outro litisconsorte (art. 320, I, do CPC).

Apesar da aparente obviedade da posição, deduzida a partir da leitura dos dispositivos legais, há diferentes prismas que devem ser analisados, até mesmo para reforçar ou repelir essa classificação.

O legislador pátrio utilizou a expressão "litisconsórcio" ao inspirar-se no modelo alemão, como corretamente destaca LUIZ FUX, ao ponderar o sentido que se lhe deve conferir. Ressalta que no sistema alemão, por não haver ação de regresso no mesmo processo, não há tecnicamente qualquer incongruência ${ }^{169}$.

\footnotetext{
166 Acrescenta, ainda, que, no Ciclo de Estudos de Processo Civil, realizado em agosto de 1983, resultou aprovada, por unanimidade, a tese por ele apresentada, com a seguinte conclusão: "A posição do denunciado pelo réu é, na ação principal, a de litisconsorte do denunciante, nos exatos termos do artigo 75, I, do CPC; em consequência, o autor, procedente a demanda principal, poderá executá-la também contra o denunciado, embora com atenção aos limites em que foi procedente a ação de direito regressivo e à natureza da relação de direito material" (Intervenção de terceiros, p. 151). Nesse mesmo sentido, Fredie Didier Júnior sustenta ser "inegável que o CPC deu ao denunciado poderes processuais equivalentes aos de um litisconsorte (e unitário repita-se), por isso que não nos parece que possa ser equiparado a um assistente simples - embora, reconheça-se, a lógica do raciocínio é correta" (Curso de Direito Processual Civil, v. 1, p. 356).

${ }^{167}$ Celso Agrícola Barbi diz que a única interpretação razoável é desdobrar a posição do denunciando, concluindo que, na ação principal, "ele poderá, pouco tecnicamente, assumir a posiçãa de litisconsorte", enquanto, na lide secundária, "ele assume a posição de réu" (Comentários ao código de processo civil, p. 348-349).

${ }^{168} \mathrm{O}$ prazo em dobro só se aplica com a formação do litisconsórcio, que se dá após o comparecimento do denunciado aos autos para assumir a sua condição de denunciado, na hipótese do art. 75, I, do CPC: cf. STJ, REsp 1.018.971-RJ, Rel. Min. TEORI ALBINO ZAVASCKI, $1^{\text {a }}$ Turma, DJe 24/11/2008; AgRg no Ag 499.632/RS, Rel. Min. ANTÔNIO DE PÁDUA RIBEIRO, $3^{\mathrm{a}}$ Turma, DJe 26/04/2004; REsp 594.875/SP,

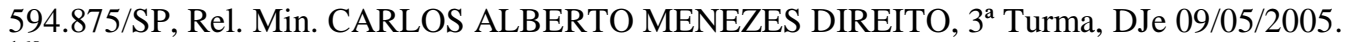

${ }^{169}$ Diz que a expressão "litisconsórcio", no sistema brasileiro, "deve ser entendida no plano ideal. Isto porque a derrota do denunciante é pressuposto da derrota do denunciado, daí pugnar este pela vitória daquele. É só nesse sentido de auxílio que se pode conceber um 'litisconsórcio', porque, sendo a denunciação verdadeira 
A falta de relação de direito material entre o denunciado e o adversário do denunciante é a principal crítica feita a essa corrente. A princípio, um não tem pretensão de direito material em face do outro ${ }^{170}$, de modo que, cientificamente, torna-se impróprio considerar que o denunciado ocupe a posição processual de litisconsorte do denunciante. Para que assim pudesse ser, imprescindível seria a existência de vínculo jurídico entre ambos.

Dessa forma, o denunciado não assumiria, a não ser pela interpretação literal do texto da lei, a posição de litisconsorte ${ }^{171}$. Ele será réu da demanda regressiva e não assumirá a posição de parte na ação principal, na qual conservará sua condição de terceiro, de modo que os efeitos da coisa julgada só se produzem em relação ao denunciado na lide secundária, da qual ele será parte. Assim, julgamos não ser possível considerá-lo litisconsorte unicamente porque as duas demandas serão decididas numa única sentença, até porque o julgador deverá resolvê-las em capítulos separados, julgando a ação e somente após, de maneira eventual, ou seja, dependendo do resultado da primeira, a denunciação da lide $^{172}$.

A questão também deve ser enfrentada pelo enfoque da dupla finalidade do instituto, que é o de o denunciado auxiliar a defesa do denunciante e a de garantir o ressarcimento deste. Por essa perspectiva, é evidente que o denunciado, como deve colaborar com a defesa dos interesses do denunciante, não está a defender direito próprio, não podendo ser alçado à posição de litisconsorte, mesmo porque, na ação principal, a tutela jurisdicional pleiteada não é contra ele, que também nada pede. Sua obrigação é de regresso, reembolsando o denunciante, de modo que, também por essa ótica, não pode ser

ação de regresso, o denunciado é adversário do denunciante e não co-litigante" (Intervenção de terceiros: aspectos do instituto, p. 38).

${ }^{170}$ Ressalvamos a hipótese em que a ação é ajuizada em face de mais de um réu, sendo que um deles denuncia a lide ao outro requerido, dado que possui, em tese, direito de ser indenizado pelo outro.

${ }^{171}$ Alexandre Freitas Câmara afirma que a denunciação da lide não gera litisconsórcio passivo entre o denunciante e o denunciado, de modo que não permite "a incidência do comando contido no parágrafo único do art. 46 do CPC” (Intervenção forçada de terceiros e responsabilidade civil do Estado, p. 24).

172 Oportunas as colocações de Gelson Amaro de Souza, ao afirmar "que não pode ser o denunciado considerado litisconsorte do denunciante, pois se litisconsorte fosse, poderia haver condenação de ambos, conjuntamente". Acrescenta, ainda, que "a sentença será uma só, já os pedidos serão julgados separadamente, um após o outro, sendo primeiro julgado o pedido da ação entre denunciante e seu adversário", de modo que essa circunstância "demonstra bem que entre denunciante e denunciado não existe litisconsórcio" (Cumprimento de sentença diretamente contra o denunciado, p. 17-18). 
colocado na posição de litisconsórcio, de vez que não será condenado a pagar diretamente ao adversário do denunciante.

Diante da falta de relação jurídica e do objetivo do denunciado auxiliar o denunciante, a posição do denunciado aproxima-se da do assistente, havendo entre ambos diversas características coincidentes. A principal delas relaciona-se à colaboração do denunciado na defesa dos interesses do denunciante, que consiste na própria natureza da assistência e numa das finalidades da denunciação, inspirada no direito germânico primitivo. Na realidade, o direito do terceiro não está diretamente em disputa, mas pode ser atingido, como acontece na denunciação da lide, pois o denunciado, se a ação principal for julgada procedente, pode ser condenado, em regresso, a reembolsar o denunciante por meio de decisão que lhe cause consequências jurídicas.

Acrescente-se, ainda, que não haverá, na ação principal, ampliação do objeto do processo, tal como não sucede também com a assistência, até porque a denunciação constitui ação regressiva, mas não propriamente defesa. Assim, a relação jurídica de direito material poderá ser debatida de maneira eventual na lide secundária, mas isso não amplia o objeto da principal, sendo certo, outrossim, que, apesar de não ser atingido pela coisa julgada, não lhe será possível discutir a justiça da decisão (art. 55 do CPC) ${ }^{173}$.

Com efeito, há uma confusão entre o tratamento conferido ao denunciado e os efeitos da sentença, como adverte DANIEL USTÁRROZ, ao destacar que "o que existe é uma equiparação dos efeitos da denunciação ao litisconsórcio", mas "não propriamente a formação de um litisconsórcio ulterior" ${ }^{, 174}$.

A reforçar a corrente de que a posição assumida pelo denunciado é efetivamente a de assistente, é certo que o terceiro, ainda que não fosse denunciado, poderia intervir

\footnotetext{
${ }^{173}$ No mesmo sentido, Cássio Scarpinella Bueno pensa que, "não obstante a letra da lei, o denunciado atua como assistente simples do denunciante e, nesta qualidade, ficará sujeito, se for o caso, ao que o art. 55 do CPC denomina 'justiça da decisão', mas que não se confunde com a coisa julgada. $\mathrm{O}$ denunciado, neste contexto, sujeita-se, apenas e tão somente, à coisa julgada derivada da sentença que julgar a 'ação regressiva', única em que ele é, invariável e inequivocamente, réu" (Partes e terceiros no processo civil brasileiro, p. 236).

${ }^{174}$ A intervenção de terceiros no processo civil brasileiro, p. 105.
} 
espontaneamente no processo, na condição de assistente ${ }^{175}$. Em vista da relação de direito material que possui com o denunciante, seu interesse jurídico não é apenas econômico, embora possa tornar-se preponderante, a depender do que for decidido. Seu interesse jurídico está em auxiliar o denunciante em sua defesa e evitar que seja condenado, em eventual ação de regresso, na hipótese de este sucumbir, o que se afina à assistência simples ${ }^{176}$. A intervenção do denunciado, assim, é voltada a colaborar para a defesa dos interesses do denunciante, sendo que, somente na hipótese de este sucumbir, poderá ter que reembolsá-lo nos limites da sua obrigação, por meio de ação de regresso.

Além disso, a relação jurídica poderá ser afetada, porém não de maneira direta e imediata, o que aproximaria, de outro lado, a denunciação da lide da assistência litisconsorcial, mas somente de maneira reflexa e mediata, pois não se debate, na lide principal, a relação jurídica da qual o denunciado é titular. Ele auxiliará o denunciante, procurando não ser prejudicado de maneira reflexa pela futura sentença, em vista da possibilidade de afetar-se aquela relação jurídica.

Apesar de o denunciado assumir a posição de assistente, pondere-se que se trata, na verdade, de uma assistência anômala, dado que a intervenção do denunciado não é espontânea, mas provocada.

De maneira temperada, ARRUDA ALVIM considera que, "na verdade, a posição do denunciado não é, ontologicamente, a de litisconsorte”. Ressalta que o denunciado tem interesse que o denunciante "seja vencedor na ação principal, para que a denunciação da lide reste prejudicada" e conclui que "o denunciado tem interesse próprio de assistente simples (art. 50), mas atua com poderes de litisconsorte em razão de disposição legal expressa nesse sentido"

\footnotetext{
${ }^{175}$ Maria Berenice Dias sustenta que, "em não havendo a denunciação, o integrante da relação dependente pode espontaneamente participar da demanda como assistente, nos precisos termos do art. 50 do CPC" $(O$ terceiro no processo, p. 124).

${ }^{176}$ Nesse sentido, oportunas as considerações de Cássio Scarpinella Bueno, ao afirmar que, ainda que não haja denunciação, "é possível que o terceiro (que poderia ter sido denunciado mas não o foi) intervenha no processo. Nesta hipótese, assumirá, inequivocadamente, a posição de assistente simples. Seu interesse jurídico para tanto deriva da perspectiva de se ver acionado por quem poderia ter denunciado, desde que vencido, em ação de regresso" (Partes e terceiros no processo civil brasileiro, p. 236-237).

${ }^{177}$ Comentários ao código de processo civil, nota 1 ao art. 74, p. 139.
} 
Impõe-se, outrossim, enfrentar a posição da denunciação na ação principal pela ótica das hipóteses legais do art. 70 do Código de Processo Civil, em vista de cada uma delas possuir características próprias.

No caso do inciso I, do art. 70, é certo que o denunciado não tem qualquer relação jurídica com a parte contrária do denunciante, de vez que o alienante não tem vínculo com o adquirente de negócio jurídico realizado posteriormente. O mesmo sucede na hipótese do inciso III, dado que aquele que estiver obrigado a indenizar o prejuízo do denunciante não tem liame com o adversário deste, como ocorre, por exemplo, com o segurador, que não tem ligação com aquele, mas apenas com o denunciante que o contratou. Dessa maneira, a posição do denunciado assemelha-se à do assistente.

A situação altera-se na hipótese do inciso II, do art. 70. O denunciado detém a propriedade ou a posse indireta e o denunciante, a posse direta, de modo que aquele tem vínculo, ainda que não diretamente, mas transverso, com o adverário deste, por força do direito material tutelado. Em vista das particularidades de direito material decorrentes da bipartição do exercício da posse, o possuidor indireto ou o proprietário têm, na realidade, ligação com a parte adversa do possuidor direto.

É o que sucede, por exemplo, no caso de imóvel que, após ser reformado pelo proprietário e ter seu muro elevado, foi alugado, causando danos ao vizinho, ao impedir que o sol incidisse sobre a piscina dele. Amparado no direito de vizinhança relativo ao uso nocivo da propriedade, o proprietário do imóvel vizinho (autor) ajuiza ação de nunciação de obra nova em face do locatário (possuidor direto), que denuncia a lide ao locador, proprietário do bem. É inegável, pois, a ligação que o locador tem com o proprietário do imóvel vizinho, que fora prejudicado em decorrência de a obra realizada ter impedido o sol de aquecer sua piscina.

Diante dessa perspectiva, SYDNEY SANCHES reconhece que o denunciado é assistente do denunciante nas hipóteses dos incisos I e III, mas considera-o litisconsorte, nos casos do inciso $\mathrm{II}^{178}$. Reputamos correta a classificação da posição do denunciado

${ }^{178}$ Sustenta não haver "seja na hipótese do art. 74, seja na do art. 75 , se se tratar de qualquer dos casos previstos nos itens I e III do art. 70, litisconsórcio propriamente dito entre o litisdenunciante e o litisdenunciado. Este (o litisdenunciado) não tem pretensão própria contra o adversário do denunciante. Nem 
como assistente simples quanto às hipóteses dos incisos I e III, porém a do inciso II identifica-se, de modo técnico, mais precisamente com o assistente litisconsorcial, mas não com o litisconsorte ${ }^{179}$. Possivelmente, essa referência ao litisconsorte decorre da previsão do art. 54 do Código de Processo Civil, que estabelece que o assistente litisconsorcial é considerado litisconsorte da parte principal.

É certo que o objeto do processo não será o direito do assistente litisconsorcial, mas a decisão a ser proferida tem potencial para atingir os seus próprios interesses. É o que sucede, por exemplo, com o usufrutuário, na hipótese de o nu-proprietário ser vencido na ação reivindicatória que lhe é promovida, bem como em todas as hipóteses em que ocorre o desdobramento da relação possessória, decorrente da relação jurídica mantida entre o possuidor direto e o indireto.

Como a sentença, numa ação em que litigam o possuidor direto e o turbador, poderá atingir, reflexamente, o possuidor indireto, diante do vínculo de direito possessório existente, a posição jurídica deste equipara-se à do assistente litisconsorcial, por força do vículo jurídico distinto, se comparado com as outras hipóteses de denunciação ${ }^{180}$.

Ao tratar das hipóteses de cabimento da assistência litisconsorcial, THEREZA ALVIM exemplifica justamente com o caso do usufrutuário, que vê o imóvel ser reivindicado do nu-proprietário, que o deu em usufruto e reporta-se à situação em que o terceiro é atingido pela decisão, em vista de ter "relação jurídica, atual ou potencial, com a parte contrária àquele que tencione assistir”. Diante deste estudo específico sobre a assistência litisconsorcial, que não se preocupou em associá-lo com a denunciação da lide,

tem o adversário do denunciante (na ação principal) pretensão de direito material contra o denunciado". Acrescenta, ainda, que, "nas hipóteses do inc. II, como a posse direta do litisdenunciante emana da posse do litisdenunciado (que, afora isso, mantém a indireta), aí sim se pode dizer que há litisconsórcio entre um e outro perante o adversário do denunciante na causa principal, quando nesta se colima a posse integral" (Denunciação da lide no direito processual civil brasileiro, p. 206-207).

179 A partir do conceito de que litisconsórcio, no sentido de haver pluralidade de partes no polo ativo ou passivo da relação processual, que possuem a qualidade de autoras ou de rés no mesmo processo, por pleitearem direito, em nome próprio.

${ }^{180}$ Ao afirmar que as posses direta e indireta coexistem e não colidem, Caio Mário da Silva Pereira afirma que "contra o terceiro que levante uma situação contrária, pode o possuidor direto invocar proteção possessória, como igualmente o possuidor indireto, sem que haja mister convocar o auxílio ou assistência do outro. Cada um, ou qualquer um - defende a posse como direito seu, por título próprio, e independentemente do título do outro" (Instituições de direito civil, v. IV, n. 287, p. 27). Essa posição jurídica amolda-se, pois, à assistência litisconsorcial. 
só se reforça nossa convicção sobre a posição do denunciado, entendido, nos casos do inciso II, do art. 70, do texto processual, como assistente litisconsorcial ${ }^{181}$.

Assim, consideramos que o denunciado assume a posição de assistente simples nos casos de denunciação da lide fundada nas hipóteses dos incisos I e III, do art. 70, do Código de Processo Civil, por força da falta de vínculo jurídico com a parte adversa do denunciante e da finalidade marcante do instituto de auxiliar o denunciante na defesa de seus interesses. Será, de outro lado, assistente litisconsorcial, no caso do inciso II.

Ponderamos, outrossim, que a posição predominante dos doutrinadores é a de reconhecer que o denunciado assume a posição processual de assistente ${ }^{182}$, por força do vínculo jurídico de direito material, afastando-se da interpretação literal da lei e valorizando a interpretação sistemática.

Feitas essas ponderações, parece-nos que deve ser tido o denunciado como assistente simples ${ }^{183}$, não, portanto, litisconsorcial, exceto no caso de possuidor direto e indireto, havendo, todavia, posição genérica em sentido diverso ${ }^{184}$. Essa definição não se revela de menor importância, em vista de a atuação do assistente simples ser limitada e subordinada à do assistido, ao contrário do que se dá com o assistente litisconsorcial, que pode, inclusive, praticar atos contrários à vontade daquele, posicionando-se em sentido

\footnotetext{
${ }^{181}$ Da assistência litisconsorcial no Código Brasileiro, p. 1080.

182 Cândido Rangel Dinamarco considera que "qualquer que seja sua reação ou seu comportamento comissivo ou omissivo, o denunciando será sempre assistente do denunciante e, simultaneamente, réu na demanda que este lhe move" (Instituições de direito processual civil, v. II, n. 606, p. 408). Também nesse sentido, Cássio Scarpinella Bueno (Partes e terceiros no processo civil brasileiro, p. 236); Daniel Amorim Assumpção Neves (Intervenção de terceiros e revelia, p. 34); José Manoel de Arruda Alvim Netto e outros (Comentários ao código de processo civil, nota 1 ao art. 74 do CPC, p. 139); Ovídio de Araújo Baptista da Silva (Comentários ao Código de Processo Civil, p. 350); Rodrigo Salazar (Denunciação da lide, p. 97); Sebastião de Oliveira Castro Filho (Da evicção no direito brasileiro, p. 205); Vicente Greco Filho (Da intervenção de terceiros, p. 41-42); e William Santos Ferreira e Flávio Cheim Jorge (Denunciações da lide sucessivas - possibilidade - condenação direta e exclusiva dos denunciados, p. 313).

${ }^{183}$ Ovídio de Araújo Baptista da Silva sustenta "que o denunciado será sempre assistente simples do denunciante, nunca seu litisconsorte" e ressalta que "não é o processo que dirá quem são os litisconsortes na demanda reivindicatória, assim como não lhe cabe prescrever quem são as partes e, conseqüentemente, quem serão os litisconsortes na ação de indenização que a vítima promover contra o causador do dano" (Comentários ao Código de Processo Civil, p. 350-352).

${ }^{184}$ Parecendo estar mais preocupado em afastar a posição de litisconsorte do que a de defender efetivamente que o denunciado é assistente litisconsorcial, Cândido Rangel Dinamarco afirma que a assistência é qualificada, ao explicar que "isso significa que, na mesma medida da assistência litisconsorcial descrita pelo art. 54 do Código de Processo Civil como figura geral, também aqui a assistência a ser prestada pelo denunciado ao denunciante abre-se num conjunto muito rico de possibilidades de participação. Mesmo assim, o assistente litisconsorcial é sempre um assistente e nunca um litisconsorte" (Intervenção de terceiros, v. II, p. 165).
} 
oposto, bem como postulando produção de prova e recorrendo, mesmo que o assistido assim não atue.

Dessa maneira, consideramos que, nas hipóteses dos incisos I e III, do art. 70, do Código de Ritos, o denunciado assume a posição de assistente simples, enquanto que, no caso do inciso II, será assistente litisconsorcial. 


\section{DAS HIPÓTESES DE CABIMENTO DE DENUNCIAÇÃO DA LIDE}

5.1. Da previsão do art. 70 do CPC. O legislador processual de 1973 ampliou, em relação ao Código de 1939, as hipóteses de cabimento da denunciação da lide, não só restringindo-a à evicção, mas também estendendo-a para todas as hipóteses de regresso. Assim, a lide regressiva pode estar fundada tanto em direito real, como em direito pessoal.

Foram separadas as hipóteses de denunciação, distribuindo-as pelos três incisos do art. 70 do texto processual. Apartaram-se os casos de direito de indenização por perda de domínio e perda de posse direta, bem como se ampliou o instituto, ao prever hipótese ampla que permite aplicá-lo sempre que o terceiro possa ser responsabilizado, por força de lei ou de contrato, pelos prejuízos sofridos por alguém no processo.

$\mathrm{O}$ art. 70 do Código de Processo Civil estabelece, de maneira expressa, as três hipóteses de denunciação da lide: ao alienante, na ação em que terceiro reivindica a coisa, cujo domínio foi transferido à parte, a fim de que esta possa exercer o direito que da evicção lhe resulta; ao proprietário ou ao possuidor indireto quando, por força de obrigação ou direito, em casos como o do usufrutuário, do credor pignoratício ou do locatário, o réu, citado em nome próprio, exerça a posse direta da coisa demandada; àquele que estiver obrigado, pela lei ou pelo contrato, a indenizar, em ação regressiva, o prejuízo do que perder a demanda. Estão contempladas pela lei a garantia própria - a que decorre da transmissão de um direito, como, por exemplo, a evicação - e a imprópria - caso não exista uma transmissão de direito, como sucede no seguro, não sendo, pois, verdadeira garantia, mas simples obrigação de indenizar.

Como adverte CÂNDIDO RANGEL DINAMARCO, mesmo quando configurada uma dessas três hipóteses, a admissibilidade da denunciação da lide depende sempre "da implementação de certos pressupostos formais, como o modo de deduzi-la, tempestivamente etc; depende também, como é óbvio, da presença dos pressupostos de 
admissibilidade do julgamento do mérito, de aplicação geral em todo o sistema processual" 185 .

A garantia própria, decorrente da transmissão de direitos, em que se discute a obrigação legal ou contratual do denunciado, é tratada nos incisos I e II, bem como em algumas hipóteses do inciso III, ao passo que a garantia imprópria se dá nos casos de responsabilidade civil, na previsão do inciso III, por constituir simples obrigação de indenizar.

5.1.1. Da denunciação da lide nos casos de evicção. O inciso I, do art. 70, do Código de Processo Civil autoriza a denunciação da lide ao alienante, na ação em que terceiro reivindica a coisa, cujo domínio foi transferido à parte, para que exerça o direito que da evicção lhe resulta.

Essa é a clássica e tradicional hipótese de denunciação da lide, para atendimento da qual o instituto surgiu, associado, portanto, à responsabilidade pela evicção, disciplinada no art. 447 e seguintes do Código Civil, ao dispor sobre os contratos onerosos, estabelecendo que o alienante responde por ela.

Evicção é a perda de um bem pelo adquirente, por força de sentença judicial, que reconheça a terceiro direito sobre a coisa ${ }^{186}$. Admite-se, outrossim, que a perda da coisa decorra de ato legítimo de autoridade, mas não necessariamente de uma decisão judicial ${ }^{187}$. Dessa maneira, para o exercício resultante da evicção, além da sentença judicial, o ato da autoridade que prive o adquirente da propriedade ou do uso da coisa é suficiente, não sendo imprescindível obter o lesado uma sentença declarando a perda do bem. Caso fosse necessária a decisão judicial, o instituto da denunciação perderia seu próprio sentido e deixaria de ser efetivo.

\footnotetext{
${ }^{185}$ Intervenção de terceiros, n. 80, p. 158.

${ }^{186}$ Cf. Clóvis Bevilaqua, ao dizer que a "evicção é a perda total ou parcial de uma coisa, em virtude de sentença, que a atribui a outrem, por direito anterior ao contrato, de onde nascera a pretensão do evicto" (Código Civil dos Estados Unidos do Brasil, p. 221, anotação ao art. 1.107).

${ }_{187}$ Cf. Athos Gusmão Carneiro, ao ressaltar não ser exigível uma sentença, em vista de a intenção do legislador ser a de evitar o conluio entre o comprador e um terceiro, em prejuízo do vendedor. Exemplifica que a evicção não pressupõe sentença, bastando "que o adquirente fique dela privado por ato legítimo de autoridade, tal como no caso de apreensão por se tratar de res furtiva ou de contrabando" (Intervenção de terceiros, p. 111).
} 
A aquisição de quem perde o bem deve ter-se dado por meio de contrato oneroso, nos termos do art. 447 do Código Civil, compreendendo, inclusive, a aquisição ocorrida em hasta pública. Tanto se impõe já que ao adquirente cabe ter o bem livre e desembaraçado, a fim de exercer sobre ele o domínio. A noção da evicção está ligada, pois, à ideia de que o alienante deve assegurar o negócio jurídico e a origem da coisa, a fim de o adquirente não ser prejudicado.

Para se configurar a responsabilidade do alienante pela evicção, não é necessário que a perda da propriedade, posse ou uso da coisa alienada seja total, dado que, se o bem não estiver em perfeitas condições de uso, a responsabilidade também existe, conferindo-se a ele mais de uma opção para a solução. Assim, de acordo com o art. 455 do Código Civil, se a perda parcial for considerável, o evicto poderá optar entre a rescisão do contrato e a restituição de parte do preço correspondente ao desfalque sofrido; no caso de a perda não ser considerável, porém, caberá apenas direito à indenização, preservando-se o negócio jurídico. Questão difícil é definir no que consiste a perda considerável da coisa, entendida como sendo aquela que compromete a finalidade para a qual o bem se prestaria: está, portanto, mais associada à qualidade e à natureza do que propriamente à quantidade do bem perdido ${ }^{188}$.

Além disso, a causa da perda do bem deve ser anterior à alienação; se for posterior, o alienante não terá qualquer responsabilidade ${ }^{189}$, pois o vício que levou à perda do bem não terá sido decorrência de sua conduta.

\footnotetext{
${ }^{188}$ São corriqueiros, na doutrina, os exemplos de que seria considerável a perda de uma fração relativamente pequena de um imóvel, onde está situada a sede da fazenda ou a nascente de água ou o rio, que é utilizado para o gado beber água. De outro lado, a evicção não é entendida como considerável, embora quantitativamente o fosse, se houvesse a perda de 60 alqueires de um imóvel composto de 100 alqueires, desde que o desfalque estivesse ligado à fração que não prejudicasse a finalidade do bem ou a sua utilização e exploração.

${ }^{189}$ Com propriedade, Caio Mário da Silva Pereira afirma que o alienante não teria responsabilidade, "em caso de usucapião iniciado antes e completado depois da transmissão ao adquirente", pois estava "nas mãos do adquirente interromper a prescrição", de modo que "não pode atribuir ao alienante as consequências de ter deixado de fazê-lo e tolerado a continuação de uma posse prejudicial ao seu direito". Ele ressalva apenas hipótese em que "o prazo prescricional se completa tão próximo do ato de aquisição que não haja tempo para que o adquirente conheça a situação e a interrompa" (Instituições de direito civil, v. III, n. 209, p. 81). Também oportuno o exemplo de Carlos Roberto Gonçalves ao tecer considerações sobre a desapropriação pelo Poder Público e explicar que, se a causa da perda surgiu após a transmissão do direito, nenhuma responsabilidade cabe ao alienante, mas, "se já havia sido expedido decreto de desapropriação antes da realização do negócio, responde o alienante pela eviç̧ão, ainda que a expropriação se tenha efetivado posteriormente, porque a causa da perda é anterior ao contrato e o adquirente não tinha meios de evitá-la" (Direito civil brasileiro, p. 123).
} 
A responsabilidade pela evicção pode ser prevista por cláusula expressa, reforçando, diminuindo ou excluindo a responsabilidade (art. 448 do CC). Todavia, essa cláusula, por si só, não afasta a responsabilidade do alienante, dado que o evicto, se não souber do risco da evicção ou não o assumir, apesar de informado, tem o direito de receber o preço que pagou pelo bem (art. 449 do CC) a fim de não caracterizar enriquecimento sem causa do alienante.

Na hipótese de cláusula de exclusão de responsabilidade e de o evicto assumir esse risco, inútil será o adquirente denunciar a lide ao alienante, em vista de não lhe trazer qualquer benefício. Isso porque se previu que o alienante não teria responsabilidade, assumindo o adquirente todos os riscos - o que é plenamente viável por se tratar de direito disponível - de modo que as partes podem convencionar livremente em contrato.

Caso a responsabilidade pela evicção não seja excluída ou o adquirente não assuma os riscos consequentes, aquele que transferiu a propriedade, a posse ou o uso da coisa deve garantir o direito do adquirente, assegurando o uso e a fruição do bem. Cuida-se de responsabilidade atinente ao negócio celebrado, essencial ao contrato, decorrente de lei.

Se nada for previsto e a evicção ocorrer, não conhecendo ou não assumindo o evicto os riscos consequentes, terá direito a ser restituído do valor integral pago, se a evicção for total, ou do valor proporcional, caso ela seja parcial. Além disso, será indenizado pelos frutos que tiver sido obrigado a restituir, pelas despesas dos contratos, pelos prejuízos que diretamente resultaram da evicção e, ainda, pelas custas judiciais e pelos honorários do advogado por ele constituído (arts. 449, 450 e 451 do CC).

Importante destacar, como será aprofundado em outro capítulo, que o adquirente, para poder exercitar o direito que da evicção lhe resulta, deve, segundo a norma do Código Civil, "notificar do litígio o alienante imediato, ou qualquer dos anteriores, quando e como lhe determinarem as leis do processo" (art. 456 do CC). Esse "notificar do litígio" nada mais é que a realização da denunciação da lide, tanto que a notificação deverá dar-se "quando e como" determinar a lei de processo. O termo era também usado pelo Código Civil de 1916 (art. 1.116). 
O momento para notificar (denunciar a lide) dependerá da posição do denunciante na demanda: deverá ser requerida, juntamente com a do réu, na petição inicial, se o adquirente for o autor; e, no prazo para contestar, se o adquirente for o réu (art. 71 do CPC). Caso não cumpra essa previsão, esse adquirente perderá, pela interpretação literal da lei, a garantia contra os riscos da evicção, pois tal previsão está sendo colocada como pressuposto para o exercício do direito.

Feitas essas considerações atinentes ao direito material, a redação do inciso I, do art. 70, do Código de Processo Civil revela-se imprecisa, ao estabelecer que o alienante será denunciado, "na ação em que terceiro reivindica a coisa, cujo domínio foi transferido à parte, a fim de que esta possa exercer o direito que da evicção lhe resulta". Ao reportar-se ao termo terceiro, a redação do dispositivo pode gerar desnecessária confusão e dificultar sua aplicação, notadamente porque está cuidando-se de um instituto de intervenção de terceiros.

Na realidade, quem reivindica a coisa é o autor, que é parte no processo e não o terceiro. O terceiro, processualmente, será o alienante, a quem a lide será denunciada, a fim de auxiliar o denunciante a provar a regularidade do negócio jurídico e, na hipótese de este sucumbir na ação principal, indenizar, na ação regressiva, se for o caso, o prejuízo decorrente da evicção.

Em vista de o legislador não ter realizado qualquer distinção, a denunciação pode ser feita tanto pelo autor como pelo réu, sempre que ao adquirente puder resultar a perda da coisa. Caso o adquirente seja o autor, ele promoverá a ação em face do ocupante do imóvel e denunciará a lide ao alienante. Na hipótese de o adquirente ser o réu em ação promovida pelo reivindicante, ele deverá denunciar a lide ao alienante, a fim de proteger-se dos riscos da evicção.

O inciso I refere-se à reivindicação, de modo que se faz necessário tratar da ação reivindicatória, cujos elementos que a ensejam se encontram estabelecidos no art. 1.228 do Código Civil, dispondo: "O proprietário tem a faculdade de usar, gozar e dispor da coisa, e o direito de reavê-la do poder de quem quer que injustamente a possua ou detenha". Ao conceituar a ação reivindicatória, PAULO TADEU HAENDCHEN destaca as seguintes características: "é uma ação de natureza real, porque fundada no domínio"; "objetiva a 
retomada da coisa que se acha em poder de terceiro, por qualquer título"; e "a detenção ou a posse do terceiro deve ser injusta para que haja a retomada" ${ }^{\prime 190}$.

O texto legal refere-se, quanto a essa intervenção de terceiro, apenas ao adquirente que reivindica a coisa, cujo domínio foi transferido. Sua interpretação literal conduz a essa conclusão, mas a questão é extremamente polêmica e enseja muita discussão na doutrina.

No sentido de que o Código de Processo Civil de 1973 restringiu o âmbito de aplicação do instituto aos casos de reivindicação, sustenta ANTONIO CARLOS DE ARAÚJO CINTRA que se retomou "a tradição que vinha de Pereira e Souza, Teixeira de Freitas e João Mendes Júnior”, contrariando a posição, então, dominante ${ }^{191}$.

Ocorre, no entanto, que o adquirente pode perder a coisa, total ou parcialmente, não apenas por meio da ação reivindicatória ${ }^{192}$. Na realidade, sempre que a sentença a ser proferida puder afetar o direito do adquirente, a denunciação deve ser admitida. A evicção não se limita apenas à perda do direito de domínio, mas também à perda do direito de posse e do direito de uso, como estabelecia o art. 1.107 do Código Civil de $1916^{193}$. No caso, importante destacar que estamos considerando apenas as hipóteses em que a posse não se desdobra em posse direta e indireta, como é regulada no inciso II, do art.70, do Código de Processo Civil.

Com justeza, ARRUDA ALVIM afirma não ser correto realizar interpretação literal do inciso I, dado que "o que é relevante é a declaração jurídica”. Critica a influência do legislador processual pela terminologia e tradição civilista, em vista de o verbo "reivindicar" ser tipicamente da nomenclatura da classificação de ações, oriunda de direito

\footnotetext{
${ }^{190}$ Ação reivindicatória, p. 18.

${ }^{191}$ Do chamamento à autoria, p. 172. Esclarece-se que o autor escreveu referido livro em 1971, conquistando a livre-docência de Direito Processual Civil na Faculdade de Direito da Universidade de São Paulo, porém, antes de publicá-lo, adaptou-o ao Código de Processo de Civil de 1973.

${ }^{192}$ Orlando Gomes afirma haver três formas de evicção: a reivindicatória, a expropriatória e a resolutória. Para identificá-las, diz que a reivindicatória "resulta da sentença que julgou procedente a ação de reivindicação do proprietário da coisa vendida; expropriatória, quando o bem, já penhorado, quando foi vendido, vem a ser alienado em hasta pública; resolutória, se a precedente aquisição do vendedor se resolve por estar subordinada a uma condição resolutiva" (Contratos, n. 71, p. 97).

193 A redação foi alterada para o Código Civil de 2002, tratando dos contratos onerosos no art. 447, que suprimiu a referência à transferência do domínio, posse ou uso. Apesar dessa alteração, não é possível associar a evicção apenas à perda do domínio.
} 
material; acrescenta, ainda, que a evicção pode tanto emergir da ação declaratória positiva como da negativa ${ }^{194}$.

No mesmo sentido, CELSO AGRÍCOLA BARBI reputa ser inadmissível limitar a denunciação apenas à hipótese de ação para reivindicação, até porque o bem pode ser perdido em decorrência de outras ações. Arrola, para exemplificar, várias hipóteses, como ação declaratória proposta pelo proprietário e possuidor contra aquele que se disse verdadeiro proprietário; ação possessória proposta contra o adquirente; ação reivindicatória proposta pelo adquirente; ação de usucapião que atinja a coisa ou parte dela; bem como ação confessória ou negatória de servidão sempre quando "houver evicção parcial, que ocorre com o reconhecimento de servidão sobre o imóvel, ou pelo desconhecimento, isto é, negativa de servidão em seu favor" ${ }^{\prime 195}$.

Assim, consideramos que a interpretação do inciso I, do art. 70, do texto processual deve ser ampliativa, admitindo-se a denunciação da lide tanto na ação reivindicatória, como também sempre que o adquirente puder perder, total ou parcialmente, o domínio, a posse e o uso da coisa adquirida em demanda judicial, qualquer que seja sua natureza, ou em decorrência de ato de autoridade.

5.1.2. Da denunciação da lide pelo possuidor direto. Estabelece o inciso II, do art. 70, do Código de Processo Civil a hipótese de o proprietário ou o possuidor indireto ser denunciado quando o réu exerce apenas a posse direta da coisa demandada. Dispõe que o possuidor direto poderá chamar o terceiro "em casos como o do usufrutuário, do credor pignoratício, do locatário", não podendo esse inciso, porém, ser considerado como enunciado limitado, mas exemplificativo, tanto que utiliza a expressão "em casos como" $" 196$.

\footnotetext{
${ }^{194}$ Exemplifica, também, que o comprador pode, diante de uma situação de incerteza jurídica, mover ação declaratória negativa contra quem se intitula proprietário da mesma coisa e denunciar a lide ao alienante. No caso de a ação ser julgada procedente, o julgador, além de declarar que o réu não é o proprietário, terá que declarar que a propriedade é do autor (Código de processo civil comentado, p. 244-245).

${ }^{195}$ Comentários ao Código de Processo Civil, p. 335-336. Também contrário à interpretação literal: Sydney Sanches, Denunciação da lide no direito processual civil brasileiro, p. 72-73.

${ }^{196}$ Como assevera Cândido Rangel Dinamarco, o dispositivo tem caráter meramente exemplificativo e considera possuidores diretos, entre outros, o depositário, o comodatário, o usuário, o titular do direito real de habitação, o enfiteuta, o promissário-comprador e o testamenteiro ou o inventariante, "sendo todos eles admitidos, como tais, a denunciar a lide ao possuidor indireto" (Intervenção de terceiros, n. 82, p. 182).
} 
Em vista de a posse ser desdobrada em duas e ser exercida por sujeitos diversos, sendo que ambos têm direito sobre a coisa demandada, o possuidor direto, sendo demandado, pode chamar o proprietário ou o possuidor indireto. É o que sucede, portanto, na relação jurídica do nu-proprietário e usufrutuário, do locador e locatário, do credor pignoratício e titular do domínio da coisa dada em garantia, do comodante e comodatário. Essa previsão decorre da regra do art. 1.197 do Código Civil ${ }^{197}$, que estabelece não ser possível a posse direta anular a indireta, de quem aquela foi havida, podendo o possuidor direto, inclusive, defender a sua posse contra o indireto, tudo a depender do conteúdo da demanda.

O possuidor indireto tem o animus domini, que o possuidor direto não tem, mas é certo que as duas posses coexistem simultaneamente, havendo mero desdobramento da relação possessória ${ }^{198}$.

Sempre que a posse desdobrar-se e o proprietário ou o possuidor indireto tiver a obrigação de indenizar no caso de derrota do possuidor direto, este terá o ônus de denunciar aquele, por força da obrigação de garantir a posse direta ou de ressarcir os prejuízos, no caso de o possuidor direto perder a posse do bem.

Os dois objetivos dessa hipótese de denunciação da lide são evidentes: possibilitar que o denunciado defenda sua propriedade ou a posse direta, bem como que o possuidor indireto busque, por meio de ação de regresso, indenização do que lhe será devido caso a ação principal seja julgada procedente.

\footnotetext{
${ }^{197}$ O art. 486 do Código Civil de 1916 já estabelecia que a posse direta não excluía a posse indireta.

${ }^{198}$ Cf. Caio Mário da Silva Pereira, ao dizer que "as posses direta e indireta coexistem; não colidem nem se excluem. Ambas, mediata e imediata, são igualmente tuteladas" (Instituições de Direito Civil, v. IV, n. 287, p. 27); Silvio de Salvo Venosa, ao afirmar que "as posses direta e indireta convivem harmoniosamente e não colidem", de modo que "essas duas modalidades podem coexistir sem afetar os fundamentos estruturais da posse" (Direito civil: direitos reais, p. 65-69); Francisco Eduardo Loureiro, ao dizer que "as duas posses coexistem em planos diferentes, sem contradição entre si", sendo que "tanto o possuidor direto como o indireto podem afastar os ataques injustos de terceiros à posse, utilizando a tutela possessória e o desforço próprio" (Código civil comentado, coord. Cezar Peluso, p. 1.137). Pondera-se, no entanto, que essa bipartição do exercício da posse não se amolda às tradicionais teorias de Savigny, dado depender a posse do animus de ser dono, e de Jhering, ao considerar necessária a exteriorização do domínio, o que, todavia, não sucede com os possuidores indiretos.
} 
Diante desses objetivos, fica claro que a postulação do possuidor direto só pode ser exercida se a sua condição for fruto de um contrato oneroso, dado que, se fosse gratuito, não seria cabível cogitar indenização. A essa conclusão também se pode chegar por meio da aplicação analógica do disposto no art. 447 do Código Civil, que, ao tratar da evicção, estabelece que por ela deve responder o alienante nos contratos onerosos.

Assim, por força de o comodato constituir empréstimo gratuito de coisas não fungíveis, nos termos do art. 579 do Código Civil, afasta-se a aplicação do inciso II, do art. 70, do Código de Processo Civil, sendo obrigatória, neste caso, a nomeação à autoria, com indicação pelo comodatário do comodante. Acrescente-se que não há qualquer direito à indenização, dado que "o comodatário não poderá jamais recobrar do comodante as despesas feitas com o uso e gozo da coisa emprestada", conforme dispõe o art. 584 do Código Civil; eventuais benfeitorias, outrossim, devem ser consideradas despesas feitas para uso e gozo da coisa emprestada, até porque o comodatário é obrigado a conservá-la como se sua própria fosse (art. 582 do CC) ${ }^{199}$.

Parece-nos acertada a ressalva de SYDNEY SANCHES, ao considerar que cabível é a denunciação da lide ao comodante, a fim de ele garantir apenas a posse do comodatário, caso se tenha comprometido expressamente a garantir-lhe a posse direta por tempo determinado e o comodatário fique exposto a perder a posse antes desse prazo estabelecido, por força da ação de terceiro ${ }^{200}$.

Como destacado no item anterior, discordamos da interpretação literal de que a previsão do inciso I, do art. 70, do texto processual não abrange todos os casos de evicção,

199 "REINTEGRAÇÃO DE POSSE - Posse da autora comprovada - As despesas com conservação e uso da coisa dada em comodato não são passíveis de indenização ou retenção por benfeitorias - Recurso improvido." (TJSP, AP 9193775-17.2006.8.26.0000, 21ª Câmara de Direito Privado, Rel. SILVEIRA PAULILLO, J. 11/04/07).

${ }^{200}$ Cf. Denunciação da lide no direito processual civil brasileiro, p. 85 . Em sentido mais amplo quanto ao cabimento da denunciação, do qual discordamos, Ovídio Araújo Batista da Silva afirma que "o comodante tem posse direta", de modo que "a obrigação de assegurar o uso pacífico da coisa dada em comodato é dever que o comodante assume implicitamente, por força do contrato". Conclui, ainda, que "o comodatário deverá denunciar a lide ao comodante, para sujeitá-lo ao efeito de intervenção do art. 55, mas a ação de indenização será proposta não como ação preventiva, para o caso de eventual sucumbência do denunciante, mas sim como ação que terá a sucumbência como pressuposto" (Comentários ao Código de Processo Civil, p. 337/338). Esse raciocínio nos parece contraditório, diante do verdadeiro sentido de denunciação, de modo que não haveria justificativa para denominar a intervenção de terceiro de denunciação da lide, enquanto que o objetivo, no caso, limitar-se-ia apenas ao auxílio na defesa, inexistindo, ainda, duas ações que seriam resolvidas no mesmo processo. Além disso, a previsão do art. 584 do CC eliminaria qualquer direito à indenização. 
mas apenas aqueles que são objeto de ação voltada à reivindicação a respeito do domínio. De qualquer maneira, caso assim se considere e como a evicção também pode ocorrer pela perda da posse - não contemplada na previsão do inciso I - entendemos, pelo fato de a previsão do inciso II ser meramente exemplificativa, que aquele que recebe a posse ou o uso de uma coisa também deve ser resguardado de evicção resultante de contrato oneroso, de modo que a hipótese se enquadra no disposto do inciso $\mathrm{II}^{201}$.

A denunciação, por outro lado, não será admissível, se o possuidor indireto estiver desobrigado por lei ou por contrato. Essa restrição à responsabilidade é plenamente cabível, até porque o requerido não é surpreendido, em vista de estar ciente da existência desse risco. Se constar essa previsão contratual e o requerido aceitá-la, não pode alegar sequer eventual prejuízo, até mesmo porque possivelmente houve compensação contratual, como, por exemplo, o abatimento no valor do negócio; dessa forma, se houver denunciação, ela estará fadada à improcedência.

Importante destacar que não há de se confundir essa hipótese de denunciação da lide com a nomeação à autoria ${ }^{202}$, dado que o possuidor direto tem direito ou obrigação em relação ao bem, diferentemente do que se dá na nomeação, em que o nomeante é mero detentor $^{203}$. Além disso, não há a substituição do réu no polo passivo, sendo que ambos têm o ônus de defender a coisa demandada e o possuidor direto tem, desde logo e mediante ação regressiva contra o denunciado, oportunidade de pleitear, fundado nos direitos que decorrem de seu contrato, indenização que lhe é devida, na hipótese de o seu direito ser atingido e a ação principal, julgada procedente.

O sistema processual confere tratamento diverso para essas duas modalidades de intervenção de terceiro. Se o réu é mero detentor, deverá nomear à autoria o proprietário ou

\footnotetext{
${ }^{201}$ Essa também é a posição de José Manoel de Arruda Alvim Netto, Código de processo civil comentado, p. 256; e de Sydney Sanches, Denunciação da lide no direito processual civil brasileiro, p. 92-93.

${ }^{202}$ A doutrina reconhece que o inciso II, do art. 70, possui características que se assemelham ao da nomeação à autoria, mas afasta-os, de maneira uniforme, em vista de os institutos possuírem finalidades diferentes. Nesse sentido: Athos Gusmão Carneiro, Intervenção de terceiros, n. 45.2, p. 117-118; Cândido Rangel Dinamarco, Intervenção de terceiros, n. 82, p. 161; Celso Agrícola Barbi, Comentários ao Código de Processo Civil, n. n. 404, p. 336-337; José Manoel de Arruda Alvim Netto, Código de processo civil comentado, p. 255-256; Sydney Sanches, Denunciação da lide no direito processual civil brasileiro, p. 8690.

${ }^{203}$ Existe esta confusão, de vez que o art. 99 do Código de Processo Civil de 1939 permitia a nomeação à autoria por aquele que possuísse "em nome de outrem a coisa demandada", o que foi desmembrado, corretamente, no Código de Processo Civil de 1973, ao permitir que o mero detentor continue tendo à sua disposição a nomeação à autoria (art. 62), cabendo ao possuidor direto denunciar a lide (art. 70, II).
} 
o possuidor (art. 62 do CPC), ao passo que, se for apenas possuidor direto, denunciará a lide ao proprietário ou ao possuidor indireto (art. 70, II, do CPC). Esse desdobramento das situações é proposital e foi previsto conscientemente pelo legislador, que visou separá-las e eliminar qualquer possível dúvida ou confusão.

A partir da interpretação literal do inciso II, do art. 70, do Código de Processo Civil, a denunciação só poderia ser realizada pelo possuidor direto, que é o réu, citado em nome próprio. Acrescente-se, outrossim, que a denunciação da lide, ao contrário da nomeação à autoria, não é modalidade de intervenção de terceiro adequada à correção do polo passivo da lide, bem como não guarda o caráter de ação de regresso.

Ocorre, todavia, que os demais dispositivos que tratam do instituto estabelecem, genericamente, poder ser feita a denunciação da lide tanto pelo autor como pelo réu. Assim, apesar de o inciso II referir-se unicamente ao réu, não existe razão para não se permitir a denunciação pelo autor, dado que, como assevera SYDNEY SANCHES, "as razões da denunciação deferida ao réu seriam as mesmas para que também ficasse permitida ao autor" ${ }^{204}$.

Ora, se o autor for possuidor direto, nada obsta a que denuncie a lide ao proprietário ou ao possuidor indireto, tal como é possível valer-se o requerente das demais hipóteses do art. 70. É o que ocorreria, por exemplo, se a posse direta do imóvel fosse exercida pelo locatário, que é demandado pelo verdadeiro proprietário do bem e que não o havia locado, podendo, eventualmente, denunciar a lide ao suposto locador (possuidor indireto).

\subsubsection{Da denunciação da lide para os demais casos de direito regressivo. $O$} inciso III, do art. 70, do texto processual estabelece a denunciação da lide "àquele que

\footnotetext{
${ }^{204}$ De maneira oportuna, ainda exemplifica, com propriedade, ao defender a denunciação, fundada no inciso II, pelo autor: "Imagine-se que um possuidor direto $(A)$ se sinta esbulhado por $B$, que não é o possuidor indireto, mas um estranho. $A$ propõe contra $B$ ação de reintegração na posse do bem. Mas $A$ pode ficar vencido na demanda porque a posse de $B$ tem melhor título. E, diante do caráter dúplice da ação possessória, $B$ é que há de ser amparado. Diante dessa possibilidade, nada haveria de impedir que $A$, na qualidade de autor da demanda possessória, logo ao início do processo, denunciasse a lide a $C$ (possuidor indireto), não só para auxiliar na defesa de seu alegado direito perante $B$, mas também para responder perante ele $(A)$ pela indenização devida com a eventual perda da posse direta face ao desfecho da causa" (Denunciação da lide no direito processual civil brasileiro, p. 93).
} 
estiver obrigado, pela lei ou pelo contrato, a indenizar, em ação regressiva, o prejuízo do que perder a demanda".

A previsão decorre da influência portuguesa, que estabelecia, no art. 325 do Código de Processo Civil de 1967, que "o réu que tenha ação de regresso contra terceiros para ser indenizado por ele dos prejuízos que lhe cause a perda de demanda, pode chamá-lo à autoria" ${ }^{205}$. O legislador brasileiro não restringe a denunciação apenas ao réu, de modo que, se a lei não distingue, o intérprete também não pode fazê-lo, até porque, caso o autor tenha direito de regresso contra alguém, não há razão plausível para afastar tal possibilidade.

Trata-se de previsão que amplia o instituto e não se limita às ações reais e ao caso de evicção. É a denunciação da lide fundada em garantia legal ou contratual, aplicando-se a todas as hipóteses de garantia própria (formal) e imprópria, assegurando, portanto, qualquer tipo de garantia, inclusive para ressarcimento de dano existente nas ações pessoais $^{206}$.

De maneira expressa, o dispositivo vincula o instituto às hipóteses em que for cabível a ação regressiva ao terceiro, obrigado a indenizar o vencido na ação principal por força de lei ou contrato. Sem nos preocuparmos em conceituar ação de regresso, por tratarse de tema de direito material, dado o legislador não se ter interessado em conceituá-lo e

${ }^{205}$ Cf. José Manoel de Arruda Alvim Netto, Código de processo civil comentado, p. 265-268. Celso Agrícola Barbi vai além e afirma que também há influência alemã, ao afirmar que "o item III é inspirado no art. 325 do Código português e no § 72, da Z.P.O. alemã” (Comentários ao Código de Processo Civil, n. 405, p. 338). Destaca-se, outrossim, que, na reforma de 1995 do Código de Processo Civil português, o âmbito do dispositivo foi modificado, fundindo num regime único a intervenção provocada e o chamamento à demanda, como ressalta Abílio Neto, ao anotar que "o incidente da intervenção principal provocada, na sua actual configuração normativa, abarca não só as hipóteses de intervenção principal provocada regulado no anterior art. 336. - 'pode também qualquer das partes chamar os interessados a que se reconhece o direito de intervir, seja como seu associado, seja como associado da parte contrária' dispunha o citado artigo -, como também as situações susceptíveis de integrar o pretérito chamamento à demanda, tipificadas no antigo art. $330 .^{\circ}$, e ainda quando, nos casos de cumulação subjectiva subsidiária, regulados no art. 31. ${ }^{\circ}$-B, o autor chame a intervir como réus os terceiros contra quem pretende formular pedido subsidiário. Em suma: este incidente engloba 'todos os casos em que a obrigação comporte pluralidade de devedores, ou quando existam garantes da obrigação a que a acção se reporta, tendo o réu interesse atendível em os chamar à demanda, quer para propiciar defesa conjunta, quer para acautelar o eventual direito de regresso ou sub-rogação que lhe possa assistir" (Código de Processo Civil anotado, nota 1 ao art. 325, p. 384).

${ }^{206}$ Milton Flaks diz que essa previsão legal "agasalha quaisquer outras hipóteses de direito regressivo (...) não contempladas pelos demais incisos ou pelo instituto do chamamento ao processo" (Denunciação da lide, p. 171). 
por não haver consenso sequer entre os doutrinadores empenhados em estabelecê-lo ${ }^{207}$, é certo que ele não se confunde com o direito decorrente das hipóteses dos incisos I e II, do art. 70, do Código de Processo Civil.

Além disso, o direito de regresso do denunciante em relação ao denunciado deve estar vinculado ao possível prejuízo que aquele tiver, no caso de sucumbir na ação principal. Por outro lado, o direito de indenização por evicção não constitui propriamente direito de regresso, mas de garantia decorrente da evicção. Também não é direito de regresso o do possuidor direto que o perde, em vista de o direito de indenização estar associado à posse direta.

Ressalva-se, ademais, não ser cabível a denunciação de lide para exercitar o direito de regresso decorrente da fiança, da co-fiança e das obrigações solidárias para as quais existe tratamento específico, na regra do art. 77 do Código de Processo Civil, devendo o direito de regresso ser buscado por meio do chamamento ao processo.

5.1.3.1. Do debate em torno da limitação ao art. 70, III, do CPC. Em vista da abrangência da previsão legal, que ampliou o cabimento da denunciação da lide permitindo que a parte chame terceiro qualquer que seja a natureza da garantia ou da obrigação - surgiu grande controvérsia, na doutrina e na jurisprudência, sobre o alcance que se pode dar à previsão do inciso III do art. 70 .

A polêmica gira em torno do equilíbrio que se busca obter no processo, dentre as diversas finalidades que com ele se pretenda. Assim, é preferível rápida prestação da tutela jurisdicional ou, seguindo a finalidade da denunciação da lide, resolver duas relações jurídicas numa só sentença? Sem dúvida alguma, seria preferível, na teoria, decidir tudo

\footnotetext{
${ }^{207}$ Sydney Sanches, após longa exposição sobre ação de regresso, diz que os doutrinadores italianos e brasileiros não chegaram a um consenso sobre o tema. Ao buscar uma definição, "na conceituação mais ampla possível envolveria: direito a indenização, direito a reembolso, direito decorrente de sub-rogação, direito à garantia (própria ou imprópria), direito à repetição de pagamento indevido, direito à indenização por locupletamento ou enriquecimento ilícito, etc. Em outra linha menos ampla, estariam envolvidos todos esses direitos, mas desde que o prejuízo experimentado (pelo titular do direito de regresso) tivesse resultado de uma derrota em juízo. Mais restritivamente se diria que o direito de regresso só envolve o direito de garantia propriamente dita" (Denunciação da lide no direito processual civil brasileiro, p. 117).
} 
conjuntamente, dado que se respeitaria o princípio da economia processual; na prática, entretanto, a denunciação poderia retardar o feito ${ }^{208}$.

Conferindo interpretação restritiva à denunciação, VICENTE GRECO FILHO repugna o "exercício abusivo do instituto". Admite apenas "a denunciação da lide nos casos de ação de garantia e não para os casos de simples ação de regresso". Sustenta, ainda, não ser possível "a intromissão de fundamento jurídico novo, ausente na demanda originária, que não seja responsabilidade direta decorrente da lei e do contrato", bem como que "uma das finalidades da denunciação é a de que o denunciado venha a coadjuvar na defesa do denunciante e não litigar com ele, argüindo fato estranho à lide secundária"209.

Tempera essa veemente restrição, no entanto, ao aceitar a denunciação no caso de seguro contratual, "mas desde que não haja, no contrato, cláusula de exclusão da garantia por risco extraordinário ou por culpa grave do segurado, porque, nestes casos, aduzir-se-ia, em detrimento do andamento do processo, questão nova estranha à demanda originária"210, de vez que se discutiria o risco e a culpa do segurado.

Essa também é a posição de SYDNEY SANCHES, que sustenta que o inciso III, do art. 70, do Código de Processo Civil "não pode ser interpretado com toda a extensão que seu texto pode, a um primeiro exame, sugerir". Defende "uma interpretação restritiva, que só permite a denunciação da lide para dedução de pretensão de garantia e de garantia própria. Não, assim, da chamada garantia imprópria". Apesar de reconhecer que a expressão literal do dispositivo é bastante ampla, diz que "não é dado interpretar a lei, dando-lhe um elastério tal que acabe por violar o princípio que ela pretendeu preservar: o da economia processual" 211 .

\footnotetext{
${ }^{208}$ Ovídio Araújo Batista da Silva pondera, a partir da "fundamental importância que o tempo desempenha na prestação jurisdicional", que o instituto "vem regulado em nosso Código - com o claro sentido de um chamamento em garantia - responde originariamente à mesma ideologia que permeia o sistema, desequilibrando-o em favor do demandado, ao obrigar o autor a suportar a inserção, em sua demanda, de uma nova controvérsia entre réu e um terceiro, com o consequente retardamento devido a complicações processuais daí derivadas" (Comentários ao Código de Processo Civil, p. 340).

${ }^{209} \mathrm{Diz}$, ainda, que "a figura só será admissível quando, por força da lei ou do contrato, o denunciado for obrigado a garantir o resultado da demanda, ou seja, a perda da primeira ação, automaticamente, gera a responsabilidade do garante" (Direito processual civil brasileiro, p. 143).

${ }^{210}$ Direito processual civil brasileiro, p. 143-144. Ocorre, todavia, que essa possibilidade aventada se contradiz com os fundamentos que amparam a interpretação restritiva.

${ }^{211}$ Denunciação da lide no direito processual civil brasileiro, p. 120-123.
} 
Por esse raciocínio, prestigiam-se, fundamentalmente, os princípios da economia e da rápida entrega da prestação jurisdicional, não se admitindo a introdução de fato novo, estranho à relação jurídica a ser dirimida na ação principal. Na realidade, a finalidade do instituto é justamente a de resolver, de maneira célere, duas relações jurídicas, sem que se retarde a prestação da tutela pleiteada pelo autor; ele não pode ser compelido, por ter sido proferida uma única sentença, a aguardar a produção de prova das questões fáticas controvertidas da ação secundária, enquanto a ação principal já está em condições de ser decidida.

Isso posto, os fundamentos invocados não se prestam, a nosso ver, para afastar a aplicação da denunciação da lide.

Por primeiro, o dispositivo trata, expressamente, de ação regressiva, não sendo possível afastar sua interpretação literal e permitir a denunciação apenas para os casos de ação de garantia. Não se identifica, ademais, no ordenamento brasileiro, ao contrário do que sucede no direito positivo italiano, qualquer distinção entre a garantia própria e a imprópria $^{212}$.

Além disso, revela-se prematuro, no mínimo, impedir a denunciação por haver fundamento ou fato novo, dado que, antes da citação do denunciado, não se sabe qual postura ele adotará: poderá aceitar a denunciação, ficar revel, reconhecer juridicamente o pedido e confessar, entre outras possibilidades, evidenciando ser descabido o indeferimento imediato da denunciação, instrumento que garante grande efetividade ao processo. Poderá eventualmente o denunciado não introduzir qualquer fato novo e simplesmente auxiliar a defesa do denunciante, com o que se comprovaria a total incongruência dessa receosa interpretação restritiva.

Ainda, porém, que o denunciado introduza fato novo, que seja relevante e que se torne controvertido, a prova da lide secundária pode eventualmente não representar retardamento da prestação da tutela jurisdicional. Se o denunciado alegar fato extintivo do

\footnotetext{
${ }^{212}$ Cândido Rangel Dinamarco explica que garantia própria existe apenas da parte de quem haja transferido um bem (garantia formal ou real) ou daquele que está obrigado a pagar débito alheio (garantia pessoal ou simples), sendo que o sistema italiano admite somente em relação a esta a chiamata in garanzia. Em casos de garantia imprópria, a parte deve provocar o chamado intervento coatto (Intervenção de terceiros, n. 105, p. 197).
} 
direito do denunciante - como, por exemplo, a seguradora afirmar que o segurado está inadimplente e provar que cobrou o pagamento das parcelas não pagas - a dilação probatória será nenhuma ou, quando muito, mínima, ensejando simples produção de prova documental a ser diretamente trazida pelas próprias partes, enquanto que o benefício da denunciação poderá ser decisivo para a efetividade da tutela jurisdicional.

Não é possível ignorar, ademais, que, muitas vezes, há vários fatos relevantes e controvertidos a serem objeto de prova na ação principal, a ser realizada por diversos meios legais, de maneira que a prova dos fatos novos introduzidos, na ação de regresso, pode ser colhida conjuntamente, esforçando-se a parte interessada em demonstrá-los, a fim de não arcar com o ônus da falta de prova, nos termos do art. 333 do Código de Processo Civil.

A denunciação da lide possibilita a cumulação subjetiva e objetiva, o que não retarda, necessariamente, a marcha do processo. Como a relação jurídica envolvendo autor e réu é distinta daquele entre denunciante e denunciado, é natural que quase sempre exista um fundamento jurídico novo. Não admitir a denunciação, em decorrência do problema do fundamento novo, é negar a própria essência do instituto, que não protege o denunciante em detrimento da parte contrária da ação principal, mas o próprio sistema.

Pior remédio se mostra ao permitir-se a introdução de fato novo apenas no caso de seguro contratual, mas não aplicar a regra a todas as demais hipóteses. Inexiste diferença prévia quanto à natureza dos fatos novos a serem introduzidos que permita, genericamente, realizar essa discriminação. Na lide secundária, a seguradora pode discutir sua responsabilidade contratual, introduzindo fato novo, que não demandará a produção de menos prova ou não consumirá menos tempo do que em outras situações em que o réu denuncia a lide para terceiros. Não há fundamento legal, muito menos coerência, para ignorar os princípios da economia e celeridade processuais quando se trata de seguro contratual, permitindo a introdução de fato novo, notadamente não se fazendo o mesmo nas demais hipóteses de ação de regresso. Esse raciocínio é ilógico, não sendo possível tratar distintamente as situações, a não ser se permitindo um favorecimento à atividade de seguro, sem respaldo legal e constitucional. 
Para prevalecer o fundamento da interpretação restritiva, também não deveria ser permitido que o réu alegasse fatos impeditivos, modificativos ou extintivos do direito do autor, em vista de eles possivelmente retardarem a prestação da tutela jurisdicional pleiteada pelo demandante, por força da necessidade de se produzirem provas. Se assim não fosse, incabível seria a reconvenção, pela mesma perspectiva, dado ser desarrazoado o réu trazer novos fatos e pedidos, que também deverão ser resolvidos por meio de uma única instrução processual e sentença. Não há razão para a discriminação do instituto, ao qual deve ser conferido tratamento igual ao das hipóteses ora apontadas.

Mesmo com fatos novos e tudo quanto eles reclamam, a denunciação não contrariará propriamente o princípio da economia processual, mas justamente o contrário, dado que se resolverão duas demandas, num único processo, o que representa um proveito bem maior. Com propriedade, ALEXANDRE FREITAS CÂMARA, ao criticar a teoria restritiva, assevera que por meio de denunciação da lide se alcançará, "de forma muito mais efetiva, o escopo pacificador do processo". Não é aceitável a crítica de que o instituto torna mais moroso o processo e ofende o princípio da celeridade processual, de vez que "não se pode aceitar mais a visão do processo civil do autor, que por tanto tempo prevaleceu. O que se busca agora é um processo civil de resultados, e que o processo é instrumento de realização dos escopos (sociais, políticos e jurídicos) da jurisdição"213.

Com efeito, não há como prestigiar a parte contrária do denunciante, que, geralmente, é o autor, até porque o juiz deve assegurar às partes igualdade de tratamento (art. 125, I, do CPC). É certo, ademais, que compete ao juiz, velando pela rápida solução do litígio, reprimir abusos e qualquer ato contrário à dignidade da justiça (art. 125, III, do CPC) e indeferir as diligências inúteis ou meramente protelatórias (art. 130 do CPC), do que poderá se valer o juiz, se ficar claro o intuito procrastinador do denunciante. Não há como ignorar que, cada vez mais, o sistema preocupa-se em conferir efetividade ao processo, de modo a valorizar mecanismo para evitar o retardamento decorrente da denunciação da lide feita pelo réu: pode o juiz, por exemplo, até antecipar, total ou parcialmente, os efeitos da tutela antecipada pretendida, desde que o caso se enquadre numa das hipóteses legais (art. 273 do CPC).

${ }^{213}$ Intervenção forçada de terceiros e responsabilidade civil do Estado, p. 19. 
Ao tratar da admissibilidade da denunciação da lide, CÂNDIDO RANGEL DINAMARCO discorda da interpretação restritiva, ao dizer que ela não tem apoio em qualquer regra de direito positivo brasileiro e "remonta notoriamente a pensamentos da doutrina italiana", que distinguem casos de intervento coatto de casos de chiamata in garanzia $^{214}$.

Na mesma linha, AROLDO PLÍNIO GONÇALVES destaca, ao também criticar a interpretação restritiva, que o sistema brasileiro não é igual ao italiano, bem como que o legislador pátrio não o restringiu, mas explicitamente o ampliou, o que torna a denunciação da lide admissível "em qualquer situação em que alguém tenha ação de regresso em face de outrem, isto é, tenha ação para recuperar do denunciado aquilo que tiver que pagar na demanda originária". 215

Negando a interpretação restritiva, mas com ressalvas a admitir a plena ampliação do objeto litigioso decorrente da denunciação, DANIEL USTÁRROZ conclui não ser "a mera introdução de fato novo que impede o manuseio da denunciação, mas sim os efeitos concretos que esse comportamento acarretará ao processado. Novamente, ao analisar seu cabimento, o órgão judicial deverá motivar seu provimento à luz dos princípios maiores da ordem processual: segurança e efetividade, preservando, na medida das contingências do caso, seu núcleo essencial, para garantir a isonomia das partes"216.

Nesse mesmo sentido, ATHOS GUSMÂO CARNEIRO também adota uma posição intermediária, ao reconhecer “que o ‘fundamento' da denunciação nunca será o mesmo 'fundamento' da ação" e sustentar ser necessário um criterioso exame do

${ }^{214}$ Cândido Rangel Dinamarco afirma que interpretação restritiva apoia-se "em conceitos e distinções vigentes no direito italiano, que no Brasil inexistem - especialmente na distinção entre garantia própria e garantia imprópria. Na Itália, em caso de garantia própria, a parte tem a faculdade de fazer a chiamata in garanzia (equivalente a litisdenunciação brasileira) e, quando a garantia for imprópria, ela dispõe do intervento coatto, que produz efeitos análogos ao daquela. No Brasil, em que inexiste essa segunda modalidade, a distinção proposta deixaria a parte sem qualquer possibilidade de trazer o terceiro ao processo. O resultado, sumamente injusto, consistiria em privar a parte dos benefícios da litisdenunciação, a saber: ela necessitaria de propor depois a sua demanda pelo ressarcimento, com o risco de voltar a sucumbir em face do garante" (Instituições de Direito Processual Civil brasileiro, v. II, p. 404). Acrescenta, ademais, que o art. 70, III, do texto processual ficaria "praticamente sem vigência", justamente quando o legislador pretendeu ampliar as hipóteses, "porque o único caso realmente manifesto de responsabilidade direta do terceiro, no qual a sucumbência do garantido gera a automática responsabilidade do garante sem a intromissão de fundamento jurídico novo', seria mesmo o da evicção, já contemplada no inc. I. Em todos os demais, sempre algum fundamento jurídico novo, mais ou menos relevante ou complexo, acaba por ser introduzido no processo" (Intervenção de terceiros, p. 195-205).

${ }_{215}$ Da denunciação da lide, p. 244-245.

${ }^{216}$ A intervenção de terceiros no processo civil brasileiro, p. 99. 
cabimento da denunciação da lide no caso concreto. Acrescenta que "impende ao juiz ponderar qual dos interesses merece prevalecer: o do denunciante, em que a ação de regresso seja simultaneamente processada e julgada, ou o interesse do autor no sentido de que o andamento de sua demanda não seja obstaculizado pela propositura de uma nova ação pelo réu" 217 .

Por outro enfoque, OVÍDIO ARAÚJO BATISTA DA SILVA critica as interpretações restritiva e a francamente extensiva, ao sustentar "que o ponto adequado deve ficar a meio caminho entre os extremos, considerando que a denunciação, com base no art. 70, III, deve limitar-se aos casos de verdadeiro direito de regresso", e concluir que, "para haver verdadeira ação de regresso, é necessário que o autor tenha satisfeito a obrigação, prestando ao terceiro em virtude de lei ou de contrato, sub-rogando-se em seu lugar, como demandado" 218 .

Consideramos que a denunciação da lide deve ser admitida, presentes os requisitos legais do inciso III, do art. 70, do Código de Processo Civil, se não possuir caráter meramente protelatório ou for manifestamente impertinente. Não há como a limitar, em vista de não se saber e não ser possível presumir, antes da citação, qual conduta processual o denunciado adotará, além de ser a introdução de nova matéria fática ou de novo fundamento jurídico decorrência natural do instituto por representar uma nova demanda. É certo, ademais, que o juiz tem o dever de assegurar não só igualdade de tratamento às partes, mas também mecanismos para reprimir abusos, indeferir provas que não sejam úteis e antecipar os efeitos da tutela pretendida, sem privar o denunciante de auxílio do denunciado, que, de maneira decisiva, poderá contribuir na sua defesa.

A teoria restritiva faz vistas grossas para uma das finalidades da denunciação da lide, que é a possibilidade de o denunciado auxiliar a defesa do denunciante. A questão não pode ser enfrentada simplesmente em decorrência do que será objeto de controvérsia na lide secundária, dado que, se assim for, estar-se-á afastando o instituto de sua característica

\footnotetext{
${ }^{217}$ Intervenção de terceiros, p. 122-123.

${ }^{218} \mathrm{O}$ autor ressalta, ademais, que "mesmo quando o Código vede a intervenção de terceiros, na forma e com as conseqüências nele estabelecidas, é cabível a denúncia simples do litígio, com a sentido de simples notificação, a fim de que o terceiro fique exposto ao efeito da intervenção (art. 55), que se limitará a defesa na demanda de regresso que a parte sucumbente vier a propor-lhe em processo independente" (Comentários ao Código de Processo Civil, p. 343).
} 
de origem associada ao direito germânico primitivo e considerando-o apenas como voltado ao reembolso, de origem romana, o que, todavia, não se ajusta ao sistema pátrio vigente.

O processo não pode transformar-se em instrumento para simplesmente atender às pretensões do autor a qualquer custo, não sendo razoável conferir maiores direitos a ele em detrimento do réu, por força de ter tomado a iniciativa de buscar o Judiciário. Deve haver equilíbrio e, se for necessário, ampliar-se o debate e a produção de provas, sem que isso represente abuso, a não ser que a parte contrária ao denunciante convença e demonstre que a denunciação retardará, demasiadamente, a prestação da tutela jurisdicional e comprometerá a efetividade do processo. Acrescente-se, ainda, que seria extremamente desigual restringir a aplicação do instituto e impedir a facultatividade da denunciação. Não é justo e sequer técnico, ao menos, impor o ajuizamento de ação autônoma de regresso ao denunciante, suportando este os ônus processuais e o risco de novamente sucumbir, desta vez em relação ao terceiro que teria a obrigação legal ou contratual de indenizá-lo do prejuízo que sofrer com a perda da ação.

5.2. Da faculdade da denunciação pelo autor. Na denunciação da lide feita pelo autor, há uma cumulação subjetiva eventual de pedidos, de modo que o demandante formula pedido em face do réu que, se for julgado procedente, torna prejudicado o realizado em face do denunciado, em razão de este ser subsidiário. Se o pedido do autor feito ao réu não for acolhido, subsiste a denunciação da lide, revelando-se, claramente, o interesse processual do demandante, até porque se trata de um cúmulo sucessivo, já que são postuladas duas coisas; a obtenção da primeira, porém, já satisfaz o interesse do requerente, havendo, pois, um elo de prejudicialidade entre ambas.

Ao denunciar a lide, o autor revela preferência quanto ao pedido feito em relação ao réu, mas, a título subsidiário, cumula pedido, na mesma iniciativa processual, em vista do denunciado, ampliando, em tese, a potencialidade de sua pretensão de direito material ser acolhida. É inegável ter a silhueta da denunciação da lide, quando realizada pelo autor, particularidades inadequadas à restrição que alguns emprestam à sua ocorrência no polo passivo; é, sem dúvida, uma demanda cumulada de forma eventual para que o julgador 
examine o pedido contra o denunciado, se o que se pediu em relação ao réu não for procedente $^{219}$.

A possibilidade de o autor denunciar a lide, fazendo-o na petição inicial, não viola propriamente o princípio da razoável duração do processo, até mesmo porque é o próprio demandante quem postula a intervenção de terceiro, sendo "o maior interessado no andamento rápido do feito" 220 . A introdução de fatos e fundamentos jurídicos novos, em decorrência da lide secundária, também não restringe a utilização do instituto pelo demandante, até porque ele o faz no momento do nascedouro da demanda, de modo que o processo já se originará ampliado e com esses traços, sem riscos de modificação no seu desenvolvimento.

Há, pois, um cúmulo originário, enquanto que a denunciação pelo réu constitui um cúmulo ulterior. Além disso, contribui para a economia do processo e está rigorosamente afinado ao disposto no art. 289 do Código de Processo Civil, evitando-se, no caso de a ação ser julgada improcedente, que o autor tenha que demandar novamente, colocando, então, aquele que seria denunciado no polo passivo.

A questão é bem abordada por CÂNDIDO RANGEL DINAMARCO, ao afirmar que o cúmulo eventual é a "construção dada ao instituto da denunciação da lide, na feição que assume quando feita pelo autor; resolve-se ela numa demanda relativa ao réu 'principal' e outra, subsidiária, de condenação do garante no caso de não vingar a primeira pretensão (cúmulo subjetivo de dois réus perante o mesmo autor; cúmulo objetivo de demandas, uma envolvendo cada um deles)" ${ }^{\text {,21 }}$. Em vista do fenômeno da cumulação eventual subjetiva, existe, pois, a possibilidade de se intentar demanda cumulada, mas dirigida a pessoas diferentes.

\footnotetext{
${ }^{219}$ Nesse sentido, Clito Fornaciari Júnior defende que deve haver leitura diversa entre a denunciação da lide feita pelo autor e a realizada pelo réu, concluindo que "não se pode cogitar de confinar os fundamentos da denunciação da lide, ou da demanda posta como subsidiária, aos mesmos fundamentos da ação contra o réu intentada pelo autor e denunciante", ao criticar acórdão do extinto Segundo Tribunal de Alçada Civil de São Paulo (processo n. 672.360-00/2, Rel. LUIZ DE LORENZI, J. 14/02/2001), que aplicou a tese restritiva e indeferiu a denunciação da lide feita pelo autor, de vez que considerou não ser "possível o pedido cumulado eventual nos moldes do art. 289 do CPC, sob as vestes da denunciação feita pelo autor" ("Limites da denunciação da lide pelo autor", in Processo civil: verso e reverso, p. 35).

${ }^{220}$ Cf. Cássio Scarpinella Bueno, Partes e terceiros no processo civil brasileiro, p. 227.

${ }^{221}$ Litisconsórcio, n. 56, p. 311.
} 
Diante das peculiaridades da denunciação feita pelo autor, as pretensões e as causas de pedir são diferentes, porém devem ser compatíveis entre si, tal como sucede na cumulação de vários pedidos contra o mesmo réu (art. 292, § 1º, do CPC), e devem estar ancoradas em alicerce de fato comum.

A propósito, oportunas são as considerações de JOSÉ ROGÉRIO CRUZ E TUCCI, ao afirmar que "a legislação processual dispensa, nesse tipo de cúmulo, qualquer compatibilidade ou nexo substancial entre os pedidos", devendo, porém, estar fundados na mesma gênese fático-jurídica ${ }^{222}$. Acrescenta, ao se voltar ao instituto da denunciação, que a “causa petendi, narrada no processo em que o denunciante é parte, deverá guardar conexidade com a demanda denominada secundária, viabilizando, destarte, a denunciação nas hipóteses previstas no art. 70 do Código de Processo Civil. A intensidade da conexão, todavia, dependerá das circunstâncias de cada caso concreto, sendo maior na situação do inc. I do art. 70, e muito mais tênue na do inc. III, quando, por exemplo, a denunciação da lide é fundada no direito de regresso decorrente do contrato de seguro"223. De qualquer modo, ainda que possa ser mais tênue a intensidade, existe a conexão, viabilizando a aplicação do instituto, pois o sistema não estabelece qual deveria ser a força necessária.

Assim, a tese ampliativa deve prevalecer, com muito mais razão, quando se trata de denunciação da lide feita pelo autor, não havendo margem para restringir a aplicação do instituto, invocando-se a interpretação restritiva ${ }^{224}$. Na realidade, cuida-se de uma faculdade conferida ao autor, fundado na possibilidade de cumulação subjetiva eventual dos pedidos contra pessoas distintas, que não é vedada, mas, ao contrário, prestigiada pelo sistema.

\footnotetext{
${ }^{222}$ Causa de pedir e pedido no processo civil:(questões polêmicas), p. 285.

${ }^{223}$ A causa petendi no processo civil, p. 217-218.

${ }^{224}$ Abílio Neto, ao anotar sobre o chamamento à autoria, tal como o instituto é denominado no Código de Processo Civil português, destaca a preponderância que deve ser conferida à interpretação ampliativa, reportando-se à seguinte decisão: "I - A acção de regresso a que se refere o n. 1 do art. $325^{\circ}$ do Cód. de Proc. Civil deve reportar-se a uma relação conexa com a relação jurídica controvertida, podendo basear-se tanto em lei expressa ou contrato, como em qualquer outro acto, que dê lugar à responsabilidade civil. II Tal conexão não exige uma absoluta subordinação, à relação principal, da relação jurídica estabelecida entre o réu e o chamado; basta uma relativa dependência, resultante de a pretensão do réu contra o chamado se filiar no facto de este o ter exposto a uma demanda e à perda dela. III - O chamamento à autoria só se justifica quando, em virtude dessa relação conexa, o chamado deva responder pelo dano resultante da sucumbência do réu, pois é esta afinal que se lhe virá impor, como caso julgado através daquele meio processual (Ac. STJ, de 28.6.1979, BMJ, 288 -360) (Código de Processo Civil anotado, nota 17.I, ao art. 330, p. 392-393).
} 


\subsection{Da denunciação da lide pelo Estado ao agente público responsável pelo}

dano. Hipótese de cabimento, em tese, de denunciação da lide, por força da aplicação do inciso III, do art. 70, do texto processual é a do Estado ao servidor público, por comportamento doloso ou culposo deste.

$\mathrm{O}$ art. $37, \S 6^{\circ}$, da Constituição Federal dispõe que "as pessoas jurídicas de direito público e as de direito privado prestadoras de serviços públicos responderão pelos danos que seus agentes, nessa qualidade, causarem a terceiros, assegurando o direito de regresso contra o responsável nos casos de dolo ou culpa"225.

Em ação indenizatória promovida em face do Estado, o autor deve provar o fato danoso e o nexo de causalidade, não sendo necessário demonstrar o dolo ou a culpa do funcionário - dado que a pretensão está fundada na responsabilidade objetiva - bastando a prova da relação causal entre o comportamento e o dano. Por sua vez, o Estado pode defender-se e tem, ainda, a faculdade de denunciar a lide ao servidor causador do dano; além disso, por a responsabilidade deste servidor ser subjetiva, o dolo ou a culpa constitui, na lide secundária, fato relevante. Surge, então, questão tormentosa sobre possível exclusão da responsabilidade subjetiva do agente público causador do dano, diante da responsabilidade objetiva do Estado.

A partir do disposto no art. $37, \S 6^{\circ}$, da Constituição Federal, que assegura o direito de regresso do Estado, é possível concluir que a responsabilidade objetiva não exclui a subjetiva, podendo o regresso ser buscado na mesma demanda ou em processo autônomo, já que não se trata de hipótese de denunciação da lide obrigatória. Em vista disso, consideramos possível - em que pese a referida previsão legal libertar-se da teoria subjetiva da culpa, o que facilitaria, em tese, o direito de a vítima obter indenização - ela ajuizar ação de reparação em face do agente público causador do dano, dado que o art. 927 do Código Civil estabelece que aquele que causar dano a outrem, por ato ilícito, fica obrigado a repará-lo. A responsabilidade civil subjetiva não é, pois, excluída pela regra constitucional. Como destaca ALEXANDRE FREITAS CÂMARA, “a responsabilidade

${ }^{225}$ Hely Lopes Meirelles explica que "o dispositivo constitucional só abrange a atuação funcional dos servidores públicos, e não os atos de terceiros e os fatos da Natureza", concluindo que "para situações diversas, fundamentos diversos" (Direito administrativo brasileiro, p. 591). 
civil objetiva do Estado foi uma criação do ordenamento jurídico destinado a ampliar as garantias da vítima, e não reduzi-las", de modo que "havendo dispositivo legal que afirma que aquele que causar dano por culpa sua tem o dever de indenizar a vítima, não se pode afastar a responsabilidade civil do agente causador do dano" 226.

Assim, a responsabilidade objetiva do Estado amplia a proteção da vítima, mas não há como restringir que ela só possa ajuizar ação em face das pessoas jurídicas de direito público e das de direito privado prestadoras de serviços públicos. Na realidade, ela pode mover ação diretamente em face do agente público ou do Estado, bem como em face de $\operatorname{ambos}^{227}$, sendo que nas situações em que envolver o funcionário, deverá ser demonstrada sua culpa ou seu dolo, por a pretensão envolver a responsabilidade subjetiva.

A par dessas considerações, ressalta-se haver, no caso de a ação de indenização ser ajuizada apenas em face das pessoas jurídicas de direito público e das de direito privado prestadoras de serviços públicos, divergência quanto ao cabimento, na prática, da denunciação da lide pelo Estado ao agente público.

Antes de qualquer consideração, importante destacar que o art. 197, § $2^{\circ}$, da Lei 1.711/52 (Estatuto dos Funcionários Públicos Civis da União) estabelecia que em se tratando "de dano causado a terceiro, responderá o funcionário perante a Fazenda, em ação regressiva, proposta depois de transitar em julgado a decisão de última instância que houver condenado a Fazenda a indenizar o terceiro prejudicado". Referida disposição foi revogada pela Lei 8.112/90, mas, enquanto estava em vigor, o Estado não podia valer-se da denunciação da lide como ação de garantia, mas apenas como simples denúncia do litígio $^{228}$. A previsão estava associada ao direito romano e ficou em desarmonia com o

\footnotetext{
${ }^{226}$ Aponta, ainda, para vários inconvenientes práticos de cobrar indenização do Estado, o que não ocorre se a ação é ajuizada apenas em face do causador do dano, que não terá diversas prerrogativas processuais: há "pessoas jurídicas de Direito Público paupérrimas", "que podem não ter qualquer condição de pagar uma indenização, ainda que pequeno seu valor"; "quem cobra do Estado tem de se submeter a um processo longo, em que não se consegue tutela antecipada"; e "a sentença fica sujeita ao duplo grau de jurisdição obrigatório, não cabe execução provisória, não se pode efetuar uma penhora, realizando-se o pagamento por precatório" (Intervenção forçada de terceiros e responsabilidade civil do Estado, p. 12).

${ }^{227}$ Nesse sentido, o Superior Tribunal de Justiça tem decidido: "Inexiste a vedação legal ao litisconsórcio entre o ente estatal e os agente públicos causadores do dano em ação de indenização por responsabilidade civil do Estado" (REsp 997.761/MG, Rel. Min. CASTRO MEIRA, 2a Turma, J 10/06/2008, DJe 23/06/2008)".

${ }^{228}$ Ainda na vigência da referida lei, Milton Flaks explicou que um comando administrativo interno veda a propositura de ação regressiva, esclarecendo, com propriedade, que "havendo indícios de que o servidor se houve com culpa, o Estado denunciará a lide apenas para vinculá-lo às questões comuns e conexas com as de 
Código de Processo Civil de 1973, quando este passou a vigorar, sendo só posteriormente revogada de modo expresso.

Diante da revogação dessa previsão legal e da inexistência de vedação, reforça-se a possibilidade de o Estado denunciar a lide ao funcionário, fazendo-o não apenas para vinculá-lo às questões comuns e conexas, mas também para enfrentar, no mesmo processo, a culpa dele. Não fosse esse o espírito do legislador, certamente a regra teria sido mantida, evidenciando-se ser inadmissível restringir o cabimento do instituto da denunciação da lide, podendo a responsabilidade do servidor ser enfrentada desde logo e não apenas após o trânsito em julgado da sentença que houver condenado a Fazenda.

Apesar disso, tecnicamente, a controvérsia acirra-se relativamente às características do instituto da denunciação da lide, à distinção da natureza das responsabilidades, bem como à aplicação das teorias restritiva e ampliativa, analisada no capítulo sobre o debate em torno da limitação do art. 70, III, do Código de Processo Civil.

Diante dos contornos da denunciação, não há dúvida de que ela é cabível. Além de essa intervenção forçada constituir ação de regresso, é certo que o agente público poderá auxiliar o Estado em sua defesa, mostrando como se deu o fato, alegando não ter havido dano ou, ainda, que se cuida de hipótese de culpa exclusiva do autor ou culpa concorrente. Sua proximidade com os fatos possibilitar-lhe-á deduzir essas alegações com maior rigor e precisão. Tal hipótese, ainda que não eximisse por completo a responsabilidade estatal, poderá repercutir sobre o valor da indenização. Essa assistência poderá, desta forma, ser importante para o desfecho da demanda, até porque o funcionário terá opção de contribuir para demonstrar se está caracterizado o nexo causal entre a atuação do Estado e o dano ocorrido.

Assim sendo, a natureza das responsabilidades é distinta, dado que a do Estado é objetiva, não importando se o agente atuou culposa ou dolosamente, mas apenas que a sua qualidade de agente público foi determinante para a conduta lesiva. O Estado tem a responsabilidade de reparar os danos, pelo simples fato de eles terem ocorrido. É o que se

uma eventual ação regressiva autônoma: existência ou não de culpa da vítima; montante da indenização. Vencido na demanda originária, poderá propor ação de regresso, na qual as questões anteriormente decididas constituirão prejudiciais de mérito. Assim, o debate ficará circunscrito à matéria que não foi objeto de exame ou decisão: a culpa do servidor" (Denunciação da lide, p. 177). 
denomina de teoria do risco administrativo, que, segundo JOSÉ DE AGUIAR DIAS, é a fórmula doutrinária a que tende a responsabilidade civil do Estado, como meio de dar satisfação às necessidades gerais da coletividade e evitar a violação de direitos individuais $^{229}$.

Diferentemente, a responsabilidade do funcionário, causador do dano, é subjetiva, o que introduz fato novo - não entendido como objeto da ação principal, mas associado à existência do direito de regresso - e amplia a produção de prova, de vez que o reconhecimento do direito de regresso da pessoa jurídica de direito público depende da demonstração de culpa ou dolo do funcionário.

Antes de enfrentar a questão das diferenças entre responsabilidade objetiva e subjetiva e independentemente de se considerar aplicável a concepção restritiva ou ampliativa a essa situação, pondere-se que o Estado resistirá à pretensão do autor, apresentando contestação. A circunstância de a sua responsabilidade ser objetiva não se traduz, por lógico, em conferir, automaticamente, razão ao autor, dado que este deverá desincumbir-se do ônus de demonstrar, ao menos, o dano e o nexo de causalidade.

Assim, o Estado, ao impugnar os fatos constitutivos do direito do autor, pode alegar que não houve dano, que o ato não produziu lesão ou que sua atuação não contribuiu para o prejuízo ${ }^{230}$. Se assim for, haverá, diante da controvérsia, necessidade de se produzir prova desses fatos, de modo a não ser possível afastar, genericamente, o cabimento da denunciação da lide, ainda que se prestigie a teoria restritiva.

$\mathrm{Na}$ realidade, o fato novo, introduzido pela denunciação da lide, embora tenha potencial para ampliar o objeto de prova associada ao dolo e à culpa do agente público, não retardará isoladamente a prestação da tutela jurisdicional. Ora, se o Estado impugna a existência do dano ou alega não haver nexo causal, o autor terá o ônus de provar esses fatos (art. 333, I, do CPC), até porque, via de regra, os fatos negativos não são suscetíveis de serem demonstrados. Caso o Estado alegue que a culpa pelo dano é exclusiva do autor,

\footnotetext{
${ }^{229}$ Da responsabilidade civil, p. 824/829.

${ }^{230}$ Hely Lopes Meirelles pondera que "para eximir-se dessa obrigação incumbirá a Fazenda Pública comprovar que a vítima concorreu com culpa ou dolo para o evento danoso. Enquanto não evidenciar a culpabilidade da vítima, subsiste a responsabilidade objetiva da Administração. Se total a culpa da vítima, fica excluída a responsabilidade da Fazenda Pública; se parcial, reparte-se o quantum da indenização" (Direito administrativo brasileiro, p. 593).
} 
este terá que provar que não concorreu para o dano, de modo que os fatos a serem demonstrados, na ação principal e na lide secundária, estão intimamente associados. Além disso, tais fatos serão objeto de prova a ser produzida, muito possivelmente, pelos mesmos meios, para revelar a incongruência de não se permitir a intervenção de terceiro e de se rotular, genericamente, o comprometimento da duração razoável do processo em consequência do fato novo introduzido.

Assim, consideramos não ser possível indeferir a denunciação da lide do Estado ao agente público, dado que os fatos a serem objeto de prova, na ação principal e também na ação de regresso, podem estar extremamente vinculados e podem ser demonstrados, muito provavelmente, pelos mesmos meios de prova.

Pondere-se, ademais, que, diante de comportamento omissivo do Poder Público, a responsabilidade do Estado é subjetiva, de vez que o dano não foi causado pelo funcionário público, mas em decorrência da omissão dele: se o servidor público tivesse agido, poderia ter evitado que o dano fosse causado ${ }^{231}$. Nesse caso, será necessário demonstrar o ato culposo ou doloso do agente público e assim, com maior razão, cabe a denunciação da $\operatorname{lide}^{232}$.

Diante dessas perspectivas diferentes da natureza da responsabilidade, aqueles que se filiam à concepção restritiva consideram não serem elas hipóteses para permitir a intervenção de terceiro. Sustentam que o instituto não pode ser aplicado, por tratar-se de garantia imprópria e por não ser razoável perquirir sobre culpa ou dolo do agente público, de vez que a responsabilidade estatal depende apenas da prova da existência do nexo causal entre a atuação do Estado e o dano ocorrido; assim sendo, seria penoso impor à vítima que suportasse o desenrolar da lide secundária, em vista de ambos os conflitos

\footnotetext{
${ }^{231}$ A responsabilidade objetiva do Estado aplica-se aos atos comissivos, porém ela será subjetiva quanto aos atos omissivos do poder público. Nesse sentido: "Constitucional. Administrativo. Civil. Dano moral. Responsabilidade civil das pessoas jurídicas de direito público e das pessoas jurídicas de direito privado prestadoras de serviço público. Ato omissivo do poder público: morte de presidiário por outro presidiário: responsabilidade subjetiva: culpa publicizada: faute de service. C.F., art. 37, § 6”" (STF, RE 179147, Rel. Min. CARLOS VELLOSO, $2^{\text {a }}$ Turma, J 12/12/1997).

${ }^{232}$ Leonardo José Carneiro da Cunha sustenta o cabimento da denunciação apenas na hipótese de responsabilidade subjetiva ao Estado, pois "não haveria o acréscimo de qualquer elemento novo à demanda". Exemplifica, ainda, ao reportar-se à ação "indenizatória, fundada numa alegada tortura cometida por agentes policiais. Nesse caso, haverá, desde o início, a necessidade de comprovar-se a tortura, ato culposo ou doloso que irá fundamentar, da mesma forma, a denunciação de lide, cuja instauração não irá gerar a agregação de elemento novo no processo, nem desencadear a necessidade de uma instrução que, inicialmente, seria desnecessária" (Breves notas sobre a denunciação da lide ao agente público pela Fazenda Pública, p. 341).
} 
deverem ser decididos pela mesma sentença, até chegarem à decisão que diz respeito aos seus interesses.

Sobre o assunto, nesse sentido, CELSO ANTÔNIO BANDEIRA DE MELLO sustenta o descabimento da denunciação da lide nas hipóteses de haver responsabilidade do Estado, por considerar que mesclar "o tema de uma responsabilidade objetiva - a do Estado - com elementos peculiares à responsabilidade subjetiva - a do funcionário" redundaria em prejuízos para o autor, de vez que retardaria o reconhecimento do seu direito, dependente da solução do conflito de interesses entre o Estado e o funcionário ${ }^{233}$.

Ocorre, todavia, que a vítima não terá que discutir sobre a culpa, muito menos prová-la, pois a questão será objeto apenas da lide secundária, de vez que a ação de regresso está fundada justamente no dano causado pelo agente público, por ato ou omissão administrativa no exercício de suas atribuições, ou a pretexto de exercê-la. Dessa maneira, o autor, vítima do dano, não precisará discutir culpa para o seu direito a indenização ser reconhecido; logicamente, no entanto, terá o ônus de acompanhar e participar dessa atividade probatória.

Ao também considerar incabível a intervenção de terceiro no mesmo processo, HELY LOPES MEIRELLES condiciona a ação regressiva a dois requisitos: "que a Administração já tenha sido condenada a indenizar a vítima do dano sofrido" e "que se comprove a culpa do funcionário no evento danoso" ${ }^{, 234}$. No entanto, antes de se ter denunciado a lide, evidentemente que o Estado ainda não foi condenado, dado que o momento para denunciar ocorre no prazo para contestar (art. 71 do CPC), revelando o desacerto do raciocínio. Diante da revogação da Lei 1.711/52, não há como se condicionar a aplicação do instituto ao trânsito em julgado da sentença condenatória ou, por falta de previsão legal, sequer a mera condenação com a pendência de julgamento de recurso.

Com efeito, a teoria restritiva não se amolda à previsão do inciso III, do art. 70, do Código de Processo Civil, que expressamente prevê a "ação de regresso", sendo certo não existir possibilidade de afastar a introdução de fato novo, o que impediria a realização

\footnotetext{
${ }^{233}$ Trata-se de posição revista, dado que anteriormente o administrativista considerava cabível a denunciação (Curso de direito administrativo, p. 692).

${ }^{234}$ Direito administrativo brasileiro, p. 594.
} 
da própria intervenção de terceiro ${ }^{235}$. Com efeito, terá que haver, na lide secundária, ao menos a afirmação da existência do direito de regresso e dos fatos que o constituem, pelo denunciante, de modo que se revela incongruente essa restrição absoluta. Isso também não violará o princípio da economia processual, que não pode ser visto como mera redução dos atos processuais a serem praticados. Num sentido mais amplo, pode-se entender que, assim se alcançará, de forma muito mais efetiva, o escopo de solução de duas demandas, num único processo, por meio de uma única instrução processual e sentença.

Cabível, pois, a aplicação, nessas contendas, da denunciação da lide, que se afina com a concepção ampliativa, não sendo aceitável conferir interpretação restritiva aos dispositivos legais que regulam a matéria. Não é possível ignorar a existência de duas demandas, havendo relação de prejudicialidade entre elas e não tendo o autor que ajuizou ação apenas em face do Estado de provar a culpa ou o dolo do agente público. Além disso, o princípio da economia processual não é vulnerado, pois haverá concentração de atos, que não precisarão ser repetidos; isso ocorreria caso não se permitisse a aplicação do instituto. Sequer a preservação do princípio da celeridade processual pode ser invocado para criticar a denunciação também nessa hipótese específica, até porque "o maior responsável pela demora neste processo não é a denunciação da lide, mas a presença do Estado na relação

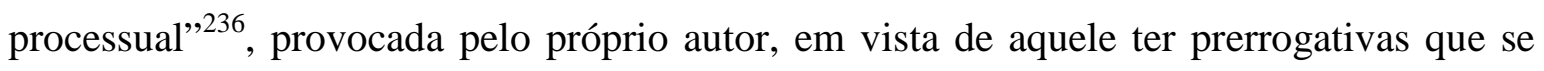
marcam por uma série de privilégios.

Ressalve-se, no entanto, posição distinta, sustentando não ser possível denunciar a lide nos processos que objetivem pretensão de condenação por responsabilidade civil do Estado, por considerar oportuna outra modalidade de intervenção de terceiro, o chamamento ao processo. Funda-se esse raciocínio na circunstância de a hipótese enquadrar-se na previsão do inciso III, do art. 77, do Código de Processo Civil, o que, por exclusão, em razão da especialidade, afastaria a denunciação. Se assim sucedesse e ambos

\footnotetext{
${ }^{235}$ Ao tratar da questão, José Manoel de Arruda Alvim Netto sustenta o cabimento da denunciação da lide, afirmando não ser possível, em linha de princípio, generalizar a impossibilidade de se introduzir fato novo (culpa), até porque "não é incomum, na ordem prática, que se procure responsabilizar o Estado imputando comportamento culposo a seu funcionário" (Código de Processo Civil Comentado, p. 134).

${ }^{236} \mathrm{Cf}$. Alexandre Freitas Câmara, que expõe, ainda, que "as prerrogativas processuais do Estado são tantas que acabam por alongar excessivamente a duração dos processos em que ele participa”. Também refuta a violação ao princípio da economia processual, por considerar "que o processo deve ser capaz de produzir o máximo de resultado com o mínimo de dispêndio de tempo e energias" (Intervenção forçada de terceiros $e$ responsabilidade civil do Estado, p. 19).
} 
fossem condenados, a vítima poderia, ao pleitear o cumprimento de sentença, apontar se preferiria dirigir a execução contra o Estado ou contra o agente causador do dano ${ }^{237}$.

Discordamos, todavia, dessa posição, de vez que, embora a vítima do dano possa exigir do Estado e também do agente público a reparação do dano, trata-se de um caso típico de direito de regresso, não de solidariedade. Além disso, o pagamento da dívida pelo Estado, em cumprimento de sentença condenatória, nem sempre lhe conferirá o direito de exigir seu reembolso pelo agente público, em virtude da distinta natureza da responsabilidade de cada qual, ou seja, a responsabilidade objetiva do Estado pode restar caracterizada e a responsabilidade subjetiva do agente público não, se a prova da culpa ou do dolo não for demonstrada. Diante disso, não existe efetiva solidariedade - que não se presume, devendo resultar da lei ou da vontade das partes (art. 265 do CC) - mas apenas direito de regresso.

Por essas perspectivas, o Estado tem direito de regresso, pois ele e o funcionário público não podem ser considerados, propriamente, "devedores solidários", o que afasta a aplicação do inciso III, do art. 77, e, pois, o chamamento ao processo. Cuida-se mesmo de denunciação da lide, devendo o Estado, em ação regressiva, buscar o ressarcimento do prejuízo.

Assim, entendemos ser cabível a denunciação da lide do Estado ao funcionário, dado que a introdução de fato novo é da própria essência do instituto e o processo não objetiva apenas atender aos interesses do autor, mas é instrumento de pacificação social. Vincula-se, outrossim, ao princípio da economia processual e não ofende o da celeridade, de vez que não é propriamente o instituto que retarda a prestação da tutela jurisdicional, mormente em demanda em que o Estado seja parte, para a qual leva todas as prerrogativas processuais que possui.

5.4. Da denunciação da lide do segurado ao segurador. Existem contratos de seguro de responsabilidade civil para prevenir e garantir danos causados em acidente de veículos, bem como contratos de seguro de danos ocorridos no exercício de algumas

${ }^{237}$ Alexandre Freitas Câmara, Intervenção forçada de terceiros e responsabilidade civil do Estado, p. 22-24. 
profissões, como as de médicos, dentistas, auxiliares de medicina, advogados, contadores, auditores, engenheiros, arquitetos e agrônomos.

A partir do que se verifica nos foros, exemplo de maior aplicação prática de denunciação da lide, fundada no art. 70, III, é a associada a seguro de responsabilidade civil, por meio do qual "o segurador garante o pagamento de perdas e danos devidos pelo segurado a terceiro" (art. 787 do CC). O beneficiário é o próprio segurado denunciante a fim de não pagar indenização por ato ilícito por ele praticado ${ }^{238}$.

Tanto é assim que, não por acaso, o art. 280 do Código de Processo Civil, com a redação da Lei 10.444/02, temperou a restrição de intervenção de terceiro no procedimento sumário, permitindo a denunciação da lide, desde que fundada em contrato de seguro. Trata-se de incentivo a essa modalidade de intervenção de terceiros, apesar de ela obstar, em tese, o andamento do processo, ensejando a ampliação objetiva e subjetiva da demanda. Isso não se ajusta à celeridade que se busca conferir ao rito, razão pela qual não se admite reconvenção, bem como ação declaratória incidental, oposição, nomeação à autoria e chamamento ao processo. Ademais, a ausência de denunciação poderia ensejar fraude mercê do conluio entre as partes com a definição de indenização em valor elevado e que, depois, seria reclamada regressivamente da seguradora. Esta, caso questionasse o valor, poderia levar ao refazimento total do processo com óbvios prejuízos à atividade jurisdicional. Por conta disso, a economia processual e a segurança são prestigiadas com a denunciação.

Haverá, provavelmente, a introdução de fato novo, o que, a nosso ver, não impede a denunciação da lide à seguradora ${ }^{239}$. Na prática, essa é a tendência, não se obstaculizando a aplicação do instituto em demandas em que a vítima de acidente de

\footnotetext{
${ }^{238}$ Sergio Cavalieiri Filho explica que "o segurado não contrata o seguro em benefício da vítima, mas sim em benefício próprio, para não desfalcar o seu patrimônio das consequências civis do que venha a causar a outrem" (Programa de responsabilidade civil, p. 446).

${ }^{239}$ Em sentido contrário, Rui Stoco entende não ser admissível a denunciação da lide à seguradora, por força de a responsabilidade dela ser "contratual com o segurado, enquanto este figura como réu, por força de sua responsabilidade extracontratual ou aquiliana. Ora, em casos tais introduz-se na causa fundamento diverso e novo, posto que enquanto na lide principal discute-se a culpa (lato sensu) do causador do dano, na lide paralela há que se discutir, objetivamente, a obrigação da seguradora estabelecida em contrato. Essa inovação da lide ofende os princípios processuais da imutabilidade do pedido e da causa de pedir, após angularizada a ação, nos termos do art. 294 do CPC" (Acidentes de trânsito - denunciação da seguradora à lide, p. 121).
} 
trânsito, por exemplo, ajuíza ação em face do causador do dano para ser ressarcida dos prejuízos ocasionados.

A reforçar a admissibilidade da incidência do instituto, o art. 787 do Código Civil estabelece que, "no seguro de responsabilidade civil, o segurador garante o pagamento de perdas e danos devidos pelo segurado a terceiro", devendo o segurado, intentada a ação, dar ciência da lide ao segurador, nos termos do $\S 3^{\circ}$ deste dispositivo. É certo que essa ciência que o segurado deve dar ao segurador não se confunde com a denunciação da lide. $\mathrm{Na}$ realidade, trata-se de providência que incumbe ao segurado tomar diretamente, podendo, ainda, denunciar-lhe a lide, por tratar-se de hipótese de denunciação facultativa. O juiz irá aferir se estão presentes os requisitos legais e, se a denunciação for indeferida, o segurador poderá intervir no processo na condição de assistente, igualmente dele participando.

5.4.1. Da ação direta da vítima do ato ilícito em face do segurador. Caso ação indenizatória for ajuizada apenas em face do segurado, responsável por ato ilícito e este tiver contrato de seguro, será plenamente cabível a denunciação da lide ao segurador; existe, porém, controvérsia sobre a viabilidade de a vítima, sabendo do contrato de seguro, ajuizar a ação diretamente em face do segurador, seja colocando ambos no polo passivo ou apenas o segurador.

Há corrente considerando não ser cabível ação direta em face do segurador, que deverá, se for o caso, ser denunciado pelo réu segurado. Isso decorre da falta de vínculo de direito material entre a vítima do dano e o segurador, de modo que deveria ser reconhecida a ilegitimidade passiva deste, caso a ação lhe fosse eventualmente promovida.

Exceto por meio da denunciação da lide, o segurador não ficaria, portanto, obrigado a reparar o dano, em vista de não ter praticado o ato ilícito e de a força vinculante do contrato ser restrita às partes e não atingir terceiro. De acordo com a regra do art. 942 do Código Civil, os bens do responsável pela ofensa ou violação dos direitos de outrem ficam sujeitos à reparação do dano causado; assim, apenas o segurado seria responsabilizado, podendo valer-se, facultativamente, do direito de regresso. 
Não concordamos, todavia, com essa corrente, que afasta a legitimidade passiva do segurador, mesmo diante da inexistência de relação de direito material, por a vítima não ter firmado contrato de seguro e esse ser res inter alios acta. É necessário ter uma visão mais ampla do sistema, a fim de a questão ser melhor equacionada.

Vale ressaltar que os efeitos do contrato de seguro não atingem apenas as partes celebrantes, em razão de elas terem manifestado a sua vontade; podem, ainda, beneficiar terceiros como sucede, exemplificativamente, com os seguros de vida, de acidentes pessoais, de constituição de renda e de transporte de objetos para terceiros destinatários. Esses terceiros podem ser nominalmente identificados no contrato ou apenas podem ser lançadas as circunstâncias que ensejarão a vinculação deles ao ajuste. Desse modo, não é absoluta a regra de que a força vinculante do contrato restringe-se somente às partes contratantes.

Dessa forma, pode haver a celebração de contrato, no qual se estipula benefício em favor de terceiro, opondo-se não só à regra do direito romano - segundo a qual altei stipulari nemo potest -, mas também ao caráter estritamente pessoal do vínculo ${ }^{240}$. Para tanto, o contrato deve resultar de uma atribuição patrimonial gratuita, sem qualquer contraprestação da pessoa estranha à formação do vínculo contratual. Assim sendo, o beneficiário terá apenas direitos, sendo-lhe permitido exigir do segurador o cumprimento da obrigação ${ }^{241}$, ficando o beneficiário apenas sujeito às condições e normas do contrato, nos termos do parágrafo único, do art. 436, do Código Civil ${ }^{242}$.

\footnotetext{
${ }^{240}$ Clóvis Bevilaqua destaca que "a estipulação em favor de terceiro é um poderoso instrumento jurídico" e que o Código Civil brasileiro, ainda no sistema de 1916 (mantida essa parte no de 2002), considera-o "uma relação contratual sui generis, na qual a ação para exigir o cumprimento da obrigação se transfere ao beneficiário, sem aliás perdê-la o estipulante. É um caso de despersonalização dupla, tendo por ponto de conjunção o promitente, que contrata com o estipulante realizar uma prestação, que irá cumprir nas mãos do beneficiário" (Código Civil dos Estados Unidos do Brasil, p. 214).

${ }^{241}$ Existe forte tendência em admitir o ajuizamento da ação somente em face do segurador, defendendo Gustavo de Medeiros Melo ser essa a solução "mais adequada" (A ação direta do terceiro prejudicado no seguro de responsabilidade civil, p. 297). Consideramos ser possível que a ação seja ajuizada somente em face do segurador, mas parece-nos ser mais prudente que a vítima demande tanto o segurado como o segurador, mas não se trata, de qualquer maneira, de litisconsórcio passivo necessário.

${ }^{242}$ Essa regra já existia no Código Civil de 1916, no art. 1.098 e, segundo Urbano Ruiz, a legitimação ativa da vítima perante o segurador, nos contratos de seguro facultativo de responsabilidade civil, "já está incorporada à lei mexicana, boliviana, colombiana, peruana, hondurenha, guatemalteca e é reconhecida de forma pacífica pelos tribunais, independentemente da lei, no Panamá e na Venezuela" (Seguro de responsabilidade civil,, p. 149), de modo que não se trata de nenhuma inovação legislativa recente.
} 
Dessa maneira, a existência e validade do contrato não dependem da vontade do terceiro beneficiado, "mas somente sua eficácia, subordinada que é à aceitação"243. A eficácia do contrato dependerá, portanto, da manifestação de anuência do terceiro, cuja vontade é essencial. Essa anuência, entretanto, não tem momento exato para ser manifestada, em vista de poder se dar até após a ocorrência da condição que torna devida a obrigação pelo segurador e de bastar a simples busca do ressarcimento.

Com propriedade, ORLANDO GOMES expõe que "a obrigação contraída pelo promitente pode ser exigida pelo estipulante ou pelo beneficiário", em razão de a estipulação ser feita em favor do terceiro. Conclui que é dispensável a intervenção do estipulante para o exercício do direito do terceiro, que "pode agir diretamente contra o promitente"244, o que evidencia a possibilidade de a vítima do dano ajuizar ação diretamente contra o segurador ${ }^{245}$.

Apesar de o resultado prático ser o mesmo, parece-nos mais técnico tratar a questão como "estipulação em favor de terceiro",246, ao invés de "substituição de responsabilidade", dado que não haverá, propriamente, a substituição dessa responsabilidade, em razão de o segurador apenas ser compelido a pagar a indenização diretamente à vítima até o limite do valor da apólice, obrigação que ele já assumiu. Permite-se apenas que a vítima exija a obrigação estipulada, mas isso não afasta a responsabilidade do segurado, até porque o segurador poderá ser insolvente e a sua responsabilidade ser restrita ou eventualmente não existir, diante, por exemplo, do não pagamento do prêmio ou do agravamento intencional do risco objeto do contrato.

\footnotetext{
${ }^{243}$ Carlos Roberto Gonçalves, Direito civil brasileiro, p. 98.

244 Contratos, n. 129, p. 166.

245 José de Aguiar Dias defende a possibilidade de a vítima ajuizar ação direta em face do segurador. Depois de discorrer sobre as teorias que disputam o mérito de explicar esse cabimento, repele a tese da assimilação da ação direta a privilégio, em razão de que por meio deste escapa-se "do rateio, ao passo que na ação direta o crédito se efetiva no patrimônio de terceiro". Critica também a teoria do enriquecimento ilícito "porque não se configuram, na situação em que a ação direta intervém, os extremos do enriquecimento, mas somente a sua possibilidade e, assim, a ação não é de reintegração, mas preventiva". Afirma que a ação direta "tem fisionomia própria", reputa "errôneo supor que o seguro de responsabilidade civil ou de acidente de trabalho envolvam uma estipulação em favor de terceiro" e conclui, amparado nas considerações de Isaac Halperin, que se trata "de substituição de responsabilidade", pois tem "o propósito de assegurar a certos credores a satisfação dos seus créditos mediante o crédito que o devedor tem em relação a terceiros”, evitando-se inútil intermediário e "que o produto do crédito em poder de terceiro venha a ser desviado do seu destino lógico e material" (Da responsabilidade civil, p. 1.137-1.140).

${ }^{246} \mathrm{Cf}$. Humberto Theodoro Júnior, O novo Código Civil e as regras heterotópicas de natureza processual, $\mathrm{p}$. 25.
} 
Esse terceiro, que obterá a vantagem patrimonial, não precisa ser identificado no ato da celebração do contrato, sendo suficiente que ele seja determinável no momento do sinistro $^{247}$. Deverá haver somente a coincidência entre o lesado, titular da pretensão deduzida em juízo, e o autor da ação.

Essa faculdade, atribuída à vítima do dano, decorre da preponderância que tem sido conferida ao interesse social da garantia de indenização aos prejudicados ${ }^{248}$. Fica, em segundo plano, o interesse individual da proteção do patrimônio do segurado, cujos bens se preservam, no limite do valor da apólice. De qualquer modo, caso a ação seja promovida apenas em face do segurado, o que é o mais comum, até mesmo em vista de a vítima normalmente desconhecer a cobertura securitária, ele poderá denunciar a lide, de modo que, após cumprir a obrigação, terá o seu direito de regresso resguardado.

Nesse sentido, as decisões do Superior Tribunal de Justiça têm conferido à vítima a faculdade de ajuizar ação tanto contra o causador do ato ilícito, quanto contra a seguradora, reconhecendo a legitimidade passiva desta ${ }^{249}$.

Destaca-se, ademais, que ordenamentos específicos para determinados tipos de relações jurídicas e acidentes permitem à vítima acionar diretamente o segurador.

\footnotetext{
${ }^{247}$ Arnaldo Rizzardo diz ser possível "estipular a obrigação em favor da pessoa indeterminada, mas não em favor da pessoa indeterminável”. Exemplifica que, no seguro de acidentes em favor de terceiros, a indeterminação diz respeito à pessoa que receberá a indenização, mas torna-se conhecida quando ocorre o sinistro (Contratos, p. 150).

${ }^{248}$ V. Ernesto Tzirulnik, O futuro do seguro de responsabilidade civil, p. 72-77; e Caio Mário da Silva Pereira, ao admitir ser a indenização pleiteada diretamente contra o segurador, reconhecendo caber "ação direta da vítima contra o segurador do responsável, porque se tem este o dever de ressarcir o dano, a vítima estaria desguarnecida na hipótese de um conluio entre aqueles, ou restaria não indenizada se o responsável é insolvente e não procede contra o segurador" (Responsabilidade civil, n. 269, p. 331).

249 "Civil e processual civil. Contrato de seguro. Ação ajuizada pela vítima contra a seguradora. Legitimidade passiva ad causam. Estipulação em favor de terceiro. Doutrina e precedentes. Recurso provido. I- As relações jurídicas oriundas de um contrato de seguro não se encerram entre as partes contratantes, podendo atingir terceiro beneficiário, como ocorre com os seguros de vida ou de acidentes pessoais, exemplos clássicos apontados pela doutrina. II - Nas estipulações em favor de terceiro, este pode ser pessoa futura e indeterminada, bastando que seja determinável, como no caso do seguro, em que se identifica o beneficiário no momento do sinistro. III - O terceiro beneficiário, ainda que não tenha feito parte do contrato, tem legitimidade para ajuizar ação direta contra a seguradora, para cobrar a indenização contratual prevista em seu favor" (REsp 401.718/PR, Rel. Min. SÁLVIO DE FIGUEIREDO TEIXEIRA, $4^{\mathrm{a}}$ Turma, J. 03/09/2002)". V., ainda, REsp 294.057/DF, Rel. Min. RUY ROSADO DE AGUIAR, $4^{\text {a Turma, }}$ J.28/06/2001; REsp 228.840/RS, Rel. Min. CARLOS ALBERTO MENEZES DIREITO, $3^{\text {a }}$ Turma, J. 26/06/2000.
} 
Assim, a possibilidade da ação direta já era prevista no art. 108 do Código Brasileiro do Ar (Decreto-lei 483/38), segundo o qual "quem tiver direito à reparação do dano exerce, nos limites da soma que lhe competir, direito próprio sobre a garantia prestada pelo responsável”. O direito aeronáutico passou a ser disciplinado pelo Código Brasileiro da Aeronáutica (Lei 7.565/86), que alterou a redação do referido dispositivo, mas manteve a essência da tese, ao estabelecer, no art. 286, que "aquele que tiver direito à reparação do dano poderá exercer, nos limites da indenização que lhe couber, direito próprio sobre a garantia prestada pelo responsável (artigos 250 e 281, Parágrafo único)”. No direito aéreo, portanto, a vítima do dano tem garantida a indenização, podendo, por direito próprio, voltar-se contra o garantidor.

É o que se passa também no parágrafo único, do art. 788, do Código Civil, que prevê a possibilidade de a seguradora ser diretamente demandada pela vítima do dano, porém apenas "nos seguros de responsabilidade legalmente obrigatórios" 250 . Essa distinção decorre da natureza previdenciária do seguro obrigatório, como sucede, por exemplo, em relação aos danos pessoais causados por veículos automotores de vias terrestres (DPVAT). Diante da natureza social e assistencial desse seguro obrigatório, basta a ocorrência do dano, sendo irrelevante não só perquirir sobre eventual culpa, vencimento da apólice do seguro, falta de pagamento do prêmio (súmula 257 do STJ) mas também identificar o causador do dano, razão pela qual a vítima pode demandar - e só pode demandar diretamente o segurador.

Pondere-se, de qualquer modo, que essa hipótese de seguro obrigatório, em que o segurador pode ser demando diretamente, amolda-se melhor ao chamamento ao processo, em vista de a vítima do dano, dada a disposição legal e a estrutura do contrato, ter relação jurídica com o causador do dano e com o segurador ${ }^{251}$.

O raciocínio da ação direta está, aliás, em sintonia com a regra do art. 101, II, do Código de Defesa do Consumidor, que também possibilita que o segurador seja chamado

\footnotetext{
${ }^{250}$ Gelson Amaro de Souza ressalta que, nos seguros de responsabilidade legalmente obrigatórios, a "responsabilidade do segurador passou a ser a principal, enquanto a do segurado se tornou subsidiária, surgindo somente quando o segurador não tiver condições de solver o valor do seguro, ou quando a indenização ultrapassar o valor do seguro" (Cumprimento de sentença diretamente contra o denunciado, $\mathrm{p}$. 24).

${ }^{251}$ Cf. José Manoel de Arruda Alvim Netto, Araken de Assis e Eduardo Arruda Alvim (Comentários ao código de processo civil, p. 440-441).
} 
ao processo pela própria vítima. Nesse caso, o legislador tratou da intervenção de terceiro como chamamento ao processo, colocando o segurado e o segurador na condição de devedores solidários, o que deve ser restrito a demandas de relação de consumo, conforme abordaremos em seguida. De qualquer modo, o objetivo, independentemente da denominação, é também trazer o segurador para responder diretamente ao que sofreu a lesão causada pelo ato ilícito.

5.5. Das outras hipóteses de denunciação da lide. $\mathrm{Na}$ prática, até pela amplitude do dispositivo, a previsão legal do inciso III, do art. 70, do Código de Processo Civil é a que possui, seguramente, maior aplicabilidade, existindo, além das hipóteses de que já se tratou, ainda vários exemplos que podem ser trazidos, como será apontado, sem qualquer preocupação de exauri-los.

Revela-se corriqueira a denunciação quanto às pretensões de reparação civil movidas por entidade hospitalar - que vise receber a remuneração pela prestação de serviço - em face de segurado de plano de saúde, quando o contrato com este proporcionar a cobertura de assistência médico-hospitalar. Muitas vezes, o plano de saúde indevidamente nega cobertura para determinadas despesas, o que leva o hospital a buscar o ressarcimento do paciente ou de seu representante, acabando este por denunciar aquele, em decorrência de sua responsabilidade contratual.

O instituto também se aplica no caso de o cessionário de crédito, com direito de regresso contra o cedente, ficar vinculado aos efeitos da sentença e ser responsabilizado se o crédito não existir. $\mathrm{O}$ mesmo sucede na responsabilidade do endossatário mandatário em relação ao endossante mandante, que recebeu o título para cobrança e protesto ${ }^{252}$.

\footnotetext{
${ }^{252}$ Cf. o seguinte aresto do Superior Tribunal de Justiça: "Denunciação da lide. Ação de indenização. Art. 70, III, do Código de Processo Civil. Relação entre mandante e mandatário em caso de endosso para a cobrança e protesto de título. 1. O endossatário-mandatário responde perante o endossante-mandante pelos atos que praticar no cumprimento do mandato, pertinente, portanto, a incidência do art. 70, III, do Código de Processo Civil, deferida corretamente a denunciação. 2. Recurso especial não conhecido" (REsp 332.839/MG, Rel. Min. CARLOS ALBERTO MENEZES DIREITO, 3 ${ }^{\text {a }}$ Turma, J 26/08/2002, DJ 25/11/2002, p. 229). Recentemente, a súmula 475 do Superior Tribunal de Justiça estabeleceu que "responde pelos danos decorrentes de protesto indevido o endossatário que recebe por endosso translativo título de crédito contendo vício formal extrínseco ou intrínseco, ficando ressalvado seu direito de regresso contra os endossantes e avalistas". Dessa maneira, existe a possibilidade de o endossatário denunciar a lide ao endossante ou, após ser condenado, mover ação autônoma de regresso, por se tratar de hipótese de denunciação facultativa.
} 
O mesmo igualmente se verifica nas relações de consumo, existindo hipótese em que o fornecedor pode trazer ao processo o seu segurador - caso tenha contratado seguro de responsabilidade civil - por meio do chamamento ao processo e pela denunciação da lide (art. 101, II, CDC) ${ }^{253}$, vedando-se, porém, que o segurado repasse sua obrigação ao ressegurado.

\subsection{Da intervenção de terceiro em ação voltada à fixação da obrigação} alimentar. Questão intrincada e controvertida é a definição de qual modalidade de intervenção de terceiro é a referida pelo art. 1.698 do Código Civil, ao estabelecer que, "se o parente, que deve alimentos em primeiro lugar, não estiver em condições de suportar totalmente o encargo, serão chamados a concorrer os de grau imediato; sendo várias as pessoas obrigadas a prestar alimentos, todas devem concorrer na proporção dos respectivos recursos, e, intentada ação contra uma delas, poderão as demais ser chamadas a integrar a lide".

Antes de buscar identificar qual das figuras de intervenção de terceiro melhor se amolda à hipótese legal, é necessário destacar que, quando várias pessoas têm ou podem ter a obrigação alimentar em relação a outrem, o dever de cumprimento não gera obrigação solidária, diante do silêncio da lei. Assim só não o é em relação ao idoso (art. 12 do Estatuto do Idoso).

O credor de alimentos não pode escolher livremente um dos co-obrigados para exigir o valor integral de suas necessidades, até mesmo porque é necessário observar a

\footnotetext{
${ }^{253}$ Kazuo Watanabe afirma que "o fornecedor demandado poderá convocar ao processo o seu segurador, mas não para o exercício da ação incidente de garantia que constitui a denunciação da lide (conforme comentário ao art. 88, supra) e sim para ampliar a legitimação passiva em favor do consumidor o que se dá através do instituto ao chamamento ao processo, disciplinado no Código de Processo Civil, nos arts. 77 a 80. Com a norma do art. 101 do Código o elenco do art. 77, CPC, fica ampliado para nele ficar abrangido o segurador do fornecedor de produtos e serviços, que passa a assumir a condição de co-devedor perante o consumidor. $\mathrm{O}$ dispositivo traz expressa alusão ao art. 80, CPC, que prevê a condenação de todos os co-devedores, reconhecendo 'em favor do que satisfizer a dívida' o benefício do título executivo para exigir a dívida, se for o caso 'por inteiro do devedor principal ou de cada um dos co-devedores, a sua quota, na proporção que lhes tocar'. Certamente, na relação entre segurador e segurado pela natureza do contrato que confere ao segundo o benefício da cobertura securitária em troca do pagamento ao primeiro do prêmio correspondente, a título de contra-prestação não haverá lugar para essa cobrança regressiva do segurador contra o segurado. $\mathrm{O}$ chamamento ao processo portanto amplia a garantia do consumidor e ao mesmo tempo possibilita ao fornecedor convocar desde logo sem a necessidade de ação regressiva autônoma o segurador para responder pela cobertura securitária prometida" (Código brasileiro de defesa do consumidor comentado pelos autores do anteprojeto, p. 797-798).
} 
ordem do rol dos parentes que devem alimentos (art. 1.696 do CC). Sua natureza é divisível, na proporção da possibilidade dos alimentantes, a fim de atender às necessidades do alimentado. Dessa maneira, se o parente da classe mais próxima não tiver condição financeira suficiente para suportar integralmente a obrigação alimentar, vários outros parentes poderão ser obrigados a prestá-la, fazendo-o de conformidade com seus recursos, não havendo responsabilidade em relação à totalidade da obrigação alimentar. Assim sendo, cada um dos obrigados deverá responder de acordo com suas possibilidades, sendo que cada quota constitui dívida distinta. Se, todavia, o parente mais próximo tiver condições de arcar com a totalidade das necessidades, a questão encerra-se por aí e ninguém mais deverá ser molestado.

A tentativa de alcançar outro que não o parente mais próximo gera, sem dúvida, caso de intervenção de terceiro provocada, em vista de o terceiro ser chamado ao processo por iniciativa de uma das partes. Para tanto, basta verificar que o legislador se utiliza das expressões "serão chamados" e "ser chamadas", de modo que o dispositivo se afasta das modalidades de intervenção voluntária, restando, como opções, a nomeação à autoria, a denunciação da lide e o chamamento ao processo.

Com certeza, não se cuida de nomeação à autoria, apesar de a modalidade ser provocada. Na realidade, a fixação de alimentos não tem qualquer sintonia com o instituto, por meio do qual se busca a correção do polo passivo, excluindo-se o réu e incluindo-se o legitimado. A divergência persiste, portanto, em relação à denunciação da lide e ao chamamento ao processo, sendo que trataremos, primeiramente, das críticas feitas a ambas as figuras para, posteriormente, destacarmos correntes doutrinárias que defendem cada uma das modalidades.

O art. 1.698 do Código Civil não se ajusta, propriamente, às hipóteses de denunciação da lide previstas no art. 70 do Código de Processo Civil, porque não tem qualquer ligação com evicção e posse direta, sendo que também não se invoca relação de garantia e não se exerce direito de regresso. Não possui, ademais, as características de assistência à defesa e de reembolso, típicas dessa modalidade de intervenção vigente no sistema pátrio. 
A pessoa não é chamada a integrar a lide para defender, ainda que indiretamente, os interesses do alimentante, mas o seu próprio. Ela pode contribuir para convencer e demonstrar que o valor das necessidades do alimentado é inferior ao pleiteado, mas pode também provar - ao contrário do que ocorreria na relação processual entre o denunciante e o denunciado - que o parente devedor de alimentos em primeiro lugar tem integral condição financeira de suportá-los por inteiro sem a necessidade de a obrigação ser complementada, até mesmo porque se afasta do caráter de reembolso, não havendo que se cogitar de regresso, dado que as obrigações são divisíveis e distintas. Assim, pode empenhar-se, inclusive, para agravar a situação do outro parente, o qual, por sua vez, não terá como postular o reembolso do valor da obrigação.

Também não se encaixa o art. 1.698 do Código Civil em qualquer dos incisos do art. 77 do texto processual. Não se trata de relação jurídica mantida com fiador e não há solidariedade entre os obrigados a prestar alimentos, já que não se pode exigir a obrigação integral de qualquer dos obrigados, por existir mera obrigação divisível (art. 257 do CC), supletiva e complementar dos demais alimentantes, em vista da incapacidade de o parente, que deve alimentos em primeiro lugar, suportar o encargo totalmente. A partir do texto legal e das características, portanto, não se trata de chamamento ao processo.

Acrescente-se, ainda, que apenas o réu pode pleitear o chamamento ao processo (art. 78 do CPC), porém o art. 1.698 do Código Civil não estabelece quem pode chamar os demais parentes, de modo que, se o legislador não fez essa distinção, não é possível interpretar restritivamente e limitá-la apenas ao réu alimentante, embora na prática seja provavelmente a situação mais corriqueira. A interpretação da primeira parte da regra é clara nesse sentido, ao prever que "serão chamados a concorrer os de grau imediato", o que poderá ser feito diretamente pelo autor, diferentemente da segunda parte, que estabelece o chamamento pelo réu, ao dispor que, "intentada ação contra uma delas, poderão as demais ser chamadas a integrar a lide".

O autor tem a liberdade de escolher os réus. Pode demandar apenas o parente que deve alimentos em primeiro lugar, como também, caso este não tenha condições de arcar integralmente com a obrigação, o responsável em grau imediato. 
Essa cumulação subjetiva atende ao princípio da economia processual - tão valorizado em nosso sistema - e tem também o efeito de vincular o cumprimento da obrigação desde a citação. Isso é extremamente benéfico ao alimentado, que não precisará aguardar o desfecho indefinido da demanda movida em face do parente que deve alimentos em primeiro lugar para, somente após caracterizada a impossibilidade de este suprir de modo satisfatório a necessidade daquele, voltar-se contra os demais obrigados. $\mathrm{O}$ alimentado evita, portanto, o risco de não ter suas necessidades integralmente satisfeitas, tendo que, posteriormente, voltar-se contra outros co-obrigados.

Assim, entendemos não ser tecnicamente possível considerar que se trata de qualquer das hipóteses de intervenção de terceiro elencadas no texto processual.

Não se cuida, outrossim, de litisconsórcio necessário, em razão de o credor não estar obrigado a litigar com todos os co-obrigados. Na realidade, o alimentado pode não ter interesse em ajuizar a ação em face de determinado parente, em decorrência do constrangimento que isso representaria e da plena ciência de que determinado co-obrigado tem melhores condições financeiras de complementar, em caráter subsidiário, a prestação alimentar. Dessa maneira, não é razoável impor que, chamados os avós paternos, também o sejam os avós maternos ${ }^{254}$, porém é certo que os avós paternos têm o direito de chamar a integrar a lide os maternos, nos termos da parte final do art. 1.698 do Código Civil, independentemente da vontade do alimentado, por estarem no mesmo grau de responsabilidade.

Parece-nos que se trata de litisconsórcio passivo facultativo sucessivo ${ }^{255}$, em vista de haver uma comunhão de obrigações relativamente à lide (art. 46, I, do CPC). Ressalvese, no entanto, que a demanda não precisará ser decidida de modo uniforme para todos os litisconsortes, sendo, portanto, um litisconsórcio simples ${ }^{256}$, em oposição ao unitário.

\footnotetext{
${ }^{254}$ Existe divergência jurisprudencial sobre essa questão no Superior Tribunal de Justiça. Contra a hipótese de litisconsórcio necessário: REsp 50.153/RJ, Rel. Min. BARROS MONTEIRO, $4^{\text {a }}$ Turma, J 12/09/1994 . A favor dela: REsp 958.513/SP, Rel. Min. ALDIR PASSARINHO JUNIOR, 4 $4^{\mathrm{a}}$ Turma, J 22/02/2011.

${ }^{255}$ Cf. Maria Berenice Dias, Manual de direito de família, p. 482.

${ }^{256}$ Nesse mesmo sentido, Fredie Didier Júnior afirma, corretamente, que nada impede "que o alimentando proponha de logo a demanda contra todos os devedores-comuns que estejam no mesmo grau, em litisconsórcio facultativo simples - a sentença fixará a proporção com que cada um dos obrigados deverá concorrer. É possível, até mesmo, a propositura de demanda contra devedores que se encontrem em graus diversos (mãe e avó, p. ex.; arts. 1.696 e 1.697 do CC-2002), valendo-se o autor do instituto do litisconsórcio facultativo eventual" (A nova intervenção de terceiro na ação de alimentos (art. 1.698 do Código Civil, de 2002), p. 17).
} 
Poderá cada obrigado ser condenado a pagar valor diverso; ou um litisconsorte ser condenado e o outro não.

A par dessas considerações, há corrente sustentando que a figura de intervenção de terceiro regulada no art. 1.698 do Código Civil é a denunciação da lide, por força de haver uma ordem sucessiva de legitimidade para prestar a obrigação alimentar ${ }^{257}$.

O chamamento ao processo é figura mais aceita do que a denunciação, muito possivelmente porque a utilização do verbo "chamar" já liga, ainda que timidamente, a previsão legal ao instituto. Isso, todavia, parece-nos uma simples coincidência, até mesmo porque, se essa fosse a intenção, o legislador teria certamente previsto a questão de maneira mais minuciosa.

A defender essa modalidade ${ }^{258}$, sustenta-se que a existência de vários coobrigados, ainda que não exista solidariedade, enquadra-se na regra do art. 77 , III, do Código de Processo Civil. Assemelha-se, ainda, ao chamamento ao processo, em vista de a intervenção se dar em benefício do próprio alimentado, como sucede em relação ao autor na demanda em que ocorre tal chamamento.

Ampliando o termo "solidariedade" e flexibilizando o referido dispositivo, CÁSSIO SCARPINELLA BUENO diz que o caso "é de responsabilidade subsidiária a ser exercida consoante as 'forças' de cada um dos responsáveis pelo pagamento dos alimentos", em razão do que "o chamamento ao processo é instituto que bem realiza, processualmente, este regime de direito material". Considera, ademais, "que a sentença que julgar a ação possa também ter força executiva em face de um dos co-obrigados (CPC, art. 80)", porém reconhece a dificuldade do tema, concluindo que o mais importante é o

257 Cf. Renan Lotufo, ao comentar acórdão do Tribunal de Justiça do Rio Grande do Sul (AC 70.001.770.171) e afirmar que existe "obrigação solidária entre os do grau sucessivo, remanescendo com o autor o direito de escolha contra quem direcionar o pedido, facultando ao 'eleito' o direito regressivo, mediante denunciação à lide". Completa que "caberá a jurisprudência impedir que o exercício da denunciação não seja um entrave e que impeça o normal andamento do processo alimentar, como buscou fazer o acórdão em exame" (Alimentos - obrigação avoenga, p. 78). Parece-nos equivocado esse raciocínio, por a obrigação alimentar não ser solidária e, caso o fosse, afinar-se-ia melhor ao chamamento ao processo.

${ }^{258}$ Cf. Humberto Theodoro Júnior, O novo Código Civil e as regras heterotópicas de natureza processual, $\mathrm{p}$. 30-32; Antonio Carlos Mathias Coltro, Alimentos no Código Civil de 2002, p.109-112. 
alimentado poder "ver satisfeito, da maneira mais completa possível, o direito material (a necessidade de receber alimentos) que motivou seu ingresso em juízo"259.

Ocorre, todavia, que esses fundamentos não nos convencem quanto à aplicação de qualquer dessas modalidades de intervenção de terceiro. Em relação à denunciação da lide, não se ajusta a qualquer dos incisos do art. 70 do texto processual; não existe relação de garantia ou direito de regresso; os alimentos são irrepetíveis; e não estão presentes as características do instituto de assistência à defesa do denunciante e de reembolso. Quanto ao chamamento ao processo, não se amolda ao disposto no art. 77 do Código de Processo Civil; a obrigação alimentar não tem caráter de solidariedade, mas de subsidiariedade; o próprio autor pode requerer que o parente co-obrigado intervenha. Assim, há, seguramente, muito mais fundamentos para distanciar essas figuras da previsão de direito material do que para aproximá-las.

Diante da dificuldade de se precisar em qual modalidade de intervenção de terceiro o art. 1.698 do Código Civil enquadra-se, torna-se cada vez mais forte uma nova categoria, que não possui previsão no texto processual ${ }^{260}$. Assim, entendemos que se cuida de uma figura anômala de intervenção de terceiro provocada ${ }^{261}$, criada pelo legislador civil, o que explica, provavelmente, por que não se ajusta aos contornos da denunciação da lide e do chamamento ao processo, já que se buscou, sem rigor processual, instrumento que viabilizasse a satisfação da prestação alimentar, atendendo integralmente aos interesses do alimentado.

\footnotetext{
${ }^{259}$ Partes e terceiros no processo civil brasileiro, p. 287-292.

${ }^{260}$ Nesse sentido, Daniel Amorim Assumpção Neves considera que se trata "de nova espécie de intervenção de terceiro, criada pelo direito material", "que não se confunde com nenhuma daquelas previstas no Capítulo IV do Título II do Livro I do Código de Processo Civil" (Intervenção de terceiros e a ação de alimentos, p. 763-765); Fredie Didier Júnior diz que se trata de "modalidade interventiva nova: não devemos tentar 'enquadrá-la' em nenhuma das espécies de intervenção de terceiro até então existentes" (A nova intervenção de terceiro na ação de alimentos (art. 1.698 do Código Civil, de 2002), p. 14); Milton Paulo de Carvalho Filho sustenta que "a nova figura de natureza processual - chamamento para integrar a lide - criada pela lei civil, não é igual a nenhuma daquelas de intervenção de terceiros previstas no Código de Processo Civil". Conclui que o legislador civil "não se preocupou com a necessidade de enquadrá-la em alguma das hipóteses legais de intervenção de terceiros, mas em atender o direito material da parte, especialmente, tendo em vista o interesse em jogo por se tratar de ação de alimentos" (in Código civil comentado, coord. Cezar Peluso, p. 1.929-1.931); e Luiz Guilherme da Costa Wagner Junior afirma "que o art. 1.698 do CC criou uma nova modalidade de intervenção de terceiro" (Considerações sobre a intervenção de terceiros trazida no art. 1.698 do CC: 'A questão da complementação dos alimentos pelos parentes', p. 358).

${ }^{261}$ Yussef Said Cahali já a tratou de litisconsórcio sui generis (Dos alimentos, p. 157).
} 


\subsection{Das limitações da denunciação da lide no Código de Defesa do}

Consumidor. O cabimento da denunciação nas ações que versem sobre relação de consumo é controverso e deve ser enfrentado logicamente à luz das regras do Código de Defesa do Consumidor, de vez que se caracteriza como lei especial, socorrendo-se do Código de Processo Civil somente nos casos omissos e desde que haja compatibilidade entre o preceito a ser usado e os princípios da legislação a ser suprida.

A legislação consumerista caracteriza-se por proteger o consumidor, em vista de ele ser a parte mais vulnerável na relação de consumo (art. $4^{\circ}$ da Lei 8.078/90). Busca-se, assim, compensar a hipossuficiência do consumidor, promovendo equilíbrio econômico e jurídico, a fim de assegurar isonomia entre as partes.

Para tanto, fixaram-se regras de proteção, não só no plano de direito material, mas também no de direito processual. No campo do processo, destacam-se as normas voltadas à facilitação da defesa dos direitos do consumidor, de maneira ampla, como a inversão do ônus da prova a seu favor e a desconsideração da personalidade jurídica da sociedade para imputar responsabilidade diretamente aos sócios (arts. $6^{\circ}$, VIII, e 28 do CDC).

Além dessas previsões, existe uma tendência genérica de não se admitir a intervenção de terceiros nas lides ajuizadas por consumidores, valorizando sua proteção, em vista de sua vulnerabilidade, e o efetivo acesso à justiça, por meio de um processo célere e eficaz. Prestigia-se, portanto, o direito de o consumidor obter uma decisão rápida nas demandas em que é parte, sem dilações, que seriam, invariavelmente, causadas pela intervenção de terceiros de interesse do demandado, em razão de postergar a prestação da tutela jurisdicional.

A reforçar a busca de um processo mais célere e simples, basta atentar que a Lei 8.078/90 estabeleceu, como regra, a responsabilidade objetiva dos produtores e fornecedores da cadeia produtiva (arts. 12 e 14 do CDC). Assim, eles respondem, independentemente de culpa, pela reparação do dano proveniente de acidentes de consumo, de vícios na qualidade ou quantidade dos mesmos ou de defeitos relativos à prestação dos serviços. Essa particularidade possui pertinência, especialmente para a denunciação da lide, dado que a culpa do denunciado, muitas vezes, é fato relevante para a decisão da ação 
regressiva, o que torna incabível a intervenção de terceiro, de vez que contraria os princípios norteadores da responsabilidade objetiva.

Quanto à denunciação da lide, ela é considerada apenas nos arts. 88 e 101, II, do Código de Defesa do Consumidor, os quais vedam, expressamente, sua possibilidade nas hipóteses em que o regulam ${ }^{262}$.

5.7.1. Da previsão do art. 88 do CDC. O Código de Defesa do Consumidor estabelece, separadamente, a responsabilidade dos fabricantes que compõem a cadeia produtiva (art. 12 do CDC), do comerciante (art. 13 do CDC) e do fornecedor de serviços (art. 14 do CDC), fazendo-o na seção denominada "Da responsabilidade pelo fato do produto e do serviço". Importante destacar a distinção entre a noção de fato do produto, que é o evento danoso verificado pela utilização de produto eivado de defeito, e fato do serviço, que é o efeito danoso que ocorre na prestação de serviço.

Feitas essas necessárias considerações e distinções, destaca-se que o art. 88 estabelece que "na hipótese do art. 13, parágrafo único deste código, a ação de regresso poderá ser ajuizada em processo autônomo, facultada a possibilidade de prosseguir-se nos mesmos autos, vedada a denunciação da lide".

A partir da interpretação literal do art. 88, não há dúvida de que o não cabimento da denunciação da lide restringe-se à responsabilidade do comerciante, de acordo com a regra do art. 13. Para não obstar o deslinde da ação principal, veda-se o exercício do direito de regresso, no mesmo processo, para evitar que se retarde a prestação da tutela jurisdicional pleiteada pelo consumidor.

Segundo o disposto no art. 13, parágrafo único, do Código de Defesa do Consumidor, o comerciante que tiver indenizado o consumidor "poderá exercer o direito de regresso contra os demais responsáveis" para não ficar prejudicado. Nessa hipótese, a denunciação da lide não é de ser postulada, no prazo para contestar, a fim de ser decidida

${ }^{262}$ Fredie Didier Júnior critica a redação desses dispositivos e conclui que ambos cuidam de hipóteses de responsabilidade solidária, de modo que "a modalidade interventiva cabível é o chamamento ao processo" ( $A$ denunciação da lide e o chamamento ao processo nas causas coletivas de consumo, p. 65-66), do que, todavia, discordamos, como exporemos. 
na mesma sentença. Faculta-se ao comerciante, depois de vencido, ajuizar ação de regresso em processo autônomo ou, então, prossegir nos mesmos autos, nos termos do art. 88. Essas disposições privilegiam a satisfação do consumidor e estão em harmonia com o espírito da legislação consumerista, cujo objetivo é, nitidamente, o de favorecê-lo, evitando que a apreciação de sua pretensão seja postergada por força dos percalços da intervenção de terceiros $^{263}$.

Com efeito, o art. 88, por ser norma que cria exceção, deve ser interpretado restritivamente, de modo que o cabimento do instituto só é vedado quanto à responsabilidade do consumidor (art. 13 do CDC) ${ }^{264}$. Deve-se admiti-lo, portanto, no caso de se tratar de responsabilidade do fabricante e no do fornecedor de serviços, previstos em outros dispositivos - os arts. 12 e 14.

Acrescente-se que a responsabilidade do comerciante, de acordo com o art. 13, é meramente subsidiária, de vez que os que participavam da cadeia de produção elencados no art. 12 são os obrigados principais. A restrição à denunciação da lide está associada a essa responsabilidade subsidiária, que não ocorre nas demais hipóteses elencadas na seção "Da responsabilidade pelo fato do produto e do serviço". Consideramos que o tratamento diferenciado conferido ao comerciante no art. 13, parágrafo único, e no art. 88, em relação à vedação da denunciação da lide, é proposital, sendo descabido conferir-lhes outra interpretação.

Se estiverem presentes os requisitos do art. 70 do Código de Processo Civil, poderá haver a denunciação da lide dos que participaram do ciclo produtivo-distributivo e do fornecedor de serviços; todos responderão, "independentemenete da existência de culpa". Pondera-se que os arts. 12 e 14 do Código de Defesa do Consumidor acolheram a responsabilidade objetiva, tornando-se, portanto, desnecessária a prova da culpa; a nosso ver, todavia, isso não afasta, por si só, a faculdade de a lide ser denunciada.

\footnotetext{
263 Kazuo Watanabe destaca que essa vedação busca "evitar que a tutela jurídica processual dos consumidores pudesse ser retardada e também porque, via de regra, a dedução dessa lide incidental será feita com a invocação de uma causa de pedir distinta" (Código brasileiro de defesa do consumidor comentado pelos autores do anteprojeto, p. 760).

${ }^{264}$ Cf. José Reinaldo Lima Lopes, Responsabilidade civil do fabricante e a defesa do consumidor, p. 88. 
Assim, consideramos correto o cabimento da denunciação da lide, exceto em se tratando do comerciante. A restrição imposta pelo art. 88 do Código de Defesa do Consumidor é limitada à hipótese do art. $13^{265}$, devendo aquele dispositivo ser interpretado restritivamente. O legislador foi explícito quanto à restrição, prevendo amplamanete hipóteses de proteção ao consumidor e meios para que a tutela jurisdiconal seja prestada de maneira célere; no entanto, por não se ter preocupado em estender essa restrição à prestação de serviço ou à cadeia produtiva, não é possível que o intérprete o faça.

A orientação jurisprudencial predominante, por conseguinte, é nesse sentido ${ }^{266}$, mas essa posição quanto ao cabimento da denunciação da lide em decorrência da prestação de serviço tem sido revista e criticada. Formou-se corrente considerando que "a melhor opção exegética orienta-se no sentido de proibição ampla da denunciação da lide nas ações indenizatórias ajuizada[s] com base nos arts. 12 a 17 do CDC",267.

Sustenta-se nesse sentido não ser razoável proteger o consumidor apenas quanto à responsabilidade pelo fato do produto e não o fazer nos casos de má prestação do serviço. Conclui-se, assim, não ser cabível a denunciação da lide em todas as hipóteses, por não haver "diferença ontológica entre o fornecedor de produto e o fornecedor de serviço", para resguardar-se o consumidor hipossuficiente e evitarem-se maiores delongas no processamento da ação principal. Isso poderá acontecer em decorrência de a denunciação inaugurar discussão alheia aos interesses do consumidor "acerca da existência ou não de culpa do litisdenunciado, distorcendo o foco da ação", já que "a responsabilidade do fornecedor frente ao consumidor é de natureza objetiva, enquanto a do fornecedor para com os demais corresponsáveis é de caráter subjetivo"268.

\footnotetext{
${ }^{265}$ V., nesse mesmo sentido, Athos Gusmão Carneiro, Intervenção de terceiros, p. 76-77.

266 Cf. STJ, REsp 1.123.195/SP, Rel. Min. MASSAMI UYEDA, 3a Turma, J. 16/12/2010; REsp 1.024.791/SP, Rel. Min. ALDIR PASSARINHO JÚNIOR, 4a Turma, J. 05/02/2009; e REsp 464.466/MT,

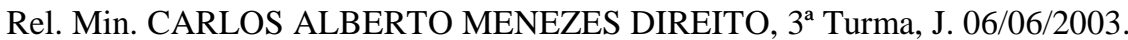

${ }^{267}$ V. REsp 1.165.279/SP, Rel. Min. PAULO DE TARSO SANSEVERINO, 3a Turma, J. 22/05/2012 (Revista Dialética de Direito Processual, v. 115, p. 192). Destaca-se neste aresto a posição da Ministra NANCY ANDRIGHI, que fez declaração de voto, entendendo incabível a denunciação e mudando seu posicionamento anterior, no qual a admitia (REsp 741.989/RS, $3^{\text {a }}$ Turma, J. 15/12/2005). No mesmo sentido, os seguintes julgados: REsp 801.691/SP, Rel. Min. RICARDO VILLAS BOAS, $3^{\text {a }}$ Turma, J. 06/12/2011; REsp 993.237/RJ, Rel. Min. HUMBERTO GOMES DE BARROS, $3^{\text {a }}$ Turma, J. 24/03/2008.

${ }^{268}$ Cf. destacou a Min. NANCY ANDRIGHI, ao declarar voto e acompanhar o do relator, Min. PAULO DE TARSO SANSEVERINO, no REsp 1.165.279/SP.
} 
Assim, a interpretação lógico-sistemática do Código de Defesa do Consumidor conduz à vedação da denunciação da lide em todas as hipóteses que versem sobre tutela individual ou coletiva dos direitos do consumidor e não apenas nas previstas pelo art. 13, parágrafo único, do Código de Defesa do Consumidor, porém permite, de qualquer modo, o exercício do direito de regresso nos mesmos autos (art. 88 do CDC) ${ }^{269}$.

Parece-nos, todavia, que essa não é a melhor interpretação, não se podendo ignorar que a responsabilidade do comerciante, estabelecida no art. 13, nos acidentes de consumo, é apenas subsidiária. O cabimento ou não da denunciação da lide gira, pois, em torno da correta interpretação que se deve conferir ao disposto no art. 88 do Código de Defesa do Consumidor $^{270}$. Segundo nosso entendimento, ela deve ser restritiva ou literal, não podendo prevalecer a lógico-sistemática, que busca, a qualquer custo, beneficiar o consumidor.

Isso posto, infere-se que a possível demora do processo, acarretada pela ampliação subjetiva e objetiva, não é suficiente para justificar a vedação da denunciação da lide: necessário realizar uma leitura de todo o sistema, não apenas do microssistema, considerando-se os princípios da ampla defesa e da economia processual e resolvendo, num único processo e por meio de uma única instrução probatória, duas demandas. É certo, ademais, que todos têm direito a uma demanda célere, diante do princípio da duração razoável do processo (art. 5\%, LXXVIII, da CF), mas não apenas o consumidor, de modo que não é cabível afastar genericamente a denunciação da lide, conferindo-lhe proteção desproporcional.

\footnotetext{
${ }^{269}$ José Luiz Ragazzi sustenta não ser cabível a denunciação da lide, a fim de "não contrariar os princípios norteadores da responsabilidade objetiva adotada pelo Código e, ainda, os princípios que informam o microssistema, tais como o da vulnerabilidade, facilitação da defesa e acesso à justiça". Defende a impossibilidade da denunciação da lide, "exceto se a mesma vier a beneficiar a efetiva tutela jurisdicional do consumidor", considerando "salutar" permitir a denunciação da lide, exemplificativamente, se o produtor demandado pelo consumidor for insolvente, "visando à efetiva indenização do consumidor" (Intervenção de terceiros e o código de defesa do consumidor, p. 136-137).

${ }^{270}$ Luiz Antônio Rizzatto Nunes critica a norma do art. 88 do CDC, classificando-a de "incompleta". Embora não trate da vedação da denunciação da lide de maneira genérica, destaca que o art. 88 é "regra adjetiva" para proibir a denunciação da lide, que remete ao parágrafo único, do art. 13, de modo que, "se a regra pretende evitar o prolongamento do processo com ações paralelas, tem de proibir tanto a denunciação à lide quanto o chamamento ao processo" (Comentários ao código de defesa do consumidor, p. 203).
} 
5.7.2. Da hipótese do art. 101, II, do CDC. O art. 101, II, do Código de Defesa do Consumidor estabelece que, na ação de responsabilidade civil do fornecedor de produtos e serviços, "o réu que houver contratado seguro de responsabilidade poderá chamar ao processo o segurador, vedada a integração do contraditório pelo Instituto de Resseguros do Brasil. Nesta hipótese, a sentença que julgar procedente o pedido condenará o réu nos termos do art. 80 do Código de Processo Civil. Se o réu houver sido declarado falido, o síndico será intimado a informar a existência de seguro de responsabilidade, facultando-se, em caso afirmativo, o ajuizamento de ação de indenização diretamente contra o segurador, vedada a denunciação da lide ao Instituto de Resseguros do Brasil e dispensado o litisconsórcio obrigatório com este".

Esse dispositivo, independentemente de sua redação, deve ser analisado, a fim de se precisar qual é a modalidade de intervenção de terceiro por meio da qual o réu poderá “chamar" o segurador ao processo.

Pela interpretação literal do texto legal, transparece que o segurador poderá intervir na demanda, por força do chamamento ao processo. O dispositivo utiliza-se da expressão “chamar ao processo" e refere-se ao art. 80 do Código de Ritos, que regula o chamamento ao processo.

Ocorre, todavia, que o chamamento ao processo do segurador, no caso de o réu ter firmado com ele contrato civil de responsabilidade civil, não se ajusta às hipóteses do art. 77 do texto processual. Não se trata de fiança e falta vínculo jurídico entre o consumidor e o segurador, tanto que somente o segurado, que é o fornecedor, tem legitimidade para poder chamar ao processo. Assim, o segurado e o segurador não podem ser considerados devedores solidários, diante da ausência de relação jurídica de direito material entre este e o consumidor e da limitação de sua responsabilidade quanto ao valor da apólice, o que contraria o disposto no art. 264 do Código Civil. Tecnicamente, não se trata de chamamento ao processo, mas de direito de regresso do segurado em relação ao segurador, de modo que a situação se ajusta, respeitados os seus contornos, à denunciação da $\operatorname{lide}^{271}$.

\footnotetext{
${ }^{271}$ José Luiz Ragazzi diz que o Código de Defesa do Consumidor criou um “instituto híbrido”, dado que fez "emergir uma obrigação direta deste ante ao consumidor, apesar de não haver entre consumidor e segurador qualquer relação jurídica contratual, gerando uma solidariedade entre fornecedor e segurador perante o consumidor". Conclui que "o caso é típico de denunciação da lide", porém a intenção do legislador, ao
} 
Apesar disso, não é possível considerar que se trata do instituto da denunciação ${ }^{272}$, de vez que, além de ser incompatível com o sistema do Código de Defesa do Consumidor, o legislador tratou a hipótese como chamamento ao processo - invocando, inclusive, a regra do art. 80 do texto processual - bem como vedou expressamente a denunciação. Cuida-se, então, de um chamamento ao processo atípico, em que se pretendeu proteger e dar maior garantia ao consumidor. Isso ocorre ao se conferir ao réu a possibilidade de chamar ao processo o segurador, que poderá ser condenado a pagar diretamente ao consumidor a indenização nos limites da apólice ${ }^{273}$.

Essa previsão legal possui nítida conotação protecionista, por estar fundada na ideia de que, em tese, o segurador tem melhores condições econômicas para satisfazer a obrigação a que o consumidor tem direito. Buscou-se beneficiá-lo, evitando-se os percalços de se ter que executar o segurado, muitas vezes insolvente, garantindo a indenização nos limites do contrato. Diante do chamamento, ambos podem ser condenados solidariamente, buscando eliminar as dificuldades de a obrigação ser satisfeita; é de rigor, porém, resguardar a posição do segurado. Este poderá, se satisfizer a dívida, exigir o montante pago do segurador no limite do valor da apólice, já que a sentença valerá como título executivo judicial diante da regra do art. 80 do Código de Processo Civil ${ }^{274}$.

permitir o chamamento, é "tornar possível o acesso do consumidor a um processo célere e efetivo" (Intervenção de terceiros e o código de defesa do consumidor, p. 147-149).

${ }^{272}$ Em sentido contrário, Eduardo Henrique de Oliveira Yoshikawa, em interessante artigo, critica a redação deficiente do art. 101, II, do CDC, afasta a possibilidade de se considerar que se trata de chamamento ao processo e conclui que, nas ações de responsabilidade por danos causados aos consumidores, autorizou-se a denunciação da lide. Apesar de concordarmos não se tratar propriamente de chamamento ao processo, entendemos não ser possível aceitar que a modalidade de intervenção de terceiro é a denunciação da lide, por a previsão legal estabelecer, expressamente, a possibilidade de o consumidor executar diretamente o segurador, nos termos do art. 80 do CPC (Cabimento da denunciação da lide ao segurador nas ações de reparação de dano com fundamento no Código de defesa do consumidor (o falso chamamento ao processo do artigo 101 do $(D C)$, p. 09-14).

${ }^{273}$ Kazuo Watanabe expõe que o art.101 do CDC amplia o elenco do art. 77 do CPC, ficando "abrangido o segurador do fornecedor de produtos e serviços, que passa a assumir a condição de co-devedor perante o consumidor". Concluiu que o chamamento ao processo "amplia a garantia do consumidor e ao mesmo tempo possibilita ao fornecedor convocar desde logo, sem a necessidade de ação regressiva autônoma, o segurador para responder pela cobertura securitária prometida" Código brasileiro de defesa do consumidor comentado pelos autores do anteprojeto, p. 798). Gustavo de Medeiros Melo diz que se trata de "uma espécie de chamamento ao processo", que "se deve a uma vontade política do direito material" (A ação direta do terceiro prejudicado no seguro de responsabilidade civil, p. 289-295).

${ }^{274}$ Nesse sentido, corretas são as considerações de Sergio Cavalieri Filho, ao afirmar que "o Código de Defesa do Consumidor inovou propositadamente na matéria, criando entre segurado e segurador uma solidariedade legal em favor do consumidor. A inovação tem por consequência processual, conforme previsto no mesmo dispositivo, que a sentença, ao julgar procedente o pedido, condenará a ambos nos termos do art. 80 do Código de Processo Civil, vale dizer, o decisum constituirá título executivo em favor do consumidor tanto contra o segurado como contra o segurador" (Programa de responsabilidade civil, p. 472). 
$\mathrm{O}$ art. 101, II, do Código de Defesa do Consumidor autoriza, outrossim, que a vítima que sofreu o dano ajuize ação diretamente contra o segurador, se o réu for declarado falido. Estabelece-se, portanto, uma solidariedade legal entre segurado e segurador, tanto que se admite o chamamento ao processo. De qualquer maneira, não cabe ao segurador denunciar a lide ao IRB - Brasil Resseguros Sociedade Anônima. Prestigia-se o consumidor, a fim de a ação regressiva não prejudicar a demanda principal, pois não existe qualquer vínculo entre o consumidor e o potencial denunciado; tal operação sequer envolve o segurado, mas apenas uma companhia de seguros e outra de resseguros. Assim, o objeto da lide regressiva não tem qualquer liame com o da principal.

Acrescente-se, ainda, que o segurador poderá ser eventualmente responsabilizado a pagar indenização, mas nunca a resseguradora. Dessa forma, diante de todas essas particularidades associadas ao contrato de resseguro, consideramos correta a vedação da denunciação da lide ao IRB - Brasil Resseguros Sociedade Anônima nas ações de indenização envolvendo relação de consumo, assegurando-se, de qualquer maneira, ao segurador, o direito de agir regressivamente em ação autônoma.

5.8. Da ação rescisória. Como a sentença produz efeitos apenas para as partes entre as quais é dada, não beneficiando nem prejudicando terceiros (art. 472 do CPC), torna-se interessante o estudo da ação rescisória, associada ao instituto da denunciação da lide, por diversas perspectivas.

Com efeito, a sentença de mérito, transitada em julgado, pode ser rescindida, nas hipóteses do art. 485 do Código de Processo Civil. Tem legitimidade ativa para propô-la quem foi parte no processo ${ }^{275}$ ou o seu sucessor a título universal ou singular, o terceiro juridicamente interessado ou o Ministério Público (art. 487 do CPC).

275 Alexandre Freitas Câmara diz que "todos aqueles que tenham participado no processo original, e tiveram influência no resultado, têm legitimidade ativa para a ação rescisória” (Ação rescisória, p. 126). 
Por primeiro, o denunciado do processo principal não pode ser confundido com "o terceiro juridicamente interessado" 276 , a que se refere o art. 487, II, do Código de Processo Civil. Na realidade, para a ação rescisória, aquele que figurou como denunciado no feito originário possui interesse jurídico, mas não é propriamente terceiro, dado que foi réu na lide secundária, cuja sentença pretende rescindir. Como a decisão rescindenda pode ser desconstituída ou novamente julgada, afetando eventualmente os interesses do denunciado definidos na sentença, ele tem inegável legitimidade ativa para propor ação rescisória, na condição de parte (art. 487, I, do CPC). Deve-se, nesse sentido, conferir interpretação ampla para a expressão "parte no processo", englobando tanto a ação principal como a lide secundária, não sendo possível restringir a legitimidade apenas aos que eram os litigantes da ação originária.

Como existe uma única sentença que decidiu a ação e a denunciação da lide, o denunciante e o denunciado daquele feito podem pretender rescindir tanto a lide secundária, na qual figuraram como parte, quanto a própria ação principal, em vista dos reflexos que ela causa e de o denunciado ter o ônus de auxiliar o denunciante ${ }^{277}$. Para aqueles que consideram que o denunciado é litisconsorte do denunciante ou que admitem a condenação direta daquele, fica ainda mais clara sua legitimidade para ajuizar a rescisória. Desse modo, não há dúvida de que ao denunciado é facultado ajuizá-la.

De outro lado, não é possível ao adversário do denunciante na ação principal postular a desconstituição da lide secundária, por ela não atingir seus interesses ${ }^{278}$, a não ser que se admita a condenação direta. A situação é, pois, distinta da do denunciante e da do denunciado, em razão de os interesses deles serem atingidos por eventual procedência da ação rescisória.

\footnotetext{
${ }^{276}$ Nesse sentido, Flávio Luiz Yarshell considera, ao tratar da assistência - porém a mesma conclusão pode por analogia ser utilizada para a denunciação da lide - ser mais correto permitir que o assistente está legitimado a pleitear a desconstituição do julgamento do mérito por ação rescisória como "parte", porém não descarta permitir que a sua intervenção se dê como "terceiro juridicamente interessado" (Ação rescisória: juízos rescindente e rescisório, p. 314).

${ }^{277}$ V. Maria Berenice Dias, que, ao considerar que o denunciado assume a posição de assistente simples na lide secundária, diz que ele "pode fazer uso da ação rescisória, tanto para atacar a ação incidente da qual participou na qualidade de réu, como também para buscar desconstituir a ação principal" (O terceiro no processo, p. 146).

${ }^{278}$ Sydney Sanches, Denunciação da lide no direito processual civil brasileiro, p. 246.
} 
Questão intrincada é relativa à legitimidade passiva para a ação rescisória, especialmente diante da ausência de dispositivo legal a respeito. Haveria necessidade de integrar à lide todos os que eram partes no processo, cuja sentença se pretende rescindir? Num primeiro momento, diante das finalidades da ação rescisória, de desconstituição da sentença de mérito transitada em julgado ou de rejulgamento da causa, parece-nos que aqueles que foram atingidos pela sentença devem figurar no polo ativo ou passivo, pois seus interesses poderão ser diretamente afetados ${ }^{279}$.

Ocorre, todavia, que pode ocorrer de a sentença rescindenda ser complexa, por possuir diversos capítulos, e o pedido do denunciado ser restrito apenas ao capítulo que reconheceu o direito de regresso do denunciante em face dele. Nesse caso, não existe propriamente necessidade efetiva de o adversário do denunciante da ação originária ser citado para a ação rescisória ${ }^{280}$, mas recomenda-se, ainda assim, que ele tenha, ao menos, ciência da ação ${ }^{281}$.

Diferente é a situação em que o autor ou o réu da ação originária propõe a ação rescisória, pois haverá necessidade de o denunciado ser citado para integrá-la, de vez que, ainda que o pedido se reporte apenas a capítulo da ação principal, haverá reflexos que poderão atingi-lo. Além disso, o denunciado deve, ao menos, ser citado para poder auxiliar na defesa daquele que denunciou a lide no processo originário.

Por derradeiro, é necessário abordar se é possível requerer, na ação rescisória, a denunciação da lide, nas hipóteses em que não houve intervenção de terceiro na ação originária, embora ela fosse, inclusive, cabível. Parece-nos não ser possível, por falta de legitimidade e de interesse do denunciado, pois ele não possui vínculo com a ação principal e não pode postular a rescisão da sentença, que não tem o condão de atingi-lo $(\text { art. } 472 \text { do CPC) })^{282}$.

${ }^{279}$ Cf. Américo Andrade Pinho, A legitimidade do terceiro interessado para a ação rescisória, p. 67; Maria Berenice Dias, $O$ terceiro no processo, p. 138.

${ }^{280}$ STJ, Ag 1.308.611, Rel. Min. TEORI ALBINO ZAVASCHI, DJ. 08.08.2012. Em idêntico sentido, José Carlos Barbosa Moreira, Comentários ao código de processo civil, p. 175.

${ }^{281}$ Nessa linha, José Manoel de Arruda Alvim Netto, Araken de Assis e Eduardo Arruda Alvim dizem "que devem ser citados para a ação rescisória todos aqueles que eram partes no processo cuja sentença se pretende rescindir. Com efeito, se há possibilidade da decisão ser rescindida, todos aqueles que forem atingidos por essa decisão, deverão ao menos ter ciência da propositura da ação" (Comentários ao código de processo civil, p. 777).

${ }_{282}$ Maria Berenice Dias afirma, ao se reportar ao que poderia ter sido denunciado e não o foi, que "não se estabelecendo a lide incidente (na qual figuraria na condição de réu), seu vínculo com a demanda principal 


\section{DAS REGRAS PROCEDIMENTAIS PARA A DENUNCIAÇÃO DA LIDE}

\subsection{Da competência para processar e julgar a denunciação da lide. $\mathrm{O}$ art. 109}

do Código de Processo Civil prevê, expressamente, que “o juiz da causa principal é também competente para a reconvenção, a ação declaratória incidente, as ações de garantia e outras que respeitam ao terceiro interveniente". A regra, em princípio, parece elementar na medida em que a denunciação desenvolve-se nos mesmos autos da demanda principal. A questão, todavia, não é tão simples.

O legislador refere-se à "causa principal" e às "ações de garantia e outras que respeitam ao terceiro interveniente", de modo que é evidente que se aplica o artigo à denunciação da lide, por se tratar de lide secundária. Ao reportar-se à ação principal, trata, ademais, de hipóteses que não são a causa principal, como sucede com a reconvenção e a ação declaratória incidente. Inclui, ainda, as ações de garantia e demais causas que envolvam terceiros, de forma que a denunciação da lide está, claramente, abrangida.

Assim, a denunciação da lide segue a mesma competência da ação principal, tornando indiferentes os motivos que definiriam a competência da ação de garantia, caso essa fosse proposta isoladamente. Desse modo, o réu da ação de garantia (denunciado), que poderia ser demandado no seu domicílio, perde esse direito, tendo que se render à previsão do art. 109 e responder no mesmo juízo.

Essa regra, entretanto, não supera os princípios atinentes à competência absoluta, em vista de ser esta estabelecida em função do interesse público e de ser inderrogável pela

(que lhe daria legitimação para ingressar como mero assistente) não se mostra com suficiência para o uso da ação de rescisão" (O terceiro no processo, p. 147). Nesse mesmo sentido, aponta-se para a posição de Alexandre Freitas Câmara, que, todavia, faz pertinente ressalva, ao dizer não ser possível a denunciação da lide na ação rescisória, "em razão do eventual rejulgamento da causa original, embora possa vir a ser possível, nos casos em que não incumba ao tribunal o juízo rescisório, que se retorne o processo original a um ponto em que tal intervenção ainda pudesse ser provocada" (Ação rescisória, p. 137). 
vontade das partes, tanto que, se não for declarada de ofício, pode ser alegada por qualquer interessado, inclusive pelo denunciado, a qualquer tempo e em qualquer grau de jurisdição, independentemente de exceção (art. 113 do CPC). As questões relativas à competência funcional e material não são, portanto, suplantadas pelo art. 109.

Quando a ação principal tramita perante a Justiça Estadual e a União Federal é denunciada, consideramos não ser cabível a denunciação da lide, dado que não se deve conferir ao art. 109 do texto processual a simples conotação de regra de competência, mas sim a um pressuposto para a denunciação ${ }^{283}$. Destarte, a ação de regresso, quando exercitada pela via da denunciação, supõe que não esteja sujeita à regra de competência de natureza absoluta diferente daquela da ação principal, pois, se tanto for, ela não terá lugar e o direito de regresso deverá ser exercido por ação autônoma posteriormente.

A questão não deve ser enfrentada singelamente a partir da súmula 150 do Superior Tribunal de Justiça, em vista de não se discutir sobre existência de interesse jurídico da União Federal. Trata-se de um pressuposto para a denunciação, que, por não ter sido preenchido, a torna infundada.

Pondere-se que, caso assim não se entenda, não caberá, de qualquer modo, ao juízo estadual apreciar o cabimento da denunciação da lide, mas apenas ao juízo federal ${ }^{284}$. Isso se dá, em razão de haver interesse de ente federal, aplicando-se, então, a súmula 150 do Superior Tribunal de Justiça, porque a Justiça Federal é a competente para decidir sobre a existência de interesse jurídico que justifique a presença da União, suas autarquias ou empresas públicas, no processo.

Na hipótese da inviabilidade de processar-se a ação de regresso no mesmo juízo, não se pode restringir futura ação autônoma, ainda que seja caso de denunciação obrigatória. Se não for assim, a própria regra processual limita o direito do denunciante, o que é um contrassenso - do mesmo modo que ponderamos quanto à limitação da

\footnotetext{
${ }^{283}$ Sydney Sanches também não admite a denunciação da lide à União Federal. Sustenta que "a Justiça do Estado não teria competência para examinar a ação incidental, pois não há prorrogação a esse ponto. Por outro lado, à Justiça Federal não competiria o exame da causa principal (art. 125 da CF)" (Denunciação da lide, p. 176).

${ }^{284}$ Cf. STJ, REsp 1.003.635/MG, Rel. Min. JOSÉ DELGADO, $1^{\text {a }}$ Turma, J. 08/04/2008; e CC 21.792/RR, Rel. Min. HUMBERTO GOMES DE BARROS, $1^{\text {a }}$ Seção, J. 26/08/1998.
} 
intervenção no procedimento sumário e nos Juizados Especiais, bem como nas hipóteses em que a citação não é feita no prazo legal por circunstância não atribuída ao denunciante.

O mesmo sucede em relação à intervenção da Fazenda Estadual ou Municipal, que importa no deslocamento da competência, no caso de haver varas especializadas no âmbito da Justiça dos Estados. Em Comarcas em que não há juízos especializados, no entanto, a denunciação segue o curso normal.

Ressalve-se, ainda, que, se o réu aceita o foro em que a ação foi proposta, haverá preclusão e prorrogação da competência, de modo que, se não for incompetência absoluta, não cabe ao denunciado arguir exceção de incompetência. Nesse caso, a lide secundária não influirá na definição da competência ${ }^{285}$.

6.2. Do requerimento da denunciação da lide. A denunciação da lide constitui modalidade de intervenção de terceiro que pode ser requerida tanto pelo autor como pelo réu. $\mathrm{O}$ autor, se for o caso, deverá, na petição inicial, pleitear a citação do denunciado, juntamente com a do réu, ao passo que, se o denunciante for o réu, deverá fazê-lo no prazo para contestar (art. 71 do CPC) $)^{286}$.

Apesar de transparecer incongruente, o réu poderá denunciar eventualmente até mesmo seu próprio litisconsorte, em razão de haver uma relação jurídica distinta da mantida pelo autor com o corréu, a fim de assegurar sua pretensão regressiva, que lhe confere interesse jurídico ${ }^{287}$. Na hipótese, por exemplo, de o autor mover a ação em face de dois réus (patrão e empregado, por exemplo), embora a culpa direta pelo dano, em um

\footnotetext{
${ }^{285}$ Paulo Palmeira diz, ao tratar do direito italiano, que na "chiamata in garanzia o garante tem a faculdade de alegar a incompetência do juiz, quando a ação tenha sido proposta perante juiz incompetente, mesmo territorialmente, uma vez que pelo Código vigente a demanda de garantia deve ser proposta perante o juiz competente para a causa principal e não, como se dizia no Código anterior, perante o juiz da causa principal, simplesmente" (Da intervenção de terceiros nos principais sistemas legislativos: da oposição, p. 43). Existe, pois, uma perspectiva diferente quanto à competência, que não se aplica no direito brasileiro.

${ }^{286}$ Nesse sentido, a jurisprudência do Superior Tribunal de Justiça é reiterada: REsp 866.119/RS, Rel. Min. TEORI ALBINO ZAVASCKI, $1^{\text {a }}$ Turma, J 17/05/2011.

${ }^{287}$ Cf. Cândido Rangel Dinamarco, Instituições de direito processual civil, v. II, n. 64, p. 405-406; e Vicente Greco Filho, Da intervenção de terceiros, p. 94. Nesse sentido, tem decidido, reiteradamente, o Tribunal de Justiça de São Paulo: AI 0045275-89.2011.8.26.0000, Rel. Des. SÁ MOREIRA DE OLIVEIRA, $33^{\mathrm{a}}$ Câmara de Direito Privado, J. 08/08/2011; AI 0012020-14.2009.8.26.0000, Rel. Des. MELO COLOMBI, $14^{a}$ Câmara de Direito Privado, J. 19/08/2009; AI 9024563-42.1999.8.26.0000; Rel. Des. ANTONIO CARLOS MARCATO, 6ª Câmara de Direito Privado, J. 01/07/1999.
} 
acidente de veículo, seja de apenas um deles, é plenamente cabível o réu, não se julgando culpado, denunciar aquele que ele entende ter culpa. Se deferida a denunciação e o réu denunciante for condenado e pagar o débito, ele terá como ser ressarcido, caso a lide secundária seja julgada procedente.

Em todas as hipóteses elencadas no art. 70 do Código de Processo Civil, passarão a existir duas relações jurídicas processuais, envolvendo o autor e o réu numa delas e o denunciante e o denunciado na outra. Seja a denunciação da lide feita pelo autor ou pelo réu, caberá ao juiz apreciar o pedido e deferi-lo ou não. Se for reconhecido o cabimento da denunciação, o denunciado será citado. Se indeferido, o denunciante poderá interpor agravo de instrumento.

Como a denunciação da lide pode ser requerida tanto pelo autor como pelo réu, o que constitui característica distinta em relação às demais modalidades de intervenção de terceiros, e tendo em vista as particularidades da denunciação da lide feita pelo autor e pelo réu, delas trataremos separadamente.

O autor, se pretender denunciar a lide, deverá fazê-lo na própria petição inicial. Nesse caso, a citação do denunciado deverá ser feita antes que a do réu, pois o terceiro poderá, ao comparecer, apresentar defesa e, ainda, aditar a petição inicial (art. 74 do $\mathrm{CPC})^{288}$. Nesse caso, a lide deixará de ter o perfil inicial que o autor lhe conferiu ${ }^{289}$.

A lei não prevê o prazo para o denunciado contestar a ação. De qualquer maneira, impõe-se estabelecer, até mesmo por analogia e para não conferir privilégio, o mesmo

\footnotetext{
${ }^{288}$ Celso Agrícola Barbi critica a possibilidade de o denunciado aditar a petição inicial, em vista de o autor ser o dominus litis (Comentários ao Código de Processo Civil, n. 418, p. 136), o que, num primeiro momento, considera-se correto, mas deve ser temperado. Na realidade, se o autor não quisesse que o denunciado interviesse, bastava não ter pleiteado a denunciação, podendo, nas hipóteses de ela ser facultativa, ajuizar futura ação de regresso autônoma. Além disso, a atuação do terceiro, denunciado pelo próprio autor, tem forte característica de assistência, dado seu efetivo interesse na procedência da ação para evitar, no caso de o autor sucumbir, que a lide secundária seja julgada procedente.

${ }^{289}$ Athos Gusmão Carneiro, ao tratar do aditamento da petição inicial, ressalta que "pode assistir interesse ao denunciado em reforçar a posição do demandante, de modo a tornar mais viável a procedência da ação principal, assim resguardando, ele, denunciado, seu próprio interesse em que não surja a pretensão regressiva". Diz, ainda, que o denunciado pode acrescentar, "já agora como 'litisconsorte' do autor, uma nova causa petendi, ou em trazer mais elementos e argumentos de fato ou de direito à petição inicial, ou quiçá em expungi-la de irregularidades que poderiam torná-la inepta". Pondera, no entanto, que não pode "alterar substancialmente o próprio pedido formulado pelo denunciante" ou cumular outros pedidos, até mesmo porque não teria interesse, em vista de eventual direito de regresso não poder ultrapassar o próprio pedido (Intervenção de terceiros, n. 49, p. 136).
} 
prazo legal que o réu possui, respeitando-se os procedimentos. Assim, no rito ordinário, inexiste qualquer dificuldade, apesar da falta de norma expressa para essa situação processual, para definir-se que o prazo é de quinze dias (art. 297 do CPC).

No procedimento sumário, dispõe o Código que a defesa deve ser apresentada na própria audiência de conciliação (art. 278 do CPC), que, no entanto, diante do quadro instaurado com a denunciação pelo autor, não tem sentido de ser designada, dado que seria inútil realizá-la apenas com o autor e o denunciado. O procedimento deve, pois, ser adaptado, notadamente porque a admissão da denunciação nesse rito é excepcional.

Diante da falta desse ato processual, dos contornos do procedimento e do limite temporal mínimo legalmente previsto, deve-se estabelecer o prazo de dez dias, por ser essa a antecedência mínima em relação à audiência que o réu deve ser citado (art. 277, caput, do CPC). Torna-se, portanto, desnecessária a designação de audiência de conciliação, mesmo porque, ordenada a citação do denunciado, o processo principal ficará suspenso até sua manifestação, que não se sabe quanto tempo demorará, desconhecendo-se, outrossim, a postura que ele adotará.

Assim sendo, deve-se, inicialmente, apenas determinar a citação do denunciado, concedendo-lhe prazo de dez dias no procedimento sumário, por analogia ao intervalo mínimo que se há de respeitar até a audiência de conciliação, a fim de possibilitar que ele adite a petição inicial para somente após designar a audiência e ordenar a citação do réu (art. 74 do CPC). Se assim não for, é capaz de não haver tempo hábil, antes da audiência designada, para o denunciado ser citado, apresentar sua contestação na lide secundária e, se for o caso, aditar a inicial, sendo preferível adaptar o procedimento, conferindo-lhe tratamento excepcional.

No caso de a Fazenda Pública ser denunciada, o prazo para eventual aditamento da inicial e contestação, por coerência, deve ser computado em quádruplo (art. 188 do CPC). Se forem dois ou mais denunciados, representados por diferentes procuradores, o prazo deverá ser contado em dobro (art. 191 do CPC).

Só depois disso, o réu deverá ser citado. 
A questão tem outro contorno na hipótese de o denunciante ser o réu. Nesse caso, há controvérsia sobre qual momento o processo será suspenso e se o réu denunciante deverá, ao requerer a denunciação, também apresentar contestação ou se, após a citação do denunciado, o prazo lhe será reaberto.

Pondere-se, inicialmente, que não existe a imposição de o réu apresentar contestação e pleitear a denunciação da lide simultaneamente, na mesma petição ${ }^{290}$. Se o fizer conjuntamente, a contestação deverá ser tempestiva e a denunciação, feita no prazo para contestar $^{291}$. Isso poderá ser realizado na própria contestação ou em petições distintas e em diferentes momentos, desde que naquele prazo para contestar ${ }^{292}$.

Consideramos que a suspensão do processo principal só se dará após ser proferida decisão judicial que determine a citação do denunciado, como fica claro a partir da interpretação literal do art. 72 do Código de Processo Civil, que estabelece: "ordenada a citação, ficará suspenso o processo". Dessa maneira, a simples oferta de denunciação da lide não acarreta a suspensão automática do processo, de modo que o prazo para contestar continua a fluir ${ }^{293}$.

Se, por outro lado, o despacho que deferir a denunciação e ordenar a citação for anterior ao termo final para contestar, o prazo para contestação será suspenso. No entanto, caso o juiz não aprecie o pedido de intervenção de terceiro antes de escoar esse prazo legal para defesa ou se o mesmo for indeferido, o prazo para contestar não terá sido suspenso e

\footnotetext{
${ }^{290}$ Athos Gusmão Carneiro assevera que "a denunciação da lide deve ser oferecida em petição própria, com os requisitos do art. 282 do Código de Processo Civil", porém reconhece que não haverá maior inconveniente "em que seja redigida na mesma peça da petição inicial (na denunciação pelo autor) ou da contestação (na denunciação pelo réu)", desde que se obedeça os requisitos e que formalmente se destaque a denunciação (Intervenção de terceiros, n. 50-A, p. 138).

${ }^{291}$ Se a contestação for intempestiva, o pedido de denunciação é extemporâneo e não pode ser conhecido (cf. TJSP, AP 0032329-16.2010.8.26.0002, Rel. Des. CESAR CIAMPOLINI, J. 03/07/2012).

292 "O art. 71 do Código de Processo Civil prevê que o réu pode requerê-la no prazo para contestar e não junto com a contestação ou na própria contestação", até porque são "atos processuais independentes: uma coisa é contestar a ação; outra, denunciar terceiro à lide" (extinto $2^{\circ}$ TAC/SP, AI 900585014.2002.8.26.0000, $5^{a}$ Câmara, Rel. Des. DYRCEU CINTRA, J. 28/05/2003). Em sentido contrário, Milton Flaks sustenta estar precluso o direito de o réu denunciar a lide, caso já tenha apresentado sua contestação, ainda que não tenha esgotado o prazo legal, pois "presume-se que, se antecipou a contestação, renunciou ao prazo restante (CPC, art. 186)" (Denunciação da lide, p. 222).

${ }^{293}$ Cf. Cássio Scarpinella Bueno, Partes e terceiros no processo civil brasileiro, p. 232; Sydney Sanches, Denunciação da lide no direito processual civil brasileiro, p. 166.
} 
não será restituído ${ }^{294}$, de modo que o réu deverá ter redobrada atenção para não ser surpreendido pela preclusão temporal e tornar-se revel.

Assim, o simples pedido de denunciação da lide não tem o condão de suspender o processo, havendo, no entanto, corrente em sentido contrário ${ }^{295}$. Consideramos não ser aplicável sequer por analogia a regra do art. 67 do Código de Processo Civil, que trata de maneira específica da nomeação à autoria, conferindo novo prazo para o réu contestar a ação, na hipótese de ele recusar o nomeado ou de o nomeado negar a qualidade que lhe é atribuída. O que justifica a nomeação é o próprio distanciamento do nomeante das questões que terão que ser enfrentadas naquele processo.

Não é possível conferir interpretação ampliativa ao dispositivo, voltado apenas para a referida modalidade de intervenção de terceiros. Na nomeação, o réu, caso não ocorra sua substituição, permanecerá no polo passivo e novo prazo para defesa lhe será concedido, por haver expressa disposição legal nesse sentido. A situação do denunciante, entretanto, é bem diversa, dado que ele permanecerá no polo passivo da demanda, independentemente de ser ou não deferida a intervenção de terceiro; assim sendo, não é razoável conceder-lhe novo prazo.

Pondere-se que o processo poderá, antes da denunciação, ser declarado suspenso, por outros motivos, como exceção de suspeição, de impedimento do juiz ou de incompetência do juízo, deduzidas antes da contestação (arts. 265, III, e 306 do CPC), hipóteses em que o prazo para o requerido contestar e denunciar a lide, por consequência, também ficará suspenso.

Da mesma forma se passa com as hipóteses de suspensão "durante as férias e feriados" (art. 173 do CPC), bem como "pela morte ou perda da capacidade processual de qualquer das partes, de seu representante legal ou procurador" (art. 265, I, do CPC).

\footnotetext{
${ }^{294}$ O Tribunal de Justiça de São Paulo tem decidido não ser cabível a reabertura de prazo para contestar: AP 9168071-36.2005.8.26.0000, 28 $8^{\text {a }}$ Câmara de Direito Privado, Rel. Des. EDUARDO SÁ PINTO SANDEVILLE, J. 01/03/2011; AI 0296399-98.2009.8.26.0000, 32 ${ }^{\mathrm{a}}$ Câmara de Direito Privado, Rel. Des. WALTER ZENI, J. 18/03/2010; AI 0040568-54.2006.8.26.0000, 35ª Câmara de Direito Privado, Rel. Des. CLÓVIS CASTELO, J. 23/10/2006.

${ }^{295}$ Assim, Daniel Amorim Assumpção Neves sustenta "que a interrupção do prazo para defesa deveria ser computada desde o pedido do réu, e não do deferimento do juiz", por considerar que a expectativa do réu em ser aceita sua denunciação é "suficiente para suspender o prazo de defesa, evitando assim indesejáveis e injustas consequências" (Intervenção de terceiros e revelia, p. 31).
} 
No procedimento ordinário, se a contestação já tiver sido apresentada, a denunciação da lide pode ser feita, em tese, desde que ainda esteja "no prazo para contestar", de acordo com o art. 71 do Código de Processo Civil, em razão de se privilegiar a finalidade do instituto. Não há qualquer previsão legal de que a contestação e a denunciação da lide devam ser apresentadas simultaneamente, como sucede com a contestação e a reconvenção (art. 299 do CPC). Ressalve-se, no entanto, que nenhum ato processual incompatível ou que tenha dado prosseguimento à demanda pode ter sido praticado na sequência, antes de terminar o prazo para contestar, dado que, do contrário, o pedido de intervenção de terceiro ficará prejudicado ${ }^{296}$.

A situação é tratada diversamente no direito português, estabelecendo o art. 331 do Código de Processo Civil português que "o chamamento é deduzido pelo réu na contestação ou, não pretendendo contestar, no prazo em que esta deveria ser apresentada", de modo que, deduzida a contestação, preclui o direito de o requerido pleitear a denunciação da lide. Já no modelo do primitivo direito alemão, a denunciação da lide, por apresentar somente conotação de assistência, é permitida em qualquer fase do litígio, o que, todavia, não é cabível no sistema brasileiro vigente.

No rito sumário, no qual se tornou possível a denunciação fundada em contrato de seguro - por força da alteração do art. 280 do Código de Processo Civil, em vista da redação conferida pela Lei 10.444/2002 - o réu deverá, da mesma maneira, denunciar a lide "no prazo para contestar", ou seja, poderá fazê-lo, se frustrada a conciliação, na própria audiência, ao apresentar sua defesa (art. 278 do CPC). Nada impede, porém, que ele se antecipe à audiência e realize a denunciação antes da realização do ato designado, hipótese em que poderá ser colhido melhor proveito daquela que, do contrário, fatalmente terá que ser redesignada.

Determinada a citação do denunciado, o processo ficará suspenso até ela efetivarse, podendo o juiz designar, desde logo, se o caso, audiência de instrução e julgamento,

\footnotetext{
${ }^{296}$ O Superior Tribunal de Justiça já considerou precluso o direito de denunciação da lide, em demanda na qual o réu apresentou contestação antes de escoado integralmente o prazo legal de contestação, por já ter sido praticado, na sequência, outro ato processual. Considerou-se que a interpretação do art. 71 do CPC não "comporta elasticidade tão ampla para se acatar a denunciação quando o julgador já tenha dado prosseguimento à marcha processual após a apresentação apressada da contestação" (REsp 1.099.439/RS,

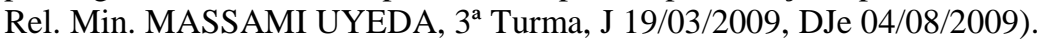


com intervalo de tempo suficiente para citar, a fim de evitar o retardamento da prestação da tutela jurisdicional $^{297}$. Não há como impor que o réu faça a denunciação antes da audiência designada, a fim de o denunciado já estar citado e participar dela, dado não existir norma expressa nesse sentido e não ser razoável reduzir esse prazo em seu prejuízo.

O prazo do denunciado para contestar a lide regressiva será, no rito sumário, na própria segunda audiência de conciliação a ser designada ${ }^{298}$, por coerência com o disposto no art. 278 do Código de Processo Civil.

Não existe óbice, outrossim, para o denunciado - além de aditar a inicial ou de contestar, a depender de ter sido feita a denunciação pelo autor ou pelo réu - apresentar reconvenção contra o denunciante, no caso de esta ser conexa com a lide secundária ou com o fundamento de defesa (art. 315 do CPC). Esses pressupostos devem identificar-se com a denunciação da lide, mas não com a ação principal, até porque nesta o terceiro não está na posição de réu e apenas invoca direito próprio em relação ao denunciante. Por força disso, não cabe reconvenção do denunciado em face do adversário do denunciante ${ }^{299}$.

\subsection{Dos atos e posturas do denunciante que repercutem na denunciação. Não} se coloca como necessária a apresentação de contestação discutindo o mérito para que o réu possa denunciar a lide a terceiro. Qualquer atitude e ato, em princípio, não elimina o

\footnotetext{
${ }^{297}$ Nesse sentido, José Rogério Cruz e Tucci entende que "quando deduzida pelo réu, deve ser suspensa a audiência de conciliação (art. 278), e o denunciado será citado para, na continuação do referido ato processual, oferecer a sua resposta, acompanhada de documentos, rol de testemunhas e requerimento de perícia, se houver. Nada obsta, porém, que havendo necessidade de ser realizada a audiência de instrução e julgamento, o juiz a designe, desde logo, concedendo ao denunciado prazo suficiente para apresentar seu requerimento de prova oral, acompanhado do rol de testemunhas, ou, ainda, para que requeira prova pericial, formulando quesitos e indicando assistente técnico" (Lineamentos da nova reforma do CPC, p. 48). Pertinentes, outrossim, as considerações de Sydney Sanches, ao afirmar que o denunciado "poderá apresentar sua defesa até o momento dessa segunda audiência, que não poderá ser realizada em prazo inferior a 10 dias, contados de sua citação (art. 278 do CPC)" (Denunciação da lide no direito processual civil brasileiro, $\mathrm{p}$. 169).

${ }^{298}$ Com propriedade, Celso Agrícola Barbi diz que o prazo de defesa do denunciado "terminará na audiência de instrução e julgamento, cuja data já deve ser avisada ao denunciado, uma vez que não é prazo legal, mas judicial, isto é, assinado pelo juiz" (Comentários ao código de processo civil, n. 413, p. 346).

${ }_{299}$ Cf. Sydney Sanches, Denunciação da lide no direito processual civil brasileiro, p. 244 e Antonio Carlos de Araújo Cintra, Do chamamento à autoria, p. 164. Em sentido diverso, por considerar que o denunciado torna-se litisconsorte do denunciante, Clito Fornaciari Júnior diz que, no caso de a denunciação ter sido feita pelo réu, o denunciado "poderá apresentar reconvenção tanto ao autor originário, como ao denunciante, dado que, visto o processo como um todo, é duplamente réu" (Da reconvenção no direito processual civil brasileiro, p. 97).
} 
direito de apresentá-la, mas tanto pode afetá-la, como ainda repercutir na continuidade do processo principal e da própria ação de regresso.

É necessário, pois, considerar essas possibilidades.

6.3.1. Da revelia do denunciante e denunciação da lide. Se o denunciante for o réu, deverá requer a citação do denunciado, no prazo para contestar (art. 71 do CPC). Poderia o denunciante simplesmente denunciar a lide e não apresentar a contestação? Se sim, quais seriam as consequências processuais?

O legislador não condiciona a possibilidade de o réu denunciar a lide à apresentação de contestação. Apenas estabelece que a denunciação deve ser requerida "no prazo para contestar", o que não significa que as duas posições devam ter lugar, não sendo possível conferir interpretação restritiva ao dispositivo.

No caso de o réu revel ser citado por edital ou com hora certa, é necessário nomear curador especial para representá-lo (art. $9^{\circ}$, II, do CPC), a fim de apresentar defesa. Não é possível a esse curador, todavia, denunciar a lide para terceiro, por consistir a denunciação da lide autêntica ação de regresso, mas não simples defesa. No caso de o Ministério Público atuar como curador especial, mais ainda, pois este, além disso, só poderá exercer o direito de ação nos casos previstos em lei (art. 81 do CPC).

No comum dos casos, se o réu não contestar e requerer apenas a denunciação da lide, sua revelia será decretada. Apesar disso, não é possível concluir, genericamente, que os fatos afirmados pelo autor serão reputados verdadeiros, nos termos do art. 319 do Código de Processo Civil, não se aplicando o efeito da revelia, se o caso concreto enquadrar-se em hipótese que prevê sejam elididos seus efeitos. Se houver pluralidade de réus e um deles contestar a ação (art. 320, I, do CPC), se o litígio versar sobre direito indisponível (art. 320, II, do CPC) ou se a petição inicial não estiver acompanhada de instrumento público indispensável (art. 320, III, do CPC), não será caso de aplicar referida presunção legal. 
A hipótese do inciso I do art. 320 é particularmente interessante para o caso, pois estabelece que a revelia não induz o efeito do art. 319 , se houver pluralidade de réus e algum deles contestar a ação. Para a corrente que classifica o denunciado como litisconsorte do denunciante, em vista de o art. 75, I, do Código de Processo Civil conferirlhe esse tratamento, não há nenhuma dúvida de que, se o denunciado contestar, impugnando os fatos constitutivos do direito do autor, os efeitos da revelia não serão produzidos $^{300}$. Por equiparar a posição do denunciado à do réu, a presunção de veracidade dos fatos alegados pelo autor será afastada, desde que aquele conteste tempestivamente.

Mesmo caso se considere, como entendemos, que a posição do denunciado é de assistente, apresentada sua contestação, os efeitos da revelia não se aplicam Ele atuará na condição de gestor de negócios do denunciante (art. 52, parágrafo único, do CPC), sempre em benefício deste ${ }^{301}$, tendo maior liberdade no processo. É caso, pois, de concordar com a conclusão de DANIEL AMORIM ASSUMPÇÃO NEVES, no sentido de que - em razão de ele deter uma "dupla posição", sendo réu na lide secundária e assistente na ação principal - tem "um prazo próprio para responder", pois o sistema admite "que, nesse mesmo prazo, além de manifestar-se quanto à denunciação, o denunciado exerça sua atividade de assistente, inclusive com a impugnação dos fatos narrados pelo autor na peça inicial, o que virá a indubitavelmente evitar que o juiz presuma verdadeiros tais fatos"302.

Trata-se, pois, de uma assistência anômala, como desenvolvemos no capítulo em que tratamos da posição processual assumida pelo denunciado. Em vista disso, para elidir os efeitos da revelia na ação principal, não é necessário que o denunciado, tal como um assistente simples, apresente contestação no mesmo prazo do réu-denunciante, o que, aliás, seria impróprio, até porque o denunciado, antes de apresentar sua defesa, precisa conhecer a posição do denunciante quanto à impugnação dos fatos e à pretensão do autor na exordial. Vazia, pois, é a alegação de que a contestação apresentada pelo denunciado só tem o condão de afastar os efeitos da revelia, caso oferecida no prazo para o réudenunciante contestar, como seria exigível do comum dos assistentes.

\footnotetext{
${ }^{300}$ É esse o entendimento de Rita Gianesini, ao afirmar que "ocorrerão os efeitos da revelia do art. 319 na ação principal, desde que ambos deixem de contestá-la (art. 320, n. I) e não se enquadre o caso em nenhuma exceção" (Da revelia no processo civil brasileiro, p. 142).

${ }^{301}$ V. Cássio Scarpinella Bueno, Partes e terceiros no processo civil brasileiro, p. 152.

${ }^{302}$ Intervenção de terceiros e revelia, p. 35.
} 


\subsubsection{Da confissão dos fatos pelo denunciante e denunciação da lide. No} curso da demanda, o réu poderá confessar a verdade de fatos contrários ao seu interesse e favoráveis ao do autor, relativo apenas a direitos disponíveis (art. 351 do CPC).

Em razão de a confissão dizer respeito apenas a fatos, o juiz não fica vinculado a ela e pode julgar contra aquele que confessou ou a favor dele. No tema da prova, de qualquer modo, a confissão faz prova contra o confitente, mas não prejudica o denunciado, mormente caso se considere que ele seja litisconsorte do denunciante (art. 350 do CPC).

O processo deve prosseguir, por a confissão ser apenas meio de prova, diferentemente do que se dá quanto ao reconhecimento jurídico do pedido, devendo o julgador, no momento oportuno, decidir as duas lides, por meio de uma única sentença, valorando as provas e, entre elas, a confissão.

Ressalva-se, ademais, que o $\S 2^{\circ}$, do art. 787, do Código Civil é exceção à regra antes exposta. Na hipótese de seguro de responsabilidade civil, "é defeso ao segurado reconhecer sua responsabilidade ou confessar a ação, bem como transigir com o terceiro prejudicado, ou indenizá-lo diretamente, sem anuência expressa do segurador". Assim, só poderá haver confissão dos fatos pelo denunciante nessa hipótese de direito material, caso o denunciado consinta, diante da referida previsão legal ${ }^{303}$. Essa exceção, todavia, não se aplica a outras hipóteses de denunciação da lide, sequer por analogia, pois se deve conferir interpretação restritiva ao dispositivo, por tratar-se de limitação a direito de segurado denunciante, que prevê situação específica de direito material.

\subsubsection{Do reconhecimento jurídico pelo denunciante e denunciação da lide.}

Em se tratando de direito disponível, é possível o reconhecimento jurídico do pedido pelo réu, por meio do qual ele aceita a pretensão do autor, acarretando extinção do processo com resolução do mérito (art. 269, III, do CPC).

\footnotetext{
${ }^{303}$ Jones Figueirêdo Alves comenta, corretamente, que "a ideia da lei objetiva inibir a frustração de eventual direito de segurador, na hipótese de atuação do segurado à sua revelia, quando já se faz, em decorrência do seguro, incabível uma negociação direta entre o segurado e o terceiro sem a anuência expressa do segurador" (O código civil comentado, coord. Ricardo Fiuza, p. 638).
} 
O momento mais coerente para o réu reconhecer juridicamente o pedido é o da resposta, de modo que, nesse caso, sequer haveria oportunidade para pedido de intervenção de terceiros. De qualquer maneira, nada impede que ele reconheça o pedido no curso do processo, após já ter apresentado sua contestação e feito a denunciação da lide.

Se a denunciação da lide for deferida e o réu reconhecer juridicamente o pedido antes da citação do denunciado, o processo principal será julgado extinto com resolução do mérito e o pedido de denunciação, prejudicado.

Citado o denunciado, a depender da posição que se reconheça que ele assume por meio da denunciação da lide, distintas serão as consequências processuais do reconhecimento jurídico do pedido pelo denunciante. Isso posto, analisaremos as diferentes situações.

Se o denunciado for tratado como litisconsorte do denunciante, "o denunciado não terá interesse em prosseguir na ação, pois não se formará contra ele título algum, dado que, para a sentença julgar a ação principal, e, também, a denunciação, é imprescindível a presença do denunciante, uma vez que, do contrário, ocorrerá a perempção do processo eventual" 304 .

Seguindo a postura que defendemos, qual seja, caso o denunciado seja equiparado ao assistente simples, ele não terá como se opor ao reconhecimento feito pelo réudenunciante a quem assiste, em vista dos limites que são impostos ao denunciado, nos termos do art. 53 do Código de Processo Civil. O processo será extinto e a denunciação, por ser instituto associado ao processo de conhecimento, ficará prejudicada, não se formando título executivo judicial contra o denunciado.

Em outra hipótese, qual seja, a de reputá-lo assistente litisconsorcial, o denunciado poderá prosseguir na demanda, pois será atingido pela sentença que extinguir o processo com resolução do mérito. Cumpre também considerar que, no caso de se tratar de seguro de responsabilidade civil, aplica-se a exceção do $§ 2^{\circ}$, do art. 787, do Código Civil;

${ }^{304}$ Cf. Clito Fornaciari Júnior, Reconhecimento jurídico do pedido, p. 40. 
dessa forma, o denunciante só poderá reconhecer juridicamente o pedido com anuência expressa do segurador.

\subsubsection{Da transação entre o denunciante e seu adversário na ação principal e}

denunciação da lide. As partes da ação principal podem celebrar acordo nessa ação principal, o que leva à extinção do processo com resolução do mérito (art. 269, III, do CPC). Se o denunciado não participar de tal transação, ele não poderá ser atingido, nos termos do art. 844 do Código Civil, de vez que "a transação não aproveita, nem prejudica senão aos que nela intervirem".

Essa transação entre as partes relativamente à ação principal logicamente é cabível e produzirá efeitos, independentemente de o denunciado ter ou não ter participado dela. Se assim não for, o denunciante, incoerentemente, perderia a oportunidade de extinguir o litígio da ação principal, que possivelmente lhe seja benéfico.

Existe, no entanto, exceção a essa regra, que convém destacarmos antes de aprofundarmos a questão. No caso de seguro de responsabilidade civil, o segurado só poderá transigir com a parte adversa, desde que tenha o consentimento do denunciado segurador, diante da previsão do $\S 2^{\circ}$, do art. 787, do Código Civil.

Resolvida a ação principal, resta saber quais os efeitos e as consequências da transação em relação à lide secundária.

De um lado, há quem sustente que, sem a participação do denunciado, a transação celebrada pelo denunciante e o seu adversário prejudica a lide secundária, por falta de interesse processual superveniente ${ }^{305}$.

Esse entendimento, todavia, não nos parece correto, por expressa disposição legal, dado que a transação não pode aproveitar ou prejudicar o denunciado, pois dela ele

\footnotetext{
${ }^{305}$ Para essa corrente, diante da transação celebrada pelo denunciante e o seu adversário, a denunciação da lide fica "prejudicada por ausência de interesse processual superveniente", de modo que o processo deve ser extinto, sem resolução de mérito, por perda superveniente do interesse processual (art. 267, IV, do CPC) (cf. TJSP, AP 0128374-89.2004.8.26.0100, Rel. Des. ORLANDO PISTORESI, 30 Câmara de Direito Privado, J. 23/02/2011).
} 
não participou. Assim, como não é possível, por meio da transação, afastar eventual responsabilidade do denunciado, incabível também atribuir-lhe responsabilidade automaticamente, por ele não ter intervindo na composição. Não é possível que o litigante transija sobre direito que não lhe pertence, ficando, portanto, os efeitos da transação só entre os transatores. Apesar disso, é certo que, se o acordo feito pelo denunciante importar em nada pagar à parte contrária, isso retira, por completo, o objeto da lide de regresso.

A única ressalva que ponderamos é quanto à previsão do art. 76 do Código de Processo Civil, ao determinar o julgamento da ação principal e da regressiva na mesma sentença. Fica claro que a intenção do legislador é que a ação e a denunciação da lide sejam julgadas simultaneamente, assim como sucede em relação a ação e a reconvenção (art. 318 do CPC), porém essas regras processuais não têm como impedir a transação, que é instituto de direito material.

De qualquer modo, a também temperar o rigor de se decidir conjuntamente, aponta-se para o $\S 2^{\circ}$, do art. 72 , do texto processual - que, diante da não citação do denunciado no prazo legal, estabelece que a ação prosseguirá unicamente em relação ao denunciante - bem como, por analogia, para o art. 317 do Código de Processo Civil - ao dispor que a reconvenção prosseguirá, na hipótese de desistência da ação ou de qualquer causa que a extinga. Assim, a regra é a ação e a denunciação da lide serem julgadas conjuntamente, mas a interpretação sistemática possibilita que sejam resolvidas em separado.

Não nos parece correto admitir o desmembramento da ação principal da lide secundária, em razão da dificuldade na instrução simultânea de ambas ou de a denunciação estar retardando o processo. No Código de Processo Civil de 1939, isso era possível, por força do disposto no art. 116, ao admitir “o desmembramento dos processos reunidos", o que, todavia, foi suprimido do sistema vigente. Ora, se a prova for útil e relevante para demonstrar fato controvertido, é necessário produzi-la. Se não for, cabe ao julgador indeferi-la, até para velar pela rápida solução do feito (art. 125, II, do CPC). Afigura-se razoável aguardar a instrução processual e não desdobrar o processo, em vista de ele poder 
ficar suspenso, por até um ano, quando a sentença de mérito depender do julgamento de outra causa, como sucede no caso (art. 265, IV, “a”) ${ }^{306}$.

Assim, pode bem o magistrado, a fim de não romper com a unidade da sentença, postergar a homologação do acordo para quando estiver em condição de julgar a ação de regresso.

De outro lado, existe corrente considerando que a lide secundária não se extingue automaticamente e que deve prosseguir para não ficar prejudicada. Parece-nos ser esse o raciocínio correto, de vez que se permite ao denunciante buscar ressarcir-se no mesmo processo, por força de a lide secundária subsistir, e ao denunciado, realizar defesa efetiva. Dessa maneira, o processo prosseguiria com a denunciação como lide autônoma, podendo o denunciado invocar, por exemplo, a ausência de responsabilidade do denunciante, que precipitadamente celebrou o acordo, apontando falta de regular defesa naquele feito; o não cabimento da denunciação da lide; ou a limitação da cobertura da apólice.

Essa posição é defendida na doutrina por SYDNEY SANCHES ${ }^{307}$ e ATHOS GUSMÃO CARNEIRO ${ }^{308}$, havendo, nessa mesma linha, acórdãos do Superior Tribunal de Justiça $^{309}$ e do Tribunal de Justiça de São Paulo ${ }^{310}$.

Para assim considerar, pondere-se apenas que o denunciante não deve, por lógico, desistir da lide secundária e que os termos da transação não podem inviabilizar o prosseguimento da ação regressiva. Em tese, o interesse do denunciante na lide secundária mantém-se, em razão de a denunciação ser ação regressiva, eventual e condicionada à demanda principal. Se a lide secundária for declarada prejudicada por força da transação, o

${ }^{306}$ Em sentido diverso, Milton Flaks, ao sustentar a possibilidade de desdobramento do processo (Denunciação da lide, p. 152-154).

${ }^{307}$ Sustenta que a transação não "afetará eventual responsabilidade do denunciado" e que a lide secundária deverá prosseguir, "para se saber se o denunciado deve ou não ser condenado a alguma indenização perante o denunciante" (Denunciação da lide no direito processual civil brasileiro, p. 224).

${ }^{308}$ Afirma que a homologação judicial irá extinguir a demanda originária (CPC, art. 269, III), "mas em princípio não prejudicará a demanda regressiva, já agora tornada 'autônoma"”, podendo o denunciado resistir, até porque os fundamentos da transação "não vinculam o terceiro a quem a lide originária foi denunciada" (Intervenção de terceiros, n. 58, p. 160).

${ }^{309}$ REsp 316.046/SP, Rel. Min. LUIS FELIPE SALOMÃO, 4a Turma, J. 17/02/2009.

${ }^{310}$ AP 0114004-76.2007.8.26.0011, Rel. Des. ADILSON DE ARAÚJO, $31^{\text {a }}$ Câmara de Direito Privado, J. $10 / 04 / 2012$. 
denunciante terá que ajuizar nova ação em face do denunciado, o que não se ajusta aos princípios processuais, a revelar que não há razão para considerá-la assim.

De qualquer maneira, o denunciado persiste, podendo discutir se efetivamente o denunciante tinha responsabilidade, dado que a transação não restringe seu direito de defesa, qualquer que seja sua posição processual. O denunciado, até mesmo se for considerado assistente simples, não fica impedido de debater sobre a "justiça da decisão", ao passo que, se for litisconsorte - o que se admite para fins de exposição - não pode ser prejudicado pela transação, em razão de somente os atos benéficos terem aptidão de atingilo pela regra do art. 48 do Código de Processo Civil.

A lei não faz, por exemplo, distinção quanto ao pagamento de indenização pelo denunciante, por força de ter sucumbido ou transigido. Não é possível interpretar diferentemente, a partir do disposto no inciso III, do art. 70, do texto processual, ao estabelecer que o denunciado será condenado a indenizar, em ação regressiva, o "prejuízo do que perder a demanda", que nem sempre será aquele assumido por ele na transação. Uma das finalidades do instituto é a do ressarcimento, de modo que há de se conferir interpetação sistemática aos dispositivos que o regulam, não se podendo considerar que, por o denunciado não ter perdido tecnicamente a ação, mas transigido, o regresso é indevido.

Além disso, os litigantes da lide secundária não são devedores solidários do adversário da denunciante por não se tratar de chamamento ao processo. Desse modo, não se aplica a regra do $\S 3^{\circ}$, do art. 844, do Código Civil, que estabelece a extinção da dívida, se a transação for realizada entre um dos devedores solidários e seu credor.

Assim, se o denunciante transigir, a lide secundária prosseguirá e poderá ser julgada procedente, caso sejam demonstradas a responsabilidade do denunciado, bem como os fatos constitutivos do direito dele. Ressalve-se, no entanto, que eventual indenização a ser definida na lide secundária estará limitada ao valor objeto da transação e a execução, condicionada à comprovação do pagamento ao adversário do denunciante. 


\subsubsection{Da preliminar de ilegitimidade passiva na ação principal e} denunciação da lide. O réu, ao apresentar contestação, pode alegar, à guisa de preliminar, sua ilegitimidade passiva para a causa, o que, todavia, não o impede de denunciar a lide para terceiro.

Num primeiro momento, essa possibilidade parece incoerente, mas não existe contra ela, na realidade, qualquer restrição legal. A denunciação é uma ação regressiva e eventual, sendo, pois, condicionada à ação principal, de modo que é possível o réu arguir sua ilegitimidade para figurar no polo passivo e requerer, no prazo para contestar, a denunciação da lide, por se tratar de demanda secundária. Simultaneamente, o réu denunciante diz nada ter com a ação principal, mas, se perder, poderá valer-se da ação regressiva.

A denunciação da lide, no entanto, não constituiu meio de substituir a parte passiva $^{311}$, de modo que consideramos não se ajustar à essência do instituto declarar a ilegitimidade passiva do réu denunciante e determinar o prosseguimento do processo apenas contra o denunciado ${ }^{312}$.

Diante da possibilidade de o réu sucumbir na ação principal, é evidente que ele possui interesse em denunciar a lide. Esse direito fica ainda mais manifesto, caso se trate de denunciação da lide obrigatória, em vista das implicações decorrentes da sua ausência; não há como impedir, porém, que também seja realizada nas hipóteses de denunciação facultativa.

Por serem distintas as relações de direito material entre o autor e o réu e entre este e o denunciado, contudo, não existe impedimento para a concomitância de ações ${ }^{313}$. Basta para viabilizar a denunciação que os requisitos legais estejam presentes e que o denunciado esteja obrigado, pela lei ou pelo contrato, a indenizar o prejuízo do denunciante, em ação regressiva.

\footnotetext{
${ }^{311}$ Cf. Gelson Amaro de Souza, ao afirmar não ser "a denunciação da lide instituto apropriado para operar a substituição de parte na relação principal entre o adversário e o denunciante. Em outros termos, não se destina a espécie à substituição do denunciante pelo denunciado" (Cumprimento de sentença diretamente contra o denunciado, p. 14).

${ }^{312} \mathrm{O}$ Superior Tribunal de Justiça já reconheceu que "a denunciação da lide não se presta à substituição da parte passiva" (AgRg no Ag 161.451/RJ, Rel. Min. SÁLVIO DE FIGUEIREDO TEIXEIRA, 4ª Turma, J 30/04/1998, DJ 22/06/1998, p. 104).

${ }^{313}$ Cf. STJ, REsp 23.039/GO, Rel. Min. SÁLVIO DE FIGUEIREDO, 4ª Turma, J. 25/11/1992.
} 
Cumpre destacar que o momento para o réu denunciar a lide acontece "no prazo para contestar" (art. 71 do CPC), de modo que, pelo princípio da eventualidade, competelhe, sob pena de preclusão temporal, denunciar a lide para terceiro. Como não cabe aguardar a decisão sobre a ilegitimidade passiva, o réu deve, simultaneamente, arguir a preliminar e requerer a denunciação. As alegações não são incompatíveis ${ }^{314}$, por haver uma relação de subsidiariedade entre elas, de modo que "rejeitada a tese de ilegitimidade passiva, passa-se ao exame da denunciação da lide"315.

Com efeito, se a ilegitimidade for reconhecida, a ação principal será extinta, sem resolução do mérito, e a denunciação da lide, caso tenha sido deferida, ficará prejudicada. Por o adversário do denunciante não manter qualquer relação de direito material com o denunciado, a denunciação não servirá sequer para corrigir a legitimidade passiva, não se confundindo com o instituto da nomeação à autoria.

De outro lado, na hipótese de a preliminar de ilegitimidade passiva ser afastada, a lide secundária prosseguirá, não se restringindo o direito de o réu-denunciante arguir sua ilegitimidade e permitindo-se, ao mesmo tempo e no mesmo processo, que ele busque sua pretensão regressiva. Isso se ajusta ao sistema processual e só reforça a pertinência das alegações, apesar de serem aparentemente conflitantes.

6.4. Do prazo para citação do denunciado. Ordenada a citação do denunciado, ela deve ser feita, nos moldes do art. 72 do Código de Processo Civil. Se ele residir na mesma comarca, deverá ser realizada sua citação em dez dias, mas se for em outra comarca ou lugar incerto, em trinta dias (art. 72, $\$ 1^{\circ}$, letras “a” e "b”, do CPC).

Não se efetivando a citação no prazo marcado, por culpa ou desídia do denunciante, o processo prosseguirá unicamente entre o autor e o réu, considerando-se

\footnotetext{
${ }^{314}$ Cf. Rogéria Dotti, ao dizer que, "apesar da denunciação da lide ter como pressuposto a legitimidade e a sucumbência (condenação com base em exame do mérito), conclui-se não haver verdadeira incompatibilidade diante do princípio da eventualidade e da aplicação da garantia constitucional da ampla defesa. Ou seja, ainda que o réu se considere parte ilegítima e procure comprovar tal condição, pode ele ao mesmo tempo denunciar a lide a um terceiro para a eventualidade de um entendimento diverso por parte do magistrado. Isto porque todas as teses possíveis devem estar abrangidas dentro da garantia da ampla defesa" (A denunciação da lide e a ilegitimidade passiva ad causam, p. 468).

${ }^{315}$ STJ, AgRg no Ag 671.524/SC, Rel. Min. HUMBERTO GOMES DE BARROS, $3^{\text {a }}$ Turma, J. 23/11/2005. 
ineficaz a denunciação e afastando-se, portanto, o denunciado, por não ter sido citado; assim sendo, os efeitos da sentença não lhe atingirão por não ser parte, arcando o denunciante com as consequências decorrentes.

De qualquer modo, caso a citação não seja realizada no prazo legal por circunstância que não possa ser atribuída ao denunciante ${ }^{316}$, não é possível cogitar que este, mesmo na hipótese do inciso I, do art. 70, perca, definitivamente, o direito à indenização decorrente dos prejuízos da evicção. Por inexistir culpa do denunciante pela demora em efetivar a citação, a consequência revela-se desproporcional, impondo-se conferir tratamento mais flexível e permitir o prosseguimento do processo, mas facultando oportunidade, por outro lado, de o denunciante buscar autonomamente o ressarcimento caso seja vencido.

Nas hipóteses dos incisos II e III, inexiste, muito menos, o risco de perda do direito, sendo que a consequência da falta de citação restringe-se a não ter o denunciante o auxílio do denunciado na defesa, a não se obter o título executivo judicial contra o denunciado nos mesmos autos e ao risco de o denunciante sucumbir eventualmente na ação regressiva futura. Dessa maneira, se não houver tempo hábil para a citação, ocorre a perda da eficácia do pedido de denunciação da lide e o processo prosseguirá apenas entre o autor e o réu, sem prejuízo de oportuna ação de regresso.

Essa questão do prazo para citar o denunciado merece ser revista pelo legislador, pois se tornou, na prática, difícil de ser contornada, em vista do diminuto prazo legal estabelecido de dez e trinta dias ${ }^{317}$, quando o denunciado residir, respectivamente, na mesma ou em outra comarca. Assim, consideramos necessário ampliar esse prazo para a citação ser realizada $^{318}$.

\footnotetext{
${ }^{316}$ Athos Gusmão Carneiro arrola, de maneira exemplificativa, várias hipóteses em "que a demora na citação resulte não da conduta do denunciante, mas sim de deficiência dos próprios serviços judiciários (oficial de justiça, v. g. omisso no cumprimento do mandado, ou com acúmulo de serviço), ou decorra de força maior (greve dos transportes, inundações etc), ou seja consequência das próprias circunstâncias da causa, que impossibilitem ou dificultem extremamente a observância dos limitados prazos em lei (v. g., casos de denunciado residente no estrangeiro, ou em viagem, ou paciente de doença grave ou morador em local distante com problemas no cumprimento da precatória citatória" (Intervenção de terceiros, n. 52.1., p. 142).

317 O art. 96 do Código de Processo Civil de 1939 estabelecia os prazos de 8 dias para citar o denunciado residente na mesma comarca e de 30 dias para aquele em comarca diversa, tendo sido timidamente ampliado quanto à primeira determinação.

${ }^{318} \mathrm{O}$ art. 333 do Código de Processo Civil português estabelece prazo de três meses para a citação, a contarse da data em que foi inicialmente deduzido. Decorrido esse prazo, faculta-se ao autor requerer o 
Além de dilatar esse prazo, revela-se oportuna a sugestão de SYDNEY SANCHES de prorrogá-lo até que a citação se efetive, na hipótese de não ter havido má-fé ou culpa do denunciante ${ }^{319}$. É claro que essa prorrogação não pode ser excessiva, devendose ajustá-la para que se busque um equilíbrio, de forma a não prejudicar tanto a parte adversa do denunciante - que tem o direito de ter a prestação da tutela jurisdicional, prestigiando a razoável duração do processo - como o próprio denunciante - a quem é assegurado valer-se desse instituto para eventualmente poder ser ressarcido na mesma demanda.

A questão, de qualquer maneira, desafia o disposto no art. 72 do Código de Processo Civil, expresso quanto ao prazo de suspensão do processo principal, mas em desarmonia com a atual realidade do cotidiano forense, em vista de serem extremamente exíguos os prazos estabelecidos, quase impossíveis de serem cumpridos. Se não forem revistos, a aplicação do instituto estará praticamente descartada ou a previsão legal se tornará letra morta.

$\mathrm{Na}$ hipótese de o denunciado estar em lugar incerto, a citação terá que ser feita por edital. Da mesma forma deverá ocorrer se o denunciante desconhecer o paradeiro do denunciado, após o insucesso da citação realizada por oficial de justiça ou por carta. No caso de citação do denunciado por edital, impossível será cumprir a citação no prazo legal da letra "b", do $\S 1^{\circ}$, do art. 72 , do texto processual, diante da complexidade que envolve essa modalidade de citação e do tempo do próprio edital. Em vista disso, existe consenso na doutrina, com o qual concordamos, que o prazo de trinta dias, "quando a citação tiver que ser feita por edital, deve ser para os atos iniciais deste, e não para sua complementação, que, normalmente, leva prazo superior" ${ }^{320}$.

De qualquer maneira, se a citação não se efetivar, o processo deverá prosseguir unicamente em relação ao denunciante (art. $72, \S 2^{\circ}$, do CPC), sem a ação de regresso.

prosseguimento da causa principal. O dispositivo lusitano parece-nos mais realista no tocante ao prazo de citação e, caso todas as citações não tenham sido realizadas, deixa, de maneira interessante, a critério do autor o prosseguimento ou não da demanda.

${ }^{319}$ Denunciação da lide no direito processual civil brasileiro, p. 63.

${ }^{320}$ Celso Agrícola Barbi, Comentários ao Código de Processo Civil, p. 346-347; Moacyr Amaral Santos, Primeiras linhas de direito processual civil, p. 31; Sydney Sanches, Denunciação da lide no direito processual civil brasileiro, p. 174. 
Todavia, este não pode ser prejudicado, caso a demora da citação não aconteça por culpa sua.

Em vista dessa real dificuldade em citar o denunciado, o sentido de obrigatoriedade de denunciação decorrente de evicção deve ser temperado. Na realidade, o art. 456 do Código Civil estabelece que o adquirente deverá notificar o alienante do litígio, "quando e como the determinarem as leis do processo". Não sendo possível fazê-lo no prazo do art. 72 do texto processual, em vista de o processo principal não poder ficar suspenso de modo indefinido, a denunciação, sem prejuízo do prosseguimento da lide, terá que ser feita, como considera JOSÉ IGNÁCIO BOTELHO DE MESQUITA, a fim de, ao menos, notificar o denunciado para que ele possa, se quiser, atuar "como assistente simples do denunciante, cabendo ao denunciante, reconhecida a evicção, propor ação regressiva" 321 .

A propósito, OVÍDIO ARAÚJO BATISTA DA SILVA assevera ser perfeitamente admissível a denunciação tardia sem simultânea propositura da ação de regresso, e conclui ser "evidente que o denunciante não poderá ficar privado do direito de proceder à denunciação, a fím de possibilitar o ingresso do denunciado como seu assistente, na luta contra terceiro molestante, de modo que o responsável pela indenização, que legitima a denunciação, fique exposto aos efeitos do art. 55 ${ }^{, 322}$. Esse raciocínio parecenos correto, em razão de estar em sintonia com o caráter de assistência da denunciação e vincular, relativamente às questões do direito do regresso, o denunciado, que não poderia resistir aos efeitos da sentença, tal como estabelece o art. 332 do Código de Processo Civil português.

6.5. Dos desdobramentos da denunciação da lide feita pelo réu. Feita a denunciação pelo réu no prazo para contestar e consumada a citação, existe a possibilidade de desdobramento, que depende da postura assumida pelo denunciado. $\mathrm{O}$ art. 75 do Código de Processo Civil estabelece que, se este aceitar a denunciação e contestar o pedido, o processo prosseguirá entre o autor, de um lado, e de outro, o denunciante e o denunciado, como "litisconsortes" (inciso I); caso seja revel ou compareça apenas para negar a

${ }^{321}$ Da ação de evicção, p. 94.

${ }^{322}$ Comentários ao Código de Processo Civil, p. 346. 
qualidade que lhe foi atribuída, cumprirá ao denunciante prosseguir na defesa até o final (inciso II); se o denunciado, de outra forma, confessar os fatos alegados pelo autor, poderá o denunciante prosseguir na defesa (inciso III).

Antes de qualquer consideração, ressalte-se que essas disposições legais são imprecisas e causam confusão por não tratarem a estrutura do instituto com o necessário rigor técnico, o que gera diferentes interpretações e insegurança ao próprio sistema processual $^{323}$.

Acrescente-se, ainda, que qualquer que seja a postura assumida pelo denunciado, cumprirá ao denunciante seguir na defesa até o final. É indiferente se o denunciado aceitou a denunciação e contestou o pedido, se ficou revel, ou se confessou. Trata-se de um ônus que todo réu possui, mesmo que o denunciado seja diligente, principalmente nesse caso em que existem duas ações e o réu é autor da segunda.

6.5.1. Da aceitação da denunciação pelo denunciado. Ao contrário do que possa transparecer a previsão do inciso I, do art. 75, do Código de Processo Civil, o denunciado não tem a faculdade de "aceitar" ou "não aceitar" a denunciação da lide, assim como ocorre relativamente à denunciação da lide feita pelo autor. Qualquer que seja o comportamento do denunciado, ele será sempre réu na lide secundária.

Se o denunciado "aceitar e contestar o pedido", é impróprio considerar que haverá litisconsórcio entre eles - como desenvolvemos no capítulo destinado a tratar da posição processual do denunciado - dado que há duas lides distintas: na ação principal, o autor contende com o réu, e na lide secundária, o denunciante com o denunciado.

Na realidade, "se o denunciado aceitar e contestar o pedido", ele poderá impugnar o próprio pedido da ação principal, auxiliando o denunciante. Em outras palavras, o

\footnotetext{
${ }^{323}$ Cândido Rangel Dinamarco critica, com propriedade, a redação do art. 75 do Código de Processo Civil, dizendo que "o legislador de 1973 limitou-se a transcrever ou apenas adaptar formalmente algumas disposições que estavam no Código anterior, sem se aperceber da grande diferença substancial e de estrutura entre a disciplina do instituto nos dois Códigos", concluindo que algumas proposições, se interpretadas literalmente, conduzem a resultados de todo inaceitáveis" porque em profundo conflito com o sistema vigente" (Instituições de direito processual civil, v. II, n. 606, p. 407). Athos Gusmão Carneiro também critica a redação do dispositivo, afirmando que "parece redigido sob certa influência da sistemática do Código de Processo Civil de 1939" (Intervenção de terceiros, n. 55, p. 150).
} 
denunciado poderá atuar ativamente, inclusive na demanda principal, colaborando com a defesa do denunciante ${ }^{324}$.

Além disso, o denunciado, antes de discutir o mérito, poderá opor preliminares processuais, como incompetência absoluta, inépcia da petição inicial, perempção, litispendência, coisa julgada, conexão, incapacidade do autor, defeito de representação, compromisso arbitral, carência da ação, falta da caução ou de outra prestação (art. 301 do CPC). Poderá, ainda, impugnar o valor da causa (art. 261 do CPC), bem como apresentar exceção de impedimento e de suspeição (art. 312 do CPC), mas não caberá reconvir em face do adversário do denunciante.

6.5.2. Da revelia do denunciado. $O$ denunciado é citado para, se quiser, impugnar a denunciação, mas também a própria ação principal, pois uma das finalidades do instituto é auxiliar a defesa do denunciante, como já foi destacado neste estudo.

Se o denunciado for revel ou simplesmente negar a qualidade que lhe foi atribuída (art. 75, II, do CPC), o réu denunciante não terá o auxílio daquele para opor-se à pretensão do autor. Essa postura não evitará que, em face dele, seja proferida sentença nos termos do art. 76 do Código de Processo Civil. De qualquer modo, a revelia do denunciado não acarretará a presunção de que os fatos constitutivos do direito do autor da ação principal são verdadeiros, até mesmo porque o revel não é parte na lide principal e não tem relação de direito material com o adversário do denunciante.

Diante da revelia, o denunciante deverá "prosseguir na defesa até final”, mesmo porque a ação principal the foi promovida, valer-se, ainda mais, de todos os meios para afastar a pretensão do autor e, no caso de a ação ser julgada procedente, buscar que a ação regressiva também assim seja julgada, condenando-se o denunciado.

\footnotetext{
${ }^{324}$ V., nesse sentido, interessante acórdão do Superior Tribunal de Justiça, da pena do Ministro SIDNEI BENETI, que deu provimento a recurso especial, a fim de anular a sentença, que restringiu a denunciada de "adentrar no âmbito da lide primária". Considerou que o denunciado tem "interesse em oferecer resistência, de forma ampla, à pretensão deduzida pelo adversário do denunciante, tendo em vista que o desfecho conferido à demanda principal poderá repercutir na demanda secundária", independentemente da "natureza

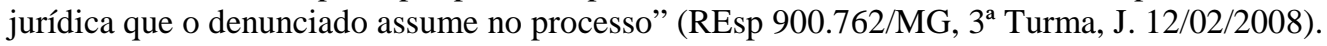


Com a revelia do denunciado, os fatos afirmados pelo denunciante na lide secundária serão, em tese, considerados verdadeiros, aplicando-se os efeitos dessa revelia; isso se dá a menos que o litígio verse sobre direito indisponível ou falte instrumento público, que a lei considera indispensável à prova do ato (art. 320, II e III, do CPC).

Ocorre, todavia, que, ainda que se verifique a revelia na lide secundária e mesmo que os fatos sejam tidos como verdadeiros, ela não implica necessariamente a procedência da denunciação. Na realidade, a ação principal poderá ser julgada improcedente, hipótese que torna prejudicada a denunciação. Além disso, ainda que a ação seja julgada procedente, a lide secundária poderá ser julgada improcedente, se "ficar evidenciado, na ação principal, que não há direito regressivo a favor do denunciante" 325 .

Nesse sentido, o Superior Tribunal de Justiça tem reconhecido ser relativa essa presunção, de modo que ela pode "ceder a outras circunstâncias constantes dos autos, de acordo com o princípio do livre convencimento do juiz", afastando o direito de regresso contra o denunciado ${ }^{326}$.

Por força de não ser inexorável a derrota do denunciado-revel é que se põe a imprescindibilidade de o denunciante prosseguir na defesa até o final para demonstrar seu direito regressivo.

É certo, outrossim, que o denunciado, mesmo sendo revel, poderá intervir no processo em qualquer fase, recebendo-o no estado em que se encontrar, nos termos do art. 322 do Código de Processo Civil. Apesar de não ter oferecido contestação, poderá, de outro lado, contribuir na defesa do denunciante e produzir provas, caso tenha ingressado no processo até esta fase, à luz da súmula 231 do Supremo Tribunal Federal, segundo a qual "o revel, em processo civil, pode produzir provas, desde que compareça em tempo oportuno".

\footnotetext{
${ }^{325}$ Rita Gianesini, Da revelia no processo civil brasileiro, p. 143.

${ }^{326}$ REsp 86.109/SP, Rel. Min. BARROS MONTEIRO, $4^{\text {a }}$ Turma, J 28/06/2001; REsp 47.107/MT, Rel. Min. CESAR ASFOR ROCHA, $4^{\text {a }}$ Turma, J. 19/06/1997; e REsp 38.325/PB, Rel. Min. DIAS TRINDADE, $4{ }^{\text {a }}$ Turma, J 11/10/1993.
} 
6.5.3. Da confissão dos fatos pelo denunciado. $O$ art. 75 , III, do Código de Processo Civil estabelece a possibilidade de o denunciado confessar os fatos alegados pelo autor, porém faculta ao denunciante prosseguir na defesa.

A confissão é prova mais forte do que a presunção que decorre da revelia, mas, por afetar somente os fatos, não confere certeza de vitória. O denunciante não será prejudicado pela confissão dos fatos pelo denunciado, mas terá o ônus de provar o contrário do confessado e, ainda, eventualmente, fatos modificativos, impeditivos ou extintivos do direito do autor, que possam levar à improcedência da ação principal.

Dessa maneira, o denunciante não será prejudicado, mesmo que se admita, diferentemente do que sustentamos, que a sua posição jurídica seja a de um verdeiro litisconsorte, nos termos do art. 350 do Código de Processo Civil, razão pela qual pode prosseguir na defesa ${ }^{327}$.

6.5.4. Do reconhecimento jurídico do pedido pelo denunciado. Embora não esteja arrolado nas hipóteses do art. 75 do texto processual, o denunciado poderá, ainda, reconhecer juridicamente o pedido.

Para admitir o reconhecimento pelo denunciado, sua posição processual deverá ser a de litisconsorte ou a de assistente litisconsorcial, mas não a de assistente simples do denunciante, como sustentamos, em razão dos poderes que possui e de nada ser pedido contra ele.

O reconhecimento jurídico do pedido pelo denunciado não pode prejudicar o denunciante. Em vista disso, este pode prosseguir na defesa até o final ou também aceitar contra si os efeitos daquele ato, de modo que a ação principal e a lide secundária possam ser julgadas procedentes.

\footnotetext{
${ }^{327}$ Athos Gusmão Carneiro vai além e considera que o denunciante, além da possibilidade de prosseguir na defesa até o final, pode aderir à confissão feita "pelo denunciado, postulando apenas, em consequência, seja julgada procedente a ação regressiva" (Intervenção de terceiros, n. 58, p. 159). Existe essa possibilidade de o denunciante aderir à confissão; no entanto, discordamos da consequência, em razão de isso não significar, por si só, que a lide secundária será julgada procedente, por a confissão gerar presunção apenas relativa e consistir prova, ao contrário do que se dá no reconhecimento jurídico do pedido.
} 
Na hipótese de ser possível o reconhecimento, o denunciante terá duas opções, por aplicação analógica do iniciso III, podendo, como expõe CLITO FORNACIARI JÚNIOR, "desde logo aceitar o reconhecimento, dando, assim, ganho de causa ao autor original, e se munindo com a sentença, que terá, necessariamente que julgar procedente a ação eventual, para voltar-se contra o denunciado" ou "optar por se defender até o final, podendo vir a ganhar a demanda, com o que a denunciação ficará prejudicada, e, apesar do reconhecimento, o denunciado não será afetado" ${ }^{\text {,328 }}$.

\subsubsection{Da transação entre o denunciado e o adversário do denunciante. $O$} denunciado poderá, em tese, celebrar acordo diretamente com o adversário do denunciante, sem a participação do denunciante, pagando indenização para aquele.

Isso só será possível, caso o denunciado seja considerado litisconsorte, o que não admitimos, dado que, se for assistente, os poderes que lhe são conferidos não permitem transigir sobre direitos controvertidos.

Admitida a possibilidade de transação, ela pode esvaziar o interesse do autor quanto à ação principal, mas, de qualquer modo, não afasta a responsabilidade do denunciante, que não pode, todavia, ser prejudicado, nos termos do art. 844 do Código Civil. Faculta-se ao segurador (denunciado), por exemplo, celebrar transação extrajudicial ou judicial diretamente com a vítima (adversário do denunciante), pagando indenização até o limite da apólice, o que, todavia, pode ser inferior ao que a vítima tem direito, de modo que subsiste a responsabilidade do segurado (denunciante) e o interesse do autor em prosseguir a ação.

Nesse caso, não é possível "afastar por completo a responsabilidade civil do causador do dano, tampouco obsta a instauração do processo em face deste",329. Ao menos, parcialmente, a transação aproveitará ao denunciante, dado que a sua responsabilidade existirá, no máximo, quanto ao que exceder do acordo celebrado.

\footnotetext{
${ }^{328}$ Reconhecimento jurídico do pedido, p. 40.

${ }^{329}$ Cf. STJ, REsp 506.917/MG, Rel. Min. LUIS FELIPE SALOMÃO, $4^{\text {a }}$ Turma, J 01/12/2009. 
Se o valor da indenização estabelecida no acordo firmado pelo autor e o denunciado for inferior ao limite da apólice, não há como restringir a obrigação do denunciado, caso a ação e a denunciação forem julgadas procedentes. Na realidade, é permitido ao autor, diante da relação de direito material, cobrar do réu-denunciante a indenização a que tem direito, o qual, todavia, não pode restar prejudicado, por não ter participado do acordo. O seu direito de regresso não deve, portanto, ser afetado ou restrito pela transação da qual não participou.

\subsection{Do recurso contra a decisão sobre cabimento da denunciação da lide.}

Feita a denunciação da lide pelo autor ou pelo réu, caberá ao julgador apreciar o pedido e aferir se, no caso, estão presentes os pressupostos legais para deferir a denunciação. Não é possível retardar a decisão sobre o cabimento da intervenção, até porque o denunciado, se a denunciação for feita pelo autor, poderá aditar a petição inicial, de modo a anteceder este exame a própria determinação de citação do réu. É contemporâneo, porém, a essa decisão o exame da admissibilidade da inicial, de vez que a citação do réu só será ordenada se a inicial tiver condições de ser recebida.

Incabível também postergar a decisão sobre o deferimento da denunciação feita pelo réu, em razão de o processo dever prosseguir, permitindo um contraditório equilibrado. Caso assim não se proceda e sejam praticados outros atos processuais, após a denunciação ser requerida, esses atos deverão ser declarados nulos, pois é inegável o direito de o denunciado participar do processo desde o momento processual em que a denunciação deveria ter sido deferida, facultando-lhe atuar ativamente, praticando todos os atos e participando, se for o caso, da produção de provas.

Qualquer que seja a decisão quanto ao cabimento da denunciação da lide, deferindo ou indeferindo o pedido, caberá a interposição de agravo, por se tratar de decisão interlocutória (art. 522 do CPC). O recurso poderá ser interposto pelo denunciante e ou pelo adversário do denunciante, de vez que eles podem, em tese, ser prejudicados pela decisão. Relativamente ao denunciado, a questão comporta melhor análise, não sendo admissível a interposição de recurso desde logo por ele, dado que, neste momento, seu recurso seria como o do réu que foi citado, razão pela qual terá que se limitar a apresentar sua defesa, sustentando as razões pelas quais entende que não deveria ser trazido ao feito. 
Logicamente, mais para diante, quando sua alegação de que os pressupostos da denunciação não estão presentes for examinada, poderá, se for mantido na demanda, agravar. Antes, falta-lhe interesse.

A regra no sistema processual vigente é a de interposição do agravo sob a forma retida, exceto nas hipóteses do art. 522 do Código de Processo Civil, entre as quais não está expressamente prevista a decisão que resolve sobre o cabimento da denuciação da lide. Apesar disso, consideramos que só caberá a interposição de agravo na modalide de instrumento, não o retido, por "se tratar de decisão suscetível de causar à parte lesão grave e de difícil reparação".

Dessa forma, tendo sido deferida a denunciação, não se revela adequada a interposição de agravo retido. Por primeiro, o recurso só seria apreciado pelo Tribunal, ao julgar a apelação - o que postergaria a definição do cabimento da denunciação - enquanto inúmeros atos seriam praticados e provas, eventualmente inúteis e desnecessárias, produzidas, movimentando desnecessariamente a máquina judiciária. De outro lado, se a denunciação fosse indeferida, o processo prosseguiria sem a participação do denunciado e se, ao final, a interveção fosse considerada admissível, os atos praticados seriam anulados, retrocedendo o processo, com enorme perda de tempo e de atividade jurisdicional prestada, dado que o feito se processaria desde o momento em que o denunciado fora excluído da demanda.

Além disso, o denunciado poderia recorrer para ser afastado da lide secundária, caso houvesse descabimento evidente da intervenção de terceiro, não precisando aguardar, indefinidamente, o trânsito em julgado da sentença, com todos os transtornos de ser réu em uma ação judicial. Se fosse reconhecido que o caso não se amoldava às hipóteses legais dessa modalidade de intervenção de terceiros, já se afastaria o denunciado; assim sendo, este não teria mais seu nome constando no distribuidor forense - o que lhe poderia causar restrições negociais - e não precisaria praticar inúmeros atos processuais, como participar da produção de provas, além de manter advogado remunerado constituído.

Estrategicamente, a admissão da denunciação poderia não ser conveniente ao adversário do denunciante, por não ser essa hipótese de cabimento do instituto e por não lhe interessar a ampliação objetiva e subjetiva do processo, postergando a entrega da 
prestação da tutela jurisdicional. Desse modo, o adversário do denunciante teria interesse em atacar a decisão, a fim de, desde logo, afastar o denunciado do processo, evitando-se a prática de atos que poderiam revelar-se inúteis ao final.

Assim, consideramos que o recurso tecnicamente apropriado contra a decisão que defere a denunciação da lide é o agravo de instrumento, em razão de o decisório poder causar lesão grave e de difícil reparação às partes, bem como por o agravo retido não se amoldar, no caso, aos princípios da economia e da celeridade processual, podendo gerar, até seu julgamento, um segmento inútil ao processo ou, então, deixar o denunciado fora do feito em momento processual em que, sendo ele legitimado a ser denunciado, não poderia ficar.

Se a denunciação da lide for indeferida, o prejudicado também deverá interpor agravo de instrumento em razão de a modalidade retida não ser o meio "processual adequado para o reexame da matéria relativa à intervenção de terceiros" ${ }^{\text {"330 }}$. Se deduzir agravo retido e o recorrente tiver razão quanto ao cabimento da denunciação, necessário será anular todo o processo, desde a decisão que não admitiu a intervenção de terceiro. Todavia, essa anulação não se ajusta à economia processual e ofende a garantia constitucional da duração razoável do processo, de modo que, muito provavelmente, na hipótese de não se tratar de denunciação obrigatória - quando então a parte poderá, em ação autônoma, postular o seu direito - a decisão será mantida e o denunciado não será admitido por mera conveniência.

Com efeito, não é razoável anular o processo, já em estágio avançado, apenas para permitir a instauração da lide secundária, principalmente se não se cuidar de denunciação obrigatória, até porque o denunciante não será prejudicado quanto ao regresso, em razão de poder ajuizar ação autônoma oportunamente em face do que seria denunciado, deixando somente de ter auxílio na sua defesa. Seria uma forma de não se decretar nulidade, se não houver prejuízo.

O Superior Tribunal de Justiça tem reiteradamente decidido que, embora admissível, não se revela "recomendável" anular o feito naquela Corte, a partir da decisão

\footnotetext{
${ }^{330}$ Cf. TJSP, AI 9145058-37.2007.8.26.0000, Rel. Des. PEDRO BACCARAT, $7^{\text {a }}$ Câmara de Direito Privado,
} J 27/07/2011. 
que não acolheu a denunciação com a remessa dos autos à origem, a fim de não se colocarem em risco os princípios da economia e da presteza na entrega da prestação jurisdicional $^{331}$.

Em igual sentido, há uma clara tendência no Tribunal de Justiça de São Paulo de preservar, sempre que possível, os atos praticados na ação principal e evitar anulação da sentença no julgamento da apelação, mantendo-se, então, o indeferimento do pedido de denunciação da $\operatorname{lide}^{332}$. Dá-se, pois, especial relevância aos princípios da economia processual e da duração razoável do processo, evitando-se a repetição de atos e conferindo oportunidade de o denunciante ajuizar ação regressiva autônoma, cujos limites são distintos dos da ação principal, mas por meio da qual poderá alcançar, mesmo com mais atividade, o resultado almejado.

6.7. Da sentença e interesse em recorrer. A ação principal e a regressiva são julgadas conjuntamente, em uma só sentença, constituindo isso um dos grandes atrativos de economia do instituto. Dessa maneira, permite-se que duas relações jurídicas sejam objeto do mesmo processo, de uma única instrução processual e de uma única sentença.

Nesse sentido, o art. 76 do Código de Processo Civil estabelece, textualmente, que "a sentença, que julgar procedente a ação, declarará, conforme o caso, o direito do evicto, ou a responsabilidade por perdas e danos, valendo como título executivo". Evidencia-se, pois, o caráter prejudicial da primeira ação, de vez que a segunda só definirá a responsabilidade por perdas e danos se a primeira for contra o denunciante.

\footnotetext{
${ }^{331}$ Nesse sentido: "Ainda que a denunciação da lide tenha sido mal indeferida, não se justifica, na instância especial, já adiantado o estado do processo, restabelecer o procedimento legal, porque a finalidade do instituto (economia processual) seria, nesse caso, contrariada" (REsp 170.681/RJ, Rel. Min. ARI PARGENDLER, $3^{\text {a }}$ Turma, J 01/04/2008, DJ 15/04/2008). Na mesma linha: REsp 875.575/RJ, Rel. Min. CASTRO MEIRA, $2^{\text {a }}$ Turma, J 13/12/2011, DJe 17/02/2012; REsp 1.187.943/GO, Rela. Min. ELIANA CALMON, $2^{\text {a }}$ Turma, J 25/05/2010, DJU 07/06/2010; AgRg no Ag 1.190.904/SP, Rel. Min. SIDNEI BENETTI, $3^{\text {a }}$ Turma, J 27/10/2009, DJ 06/11/2009; REsp 293.118/SP, Rel. Min. SÁLVIO DE FIGUEIREDO TEIXEIRA, $4^{\mathrm{a}}$ Turma, J 13/03/2001, DJ 11/06/2001.

${ }^{332}$ Cf. AP 0006017-32.2007.8.26.0576, Rel. Des. SÁ MOREIRA DE OLIVEIRA, $33^{\text {a }}$ Câmara de Direito Privado, J 28/05/2012; AP 0210475-98.2009.8.26.0007, Rel. Des. CANDIDO ALEM, $16^{\mathrm{a}}$ Câmara de Direito Privado, J 03/04/2012; AP 0517898-23.2010.8.26.0000, Rel. Des. EDUARDO SIQUEIRA, 38ª Câmara de Direito Privado, J 08/02/2012.
} 
Inicialmente, impõe-se criticar a redação do referido dispositivo. Equivocada a expressão "declarar", sugerindo que a decisão da ação de regresso poderia ser meramente declaratória, o que, todavia, não se ajusta à previsão de que valerá como título executivo, evidenciando-se nítido caráter condenatório. Assim, o sentido deve ser de que o julgador reconhecerá o direito do evicto ou a responsabilidade por perdas e danos ${ }^{333}$.

Além disso, ignorou o legislador que a denunciação também pode ser realizada pelo autor e, da mesma maneira, terá que ser resolvida por meio de uma sentença. Assim, se a ação for julgada improcedente, a denunciação do litígio pelo autor também será decidida, não só resolvendo o direito do evicto e a responsabilidade por perdas e danos, mas também constituindo título executivo em prol do denunciante.

Inexiste, outrossim, qualquer vinculação entre o resultado da ação principal e o da regressiva, até porque se trata de duas relações jurídicas distintas. Assim sendo, ambas podem ser julgadas procedentes, no todo ou em parte, ou improcedentes; de outra forma, a ação principal pode ser julgada procedente e a lide secundária, improcedente.

Se a ação principal é julgada improcedente, na denunciação feita pelo réu, a lide secundária, por ser ação eventual e condicional ao resultado da primeira, estará fadada ao fracasso; cabe, porém, ao magistrado dirimi-la, a fim de não caracterizar-se como sentença citra petita. Deverá reconhecê-la como prejudicada, pois o denunciante não colheu o resultado que lhe daria o direito de apurar a responsabilidade do denunciado.

Além disso, como a sentença que julgará ambas as relações é única, só é admissível, em vista do princípio da unirrecorribilidade, a interposição de um só recurso; porém, em muitas situações, torna-se complexo aferir o interesse das partes e do denunciado em recorrer.

No caso de a ação ser julgada improcedente e a lide secundária restar prejudicada, ao autor, por evidente, assiste interesse em recorrer, de vez que foi vencido, mas não ao denunciado, que foi vencedor. O réu, diferentemente, foi vencedor na ação principal e vencido na ação de regresso, o que lhe possibilita apelar, à luz do art. 499 do Código de

${ }^{333}$ Cf. José Manoel de Arruda Alvim Netto, Código de processo civil comentado, p. 327/329. 
Processo Civil; no entanto, não existe interesse, no plano do binômio necessidade e utilidade recursal $^{334}$. De qualquer maneira, ressalta-se, diante da regra do $\S 3^{\circ}$, do art. 515 , do Código de Processo Civil, que o Tribunal poderá, nos casos de extinção sem julgamento do mérito - se a causa versar sobre questão exclusivamente de direito e os fatos estiverem provados - julgar a denunciação da lide, caso dê provimento ao recurso do autor. Dessa forma, se a sentença for reformanda para que se julgue procedente a ação e se estiverem presentes os pressupostos legais, caberá ao Tribunal julgar também, desde logo, a denunciação ${ }^{335}$.

Pondere-se, no entanto, que o réu e o denunciado podem possuir interesse em recorrer contra algum capítulo da sentença, como, por exemplo, a definição dos ônus sucumbenciais, de modo que, ainda que vencedores, não é possível ceifar genericamente o direito de eles apelarem.

Na hipótese de ambas as ações terem sido julgadas procedentes e a denunciação ter sido realizada pelo réu, assiste a este interesse de recorrer para postular a improcedência da ação, bem como ao denunciado para buscar a reforma da ação principal e também da lide secundária. $\mathrm{O}$ autor não terá interesse, dado que saiu vencedor relativamente a sua pretensão, a não ser que se insurja, eventualmente, contra o capítulo que tenha fixado os ônus da sucumbência ou ainda que haja alguma questão acessória, como a incidência dos juros de mora.

Caso a ação seja julgada procedente e a denunciação, improcedente, ao réu assiste interesse para atacar tanto o capítulo relativo à ação principal como o da de regresso. Falta ao autor interesse em recorrer, em razão de não reconhecermos o direito da condenação direta do denunciado e tratar-se de outra relação jurídica, que não o envolve. Além disso, apesar de não ter sido vencido, também possui interesse o denunciado, em vista de uma das funções da denunciação - como já se pontuou anteriormente - ser a de auxiliar a defesa do denunciante, evitando, ademais, que este seja vencido na principal, o que poderia lhe dar força para a ação de regresso; é lhe facultado, portanto, recorrer a fim de também ser

\footnotetext{
${ }^{334}$ Essa ideia decorre da tradicional lição de José Carlos Barbosa Moreira: "de um lado, é preciso que o recorrente possa esperar da interposição do recurso, a consecução de um resultado a que corresponde situação mais vantajosa, do ponto de vista prático, do que a emergente da decisão recorrida; de outro lado, que lhe seja necessário usar o recurso para alcançar tal vantagem" (Comentários ao Código de Processo Civil, p. 298).

${ }^{335}$ V., a propósito, Cássio Scarpinella Bueno (Partes e terceiros no processo civil brasileiro, p. 270-272).
} 
julgada improcedente a demanda promovida em face do réu ${ }^{336}$, o que o distanciaria ainda mais de responder por qualquer indenização.

\subsection{Da condenação direta do denunciado frente ao adversário do}

denunciante. Tormentosa questão relacionada ao instituto é o alcance da eficácia da sentença e a possibilidade de o denunciado ser condenado diretamente na ação principal em favor da parte contrária do denunciante.

Há divergências técnicas quanto a essa possibilidade. Antes de enfrentá-las, relevante destacar que, no plano prático, a condenação direta do denunciado é, sem dúvida alguma, vantajosa e preferível, dado que dispensa que o vencido satisfaça a execução para, após, buscar o seu direito de regresso em relação ao denunciado. Se assim for, menos atos processuais serão praticados e evitar-se-á que o denunciante tenha que cumprir a obrigação para, então, executar o denunciado, fundado em título executivo judicial, que é a sentença condenatória, nos termos dos arts. 568, I, 583 e 584, I, do texto processual. Amolda-se plenamente, portanto, aos princípios da economia e da celeridade processuais.

Outro benefício que a condenação direta do denunciado constitui é a possibilidade de a obrigação ser satisfeita, mesmo diante de eventual insolvência do denunciante, que não cumpre voluntariamente a sentença e não possui bens passíveis de penhora. Esse quadro, que impediria a extinção da execução pela satisfação ou, ao menos, retardá-la-ia com obstáculos naturais, seria facilmente contornado por meio da condenação direta do denunciado, que poderia, ao invés de aguardar comodamente o seu momento de cumprir o título executivo judicial de regresso, pagar diretamente a indenização ao vencedor da ação principal ou ter seus bens constritos. Dessa maneira, o resultado útil do processo seria prestigiado.

A condenação direta é, pois, benéfica ao adversário do denunciante - dado que, assim, ele tem maiores possibilidades de receber o que lhe é de direito - bem como ao

\footnotetext{
${ }^{336}$ Nesse sentido, o Superior Tribunal de Justiça já decidiu, in verbis: "Processual civil. Denunciação da lide. Legitimidade da denunciada para recorrer. Arts 75, I, e 509 do CPC. A denunciada/recorrente que aceita parcialmente a denunciação e contesta a inicial da ação instaurada entre o autor/recorrido e a ré/denunciante, torna-se litisconsorte desta e, como decorrência, legitimada para recorrer da sentença que julgou a lide primária de que lhe resultou uma condenação. Recurso conhecido e provido" (REsp 99.453/MG, Rel. Min. CESAR ASFOR ROCHA, $4^{\text {a }}$ Turma, J 04/08/1998, DJ 03/11/1998, p. 141).
} 
próprio denunciante, que não precisa pagar para somente após exercer o seu direito de regresso, postulando o cumprimento da sentença contra o denunciado e correndo o risco de este ser insolvente. Para o denunciado não há vantagem, de vez que o momento de satisfazer a obrigação é antecipado, mas o processo não lhe deve essa vantagem, logicamente.

Feitas essas considerações práticas, impõe-se abordar tecnicamente a questão. As disposições de direito processual não tratam, expressamente, da admissibilidade da condenação direta, estabelecendo o art. 76 do Código de Processo Civil apenas que "a sentença, que julgar procedente a ação, declarará, conforme o caso, o direito do evicto, ou a responsabilidade por perdas e danos, valendo como título executivo".

Essa admissibilidade só seria possível caso se entendesse que o denunciado assumiria efetivamente a posição de litisconsorte do denunciante. Isso posto, se a posição processual do denunciado fosse efetivamente a de litisconsorte, a partir do disposto no art. 75, I, do Código de Processo Civil, dever-se-ia admitir, por coerência, sua condenação direta.

Discordamos, todavia, dessa posição, ao entender que se trata de mera assistência ${ }^{337}$, por não existir vínculo de direito material entre o denunciado e o adversário do denunciante, conforme discorremos no capítulo 4.6. Mesmo que se reconheça uma legitimidade extraordinária ou que se adote a influência do direito germânico primitivo de substituição processual, ainda assim não é cabível a condenação direta, por força, ainda, da falta de relação de direito material.

Não é possível confundir ou intencionalmente imiscuir a denunciação da lide com o chamamento ao processo, no qual o chamado pode ser condenado juntamente com o chamante. As características dos institutos são distintas, não se tratando, no chamamento, de exercício de ação regressiva do chamante contra o chamado, até porque este nada deve para aquele, mas eventualmente apenas ao autor. Acrescente-se, ainda, que as pessoas que podem ser chamadas possuem sempre vínculo de direito material com o autor, tanto que é cabível serem diretamente por ele demandadas, ao contrário do que se dá na denunciação.

${ }^{337}$ Cuida-se de assistência simples, nas hipóteses dos incisos I e III, do art. 70, do CPC, e de assistência litisconsorcial na do inciso II, do mesmo dispositivo. 
Em vista de as particularidades dos institutos serem manifestamente distintas, não é possível tomar de empréstimo o chamamento para condenar diretamente o denunciado valendo-se de analogia - até porque a denunciação da lide não serve para ampliar o raio de legitimidade passiva.

Além disso, a denunciação da lide está intimamente ligada ao processo de conhecimento e constitui instituto que proporciona o auxílio na defesa dos interesses do denunciante pelo denunciado, bem como o ressarcimento na hipótese de aquele sucumbir na ação principal. Flagrante, pois, o limite de efetividade da denunciação da lide, que não alcança a condenação direta do denunciado. No direito brasileiro vigente - como já foi objeto de nossas considerações - a denunciação constitui um sistema híbrido, com influência do direito romano e do direito germânico primitivo, de modo que, na fase executiva, existe apenas a faculdade de o denunciante valer-se de seu direito regresso, realizando-o no mesmo feito, de modo a poupar-se de ajuizar uma ação autônoma de regresso.

A admissibilidade de condenação direta do denunciado em favor da parte adversa do denunciante, ademais, não possui raiz histórica e não se fundamenta em qualquer dispositivo legal, constituindo criação doutrinária e jurisprudencial, que buscou, na prática, criar mecanismo para conferir efetividade à tutela jurisdicional prestada. Assim sendo, a estrutura da denunciação, o alcance e a finalidade do instituto não proporcionam a condenação direta do denunciado, de maneira solidária e muito menos exclusiva.

Apesar do evidente cunho prático em que o instituto está inserido, por serem resolvidas conjuntamente a ação principal e a denunciação da lide, não há como lhe conferir interpretação extensiva e considerar que o denunciado pode ser sempre condenado diretamente só porque existe o direito de regresso. As raízes inspiradoras da denunciação da lide a tanto não chegam, embora não seja possível negar que o princípio norteador seja semelhante; o instituto não tem, contudo, esse alcance e a solidariedade não se presume nos termos do art. 265 do Código Civil.

Além disso, por força dos limites da denunciação, no caso de o denunciado ser condenado diretamente a pagar indenização ao adversário do denunciante, haverá julgamento extra petita, ferindo os termos dos arts. 128 e 460 do Código de Processo Civil, 
de vez que é defeso ao juiz proferir sentença de natureza diversa da pedida pelo autor. Considerando que o autor ajuizou ação de indenização em face do réu e este denunciou a lide ao denunciado, não é possível apegar-se ao princípio da instrumentalidade das formas e condenar o denunciado a pagar indenização diretamente ao autor.

Com efeito, o formalismo não existe por acaso e deve ser respeitado, dado que exerce papel fundamental no exercício da tutela jurisdicional, por ser a espinha dorsal do processo, traçando as regras técnicas voltadas a lhe conferir validade. Assim, não é possível ignorar a estrutura do instituto, suas características históricas e o direito posto, o que só evidencia ser descabida a condenação direta do denunciado.

Pertinentes, nesse sentido, as considerações de CÂNDIDO RANGEL DINAMARCO, ao afirmar que "a condenação disciplinada no art. 76 do Código de Processo Civil é imposta ao denunciado e concedida exclusivamente em favor do denunciante. Não se admite a condenação do denunciado em favor do autor da demanda principal, porque nenhuma demanda moveu este àquele e sequer existia qualquer relação de direito material que os interligasse (o terceiro era parte ilegítima para a demanda proposta pelo autor). Ainda que a condenação direta apresentasse vantagens, só por disposição expressa de lei ela poderia ser admitida" ${ }^{338}$.

Ressalta-se, outrossim, a correta lição de JOSÉ ROBERTO DOS SANTOS BEDAQUE, ao afirmar que, "por falta de visão adequada do fenômeno, no plano material, sustenta-se a possibilidade de, em denunciação feita pelo réu, o juiz condenar o denunciado em face do autor originário. Tal não se mostra possível, ante a total inexistência de vínculo jurídico que justifique o reconhecimento da obrigação de um em favor do outro"339.

De maneira enfática, CÁSSIO SCARPINELLA BUENO afirma que "o art. 76 do Código de Processo Civil não autoriza essa interpretação", sustentando a inviabilidade "de haver execução da sentença diretamente contra o denunciado, como se não existisse o

\footnotetext{
${ }^{338}$ Instituições de direito processual civil, n. 607, p. 411. Nesse mesmo sentido, Rodrigo Salazar, ao afirmar não ser possível "privilegiar a todo custo a efetividade processual", de vez que "a inexistência de relação jurídica entre o denunciado e o adversário do denunciante impossibilita a condenação do primeiro frente ao segundo" (Denunciação da lide, p. 102).

${ }^{339}$ Direito e processo, p. 91.
} 
denunciante", em vista de não haver qualquer relação de direito material entre o denunciado e o adversário do denunciante",340.

Na realidade, não existe um vínculo jurídico de relação sucessiva, mas apenas um nexo de subordinação entre a ação principal e a lide secundária, a revelar o descabimento da condenação direta, como comentam WILLIAM SANTOS FERREIRA e FLÁVIO CHEIM JORGE, ao concluírem que a posição processual do denunciado é de assistente simples e defenderem que "não se trata de uma interpretação tecnicista, mas sim de uma interpretação lógica e sistemática, voltada para a segurança jurídica e social que o processo deve proporcionar" ${ }^{341}$.

O adversário do denunciante nada pediu em relação ao denunciado e nem poderia, por falta de relação de direito material, de modo que, diante do princípio da congruência, não pode o juiz, mesmo diante da denunciação da lide, condenar diretamente o denunciado a pagar indenização ao adversário do denunciante. O óbice é intransponível, só podendo o denunciado ser condenado a pagar indenização em favor do denunciante pela via do regresso, a qual só é exigível após operar-se a condição consistente na prova do efetivo pagamento ao adversário do denunciante.

Embora minoritária, destaca-se que existem decisões no Superior Tribunal de Justiça que não admitem a condenação direta, por considerar não poder o denunciado substituir o denunciante - sendo a responsabilidade da lide principal unicamente deste ${ }^{342}-$ bem como não ser possível conferir "benefício de ordem não previsto em lei"343; dessa

\footnotetext{
${ }^{340}$ A denunciação da lide e o art. 456 do novo Código Civil, p. 17. No mesmo sentido, Sydney Sanches, Denunciação da lide no direito processual civil brasileiro, p. 230.

${ }^{341}$ Denunciações da lide sucessivas - possibilidade - condenação direta e exclusiva dos denunciados, $\mathrm{p}$. 311-317. Acrescente-se que criticam, corretamente, acórdão que julgou improcedente a ação e, apesar disso, considerou cabível a denunciação da lide, condenando diretamente os denunciados em favor do autor. Na realidade, a procedência da denunciação pressupõe a derrota do denunciado na ação principal.

342 “A denunciação à lide não estabelece vínculo de direito material entre a parte adversa do denunciante e o denunciado, tendo por finalidade eventual responsabilidade do denunciado perante o denunciante. Inadmissível a condenação do denunciado na lide principal" (REsp 699.090/SP, Rel. Min. PAULO MEDINA, 6 a Turma, J. 09/05/2006). No Tribunal de Justiça de São Paulo, as decisões nesse sentido também são minoritárias: AP 0185719-37.2009.8.26.0100, Rel. Des. MILTON DE CARVALHO, 7ª Câmara Direito Privado, J. 30/11/2011; AP 0240634-07.2007.8.26.0100, Rel. Des. ADHERBAL ACQUATI, 15ª Câmara de Direito Privado, J. 16/08/2011; AP 9096691-45.2008.8.26.0000, Rel. Des. FRANCISCO LOUREIRO, $4^{\mathrm{a}}$ Câmara Direito Privado, J. 29/01/2009.

${ }^{343}$ REsp 1.235.962/SP, Rel. Min. MARIA ISABEL GALLOTTI, 4 a Turma, J. 22/11/2011.
} 
forma, para "haver a indenização da denunciada, deve o denunciante comprovar o pagamento feito ao primitivo credor, autor da ação",344.

Em sentido contrário, é difundida a admissibilidade da condenação direta, fundada no pragmático entendimento de que o denunciado assume a qualidade de litisconsorte do denunciante.

A propósito, ATHOS GUSMÃO CARNEIRO sustenta, coerente com a premissa de haver formação de litisconsórcio entre denunciante e denunciado, ser admissível a condenação direta deste, ao afirmar que, "nos casos de ação regressiva por responsabilidade civil (inclusive nas demandas contra o Estado), igualmente consideramos possível ao autor executar a sentença condenatória não só contra o réu denunciante como contra o denunciado, seu litisconsorte por força da lei processual, isso naturalmente dentro dos limites da condenação na demanda regressiva" 345 .

Por considerar que a posição do denunciado é de litisconsorte do denunciante, CLITO FORNACIARI JÚNIOR sustenta nada impedir "que o reconhecimento do direito do autor da ação, se forem procedentes ação e denunciação, dê-se em relação a ambos, saindo, pois, tanto um quanto o outro condenados perante o autor da demanda originária". Acrescenta, ainda, que o art. 76 "reforça essa possibilidade à medida que se refere à formação do título executivo, sem dizer a benefício de quem, de modo que pode ser do autor originário, que foi quem reclamou a proteção processual e que fica nesse caso com duas garantias", "permitindo, sem afronta à norma, uma inegável maior efetividade à atividade jurisdicional” ${ }^{346}$.

Ressalve-se que essa solução pode afigurar-se coerente com o texto legal, desde que se aceite sua literalidade, estabelecendo que o denunciado assume a posição de litisconsorte do denunciante, com o que não concordamos: apesar de a condenação direta ser sedutora, ela não pode ser admitida como regra. Ainda que se considere haver litisconsórcio, o princípio da congruência seria desrespeitado, dado que é vedado ao juiz

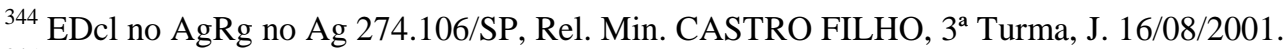

345 Intervenção de terceiros, p. 153.

346 "A condenação diante da denunciação", in Processo civil: verso e reverso, p. 40. 
decidir além ou fora do que foi pedido, não sendo possível condenar o terceiro, em relação ao qual o autor nada pediu.

MILTON FLAKS sustenta ser cabível a condenação direta, porém somente no caso de o denunciado aceitar a denunciação, ainda que parcialmente; dessa forma, sua condenação aconteceria nos limites da responsabilidade aceita e declarada. Conclui que, "embora o título executivo do autor seja a sentença condenatória proferida em face dos litisconsortes, pode-se dizer que o reconhecimento da responsabilidade do denunciado, nos termos do art. 76 do CPC, produz efeitos não só em relação ao denunciante, mas também em relação ao adversário comum",347.

Apesar de reconhecer que o rigor técnico impede a condenação direta do denunciado, GELSON AMARO DE SOUZA afirma que a formalidade deve ser abrandada para evitar que o autor fique sem receber em razão da falta de pagamento pelo réu. Diz que “o resultado será o mesmo, apenas o caminho de acesso à Justiça é que será encurtado. Altera-se apenas o procedimento, mas não se altera o direito substancial, que é o que mais importa", concluindo que, "em nome da eficácia processual e do acesso à Justiça, não se deve prender à simples formalística e prejudicar a realização do Direito" ${ }^{348}$.

Feitas essas referências doutrinárias quanto à possibilidade de condenação direta do denunciado, ponderamos que também existem disposições na legislação material conferindo-lhe amparo. Elas estão associadas à evicção e ao contrato de seguro de responsabilidade civil facultativo.

Assim, o art. 456 do Código Civil admite a denunciação per saltum, de modo que o adquirente pode denunciar a lide ao alienante imediato ou a qualquer dos anteriores, apesar da falta de vínculo jurídico de direito material. Caso não seja assim, não há qualquer lógica em só admitir o direito de regresso, desde que o alienante imediato tenha cumprido a obrigação para, somente então, pleitear o reembolso do antecessor e este do que o precedeu. Se houvesse qualquer conluio na cadeia dos alienantes ou insolvência, inócua seria a previsão legal; assim sendo, deve-se efetivamente admitir a condenação direta para buscar satisfação da obrigação de qualquer daqueles da cadeia dominial. Não se pode

\footnotetext{
${ }^{347}$ Denunciação da lide, n. 124, p. 144.

${ }^{348}$ Cumprimento de sentença diretamente contra o denunciado, p. 27-34.
} 
negar, no entanto, que essa possibilidade pode comprometer o próprio direito de defesa, de vez que o denunciado pode não conhecer o histórico completo da situação que lhe seria útil para a defesa.

Isso posto, na situação prática que provavelmente mais se aplica o instituto, a do contrato de seguro de responsabilidade civil facultativo, consideramos ser cabível a condenação direta do segurador, apesar da falta de relação jurídica, caso a ação tenha sido movida diretamente em face dele. É incoerente e ilógico permitir o ajuizamento da ação, mas afastar a possibilidade de condenação, dado que o segurador assumiria posição meramente decorativa no processo, o que, todavia, não se afinaria com o ordenamento jurídico e contrariaria a própria regra do art. 787 do Código Civil, segundo a qual "o segurador garante o pagamento de perdas e danos devidos pelo segurado a terceiro". Ora, se ele garante em favor de terceiro, é óbvio que é cabível a condenação direta, em sintonia com a própria essência do seguro, qual seja a de proteger o patrimônio do segurado no limite da apólice.

A condenação direta do segurador, contudo, só é possível se ele for demandado diretamente pela vítima do dano. Caso não o seja e o segurado denuncie a lide ao segurador, não é admissível a condenação direta do denunciado, em vista de sua posição no processo, que consideramos, como já expusemos, não ser de litisconsorte daquele. Assim, a possibilidade de condenação direta está associada, nesse caso, à regra expressa de direito material, mas não ao instituto da denunciação da lide, pois não há obrigação assumida contratualmente ou solidariedade entre o segurado e o segurador a ensejar a condenação direta.

Assim, ressalvamos nosso entendimento de que, diante do texto legal expresso de direito material, nas hipóteses de evicção em que a denunciação per saltum tenha sido deduzida e de contrato de seguro de responsabilidade civil facultativo, é possível a condenação direta do denunciado, desde que o adquirente denuncie a lide aos alienantes anteriores e a vítima do dano mova a ação diretamente em face do segurador.

Sem "defender a banalização da condenação direta, mas sim o aproveitamento das potencialidades do direito material pelo processo como forma de outorgar maior efetividade às justas expectativas dos litigantes e alcançar a justiça do caso concreto", 
DANIEL USTÁRROZ admite-a nos contratos de seguro e "em outros âmbitos, desde que respeitadas as balizas do sistema" e as garantias processuais das partes, com fundamento nos arts. 421 e 422 do Código Civil e no art. 75, I, do Código de Processo Civil ${ }^{349}$.

Diante dos frutos na prática da condenação direta do denunciado ${ }^{350}$, essa corrente é extremamente valorizada pela jurisprudência do Superior Tribunal de Justiça, que tem atenuado o formalismo e o rigor técnico para considerar que o denunciado pode ser condenado direta e solidariamente com o denunciante, porém não exclusivamente, na hipótese de ter aceitado a denunciação e contestado o pedido, por assumir a posição de litisconsorte passivo ${ }^{351}$.

Diante da multiplicidade de recursos que foram dirigidos ao Superior Tribunal de Justiça discutindo a possibilidade de condenação solidária de segurador que foi denunciado pelo segurado, causador de danos a terceiro, definiu-se que, em ação de reparação de danos, o segurador denunciado pode ser condenado direta e solidariamente com o denunciante a pagar indenização à vítima, nos limites contratados na apólice. Considerouse, em sede de recurso repetitivo ${ }^{352}$, que essa solução satisfaz não só "os anseios de um processo justo e célere", mas também o direito do segurado ao devido processo legal; confere "praticidade ao comando judicial"; possibilita o exercício do contraditório e da ampla defesa; alcança "o exato resultado desejado pelo direito material" e evita que o

\footnotetext{
${ }^{349}$ A intervenção de terceiros no processo civil brasileiro, p. 126. Ao tratar do contrato de seguro, Edson Ribas Malachini vai além, ao rebater as críticas à condenação direta do denunciado, e diz "que a inexistência de relação jurídica direta entre o autor da ação e o denunciado não impede a condenação desse a pagar àquele o valor do seguro ou do resseguro, cumprindo obrigação assumida contratualmente com o denunciante; e que a solidariedade resulta, sim, do contrato: não do contrato entre o autor e o denunciado, efetivamente inexistente, mas do próprio negócio jurídico entre denunciante e denunciado" (Seguro, resseguro, litisconsórcio e denunciação da lide, p. 42).

${ }^{350}$ Fabiano Carvalho e Rodrigo Barioni defendem que se deve aceitar a execução direta do denunciado, para "atender aos fins sociais a que a lei se destina"; "prevalecer o interesse público que existe na integral satisfação do crédito do autor e na certeza de que haverá solução definitiva dos conflitos instaurados com as demandas principal e secundária"; "encurtar o caminho da indenização"; e "elimina[r] conflitos que poderiam ser mantidos caso o autor não obtivesse êxito em receber seu crédito junto ao denunciante" (Eficácia da sentença na denunciação da lide, p. 72-74).

${ }^{351}$ Cf. AgRg no REsp 474.921/RJ, Rel. PAULO DE TARSO SANSEVERINO, $4^{\text {a }}$ Turma, J 05/10/10; REsp 1.180.261/RS, Rel. Min. NAPOLEÃO NUNES MAIA FILHO, $1^{\mathrm{a}}$ Turma, J 19/08/2010; REsp 1.010.831/RN, Rel. ALDIR PASSARINHO JÚNIOR, $4^{\text {a }}$ Turma, J 22/04/09; REsp 686.762/RS, $3^{\text {a }}$ Turma, Rel. Min. CASTRO FILHO, J 29/11/06; REsp 699.680/DF, Rel. Min. FERNANDO GONÇALVES, 4a Turma, J 29/06/06; REsp 211.119/ES, Rel. Min. JOÃO OTÁVIO DE NORONHA, 2 $2^{\text {a }}$ Turma, J 17/05/05; REsp 275.453/RS, Rel. Min. HUMBERTO GOMES DE BARROS, $3^{\text {a }}$ Turma, J 22/02/05; REsp 188.158/RS, Rel. Min. FERNANDO GONÇALVES, $4^{a}$ Turma, J 15/06/04; REsp 97.590/RS, Rel. Min. RUY ROSADO DE

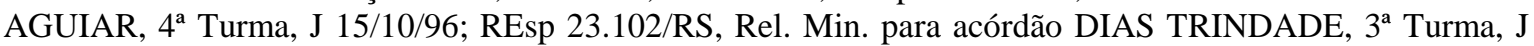
09/03/93, por maioria de votos. Também nesse sentido: TRF $4^{a}$ Região, AP 2006.71.027727-2/RS, Rela. Desa. Federal MARGA INGE BARTH TESSLER, $4^{\text {a }}$ Turma, J 10/03/10, RT 896/359.

${ }^{352}$ REsp 925.130/SP, Rel. Min. LUIS FELIPE SALOMÃO, 2 ${ }^{\mathrm{a}}$ Seção, J 08/02/12, RT 921/748.
} 
segurado obtenha "lucro com o ilícito praticado". Concluiu que, diante da flexibilização do sistema e do escopo social e público do processo, a condenação direta e solidária do segurador denunciado "é a técnica que melhor se afina com os atuais contornos dos direitos processual e material civil brasileiros".

Ressalte-se, ainda, haver posição intermediária, como a defendida por NELSON NERY JÚNIOR e ROSA MARIA DE ANDRADE NERY, que consideram não ser cabível a condenação direta do denunciado, porque ele é assistente simples do denunciante na lide principal. Admitem, no entanto, que o vencedor da ação principal execute diretamente o denunciado, na hipótese de o denunciante "condenado na ação principal, e vencedor na denunciação", não ter "condição de suportar a execução da ação principal”, operando-se a "sub-rogação do credor da ação principal nos direitos do devedor, vencedor da denunciação" 353 .

Trata-se, pois, de corrente que não admite a condenação direta, por não haver título executivo judicial que possibilite o adversário do denunciante executar diretamente o denunciado. Somente permite que este seja executado, após ser constatada a insolvência daquele, operando-se a subrrogação.

Apesar da falta de título executivo judicial, o Superior Tribunal de Justiça já reconheceu, embora não sob o regime da subrrogação, a possibilidade de o segurador ressarcir o lesado. Se "insolvente o causador do dano, o crédito do lesado reconhecido em sentença pode ser cobrado diretamente da sua seguradora, a quem fora denunciada a lide, no limite do contrato. Não é requisito para a execução do contrato de seguro para cobertura de danos resultantes de acidente de trânsito o prévio pagamento por parte do segurado, quando ficar demonstrada essa impossibilidade pela insolvência do devedor",354.

Esse entendimento, todavia, parece-nos inaceitável, em vista das particularidades da denunciação da lide. Na realidade, o denunciante teria simples direito de regresso, como se infere do disposto no inciso III, do art. 70, do Código de Processo Civil, de modo que não seria possível dar-se a subrrogação, como sustentado. Além disso, não é possível

${ }^{353}$ Código de processo civil comentado, p. 254.

${ }^{354}$ REsp 397.229/MG, Rel. Min. RUY ROSADO DE AGUIAR, 4 ${ }^{\mathrm{a}}$ Turma, J 02/05/02; AGA 247.761/DF, Rel. Min. ARI PARGENDLER, $3^{\text {a }}$ Turma, DJ 20/03/00; REsp 115.046/RS, Rel. Min. BARROS MONTEIRO, $4^{\text {a }}$ Turma, J 25/08/98. 
buscar soluções casuísticas, baseadas no sentimento de justiça, para conferir efetividade ao direito do adversário do denunciante. Haveria ostensiva ofensa à coisa julgada que se formou sobre a sentença prolatada na ação de conhecimento, em vista de, na hipótese de não ter havido condenação direta, necessário fosse que o denunciante cumprisse a obrigação para, após comprovar o pagamento à parte lesada, ser ressarcido, nos limites da lide secundária. Ele não vira devedor, mas, tendo pagado, torna-se credor (art. 346, III, co $\mathrm{CC})$.

Essa situação não se confunde com o disposto no art. 101, II, do Código de Defesa do Consumidor, dado que, se o réu for declarado falido, faculta-se à vítima que sofreu o dano ajuizar ação diretamente contra o segurador, sendo que esta pode vir a ser condenada a pagar indenização em favor daquela, justamente porque foi permitido ao autor demandá-la diretamente nessa hipótese específica. Na realidade, a denunciação da lide é inadmissível em lides de consumo (art. 88 do $\mathrm{CDC}$ ), sendo que a referida disposição consumerista trata de nova modalidade de chamamento ao processo, como expressamente disciplina o legislador, ao reportar-se ao art. 80 do texto processual e prever que o réu poderá “chamar" ao processo o segurador ${ }^{355}$.

\subsection{Da penhora dos direitos relativos ao seguro de responsabilidade civil.}

Diante da inviabilidade legal de o adversário do segurado pleitear o cumprimento da sentença diretamente contra o denunciado, tem-se aventado alternativa a essa impossibilidade, na hipótese de o executado não cumprir espontaneamente a obrigação e ter firmado contrato de seguro. Há corrente que sustenta a viabilidade de o credor pleitear a penhora dos direitos que o segurado possua em relação ao segurador, com fundamento no art. 655, XI, do Código de Processo Civil.

Em tese, não existe óbice em penhorar-se esse crédito a que o executado tem direito, de vez que o crédito de seguro pode ser enquadrado como "outros direitos" e ser, pois, penhorado ${ }^{356}$, mesmo porque não está no rol dos bens absoluta ou relativamente

\footnotetext{
${ }^{355}$ V., a propósito, Kazuo Watanabe (Código brasileiro de defesa do consumidor comentado pelos autores do anteprojeto, p. 797-798).

${ }^{356}$ V., a propósito, Gelson Amaro de Souza, Cumprimento de sentença diretamente contra o denunciado, $\mathrm{p}$. 36-37.
} 
impenhoráveis (arts. 649 e 650 do CC). Ocorre, no entanto, que este crédito do denunciante está submetido a uma condição, qual seja, a de ele pagar o que deve ao autor.

Para formalizar a constrição, o segurador deverá ser intimado, nos termos do art. 671 do texto processual, a não pagar ao seu credor e depositar o valor em conta judicial vinculada ao processo.

Embora reconheça que a proposta deva ser amadurecida e melhor examinada, URBANO RUIZ diz, ao tratar do contrato de seguro de responsabilidade civil, ser cabível a penhora do crédito a que o segurado tem direito, por força do contrato de seguro firmado, "nos limites da apólice e das regras que disciplinam o ajuste, ou seja, desde que não agrave o risco e efetivamente tenha provocado o dano, além de ter feito o pagamento do valor do prêmio avençado". Conclui que, "se não levada a efeito a denunciação, de modo a obrigar a seguradora a integrar a lide, razoável que, na execução, a penhora recaia sobre os direitos - o crédito que o devedor tem junto à seguradora"357.

No entanto, o denunciado só teria obrigação de pagar ao executado-denunciante, caso a condição se efetivasse, ou seja, se existisse a prova de o denunciante ter efetuado o pagamento ao seu adversário. A denunciação está fundada no direito de regresso, de modo que seria inócuo penhorar o crédito do denunciante, em razão de o título executivo judicial depender da prova cuja condição se verificou (art. 614, III, do CPC). Se assim fosse, mais coerente e simples seria admitir a condenação direta do denunciado, pois o adversário do denunciante praticaria menos atos executivos para alcançar, na prática, o mesmo resultado, o que se revela incoerente.

A partir do disposto no art. 757 do Código Civil também não é possível aceitar a possibilidade de penhora do crédito a que o segurado tem direito em relação ao segurador. $\mathrm{Na}$ realidade, o segurador obriga-se "a garantir interesse legítimo do segurado". Ora, o seguro é feito para resguardar o segurado das consequências patrimoniais que lhe podem advir, mas não para garantir o interesse do adversário do segurado, vítima do dano. Se o segurado executado não tiver, pelos seus motivos, interesse em satisfazer a obrigação e não pretender cumpri-la, o legislador não confere oportunidade para o adversário do segurado

${ }^{357}$ Seguro de responsabilidade civil, p. 151-152. 
exigir o cumprimento diretamente do segurador, penhorando o crédito a que o devedor teria direito.

Acrescente-se, ainda, que ao segurador deve ser garantido o direito de discutir a existência de responsabilidade do segurado, em razão da prática de ato ilícito, bem como sobre a cobertura securitária. É necessário, pois, garantir-lhe o devido processo legal, o contraditório e a ampla defesa, com os meios e recursos a ela inerentes, sem o que ninguém será privado de seus bens, nos termos do disposto nos incisos LIV e LV, do art. $5^{\circ}$, da Constituição Federal.

De qualquer modo, o segurador, como interessado na extinção da dívida, tem a faculdade de pagá-la (art. 304 do CC). Há um evidente interesse econômico em extinguir a obrigação por parte dele, a fim de evitar o agravamento da própria situação, de vez que integra a relação obrigacional, por ser indiretamente responsável pela solução do débito, detendo, pois, legitimadade jurídica para resgatá-lo.

Além disso, pondere-se que a situação é distinta, caso o denunciado, vencido na lide secundária, deposite o valor a que foi condenado, visando satisfazer a obrigação - o que não é raro ocorrer principalmente em momentos econômicos em que a rentabilidade de aplicações financeiras é inferior à correção dos débitos judiciais. Nesse caso, a condição que existia para o início do cumprimento de sentença desaparece, podendo, pois, o adversário do denunciante penhorar o valor depositado em conta judicial a que o executado tem direito.

6.10. Da denunciação da lide sucessiva e per saltum. Por primeiro, é de se destacar a evolução das regras de direito material e processual relativas à denunciação da lide sucessiva e per saltum, de vez que as novas dimensões que lhe foram dadas exigem um estudo para a compreensão das alterações implantadas.

O Código Civil de 1916 limitava o exercício do direito à garantia da evicção, ao dispor, no art. 1.116, que "para poder exercitar o direito, que da evicção lhe resulta, o adquirente notificará do litígio ao alienante, quando e como lhe determinarem as leis do processo". De maneira harmônica com o direito material, o Código de Processo Civil de 
1973, ao tratar da evicção, estabeleceu, no art. 70, inciso I, ser obrigatória a denunciação ao alienante que transmitiu o bem ao adquirente ameaçado pela evicção e, no art. 73, a denunciação ao seu antecessor, bem como facultou, de maneira sucessiva, que este denunciasse ao que o antecedeu.

A denunciação sucessiva consiste em facultar ao denunciado promover a denunciação ao seu garante ou responsável direto, que, por sua vez, pode denunciar a lide para terceiro e assim consecutivamente.

O Código Civil de 2002 inovou, ao estabelecer no art. 456 que, "para poder exercitar o direito, que da evicção lhe resulta, o adquirente notificará do litígio ao alienante imediato, ou qualquer dos anteriores, quando e como lhe determinarem as leis do processo". Ampliou, portanto, os legitimados que podem ser alcançados pelo instituto, abrangendo, inclusive, os anteriores transmitentes do bem, pouco se importando com a inexistência de vínculo jurídico entre denunciado e denunciante.

No sistema anterior ao Código Civil de 2002, a denunciação da lide só era possível contra aquele de quem o denunciante diretamente tivesse adquirido o bem. Não era cabível a denunciação da lide per saltum, por força de o art. 73 do Código de Processo Civil estabelecer, expressamente, a possibilidade de denunciação sucessiva, ao dispor que, para os fins do disposto no art. 70, o denunciado intimaria o terceiro, observando-se o disposto no art. 72 quanto aos prazos. Com isso se poderia alcançar os alienantes distantes, porém não por ato direto do demandante ou demandado.

De acordo com essa regra, poderia, antes do advento do novo Código Civil, haver apenas uma cadeia de denunciações. Àquele que foi denunciado era facultado, de maneira sucessiva e gradual, provocar a denunciação da lide ao que lhe transferiu o bem, igualmente fazendo este ao que lhe antecedeu e assim continuamente. Permitia-se a cumulação sucessiva de várias denunciações da lide no mesmo processo, mas restringia-se o instituto, em vista de não se permitir que o denunciado se voltasse contra os anteriores transmitentes do bem, com quem não havia mantido relação jurídica direta. 
No entanto, ressalva-se posição difundida por EGAS DIRCEU MONIZ DE ARAGÃO ${ }^{358}$, muito antes de o Código Civil de 2002 e de o Código de Processo Civil de 1973 entrarem em vigor, quando o instituto ainda era denominado de chamamento à autoria. Defendia esse autor ser possível denunciar a lide a todos os integrantes da cadeia dominial. Apegava-se ao objetivo da lei, qual seja, o de responsabilizar pela evicção todos os que lhe deram causa, até encontrar o culpado pelo vício. Realizava, assim, uma interpretação teleológica, embora reconhecesse que a interpretação gramatical e a evolução histórica do instituto apenas conduziam à denunciação gradual. Alertava que a denunciação coletiva era conveniente para afastar o risco da interrupção da sequência de notificações o que poderia prejudicar o denunciante - bem como para o risco de o denunciado insolvente mal intencionado não ter interesse em trazer seu antecessor, interrompendo as denunciações sucessivas ${ }^{359}$.

Levando em consideração essas limitações, antes de as inovações de direito material serem introduzidas pelo Código Civil de 2002, pondera-se, ainda no plano processual, que a interpretação literal do art. 73 não é a melhor, pois o verbo “intimar” dá a falsa noção de que o alienante, o proprietário, o possuidor indireto ou o responsável pela indenização serão apenas intimados, ou seja, cientificados da existência da ação, possibilitando que o denunciado, após terminado o processo, exerça o direito de regresso, na hipótese de sucumbir. Trata-se de mais uma incoerência do texto legal ${ }^{360}$, incorretamente ajustado à mudança dos seus traços do Código de 1939 - que lhe atribuía sentido restrito de garantia - para o de 1973, que, ao mesmo tempo, associou o ônus de assistência processual ao regresso.

Assim, necessário realizar uma interpretação sistemática, afinada com o princípio da economia processual, a fim de associar o termo intimação à citação. Desse modo,

\footnotetext{
${ }^{358}$ Sobre o chamamento à autoria, p. 31-45.

${ }^{359}$ Da mesma maneira, antes mesmo dessa inovação legal, Caio Mário da Silva Pereira também já sustentava o cabimento da denunciação simultânea de toda a cadeia de alienantes, afirmando que "nada impede que o evicto promova, desde logo, o chamamento de todos em cadeia, resguardando-se, desta sorte, da negligência de algum que deixe de fazê-lo, e não tenha por si próprio resistência econômica para suportar as consequências" (Direito civil brasileiro, v. III, n. 210, p. 86).

${ }^{360}$ Vicente Greco Filho critica com razão a utilização da expressão "intimará do litígio", ao dizer que "está empregado no texto no seu sentido histórico, qual seja o de dar conhecimento da lide, fazer a denunciação da lide, não alterando a forma de se fazer essa denunciação, que é a citação do denunciado" (Da intervenção de terceiros, p. 84).
} 
aquele que for convocado ao processo, assumirá, pois, a posição de réu, na lide secundária, e de assistente, na ação principal.

Em tese, são admissíveis sucessivas denunciações da lide, formando-se uma cadeia de denunciações, mas não é possível, por essa regra, conferir interpretação ampliativa e admitir a denunciação per saltum. Na realidade, o denunciado pode denunciar a lide a terceiro, desde que se apresente uma das hipóteses do art. 70, revelando vínculo jurídico diretamente com o terceiro, entretanto, não aos garantes do garante.

Ocorre, todavia, que pode haver restrições para sucessivas denunciações, por força da regra do art. 72 do texto processual e do tempo de duração do processo, a fím de evitar a sua eternização. Não havendo citação no prazo legal estabelecido, o processo prossegue e a denunciação fica prejudicada; porém, não impede - até porque seria manifesta incoerência - o denunciado de buscar o seu direito em futura ação regressiva.

O juiz pode, ainda, indeferir sucessivas denunciações, caso elas ocasionem demora excessiva ao regular prosseguimento do feito e prejudiquem a prestação da tutela jurisdicional. É certo que o processo não é destinado a conferir tratamento especial e privilegiado ao autor (art. 125, I, do CPC), de modo que é necessário buscar um equilíbrio, devendo o juiz sempre "velar pela rápida solução do litígio" (art. 125, II, do CPC), respeitando-se o devido processo legal. Para tanto, é dado ao juiz valer-se, por analogia, do disposto no parágrafo único, do art. 46, do Código de Processo Civil, que faculta ao juiz limitar o número de litisconsortes facultativos, nas hipóteses em que restar comprometida a rápida solução do litígio. Se assim o é com o litisconsorte facultativo, com muito mais razão deve-se dar com o denunciado.

É inegável que seria preferível, atendendo ao princípio da economia processual, resolver numa única instrução processual e sentença todas as relações jurídicas, mas isso poderia causar sacrifício demasiado e desproporcional à parte adversária do denunciante.

Com efeito, é necessário equilibrar os princípios e verificar se as denunciações sucessivas não comprometem o tempo de duração razoável do processo $^{361}$ ou se

\footnotetext{
${ }^{361}$ Nesse sentido, Vicente Greco Filho demonstra correta preocupação em se admitir a denunciação da lide de maneira ilimitada. Para demonstrar a incoerência, exemplifica situação em que inúmeros responsáveis numa 
eventualmente elas se justificam, em vista da economia processual; tal ideário é perseguido com a permissibilidade das sucessivas denunciações, pois tudo seria decidido conjuntamente, compensando-se eventual demora do processo com ganho em termos de pacificação das relações entre as pessoas.

A lei material, de outro lado, alterou parcialmente a limitação da denunciação, ao estabelecer que, nos casos de evicção, ao adquirente é permitido litigar em juízo com alguém que com ele não possua relação jurídica, podendo, inclusive, chamar mais de um alienante que se coloque em diferentes posições na cadeia de negócios. O art. 456 do Código Civil prevê a possibilidade de o adquirente denunciar a lide ao alienante imediato e a qualquer dos anteriores.

Pondera-se, no entanto, que essa possibilidade da denunciação per saltum é restrita aos casos de evicção: o referido dispositivo está no capítulo "Da evicção" e estabelece, expressamente, que o adquirente poderá valer-se dela "para poder exercitar o direito que da evicção lhe resulta". De qualquer modo, por sua natureza, a denunciação coletiva per saltum está efetivamente associada à evicção, em vista da suposição de ter havido diversas alienações viciadas, que não se ajustaram, em princípio, às hipóteses dos incisos II e III, do art. 70, do Código de Processo Civil. O possuidor direto poderá denunciar a lide ao proprietário ou possuidor indireto, inexistindo, pois, uma cadeia de antecessores, assim como sucede em relação àquele que estiver obrigado, pela lei ou pelo contrato, a indenizar o prejuízo do que perder a demanda, ressalvada a hipótese de resseguro, mesmo que com regime peculiar.

Dessa forma, em razão de o art. 73 do Código de Processo Civil não estabelecer a denunciação per saltum, mas apenas a sucessiva, e por o art. 456 do Código Civil admitir que ela venha ocorrer "quando e como lhe determinarem as leis do processo", não é possível, de qualquer maneira, excluir a denunciação sucessiva para qualquer um da cadeia dominial. O dispositivo processual reporta-se, genericamente, ao alienante, proprietário, possuidor indireto ou responsável pela indenização, não os tratando de maneira restritiva,

cadeia imensa seriam citados para integrar a lide: "numa demanda de indenização por dano decorrente de acidente de veículo, poderia ser chamado o terceiro, que o réu afirma ter também concorrido para o acidente, a fábrica que montou no carro peça defeituosa, a Prefeitura que não cuidou do calçamento, cabendo, também, à fábrica de automóvel chamar a fábrica de peças e esta, por sua vez, o fornecedor do material. E isto tudo em prejuízo da vítima, o autor primitivo, que deseja a reparação do dano e a aplicação da justiça, mas que teria de aguardar anos até a citação final de todos" (Da intervenção de terceiros, p. 90-91). 
de vez que não limita a intervenção de terceiro apenas, por exemplo, ao alienante imediato. Diante da nova regra de direito material, torna-se cabível a denunciação per saltum, nos casos de evicção, podendo ser citado o "alienante imediato ou qualquer dos anteriores", ou seja, todos aqueles que não eram legítimos titulares do direito que se convencionou transmitir.

Por não haver relação de direito material entre o denunciante e os alienantes anteriores do bem, mas apenas com aquele que o transmitiu, trata-se de legitimação anômala ou extraordinária, cuja excepcionalidade está definida na lei; sendo assim, é inegável a sua eficácia ${ }^{362}$.

A legitimação para essa excepcional denunciação coletiva dos alienantes anteriores decorre da falta de idoneidade jurídica das relações materiais que antecederam o negócio jurídico. A origem viciada do bem transmitido está comprometida, de modo que os alienantes devem assegurar eventual direito de regresso ao adquirente imediato, bem como a todos os que o sucederem, exceto se o adquirente souber que a coisa era alheia ou litigiosa (art. 457 do CC). O princípio da boa-fé objetiva e a função social do contrato (art. 421 do CC) justificam, apesar da falta de vínculo jurídico de direito material, que o adquirente do imóvel denuncie a lide não só ao que lhe alienou o bem, mas também a qualquer dos anteriores ${ }^{363}$.

Assim, o alienante deve garantir que o adquirente possa usufruir da coisa, como resultado do princípio da garantia e da boa-fé norteadora da conduta dos contratantes. Diante da transferência de um imóvel, definitiva ou temporariamente, deve-se conferir proteção relativamente a fatos anteriores à transmissão. A evicção não se funda na culpa do alienante, preponderando a boa-fé, em vista de o legislador proteger o adquirente, a fim de ele não sofrer prejuízo com a evicção e não constituir fonte de enriquecimento.

Como os contratantes devem colaborar mutuamente, por vigorarem, entre nós, os deveres da informação e da lealdade contratual, aquele que desrespeitar esses deveres e

\footnotetext{
${ }^{362}$ Cf. Humberto Theodoro Júnior, Uma novidade no campo da intervenção de terceiros no processo civil: a denunciação da lide per saltum (ação direta), p. 309.

${ }^{363}$ V., nesse sentido, Nelson Rosenvald, ao afirmar "que o adquirente foi ofendido não apenas pelo alienante, mas por todas as relações materiais antecedentes das quais não fez parte", dado que depositou "justas expectativas de origem lícita e legítima dos bens evencidos" (Código civil comentado, coord. Cezar Peluso, p. 516).
} 
expuser a risco outrem, que desconhecia o vício do negócio, deve responder pela evicção ao adquirente e a toda a cadeia dos adquirentes do imóvel, por força do viés extrínseco ou externo da função social do contrato. Cuida-se de uma agressão à ordem pública, atingindo não apenas o contratante, de vez que possui, ainda, potencial de repercussão social.

Assim, diante da previsão legal admitindo a denunciação per saltum, do princípio da boa-fé objetiva e da função social do contrato, plenamente viável é admitir a possibilidade de o denunciante, para poder exercitar com maior rapidez e efetividade o direito que da evicção lhe resulte, denunciar a lide a toda a cadeia de alienantes, desde a origem do vício.

Ressalve-se, no entanto, entendimento contrário, que considera não ser cabível a denunciação per saltum, mesmo com as mudanças da lei material. Nessa linha, FLÁVIO LUIZ YARSHELL diz que o art. 456 do Código Civil admite apenas a denunciação da lide de forma sucessiva, tanto que remete às leis de processo, concluindo criticamente que "pensar diferentemente seria imaginar que no polo passivo da denunciação (...) haveria uma espécie de litisconsórcio facultativo"364.

Não concordamos com esse raciocínio, dado que está claro que o legislador, ao reportar-se às "leis do processo", refere-se ao procedimento de notificação do alienante imediato ou de qualquer dos anteriores, deixando, corretamente, para o direito processual estabelecer sobre a citação dos denunciados ${ }^{365}$. Também não há como concluir que haveria um litisconsórcio facultativo, uma vez que a posição processual do denunciado não é esta, como desenvolvemos no capítulo 4.6.

Ainda que assim não fosse e existisse um conflito entre a norma civil e a de processo, a questão deveria ser resolvida de acordo com os princípios do direito intertemporal (art. $2^{\circ}, \S 1^{\circ}$, da LICC). É sabido que pouco importa em que Código o preceito está inserido, interessando apenas que a lei posterior revoga a anterior. Se o art. 456 do Código Civil prevê, expressamente, a denunciação per saltum, não é possível considerá-la incabível, em vista de não ser regulada processualmente, dado se admitir em

\footnotetext{
${ }^{364}$ Evicção e denunciação da lide no novo Código Civil: contribuição ao direito bancário, p. 37-38.

${ }^{365}$ Cf. Humberto Theodoro Júnior, O novo Código Civil e as regras heterotópicas de natureza processual, p. 27.
} 
norma processual anterior apenas a denunciação sucessiva (art. 73 do CPC). Assim, prevalece a regra de direito material posterior que admite que qualquer um da cadeia dominial seja denunciado, em detrimento da previsão anterior da lei de processo.

Parece-nos inadequada, de outro lado, a previsão do parágrafo único, do art. 456, do Código Civil ${ }^{366}$, ao facultar ao adquirente não contestar e deixar de recorrer, na hipótese de ser "manifesta a procedência da evicção". Ora, essa previsão legal não se afina à estrutura do instituto, ignorando que a denunciação constitui ação regressiva e eventual, dependente da ação principal. Além disso, difícil estabelecer o que representaria essa "manifesta procedência da evicção", a possibilitar que o denunciante sequer conteste a ação, por haver a condenação direta do denunciado ${ }^{367}$.

Não andou bem, pois, o legislador ao inovar em relação ao referido dispositivo, porque, sem qualquer técnica, disciplina regra processual, tratando de contestação e de recurso. Ora, se o denunciante não contestar, ele será revel na ação principal, o que pode ser decisivo para o seu desfecho, podendo o julgador considerar, ainda, que não se trata de "manifesta procedência da evicção", correndo, portanto, o risco de sucumbir na ação principal, por força da revelia, e, na secundária, por não se tratar de hipótese de procedência da evicção.

Apesar da deficiência e imprecisão da redação do dispositivo legal, não resta dúvida, de qualquer maneira, que a lei, além da inércia do denunciado, exige seja "manifesta a procedência da evicção". Existem, pois, duas condições para isso, sendo que a segunda delas é subjetiva, não podendo o adquirente pretender, de maneira imediata, obter o ressarcimento do alienante.

\footnotetext{
${ }^{366}$ V. Nelson Rosenvald, Código civil comentado, coord. Cezar Peluso, p. 516.

${ }^{367}$ Em sentido diverso, Silvio de Salvo Venosa afirma que o denunciante poderá deixar de contestar "nos casos de absoluta evidência, como no exemplo de título falsificado". Considera que essa hipótese ocorre frequentemente na prática e acrescenta que, "além de os aspectos de fato serem desconhecidos pelo adquirente, uma contestação nessa hipótese seria absolutamente inócua", concluindo que "não pode o adquirente que deixa de contestar (ou recorrer) sofrer os consectários da revelia ou contumácia se sua manifestação nos autos se limitar exclusivamente a denunciar a lide. Deve, no entanto, esclarecer ao juízo os motivos pelos quais não resiste à pretensão proposta" (Direito Civil, p. 589). Processualmente, consideramos que não se revela correta a conclusão de que o denunciante, que não contesta a ação, não deva sofrer as consequências da revelia. Não basta simplesmente "esclarecer" o que sucedeu para afastar esses efeitos, devendo, ainda que tenha dificuldade em contestar, impugnar os fatos constitutivos do direito do autor e esclarecê-los.
} 
Diante da precariedade da redação do texto legal, difícil precisar no que consiste “não atender à denunciação da lide”. Quer o legislador referir-se à revelia do denunciado, à confissão dos fatos ou ao reconhecimento jurídico do pedido? O dispositivo permite diversas interpretações, mas é certo que elas se afastam das hipóteses dos incisos II e III, do art. 75, do Código de Processo Civil, que estabelecem, respectivamente, que "cumprirá ao denunciante prosseguir na defesa até final" e "poderá o denunciante prosseguir na defesa", de vez que o parágrafo único, do art. 456, do Código Civil prevê que pode "deixar de oferecer contestação, ou usar de recursos", não prosseguindo, portanto, na defesa até o final $^{368}$.

6.11. Da fixação dos ônus sucumbenciais na lide secundária. A questão dos ônus da sucumbência também merece ser abordada, em decorrência da falta de norma específica sobre a questão e da complexidade proveniente das várias relações jurídicas. $\mathrm{O}$ desfecho da ação principal tem repercussão direta na lide secundária, o que dificulta, na prática forense, a fixação dos ônus sucumbenciais da denunciação, justificando a aplicação da matéria com maior atenção.

A sentença que resolver a ação principal e a denunciação da lide conjuntamente (art. 76 do CPC) deve também tratar das verbas sucumbenciais das duas ações, fazendo-o de maneira separada. Obviamente, o vencido na ação principal deverá ser condenado a pagar custas, despesas e honorários - estes fixados de conformidade com a natureza da sentença - ao vencedor, sem maiores indagações; a questão, porém, requer maior cuidado no que tange à lide secundária.

É de se ter presente, de qualquer modo, que, caso o denunciante seja derrotado na ação principal e seja vencedor na lide secundária, ele será condenado a pagar as verbas sucumbenciais ao autor, mas o denunciado deverá reembolsá-lo, inclusive dessas verbas, salvo limitação legal ou contratual. Se o direito da evicção ou do regresso incluir todos os

\footnotetext{
${ }^{368}$ Cássio Scarpinella Bueno vai além, ao concluir que "o resultado da nova regra da lei civil é que a ação seja julgada procedente diretamente contra quem, em última análise, ensejou a evicção", apesar da inexistência de relação jurídica (Partes e terceiros no processo civil brasileiro, p. 255).
} 
prejuízos causados ao denunciante, as custas e os honorários devidos na ação principal também fazem parte dos danos, valendo como título executivo judicial ${ }^{369}$.

Isso posto e de acordo com a regra do art. 20 do Código de Processo Civil, que consagra o princípio da sucumbência, dizendo que "a sentença condenará o vencido a pagar ao vencedor as despesas que antecipou e os honorários advocatícios", terá que ser definida a responsabilidade pelas custas, despesas e honorários da ação secundária.

Assim, o denunciado será condenado a pagar custas, despesas processuais e honorários advocatícios, caso a lide secundária seja julgada procedente; caso seja julgada improcedente, o denunciante será condenado a suportá-las, independentemente do resultado da ação principal.

A improcedência da denunciação faz com que os honorários desta sejam fixados por equidade, de acordo com o $\S 4^{\circ}$, do art. 20; a procedência gerará uma sentença condenatória, de modo que os honorários deverão ser fixados entre dez e vinte por cento sobre o valor da condenação, conforme o $\S 3^{\circ}$.

Se o denunciante e o denunciado forem em parte vencedores e vencidos, as despesas e os honorários deverão ser recíproca e proporcionalmente distribuídos e compensados (art. 21 do CPC). Essa previsão aplica-se às hipóteses em que a denunciação da lide é julgada parcialmente procedente, ficando cada qual, portanto, parcialmente vencido.

Ocorre, no entanto, que a questão não é tão simples quanto parece, a partir da aplicação da regra geral, oferecendo embaraços. A essência da definição das verbas sucumbenciais é a mesma de qualquer ação, mas ela pode tornar-se mais tormentosa, considerando-se elementos que são corriqueiramente debatidos na lide secundária. A partir dos princípios da sucumbência e da causalidade, bem como da regra do art. 20 do texto processual, trataremos da definição das verbas sucumbenciais na denunciação da lide facultativa e na obrigatória, bem como abordaremos a questão da não resistência do denunciado.

${ }^{369}$ Cf. Celso Agrícola Barbi, Comentários ao Código de Processo Civil, p. 355-356; Sidney Sanches, Denunciação da lide no direito processual civil brasileiro, p. 234. 
Nas hipóteses em que a denunciação da lide é facultativa, as despesas processuais e os honorários advocatícios da demanda secundária devem ser suportados pelo réu denunciante, se a ação principal for julgada improcedente ou declarada extinta sem julgamento de mérito, hipótese em que resta prejudicada a ação secundária. $\mathrm{O}$ mesmo ocorre se a ação principal for julgada procedente e a denunciação, improcedente, ou se esta for declarada extinta, sem julgamento de mérito.

Isso decorre da circunstância de a denunciação não ser obrigatória e de o denunciante ter dado causa à ação regressiva, por vontade e interesse próprios. Ao pleitear espontaneamente a intervenção de terceiro, assumiu o denunciante os riscos inerentes a toda ação judicial, devendo, pois, suportar o pagamento dessas verbas, por não ter aguardado o desfecho da ação principal para exercitar oportunamente seu direito de regresso em ação autônoma, se fosse o caso. Em vista disso, os ônus consequentes devem ser-lhe atribuídos, por ter cumulado a demanda regressiva, não podendo impor ao seu adversário da ação principal o pagamento das custas e dos honorários, até porque este não possui qualquer relação com o denunciante e não deu causa ao ingresso do denunciado no feito.

Nesse sentido, há sedimentada jurisprudência do Superior Tribunal de Justiça, condenando sempre o denunciante ao pagamento dos encargos processuais relativos à denunciação, por haver dado causa - em que pese inexista dispositivo obrigando-o a tanto e não envolva a perda do direito de regresso - aplicando-se o princípio da causalidade ${ }^{370}$.

A propósito, SYDNEY SANCHES é enfático ao afastar a responsabilidade do denunciado, uma vez que ele "não foi vencido na ação incidental", enquanto que o adversário do denunciante "não foi quem propôs a ação incidental, que ficou prejudicada".

\footnotetext{
370 Nesse sentido: "Agravo interno. Agravo de instrumento. Denunciação da lide. Honorários sucumbenciais. Nos casos como o presente, em que não é obrigatória a denunciação, o denunciante à lide, mesmo tendo sido vencedor na ação principal, deve arcar com os honorários advocatícios devidos ao denunciado e com as custas processuais relativas à lide secundária. Precedentes. Agravo improvido" (AgRg nos EDcl no Ag 550.764/RJ, Rel. Min. CASTRO FILHO, 3 Turma, J 28/06/2006, DJ 11/09/2006)". Nessa mesma linha: AgRg no REsp 1.126.178/GO, Rel. Min. CASTRO MEIRA, $2^{\mathrm{a}}$ Turma, J 03/09/2009, DJe 22/09/2009; REsp 36.135/RS, Rel. Min. ALDIR PASSARINHO JUNIOR, J 07/03/2002, DJU 15.04.02; REsp 132.026/SP, Rel. Min. BARROS MONTEIRO, 4a Turma, J 03/08/2000, DJe 02/10/2000; REsp

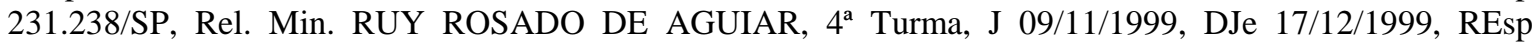

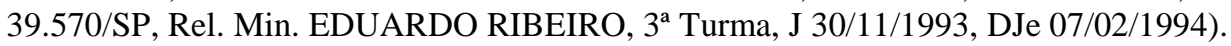


Por exclusão, atribui a responsabilidade ao denunciante por ter provocado a denunciação inutilmente $\mathrm{e}^{371}$.

A questão dos ônus sucumbenciais deve receber outro enfoque, no entanto, caso a denunciação seja obrigatória.

Dessa forma, no caso de a ação ser julgada improcedente e a denunciação de cunho obrigatório restar prejudicada, incumbe ao autor o pagamento das verbas sucumbenciais, inclusive da lide secundária, apesar de não a ter promovido e de não manter qualquer relação jurídica com o denunciado. Não se afigura razoável impor esse ônus ao réu denunciante, dado que ele não possuía alternativa - por tratar-se de denunciação obrigatória - para assegurar-se contra o causador da evicção e evitar a perda do seu direito e a recomposição do seu patrimônio ${ }^{372}$.

Consideramos ser essa solução mais correta, dado que o réu, diante da natureza da ação, dos riscos de ser vencido na ação principal e de a denunciação ser obrigatória, teve que se valer do instituto e não pode ser penalizado por tê-lo feito, mesmo na hipótese em que a ação tenha sido julgada improcedente. Apesar da autonomia da denunciação, seria absurdo cogitar, nesse caso, que ele deveria sopesar os riscos da demanda e assumilos sozinho, prescindindo do alienante. Na realidade, o autor deu causa também, ainda que indiretamente, à instauração da denunciação, devendo suportar, por inteiro, o pagamento das verbas sucumbenciais ${ }^{373}$, já que o insucesso da lide principal impediu a apreciação da modalidade dessa intervenção de terceiro.

Acrescente-se, outrossim, que o denunciado pode ter tido atuação ativa e decisiva, ao auxiliar a defesa do denunciante, reforçando essa conclusão. Desse modo, apesar do resultado da lide secundária, não se aplica, no caso, o critério da sucumbência,

\footnotetext{
${ }^{371}$ Denunciação da lide no direito processual civil brasileiro, p. 235.

372 Também nesse sentido, Cássio Scarpinella Bueno diz que caberá ao "adversário [do denunciante] responder pelas verbas de sucumbência também da denunciação. Isto porque, em última análise, foi ele quem motivou o comportamento a ser adotado pelo denunciante" (Partes e terceiros no processo civil brasileiro, $\mathrm{p}$. 269).

${ }^{373}$ Essa é a posição de José Manoel de Arruda Alvim Netto, ao afirmar que, se a denunciação da lide for julgada prejudicada e "tiver por fundamento o art. 70, inc. I, as despesas deverão ser pagas pelo adversário do denunciante na ação principal, pois foi ele quem deu causa à propositura da denunciação" (Comentários ao código de processo civil, nota 3 ao art. 76 do CPC, p. 142-143).
} 
mas o princípio da causalidade, que o engloba, pois teve que denunciar a lide por ela ser obrigatória.

Caso a ação e a denunciação sejam julgadas procedentes, aplica-se a regra do art. 20 do Código de Processo Civil, tornando-se indiferente o caráter obrigatório para a definição dessas verbas. Atribui-se o pagamento dos ônus sucumbenciais aos vencidos da lide principal e da denunciação em favor dos respectivos vencedores.

Na hipótese de a ação ser julgada procedente e a denunciação, improcedente, o réu denunciante deverá ser condenado, por ser vencido em ambas as lides, ao pagamento das custas e dos honorários dos advogados dos vencedores. Esse desfecho é decorrência do princípio da sucumbência e não se altera, mesmo em se tratando de denunciação obrigatória. Não existe fundamento para aplicar o princípio da causalidade, pois o autor foi vencedor e o réu denunciante assumiu o risco de sucumbir, ao denunciar a lide.

Se assim não fosse, geraria enorme insegurança e os réus poderiam chamar o denunciado sempre que houvesse hipótese de denunciação obrigatória, pois não sofreriam os ônus da sucumbência. Além disso, deixaria o autor em situação, no mínimo, desconfortável e fragilizada, desestimulando até mesmo ações em que o réu pudesse valerse da denunciação da lide obrigatória, de vez que correria o risco de, caso fosse vencido, ter que suportar os ônus da sucumbência da ação principal e os da denunciação.

Por fim, consideramos que, para a fixação das verbas sucumbenciais, a questão não pode ser vista sob o prisma da resistência do denunciado, por ser irrelevante a postura por ele assumida. Pouco importa se ele resistiu ou aceitou a denunciação da lide, já que a regra geral da distribuição do ônus da sucumbência está associada ao resultado do processo. Nesse caso, é possível, ademais, aplicar o princípio da causalidade, sendo indiferente eventual resistência ou não.

Caso a falta de resistência fosse relevante para a definição das verbas sucumbenciais, é certo que o fundamento também deveria ter importância nas hipóteses de revelia, o que, todavia, não ocorre. Se o revel restar vencido, ele será condenado a pagar custas, despesas e honorários advocatícios, mesmo não tendo resistido. 
Esse raciocínio faz ainda mais sentido, diante do reconhecimento jurídico do feito. A regra do art. 26 do Código de Processo Civil é expressa, ao estabelecer que aquele que reconheceu o pedido deverá pagar as despesas e os honorários advocatícios. Por que o denunciado que não apresentou resistência deve receber tratamento distinto e privilegiado relativamente ao que reconheceu juridicamente o pedido, que também não resistiu e, mais do que isso, aceitou o pedido do autor? Na realidade, o denunciado, que não resistiu, reconheceu implicitamente o direito regressivo do denunciante, de modo que se justifica, por analogia, aplicar a mesma regra e responsabilizá-lo pelas despesas e honorários advocatícios.

A única distinção em termos de postura que o legislador fez foi relativamente à ação monitória, incentivando o réu a pagar ou entregar a coisa no prazo de quinze dias para ficar isento do pagamento de custas e honorários advocatícios (art. 1.102c, $\S 1^{\circ}$, do CPC). Sequer na execução extrajudicial o devedor que paga o débito executado fica dispensado do pagamento das custas e dos honorários advocatícios (art. 20, $4^{\circ}$, do CPC), sendo que a verba honorária será, no máximo, reduzida pela metade, no caso de integral pagamento no prazo de três dias (art. 652-A, parágrafo único, do CPC). São exceções à regra geral a serem interpretadas restritivamente.

Dessa forma, ressalva-se a existência de jurisprudência ${ }^{374}$ e doutrina ${ }^{375}$ no sentido de afastar a condenação do denunciado ao pagamento das verbas sucumbenciais, nas hipóteses em que não houver resistência. Consideramos, no entanto, equivocado o critério eleito, dado que o denunciante teve que se valer da denunciação para obter auxílio na defesa dos seus interesses e resguardar-se do sucumbimento. Assim, o princípio da causalidade torna indiferente a eventual ausência de resistência do denunciado, seja a denunciação decorrente da evicção ou do direito de regresso.

\footnotetext{
${ }^{374}$ A jurisprudência do Superior Tribunal de Justiça assentou-se "no sentido de que, não havendo resistência pela litisdenunciada que se posiciona como litisconsorte da denunciante, não cabe a condenação daquela nos ônus da sucumbência pela lide secundária" (Cf. REsp 285.723/RS, Rel. para Acórdão Ministro ARI PARGENDLER, $3^{\text {a }}$ Turma, J 12/11/2001, DJ 08/04/2002, por maioria de votos; REsp 120.719/SP, Rel. Min. RUY ROSADO DE AGUIAR, 4a Turma, J 22/10/1997, DJ 12/04/1999; REsp 530.744/RO, Rel. Min. SALVIO DE FIGUEIREDO TEIXERA, 4ª Turma, J 19/08/2003, DJ 29/09/2093; REsp 91.642/RJ, Rel. Min. EDUARDO RIBEIRO, $3^{\text {a }}$ Turma, J 10/06/1996, DJ 19/08/1996).

${ }^{375}$ Clarissa Diniz Guedes e Raquel Bellini de Oliveira Salles entendem que, caso o denunciado não oponha resistência, não haverá lide e, logo, resistência que possa ensejar condenação do denunciante ao pagamento das verbas sucumbenciais, já que o denunciado se coloca na condição de seu assistente ( $A$ relação de regresso e a denunciação da lide prejudicada: da não imposição de ônus sucumbenciais ao denunciante, $\mathrm{p}$. 175).
} 


\title{
7. DA DENUNCIAÇÃO DA LIDE NO PROJETO DO NOVO CÓDIGO DE PROCESSO CIVIL
}

\author{
7.1. Da intervenção de terceiros. No capítulo da intervenção de terceiros, o \\ projeto do novo Código de Processo Civil ${ }^{376}$ alterou profundamente o sistema regulado no
}

\footnotetext{
376 O capítulo da intervenção de terceiros do projeto do novo Código de Processo Civil (Projeto de Lei do Senado n. 166 de 2010) está assim estabelecido: CAPÍTULO V - DA INTERVENÇÃO DE TERCEIROS
}

Seção I - Do amicus curiae

Art. 320. O juiz ou o relator, considerando a relevância da matéria, a especificidade do tema objeto da demanda ou a repercussão social da lide, poderá, por despacho irrecorrível, de ofício ou a requerimento das partes, solicitar ou admitir a manifestação de pessoa natural, órgão ou entidade especializada, no prazo de dez dias da sua intimação.

Parágrafo único. A intervenção de que trata o caput não importa alteração de competência, nem autoriza a interposição de recursos.

Seção II - Da assistência

Art. 321. Pendendo uma causa entre duas ou mais pessoas, o terceiro juridicamente interessado em que a sentença seja favorável a uma delas poderá intervir no processo para assisti-la.

Parágrafo único. A assistência tem lugar em qualquer dos tipos de procedimento e em todos os graus da jurisdição, recebendo o assistente o processo no estado em que se encontra.

Art. 322. Não havendo impugnação dentro de cinco dias, o pedido do assistente será deferido. Se qualquer das partes alegar, no entanto, que falta interesse jurídico ao assistente para intervir a bem do assistido, o juiz admitirá a produção de provas e decidirá o incidente, nos próprios autos e sem suspensão do processo.

Parágrafo único. Da decisão caberá agravo de instrumento.

Art. 323. O assistente atuará como auxiliar da parte principal, exercerá os mesmos poderes e sujeitar-se-á aos mesmos ônus processuais que o assistido.

Parágrafo único. Sendo revel o assistido, o assistente será considerado seu gestor de negócios.

Art. 324. A assistência não obsta a que a parte principal reconheça a procedência do pedido, desista da ação ou transija sobre direitos controvertidos, casos em que, terminando o processo, cessa a intervenção do assistente.

Art. 325. Considera-se litisconsorte da parte principal o assistente toda vez que a sentença influir na relação jurídica entre ele e o adversário do assistido.

Parágrafo único. Aplica-se ao assistente litisconsorcial, quanto ao pedido de intervenção, sua impugnação e o julgamento do incidente, o disposto no art. 322.

Art. 326. Transitada em julgado a sentença, na causa em que interveio o assistente, este não poderá, em processo posterior, questionar a decisão, salvo se alegar e provar que:

I - pelo estado em que recebera o processo ou pelas declarações e atos do assistido, fora impedido de produzir provas suscetíveis de influir na sentença;

II - desconhecia a existência de alegações ou de provas de que o assistido, por dolo ou culpa, não se valeu.

Seção III - Do chamamento

Art. 327. É admissível o chamamento ao processo, requerido pelo réu:

I - do afiançado, na ação em que o fiador for réu;

II - dos demais fiadores, na ação proposta contra um ou alguns deles;

III - dos demais devedores solidários, quando o credor exigir de um ou de alguns o pagamento da dívida comum. 
Código de Processo de Civil de 1973, dividindo-o em três seções: "Do amicus curiae", "Da assistência" e "Do chamamento". Comparando essa divisão com a do Código de Processo Civil de 1973, verifica-se que das seções existentes foram eliminadas "Da oposição", "Da nomeação à autoria" e "Da denunciação da lide", conservando-se somente o que seria a seção do "Do chamamento ao processo", mas denominando-a de "Do chamamento", na qual estão compreendidas as regras sobre o que constituem atualmente o chamamento ao processo e a denunciação da lide.

Entre as figuras de intervenção de terceiros positivadas pelo legislador de 1973, a oposição e a nomeação à autoria foram extintas; o chamamento ao processo foi mantido; e a denunciação da lide, além de ter alterada sua denominação, foi restrita tanto no que tange ao cabimento quanto no que toca ao procedimento, que recebeu novos contornos. Reconheceu-se a assistência como modalidade de intervenção de terceiros e regulou-se, no mesmo capítulo, o amicus curiae.

Não nos parece razoável, muito menos científico, eliminar os tradicionais institutos da oposição e da nomeação à autoria, simplesmente porque a incidência deles é, na prática, menor do que a de outras modalidades. Não há dúvida de que eles revelam um grau de desenvolvimento técnico respeitado e têm importante aplicação em determinadas situações específicas, servindo bem à economia processual e também à efetividade do processo. Inexiste, outrossim, entre as figuras reguladas, alguma que se revele apta a substituí-los com igual presteza. Também se mostra frágil o fundamento de simplificação do procedimento, dado que esses institutos servem justamente para conferir efetividade ao processo.

Art. 328. A citação do chamado será feita no prazo de dois meses, suspendendo-se o processo; findo o prazo sem que se efetive a citação, o chamamento será tornado sem efeito.

Art. 329. A sentença de procedência condenará todos os coobrigados, valendo como título executivo em favor do que pagar a dívida para exigi-la do devedor principal ou dos codevedores a quota que tocar a cada um.

Art. 330. Também é admissível o chamamento em garantia, promovido por qualquer das partes:

I - do alienante, na ação em que é reivindicada coisa cujo domínio foi por este transferido à parte;

II - daquele que estiver obrigado por lei ou por contrato a indenizar, em ação regressiva, o prejuízo da parte vencida.

Art. 331. A citação do chamado em garantia será requerida pelo autor, em conjunto com a do réu ou por este no prazo da contestação, devendo ser realizada na forma e prazo do art. 328.

Parágrafo único. O chamado, comparecendo, poderá chamar o terceiro que, relativamente a ele, encontrar-se em qualquer das situações do art. 330 .

Art. 332. A sentença que julgar procedente a ação decidirá também sobre a responsabilidade do chamado. 
Conforme abordamos no capítulo 3.3., a oposição é uma modalidade facultativa de intervenção, permitindo que terceiro postule o bem da vida em disputa e que o juiz decida tudo em uma mesma sentença. A oposição está em harmonia com princípios processuais valorizados pelo legislador, em razão do que não é coerente eliminar esse histórico instituto do sistema.

Do mesmo modo se passa relativamente à nomeação à autoria. Se excluído o instituto, não será possível corrigir o polo passivo, nos casos atualmente previstos no Código. Caso o projeto seja aprovado dessa maneira e o autor equivocar-se ao trazer pessoa que não seja legitimada para responder o pedido do autor ou tiver dificuldade em identificar o réu, a ação estará fadada ao insucesso, por força da ilegitimidade passiva. Deverá o demandante, então, diante do sucumbimento, promover outra ação em face do efetivamente legitimado, criando um intervalo de tempo durante o qual o conflito permanecerá. Apesar da simplicidade do procedimento para substituir o réu sem maiores transtornos, elimina-se essa alternativa, o que também não se revela positivo.

Quanto ao amicus curiae, o projeto inovou, permitindo ao magistrado chamá-lo, a seu critério (art. 320), agindo de ofício ${ }^{377}$ ou por provocação da parte. Tal pode ocorrer devido à relevância da especificidade ou à repercussão social do tema objeto da demanda. Entendemos benéfico prevê-lo no texto processual, pois é uma viva realidade, embora sem disposição legal que o regulamente. É extremamente útil que o magistrado possa chamá-lo para colaborar na compreensão de questões de alta relevância social e política, o que, se bem empregado, será benéfico para a prestação da tutela jurisdicional.

Discordamos, todavia, de considerá-lo como modalidade de intervenção de terceiro, de vez que, como abordamos no capítulo 2.5., ele não tem interesse jurídico na solução do feito e não está sujeito aos efeitos da coisa julgada. Além disso, o amicus curiae defenderá interesse institucional, ao contrário das demais figuras, em que a intervenção objetiva auxiliar uma das partes ou defender interesse próprio.

\footnotetext{
377 A redação do projeto prevê, outrossim, que o juiz pode admitir de ofício a intervenção da entidade especializada, solicitando a manifestação do amicus curiae. Isso, todavia, desfigura a essência da intervenção de terceiros no sistema pátrio, em vista de só ser cabível a intervenção espontânea do terceiro ou a provocada por uma das partes.
} 
$\mathrm{Na}$ realidade, seria melhor permitir e disciplinar o amicus curiae como se fosse um perito ou uma testemunha qualificada e admitir fosse chamado, por força de seu conhecimento técnico, mas não como uma figura de intervenção de terceiros ${ }^{378}$. Seu objetivo é emprestar seu conhecimento em questões inusitadas e ampliar a discussão antes da decisão dos juízes, estando sua atuação mais ligada ao convencimento do julgador, razão pela qual também é conhecido como "amigo da Corte" ou "amigo do juiz".

A evidenciar seu desinteresse direto na demanda, o art. 320 do projeto estabelece, ainda, ser irrecorrível o despacho que admitir o amicus curiae, quiçá a redação do dispositivo tenha reforçado a irrecorribilidade, tratando a decisão de despacho. De qualquer modo, como a intervenção do amicus curiae não é apta, em tese, a causar prejuízo às partes, parece-nos correta, nessa parte, a previsão legal ${ }^{379}$, pois falece interesse necessidade e utilidade - para a interposição de recurso. No caso de ser indeferido o pedido de uma das partes para a intervenção ser admitida, consideramos cabível a interposição de agravo de instrumento, de vez que a previsão da irrecorribilidade está claramente associada à intervenção e a norma que limita a interposição de recurso deve ser interpretada restritivamente, pois é anomalia do sistema.

Além disso, também não consideramos tecnicamente correto transferir a assistência do capítulo "Do litisconsórcio e da assistência", onde se encontra no atual Código de Processo Civil, para o da "Intervenção de terceiros", pelas razões que externamos no capítulo 3.2.2., dado que o assistente não defende interesse próprio, mas apenas auxilia o assistido para que ele seja vitorioso na demanda.

No mais, o projeto mantém a estrutura e o processamento da assistência (art. 321 a 326), realizando mínimas modificações de redação com relação ao texto atual.

\footnotetext{
${ }^{378}$ Cássio Scarpinella Bueno sustenta que "o amicus agirá no plano da instrução, no plano da formação da cognição judicial, buscando convencer o magistrado". Equipara-o, em razão disso, ao perito, à testemunha ou à prova atípica, explicando que ele "não é ' $o$ ' perito, mas, no máximo, 'um' perito. E não será ' $a$ ' testemunha ou ' $a$ ' prova atípica. Será, no máximo, 'uma' testemunha - e, mesmo assim, testemunha sui generis - ou 'uma' prova atípica” (Amicus Curiae no Processo Civil Brasileiro: um terceiro enigmático, p. 435).

${ }^{379}$ Apesar de nos parecer correta essa previsão num primeiro momento, ponderamos que se deve ter cautela, a fim de evitar abusos e exigir que os despachos sejam devidamente fundamentados, apontando-se para a presença dos requisitos que ensejam a admissão da entidade. Além disso, só se justifica a admissão de órgãos efetivamente especializados sobre a matéria objeto da demanda para que não seja desvirtuada a aplicação do instituto, o que não poderá também retardar em demasia a prestação da tutela jurisdicional. De qualquer maneira, não é possível vincular a decisão final à manifestação da entidade especializada, mesmo porque poderão intervir várias entidades que tenham posições diametralmente opostas, cabendo às partes impugnar as que sejam prejudiciais aos seus interesses e convencer o julgador que o direito lhe assiste.
} 
Acrescenta, apenas, previsão no sentido de que da decisão deferindo ou indeferindo o pedido de assistência caberá agravo de instrumento, o que nos parece correto, afastando-se, outrossim, da tendência do projeto de tornar as decisões irrecorríveis.

O chamamento ao processo é a única modalidade de intervenção de terceiro - em relação àquelas de que cuida o Código atual - que é prestigiada pelo projeto. As regras reguladoras do instituto estão sendo mantidas (art. 327 a 329), ampliando-se, porém, o prazo para o chamado ser citado, o que se revela positivo e coerente com a realidade do Judiciário.

7.2. Da denunciação da lide (chamamento em garantia). A denunciação da lide, que pelo projeto passa a se denominar chamamento em garantia, vem disciplinada juntamente com o chamamento ao processo na mesma seção, o que implica a uniformização do procedimento de ambos os institutos.

Além disso, suprime a previsão de a denunciação da lide ser obrigatória; extingue a hipótese de denunciação do inciso II, do art. 70, do Código de Processo Civil; amplia o tempo de suspensão do processo para viabilizar a citação do denunciado; e elimina a disciplina das consequências que advêm das possíveis atitudes do denunciado, como está nos arts. 74 e 75 do texto processual.

Por primeiro, a alteração da denominação do instituto é positiva, dado que a denunciação da lide, a partir de suas características no sistema brasileiro vigente e as decorrentes dessa reforma, mantém influência do direito romano e do direito germânico primitivo, de modo que constitui oportunidade de o denunciado defender-se e, ao mesmo tempo, postular seu direito de regresso. Atendeu, quanto à denominação, às consistentes críticas da doutrina.

Consideramos negativas as mudanças do projeto, no entanto, ao tratar o chamamento ao processo e o chamamento em garantia na mesma seção. Isso certamente se deve à confusão dos operadores do direito quanto ao regime jurídico de cada qual dos institutos, como se fossem modalidades de intervenção idênticas, apenas prevendo hipóteses distintas para aplicar um e outro, fazendo vistas grossas para as distinções entre 
eles $^{380}$. Essa mescla não pode ser, logicamente, considerada técnica e positiva, deixando de caracterizá-los com institutos independentes e com características próprias, sem que haja uma disciplina que bem os demarque ${ }^{381}$.

Apesar de ambos os institutos possibilitarem o direito de regresso, há expressivas diferenças exigindo que eles sejam tratados separadamente. No chamamento, existe um único vínculo jurídico entre as partes e o chamado, diferentemente do que ocorre na denunciação, em que o denunciado não possui relação jurídica com o adversário do denunciante. Em vista dessa particularidade, a responsabilidade do denunciado é secundária, enquanto a do chamado é solidária ${ }^{382}$.

Quanto à obrigatoriedade ou não de denunciar a lide, estabelece-se, no projeto, que "também é admissível o chamamento" e afastou-se, corretamente, a confusão causada pela palavra "obrigatória" do caput do atual art. 70. Essa mudança, como exposto no capítulo 4.5. deste estudo, não altera as perspectivas abordadas, pois o denunciante deve denunciar a lide, caso pretenda garantir seu direito ao ressarcimento no mesmo processo, em vista do risco de sucumbir na ação principal. Se não denunciar, arcará com os ônus processuais decorrentes e perderá o direito de regresso, na evicção - por força da regra de direito material ${ }^{383}$ - enquanto que aquele que deixar de denunciar, em que pese tenha obrigação por lei ou por contrato, não perderá esse direito.

\footnotetext{
${ }^{380}$ Eduardo de Avelar Lamy, ao tratar do princípio da fungibilidade da figura da intervenção de terceiros, afirma que, em algumas hipóteses, "a dúvida na escolha entre a denunciação da lide e o chamamento ao processo passou a ser compreensível e objetivamente verificável, especialmente junto à jurisprudência, já que a denunciação ganhou a característica da responsabilização direta, comum ao chamamento - embora utilizada em situações sem solidariedade, nas quais este, em tese, não seria cabível - ensejando a aplicação da norma da fungibilidade entre as referidas formas de intervenção de terceiros" (Intervenção de terceiros e o princípio da fungibilidade: hipóteses de aplicação, p. 197). Essa confusão entre as figuras decorre da falta de rigor científico para aplicá-las, havendo nefasta tendência de crucificar o processo civil como vilão da prestação da tutela jurisdicional e de ignorar os verdadeiros entraves ao andamento dos feitos.

381 As mudanças propostas chocam, ainda mais, diante do avanço que o instituto recebeu no Código de Processo Civil de 1973, conforme destacado por Aroldo Plínio Gonçalves (Da denunciação da lide, p. 170).

${ }^{382}$ Cf. Humberto Theodoro Júnior que, ao tratar da distinção entre os institutos, diz que a diferença "reside em que na litisdenunciação, o terceiro não tem vínculo ou ligação alguma com a parte contrária da ação principal. Só há relação jurídica entre o terceiro e uma das partes, ou seja, o denunciante. Já no chamamento ao processo, todas as pessoas mencionadas no art. 77 têm uma obrigação perante a parte contrária que o chama (ou seja, perante o autor). O devedor solidário, o afiançado, o co-fiador, todos, além da ligação ao réu, têm igualmente, perante o direito substancial, um nexo obrigacional com o autor" (Intervenção de terceiros no processo civil: denunciação da lide e chamamento ao processo, p. 55).

${ }^{383}$ Cândido Rangel Dinamarco afirma que "a perda do eventual direito subjetivo material perante o terceiro, como sanção à omissão de denunciar, existe exclusivamente no que diz respeito à evicção. Tal é a regra contida no próprio Código Civil (art. 456) e expressamente reafirmada no estatuto do processo (art. 70, inc. I: denunciação "a fim de que esta possa exercer o direito que da evicção lhe resulta")" (Intervenção de terceiros, p. 156).
} 
O projeto elimina, ainda, a hipótese de denunciação ao proprietário ou possuidor indireto na demanda promovida contra quem detenha a posse direta da coisa demandada. Em vista de a posse direta e a indireta coexistirem e de ser lícito aos titulares defendê-las, consideramos imprópria a exclusão dessa possibilidade, pois eles podem defender a posse por direito seu, por título próprio e de forma independente. O projeto, assim, foge da técnica processual, parecendo pretender manter, no art. 330, apenas a denunciação fundada na evicção, além de outra hipótese genérica, abrangendo todas as possibilidades, o que, todavia, não se faz completo pela utilidade do atual inciso II, do art. 70.

O aumento do tempo de suspensão do processo de dez ou trinta dias para dois meses (art. 328 do projeto) revela-se oportuno, diante da costumeira morosidade do Judiciário para efetivar a citação. Apesar disso, consideramos que, por se tratar de prazo máximo, ele deveria ser ainda mais dilatado, para que isso não comprometesse, por si só, a razoável duração do processo, principalmente se comparado a outros problemas que poderiam também afetar o regular trâmite das demandas. Assim, seria pertinente aguardar a citação até que ela se efetivasse, desde que o denunciante a promovesse em tempo razoável e não fícasse caracterizada má-fé, culpa ou desídia do denunciante ${ }^{384}$. Consideramos que seria benéfico ampliar o prazo e, ainda, conferir ao demandante a possibilidade de pedir prorrogação, de vez que ele é, em tese, o principal interessado na rápida solução do processo e a intervenção pode atender seus próprios interesses, o que fica ainda mais evidente quando ele for autor.

Apesar das mudanças em relação ao desenho atual do instituto, não se supre a deficiência do atual art. 71 do Código de Processo Civil, por não se ter precisado sobre a contagem desse prazo, ao estabelecer apenas que a citação deverá ser feita no prazo de dois meses. Esse prazo está associado ao tempo concedido ao denunciante para tomar as medidas cabíveis para viabilizar a citação - não se contando, por exemplo, o tempo para a expedição do mandado e para o cumprimento do mesmo pelo oficial de justiça - ao período em que o processo permanecerá suspenso ou ao intervalo entre o pedido do

\footnotetext{
${ }^{384}$ Alternativa viável seria aplicar o art. 333 do Código de Processo Civil português, que estabelece prazo de três meses para a citação ser realizada, facultando, no entanto, ao autor, caso isso não ocorra, requer o prosseguimento ou aguardá-la.
} 
denunciante e a citação do denunciado? Essa imprecisão é relevante e enseja controvérsia não solucionada.

Não há fundamento plausível, outrossim, para suprimir as alternativas de atuação do denunciado pelo autor, como existe atualmente no art. 74 do Código de Processo Civil. Este estabelece a possibilidade de o denunciado, caso a denunciação seja feita pelo autor, aditar a petição inicial ou, ao menos, acrescer um elemento novo ou conferir melhor contorno ao pedido e à causa de pedir. Apesar de se manter que o chamamento em garantia pode ser promovido por qualquer das partes, deixou-se de regular o que o chamado poderá fazer. Pelo sistema atual, o denunciado "poderá aditar a petição inicial”, procedendo-se a citação do réu apenas posteriormente. A ser suprimida essa previsão, não assistirá direito de o chamado aditar a petição inicial, não se indicando também quando será determinada a citação do réu, se após o comparecimento do chamado ou junto com a deste.

A eliminação dessa regra desvirtua o instituto, dado que a denunciação perderá, em parte, a característica de auxiliar os interesses do autor denunciante. Dessa maneira, restringe-se o auxílio, limitando-o a apresentar defesa, de vez que não será cabível o aditamento da petição inicial, visando tornar mais viável a procedência da ação principal e diminuir o risco da pretensão regressiva. Fica claro, pois, que o chamamento em garantia ficou em segundo plano, conferindo-se maior importância ao chamamento ao processo; nesse sentido, não andou bem o projeto, dado que ambos os institutos mantêm sua importância e não podem ser confundidos, apesar de que o chamamento em garantia não se marca apenas pela característica do regresso.

Do mesmo modo, inexiste justificativa para afastar o regramento sobre as atitudes do denunciado pelo réu, como está no art. 75 do Código. Como se sabe, nele se prevê, quando a denunciação for feita pelo réu, que o denunciado poderá aceitar a denunciação e contestar o pedido, ficar revel ou confessar os fatos alegados pelo autor. Essa disciplina com certeza fará menos falta que a relativa à denunciação pelo autor, pois bastará se aplicar o regime normal que define as consequências de comportamento do requerido em relação a qualquer ação.

Além disso, o instituto, tal como foi proposto, sequer resolve as questões controvertidas que se colocam, atualmente, em torno dele. 
Não prevê, por exemplo, qual será a posição do denunciado no processo principal: litisconsorte, assistente simples ou litisconsorcial. Essa questão é relevante, até mesmo para delimitar sua atuação e para definir quais atos pode praticar. Apesar disso, nada se disciplinou, o que dará ensejo à divergência e retirará a segurança jurídica para os envolvidos em demanda em que ocorra a intervenção.

Ademais, seria de rigor preocupar-se em regular a denunciação per saltum, autorizada pelo art. 456 do Código Civil, ao invés de limitar-se apenas à denunciação sucessiva, regida pelo art. 73 do Código de Processo Civil ${ }^{385}$. Perde-se a oportunidade de ajustar-se o processo à lei material, reaproximando o direito substancial do processual e possibilitando que a denunciação da lide seja realizada para qualquer um da cadeia dominial, desde que não acarrete prejuízo para a marcha e para a efetividade do processo, resguardada, evidentemente, futura ação direta ${ }^{386}$.

Além disso, não regula o projeto a possibilidade de condenação direta do denunciado frente ao adversário do denunciante, o que abordamos no capítulo 6.8. e é objeto de controvérsia. Para conferir segurança jurídica ao sistema, é necessário que a questão seja definida pelo legislador, observando também a efetividade da prestação jurisdicional, além do princípio da instrumentalidade. Diante dessa omissão, perde-se oportunidade de aperfeiçoar a denunciação, ao preocupar-se somente com a economia processual, mas não com o resultado prático que essa solução pode ensejar, como, por exemplo, a hipótese de o denunciante ser insolvente ou de o denunciado residir em local $\operatorname{ignorado}^{387}$.

Assim, as mudanças quanto à denunciação da lide (chamamento em garantia no projeto) são, de um modo geral, negativas, com algumas exceções como em relação à adequação da denominação e a exclusão da previsão da obrigatoriedade. Chegam a

\footnotetext{
${ }^{385}$ V. Egas Dirceu Moniz de Aragão, Sobre o chamamento à autoria, p. 57-66; Fredie Didier Júnior, A denunciação da lide e o art. 456 do novo CC: a denunciação per saltum e a "obrigatoriedade", p. 260-264; e Humberto Theodoro Júnior, Uma novidade no campo da intervenção de terceiros no processo civil: a denunciação da lide per saltum (ação direta), p. 304-311.

${ }^{386}$ V., nesse sentido, Cássio Scarpinella Bueno, Partes e terceiros no processo civil brasileiro, p. 249-251; e Cândido Rangel Dinamarco, que afirma que "está presente em primeiro plano uma regra de direito substancial, não de direito processual (...). A autorização de denunciar per saltum é somente uma projeção processual dessa regra substancial" (Intervenção de terceiros, p. 160).

${ }^{387}$ Cf. Egas Dirceu Moniz de Aragão, Sobre o chamamento à autoria, p. 66.
} 
representar retrocesso, de vez que deixam de ter identidade própria, faltando muito pouco para tornarem-se simples desdobramento do chamamento ao processo, o que decorre até da unificação do procedimento de ambos. 


\section{CONSIDERAÇÕES FINAIS}

O objetivo central deste estudo foi a análise do instituto da denunciação da lide no direito brasileiro, sobretudo no direito processual, visando abordar suas características, examinar as consequências da sua utilização e contribuir para que essa modalidade de intervenção de terceiro torne o processo mais efetivo, observando-se os princípios consagrados pelo legislador.

No sistema processual brasileiro, estabeleceu-se que as decisões judiciais só atingem as partes, de modo que não se admite, por influência do direito romano, a extensão dos limites subjetivos da coisa julgada a terceiros, de vez que ela é restrita aos litigantes participantes do contraditório. Excepcionalmente, no entanto, podem existir terceiros juridicamente interessados, em razão de terem vínculo de direito material com a relação jurídica objeto da demanda, de modo que podem ser afetados pelos efeitos da decisão judicial.

Nesse caso, o terceiro poderá intervir no processo - postulando seu ingresso ou sendo chamado a integrá-lo - e participar ativamente, assumindo a condição de parte na relação processual. Em razão disso, as garantias do devido processo legal e do contraditório também lhe devem ser asseguradas de forma ampla, até mesmo porque ele ficará vinculado à decisão e à coisa julgada.

Há diversas modalidades de intervenção de terceiros - oposição, nomeação à autoria, denunciação da lide e chamamento ao processo - a depender da natureza do interesse jurídico do terceiro e do seu grau de intensidade, sendo que há corrente que acrescenta outras modalidades - assistência, embargos de terceiro, intervenção de credores na execução e amicus curiae - ao que discordamos. Cada qual delas possui finalidade, fundamento, procedimentos e pressupostos distintos e próprios, havendo diferenças, ademais, em relação à iniciativa da intervenção. 
A denunciação da lide é uma das modalidades de intervenção provocada, podendo, consoante o direito processual pátrio vigente, dar-se por iniciativa do autor ou do réu. Pleiteada a intervenção de terceiro, caberá ao julgador analisar se os pressupostos estão presentes, a fim de determinar a citação do denunciado. Caso ela seja deferida, o terceiro será parte na lide secundária e ficar vinculado ao que for decidido.

A raiz do instituto advém do direito romano. A denunciação tem, a partir desse sistema, caráter de obrigatoriedade, de vez que era imprescindível dar ao denunciado conhecimento do litígio, a fim de possibilitar ao denunciante, na hipótese de sucumbir, mover posterior ação autônoma de indenização, viabilizando, pois, o seu ressarcimento. Caso não desse conhecimento e fosse vencido, não poderia valer-se da denunciação da lide. O denunciado, por sua vez, poderia manter-se inerte ou intervir, mas não seria, de qualquer maneira, condenado no mesmo processo, mas apenas em outra demanda. Prepondera, pois, a característica de indenização, dado que não se está a pretender que o denunciado dê efetivo auxílio ao denunciante, mas lhe garanta o ressarcimento dos prejuízos.

No direito germânico primitivo, o instituto, apesar de também ser obrigatório, recebeu novos contornos, diferentes dos do romano. O denunciado substituía no processo o denunciante, assumia a defesa deste, sendo que lhe era promovida, desde logo, ação de regresso, condicionado o ressarcimento à sucumbência. Assim, evitava-se que o denunciante tivesse que valer-se de processo autônomo para ser ressarcido, mesclando-se, portanto, o caráter de o terceiro auxiliar na defesa do denunciante e de indenizá-lo, sendo que, por haver substituição, prepondera a função de assistência.

O direito germânico primitivo influenciou o direito francês e o italiano, ao passo que o direito romano foi seguido pela atual legislação alemã e pelo direito lusitano, que, posteriormente, serviu de modelo ao direito brasileiro.

O instituto foi previsto no Regulamento 737, nos Códigos Estaduais e no Código de Processo Civil de 1939, nos quais adotou, por influência portuguesa, o direito romano.

No Código de Processo Civil de 1973, a denunciação da lide, como procuramos desenvolver nesse estudo, modernizou-se, ao fundir os modelos tradicionais e mesclar 
características do direito romano e do direito germânico antigo. O legislador conseguiu alcançar equilíbrio entre a rápida solução do litígio e o interesse público de economizar atividade jurisdicional e de evitar decisões conflitantes, conferindo relevância tanto ao dever de assistência processual, como ao de indenização, por meio da qual poderá formar título para ensejar o ressarcimento das perdas causadas ao denunciante. Valorizaram-se, portanto, os princípios da economia e da celeridade processual - evitando a repetição de atos e resolvendo duas demandas por meio de uma única instrução processual e sentença bem como da duração razoável do processo - atribuindo ao juiz meios para impedir eventual intuito procrastinador do denunciante e o retardamento da prestação da tutela jurisdicional - e da segurança jurídica - evitando-se decisões contraditórias e surpresa aos litigantes.

Pretendeu-se, com esse trabalho, demonstrar a importância do instituto, em razão de sua inegável relevância prática. O terceiro é chamado, por provocação de uma das partes, após o juiz verificar a presença dos requisitos legais, para auxiliar o denunciante na defesa de seus interesses e ser definida, no mesmo processo, eventual obrigação de indenizar o denunciante, na hipótese de este sucumbir.

Necessário se fez a análise da denominação do instituto, que no direito brasileiro não se mostra, na atualidade, apropriada tecnicamente, dado que denunciação da lide associa-se à ciência ao denunciado da existência do litígio. A partir das características do instituto vigente, conclui-se ser preferível denominá-lo, tecnicamente, de chamamento à autoria ou de chamamento em garantia, denominações que melhor revelam sua real função.

Além disso, a admissibilidade do instituto é restrita a processo de conhecimento, em razão da sua finalidade e natureza jurídica. A denunciação da lide é uma ação do denunciante movida em face do denunciado, na qual deverá ser proferida sentença, como fica claro a partir do disposto nas regras processuais que tratam do instituto e como se concluiu ser efetivamente adequado neste trabalho. Não é cabível o instituto na execução de título extrajudicial e no cumprimento de sentença, bem como, via de regra, nas medidas cautelares, exceto se a denunciação tiver cabimento na ação principal e o terceiro puder auxiliar a parte na defesa dos seus interesses, descartando qualquer pretensão de garantia ou de indenização na própria cautelar, o que transforma o instituto numa denunciação às avessas. 
Ademais, a obrigatoriedade da denunciação está associada, a partir da interpretação sistemática do direito material e do processual, à necessidade de o denunciante pleitear a intervenção para obter título executivo judicial, no mesmo processo, na hipótese de sucumbir na lide principal. Além disso, existe a obrigatoriedade da denunciação da lide nos casos de evicção, por força do disposto no art. 456 do Código Civil, o que, todavia, não se aplica às hipóteses dos incisos II e II, do art. 70, do Código de Processo Civil. De qualquer modo, a dita obrigatoriedade deve ser tratada de maneira temperada, sempre que for inviabilizada a aplicação do instituto, no caso de o denunciado não ser citado no prazo legal - mas não por culpa do denunciante - e o processo prosseguir sem a instauração da lide secundária, bem como no âmbito dos Juizados Especiais e no procedimento sumário, nos quais é incabível o instituto.

Quanto à posição processual do denunciado na lide principal, parece-nos inaceitável considerar que se trata de litisconsorte, constituindo imprecisão do texto legal, que não se ajustou às alterações do texto processual de 1973. Diante da falta de relação jurídica e do objetivo do denunciado auxiliar o denunciante, melhor considerar que se trata de assistência anômala, por ela não ser espontânea, mas provocada. Reputamos, outrossim, que, nas hipóteses dos incisos I e III, do art. 70, do Código de Ritos, o denunciado assume a posição de assistente simples, enquanto que, no caso do inciso II, será assistente litisconsorcial, dado que terá, na última hipótese, vínculo com o adversário do denunciante, ainda que não direto, ao menos transverso, em razão da natureza do direito tutelado.

O legislador processual pátrio estabeleceu hipóteses amplas para o cabimento da denunciação da lide no art. 70, não restringindo o instituto apenas à evicção. Admite-se que a denunciação também seja feita pelo possuidor direto ao proprietário ou possuidor indireto e também nos casos de direito regressivo, àquele que estiver obrigado, pela lei ou pelo contrato, a indenizar.

Consideramos não ser possível limitar, genericamente, o cabimento da denunciação da lide nos casos de direito regressivo (art. 70, III, do CPC), como defendem os que se filiam à corrente restritiva, que só admitem o instituto nos casos de ação de garantia, desde que não ocorra a introdução de fato ou fundamento jurídico novo. Essa visão parece-nos muito precária e pouca técnica, de vez que não se sabe qual a posição que 
o denunciado assumirá. Além disso, não se pode ignorar que uma das principais finalidades do instituto é a do denunciado auxiliar a defesa do denunciante, sendo que a simples introdução de fato novo ou de fundamento jurídico possivelmente não tem o condão de postergar a prestação da tutela jurisdicional ou de comprometer princípios constitucionais e processuais valorizados pelo sistema. Em razão disso, entendemos admissível a denunciação da lide do Estado ao agente público responsável pelo dano (art. $\left.37, \S 6^{\circ}, \mathrm{da} \mathrm{CF}\right)$.

Em relação ao segurador, as restrições à denunciação da lide que existem em relação a outras hipóteses são eliminadas ou, ao menos, atenuadas. Nesse sentido, admitese a denunciação no procedimento sumário (art. 280 do CPC); a introdução de fato ou fundamento jurídico novo; e que seja promovida ação direta da vítima do ato ilícito em face do segurador, por o contrato de seguro consistir em estipulação em favor de terceiro. Não é possível, todavia, ser permissivo e admitir que, feita a denunciação pelo segurado, tudo se possa fazer em relação ao segurador. Assim, não é possível condená-lo solidariamente ou a pagar diretamente indenização ao adversário do denunciante, caso a ação não lhe tenha sido promovida pela vítima, bem como é inadmissível a penhora dos direitos relativos ao seguro de responsabilidade civil, em razão de o cumprimento da denunciação ser condicionada ao pagamento da obrigação pelo denunciante.

Importante destacar, outrossim, que existe uma tendência genérica de não se admitir a intervenção de terceiros nas lides ajuizadas por consumidores, por se entender que o ingresso de terceiro no processo postergaria, por si só, a prestação da tutela jurisdicional, o que, todavia, não reputamos correto. Na realidade, a denunciação da lide é sempre cabível, exceto em se tratando do comerciante, em razão da restrição estabelecida pelo art. 88 do Código de Defesa do Consumidor limitar-se à hipótese do art. 13, devendo, pois, referido dispositivo ser interpretado restritivamente.

O estudo do instituto também se revela importante em relação à ação rescisória. Se houve a intervenção na ação originária que se pretende rescindir, o terceiro tem - na condição de parte - legitimidade ativa para ajuizar a rescisória, bem como passiva - em razão de haver reflexos que poderão atingi-lo, ainda que o pedido se reporte apenas a capítulo da ação principal. Caso não tenha sido deferida a denunciação da lide na ação, cuja sentença se pretende rescindir, não é facultado ao terceiro postular a rescisão, em vista 
da falta de legitimidade e de interesse - por não possuir vínculo com a ação principal e não ser atingido pela decisão (art. 472 do CPC).

No capítulo 6, tratamos das regras procedimentais para a denunciação da lide, cuidando dos diversos desdobramentos que pode haver, a depender do ato e da postura processual que o denunciante e o denunciado adotem. Buscamos abordar a repercussão desses diferentes comportamentos na continuidade do processo principal e da própria ação de regresso.

A partir de uma interpretação sistemática do direito material e do processual, cabível é a denunciação per saltum nas hipóteses de evicção (art. 456 do CC), ao passo que, em relação aos demais casos em que o instituto é cabível, só é permitida a denunciação sucessiva.

Recentemente, o projeto do novo Código de Processo Civil modificou radicalmente as regras que disciplinam o instituto. Procuramos abordá-las de maneira crítica, confrontando com o atual sistema vigente, e concluímos que as alterações, se forem acolhidas, não são positivas, exceto quanto à mudança da denominação e à eliminação da confusão em torno da dita obrigatoriedade de se denunciar. $O$ projeto unificou o procedimento da denunciação da lide (chamamento em garantia) com o do chamamento ao processo, faltando pouco para aquela tornar-se mero desdobramento deste, o que tecnicamente não é adequado, em razão de ambos possuírem identidade e características próprias. Deixou-se, ademais, de ajustar as normas processuais ao direito material e de enfrentar as questões polêmicas que são interpretadas de maneira diversa pela doutrina e pela jurisprudência.

Assim, entendemos que se trata de instituto moderno e de extrema relevância para viabilizar a intervenção do terceiro no processo, o qual não pode ser simplesmente descartado, em vista de ser instrumento eficaz para resolver, conjuntamente, duas demandas, não retardando, isoladamente, a prestação da tutela jurisdicional. Para aperfeiçoá-lo, necessário implantar mudança legislativa, porém não para alterar suas características e os positivos avanços alcançados pelo texto processual de 1973, mas para eliminar questões polêmicas e ajustar o direito processual ao direito material, incrementando, ainda mais, o instituto. 


\section{BIBLIOGRAFIA}

ARAGÃO, Egas Dirceu Moniz de. "Sobre o chamamento à autoria", in Revista da Associação dos Juízes do Rio Grande do Sul, ano 9, v. 25, jul/1982, p. 22-45.

. "Sobre o chamamento à autoria", in Revista de Processo, ano 7, v. 27, julset/1982, p. 49-67.

ALVIM, Eduardo Arruda. "Breves considerações sobre a assistência e o recurso de terceiro prejudicado", DIDIER JÚNIOR, Fredie e outros (coord.). O terceiro no processo civil brasileiro e assuntos correlatos, São Paulo: Revista dos Tribunais, 2010, p. 182190.

ALVIM NETTO, José Manoel de Arruda. Código de processo civil comentado, v. III, São Paulo: Revista dos Tribunais, 1976. 1977.

. Manual de direito processual civil, v. 2, São Paulo: Revista dos Tribunais,

ALVIM NETTO, José Manoel de Arruda; ASSIS, Araken; ALVIM, Eduardo Arruda Alvim. Comentários ao código de processo civil, Rio de Janeiro: GZ, 2012.

ALVIM, Thereza. Da assistência litisconsorcial no Código Brasileiro, extraído de Studi in Onore di Enrico Tullio Liebman, v. 2, Milão: Giuffrè, 1979, p. 1075-1081.

ASSIS, Araken. Manual da execução, 12ª ed., São Paulo: Revista dos Tribunais, 2009.

ASSIS MOURA, Mário. Da intervenção de terceiros, São Paulo: Saraiva, 1932.

BARBI, Celso Agrícola, Comentários ao Código de Processo Civil, v. 1, $2^{\mathrm{a}}$ ed., Rio de Janeiro: Forense, 1981.

BARBOSA MOREIRA, José Carlos. "Substituição das partes, litisconsórcio, assistência e intervenção de terceiros", Estudos sobre o novo Código de Processo Civil. Rio de Janeiro: Liber Juris, 1974.

Comentários ao código de processo civil, v. V, $15^{\mathrm{a}}$ ed., Rio de Janeiro: Forense, 2009.

BEDAQUE, José Roberto dos Santos. Direito e processo - influência do direito material sobre o processo, $6^{\mathrm{a}}$ ed., São Paulo: Malheiros, 2011.

BEVILAQUA, Clóvis. Código Civil dos Estados Unidos do Brasil, v. IV, 10ª ed., Rio de Janeiro: Paulo de Azevedo, 1955. 
BUENO, Cássio Scarpinella. Partes e terceiros no processo civil brasileiro, São Paulo: Saraiva, 2003.

. Amicus Curiae no Processo Civil Brasileiro: um terceiro enigmático, São Paulo: Saraiva, 2006.

"A denunciação da lide e o art. 456 do novo Código Civil", ASSIS, Araken e outros (coord.). Direito civil e processo: estudos em homenagem ao Professor Arruda Alvim, São Paulo: Revista dos Tribunais, 2008, p. 742-755.

. “Amicus Curiae: uma homenagem a Athos Gusmão Carneiro", DIDIER JÚNIOR, Fredie e outros (coord.). O terceiro no processo civil brasileiro e assuntos correlatos, São Paulo: Revista dos Tribunais, 2010, p. 160-167.

CAHALI, Yussef Said. Dos alimentos, 4ª ed., São Paulo: Revista dos Tribunais, 2002.

CALAMANDREI, Piero. "La chiamata in garanzía", in Opere giuridiche, v. V, Napoli: Morano, 1972.

CÂMARA, Alexandre Freitas. "Intervenção forçada de terceiros e responsabilidade civil do Estado", in Revista Dialética de Direito Processual, v. 39, jun/2006, p. 09-24.

. Ação rescisória, Rio de Janeiro, Lumen Juris, 2007.

CARNEIRO, Athos Gusmão. "Denunciação da lide e chamamento ao processo", in Revista da Associação dos Juízes do Rio Grande do Sul, ano 8, v. 21, mar/1981, p. 24-47.

- "O novo código civil e as alterações do instituto da denunciação da lide, de 'lege ferenda"”, in Revista Dialética de Direito Processual, v. 62, mai/2008, p. 09-14. Intervenção de terceiros, 19ª ed., São Paulo: Saraiva, 2010.

CARNELUTTI, Francesco. Sistema di diritto processuale civile, v. 1, $3^{\text {a }}$ ed., Padova, Cedam, 1936, v. 1.

CAVALIERI FILHO, SERGIO. Programa de responsabilidade civil, $6^{\mathrm{a}}$ ed., São Paulo: Malheiros, 2005.

CARVALHO, Fábio; BARIONI, Rodrigo. "Eficácia da sentença na denunciação da lide: execução direta do denunciado", in Revista Jurídica, v. 325, nov/2004, p. 70-74.

CASTRO FILHO, Sebastião de Oliveira. "Da evicção no direito brasileiro", ASSIS, Araken. Direito civil e processo - estudos em homenagem ao professor Arruda Alvim, São Paulo: Revista dos Tribunais, 2007.

CINTRA, Antônio Carlos de Araújo. Do chamamento à autoria, São Paulo: Revista dos Tribunais, 1973. 
CHIOVENDA, Giuseppe. Instituições de direito processual civil, v. I e II, $3^{\text {a }}$ ed., tradução J. Guimarães Menegale, São Paulo: Saraiva, 1969.

COLTRO, Antonio Carlos Mathias. "Alimentos no Código Civil de 2002: o direito material e o processual, com enfoque nos terceiros legitimados para a ação e a condição em que a integram, segundo o art. 1.698, última parte, do CC e rápida alusão ao Estatuto do Idoso", DIDIER JÚNIOR, Fredie e outros (coord.). O terceiro no processo civil brasileiro e assuntos correlatos, São Paulo: Revista dos Tribunais, 2010, p. 99-112.

COSTA, Alfredo de Araújo Lopes da. Da interveção de terceiros no processo, São Paulo: C. Teixeira \& Cia, 1930.

CRUZ, José Raimundo Gomes da. "O amicus curiae e os outros sujeitos do processo", DIDIER JÚNIOR, Fredie e outros (coord.). O terceiro no processo civil brasileiro e assuntos correlatos, São Paulo: Revista dos Tribunais, 2010, p. 324-335.

CUNHA, Leonardo José Carneiro da. "Breves notas sobre a denunciação da lide ao agente público pela Fazenda Pública", DIDIER JÚNIOR, Fredie e outros (coord.). $O$ terceiro no processo civil brasileiro e assuntos correlatos, São Paulo: Revista dos Tribunais, 2010, p. 336-341.

DALL'AGNOL JÚNIOR, Antonio Janir e outros. "Afirmação do amicus curiae no direito brasileiro", DIDIER JÚNIOR, Fredie e outros (coord.). O terceiro no processo civil brasileiro e assuntos correlatos, São Paulo: Revista dos Tribunais, 2010, p. 113-123.

DIAS, José de Aguiar. Da responsabilidade civil, 11ª ed., Rio de Janeiro: Renovar, 2006.

DIAS, Maria Berenice. O terceiro no processo, Rio de Janeiro: AIDE, 1993.

. Manual de direito de família, $5^{\text {a }}$ ed., São Paulo: Revista dos Tribunais, 2009.

DIDIER JÚNIOR, Fredie. Aspectos polêmicos e atuais sobre os terceiros no processo civil: e assuntos afins, São Paulo: Revista dos Tribunais, 2004.

"A nova intervenção de terceiro na ação de alimentos (art. 1.698 do Código Civil, de 2002)", in Revista Dialética de Direito Processual, v. 13, abr/2004, p. 1417.

"A denunciação da lide e o chamamento ao processo nas causas coletivas de consumo", in Revista Autônoma de Processo, v. 1, out-dez/2006, p. 61-68.

"A denunciação da lide e o art. 456 do novo CC: a denunciação per saltum e a 'obrigatoriedade",, DIDIER JÚNIOR, Fredie e outros (coord.). O terceiro no processo civil brasileiro e assuntos correlatos, São Paulo: Revista dos Tribunais, 2010, p. 260-264.

Curso de Direito Processual Civil, v. 1, 11ª ed., Salvador: Jus Podivm, 2009. 
DINAMARCO, Cândido Rangel. Litisconsórcio: um estudo sobre o litisconsórcio comum, unitário, necessário, facultativo (doutrina e jurisprudência), São Paulo: Revista dos Tribunais, 1984.

. Admissibilidade de denunciação da lide, in Revista de Processo, v. 22, n. 85, jan-mar/1997, p. 67-79.

Instituições de direito processual civil, v. II e v. III, $2^{\mathrm{a}}$ ed., São Paulo: Malheiros, 2002.

Intervenção de terceiros, $5^{\text {a }}$ ed., São Paulo: Malheiros, 2009.

DOTTI, Rogéria. "A denunciação da lide e a ilegitimidade passiva ad causam", DIDIER JÚNIOR, Fredie e outros (coord.). O terceiro no processo civil brasileiro e assuntos correlatos, São Paulo: Revista dos Tribunais, 2010, p. 463-469.

FERRAZ, Sérgio. Assistência litisconsorcial no direito processual civil, São Paulo: Revista dos Tribunais, 1979.

FERREIRA, William Santos; JORGE, Flávio Cheim. "Denunciações da lide sucessivas - Possibilidade - Condenação direta e exclusiva dos denunciados", in Revista de Processo, v. 82, abr-jun/1996, p. 308-318.

FIUZA, Ricardo. Código civil comentado, $7^{\mathrm{a}}$ ed., São Paulo: Saraiva, 2010.

FLAKS, Milton. Denunciação da lide, Rio de Janeiro: Forense, 1984.

FORNACIARI JÚNIOR, Clito. Reconhecimento jurídico do pedido, São Paulo: Revista dos Tribunais, 1977.

Da reconvenção no direito processual civil brasileiro, $2^{\mathrm{a}}$ ed., São Paulo: Saraiva, 1983.

. Processo civil: verso e reverso, São Paulo: Juarez de Oliveira, 2005.

Intervenção de terceiros no Anteprojeto, postado em 29 jun/2010. Disponível em <http://www.jurisdrops.blogspot.com.br>, acesso em 20 set/2012.

FUX, Luiz. Intervenção de terceiros: aspectos do instituto, São Paulo: Saraiva, 1990.

GIANESINI, Rita. Da revelia no processo civil brasileiro, São Paulo: Revista dos Tribunais, 1977.

GÓES, Gisele Santos Fernandes. "Amicus curiae e sua função nos processos objetivos. Necessidade de universalização do instituto para outras demandas", DIDIER JÚNIOR, Fredie e outros (coord.). O terceiro no processo civil brasileiro e assuntos correlatos, São Paulo: Revista dos Tribunais, 2010, p. 265-276.

GOMES, Orlando. Contratos, $18^{\mathrm{a}}$ ed., Rio de Janeiro: Forense, 1998. 
GONÇALVES, Aroldo Plínio. Da denunciação da lide, Rio de Janeiro: Forense, 1983.

GONÇALVES, Carlos Roberto. Direito civil brasileiro, v. III, $4^{\mathrm{a}}$ ed., São Paulo: Saraiva, 2007.

GRECO FILHO, Vicente. Direito Processual Civil Brasileiro, $12^{a}$ ed., São Paulo: Saraiva, 1981.

Da intervenção de terceiros, $3^{\text {a }}$ ed., São Paulo: Saraiva, 1991.

GUEDES, Clarissa Diniz e Raquel Bellini de Oliveira Salles. "A relação de regresso e a denunciação da lide prejudicada: da não imposição de ônus sucumbenciais ao denunciante", DIDIER JÚNIOR, Fredie e outros (coord.). O terceiro no processo civil brasileiro e assuntos correlatos, São Paulo: Revista dos Tribunais, 2010, p. 168175.

HAENDCHEN, Paulo Tadeu. Ação reivindicatória, $5^{\text {a }}$ ed., Saraiva: São Paulo, 1997.

LAMY, Eduardo de Avelar. "Intervenção de terceiros e o princípio da fungibilidade: hipóteses de aplicação", DIDIER JÚNIOR, Fredie e outros (coord.). O terceiro no processo civil brasileiro e assuntos correlatos, São Paulo: Revista dos Tribunais, 2010, p. 191-198.

LEONEL, Ricardo de Barros. "Recurso de sobreposição: novo procedimento e intervenção do amicus curiae", DIDIER JÚNIOR, Fredie e outros (coord.). O terceiro no processo civil brasileiro e assuntos correlatos, São Paulo: Revista dos Tribunais, 2010, p. 435-440.

LIEBMAN, Enrico Tullio. Manuale de diritto processuale civile, v. 1, $6^{\mathrm{a}}$ ed., Milão: Giuffrè, 2002.

LOTUFO, Renan. "Alimentos - obrigação avoenga", in Revista Brasileira de Direito de Família, v. 8, jan-mar/2001, p. 70-79.

LOPES, José Reinaldo Lima. Responsabilidade civil do fabricante e a defesa do consumidor, São Paulo: Revista dos Tribunais, 1992.

MALACHINI, Edson Ribas. "Seguro, resseguro, litisconsórcio e denunciação da lide", in Revista do Advogado, n. 47, mar/1996, p. 40-47.

MANDRIOLI, Crisanto. Corso de Diritto Processuale Civile, v. I, $2^{\mathrm{a}}$ ed., Turim: G. Giappichelli, 2002.

MEIRELLES, Hely Lopes. Direito administrativo brasileiro, $24^{\mathrm{a}}$ ed., São Paulo: Malheiros, 1999.

MELO, Gustavo de Medeiros. "A ação direta do terceiro prejudicado no seguro de responsabilidade civil - uma análise do sistema jurídico brasileiro"; DIDIER JÚNIOR, Fredie e outros (coord.). O terceiro no processo civil brasileiro e assuntos correlatos, São Paulo: Revista dos Tribunais, 2010, p. 284-303. 
MELLO, Celso Antônio Bandeira de. Curso de direito administrativo, $11^{\mathrm{a}}$ ed., São Paulo: Malheiros, 1999.

MESQUITA, José Ignácio Botelho de. Da ação de evicção, in Revista da Associação dos Juízes do Rio Grande do Sul, ano 8, v. 22, jul/1981, p. 81-101.

NEVES, Daniel Amorim Assumpção. "Intervenção de terceiros e revelia", in Revista Dialética de Direito Processual, v. 35, fev/2006, p. 19-37.

. "Intervenção de terceiros e a ação de alimentos", ASSIS, Araken. Direito civil e processo - estudos em homenagem ao professor Arruda Alvim, São Paulo: Revista dos Tribunais, 2007.

NERY JÚNIOR, Nélson e outra. Código de processo civil comentado, $9^{\mathrm{a}}$ ed., São Paulo: Revista dos Tribunais, 2006.

NETO, Abílio. Código de Processo Civil anotado. 14ª ed., Lisboa: Ediforum, 1997.

NUNES, Luiz Antônio Rizzato. Comentários ao código de defesa do consumidor, $4^{\mathrm{a}}$ ed., São Paulo: Saraiva, 2009.

OLIVEIRA, Guilherme Peres de. "Amicus curiae no controle concentrado de constitucionalidade brasileiro: amigo da corte ou sujeito parcial do processo?"; DIDIER JÚNIOR, Fredie e outros (coord.). O terceiro no processo civil brasileiro e assuntos correlatos, São Paulo: Revista dos Tribunais, 2010, p. 277-283.

PALMEIRA, Pedro. Da intervenção de terceiros nos principais sistemas legislativos: da oposição, Dissertação para o concurso de Direito Judiciário Civil apresentada na Faculdade Nacional de Direito da Universidade do Brasil, Recife, 1954.

PEREIRA, Caio Mário da Silva. Instituições de direito civil, v. III, $10^{\mathrm{a}}$ ed., Rio de Janeiro: Forense, 1999; v. IV, 13ª ed., Rio de Janeiro: Forense, 1999. Responsabilidade civil. 9a ed., Rio de Janeiro: Forense, 1999.

PELUSO, Antônio Cezar. "Chamamento ao processo em execução", in Jurisprudência Comentada, Revista de Processo, ano 1, v. 1, jan-mar/1976, p. 186-190. (coord). Código civil comentado, $4^{\mathrm{a}}$ ed., São Paulo: Manole, 2010.

PINHO, Américo Andrade. "A legitimidade do terceiro interessado para a ação rescisória"; DIDIER JÚNIOR, Fredie e outros (coord.). O terceiro no processo civil brasileiro $e$ assuntos correlatos, São Paulo: Revista dos Tribunais, 2010, p. 65-73.

RAGAZZI, José Luiz. Intervenção de terceiros e o código de defesa do consumidor, $2^{\mathrm{a}}$ ed., São Paulo: Verbatim, 2010.

REIS, José Alberto dos. Comentários ao Código de Processo Civil. Coimbra: Coimbra Editora, 1945. 
Intervenção de terceiros, Coimbra: Coimbra Editora, 1948.

ROCHA, José de Albuquerque. Nomeação à autoria, Saraiva: São Paulo, 1983.

ROSENBERG, Leo. Tratado de Derecho Procesal Civil, t. 1, tradução Ângela Romera Vera, Buenos Aires: EJEA, 1955.

RUIZ, Urbano. "Seguro de responsabilidade civil - Legitimidade da vítima do dano para promoção da ação de reparação contra a seguradora - Disciplina da matéria no novo Código Civil e no Código de Defesa do Consumidor", in Revista dos Tribunais, fev2004, p. 145-152.

SANCHES, Sydney. "Denunciação da lide", in Revista de Processo, ano 9, v. 34, abrjun/1984, p. 47-59.

Denunciação da lide no direito processual civil brasileiro, São Paulo: Revista dos Tribunais, 1984.

SANTOS, Moacyr Amaral. Primeiras linhas de direito processual civil, v. 2, $19^{\mathrm{a}}$ ed., São Paulo: Saraiva, 1998.

SATA, Salvatore. Diritto Processuale Civile, 10ª ed., Padova: Cedam, 1987.

SILVA, Ovídio Araújo Batista da. Comentários ao Código de Processo Civil, v. 1, 2a ed., São Paulo: Revista dos Tribunais, 2005.

SOUZA, Gelson Amaro. "Cumprimento de sentença diretamente contra o denunciado", in Revista dos Tribunais, ano 98, v. 886, ago/2009, p. 09-40.

STOCO, Rui. "Acidentes de trânsito - denunciação da seguradora à lide", in Revista dos Tribunais, ano 88, v. 768, out/1999, p. 119-122.

TALAMINI, Eduardo. Coisa julgada e sua revisão, São Paulo: Revista dos Tribunais, 2005.

THEODORO JÚNIOR, Humberto. "Intervenção de terceiros no processo civil: denunciação da lide e chamamento ao processo", in Revista de Processo, ano 4, v. 16, out-dez/1979, p. 49-58.

O novo Código Civil e as regras heterotópicas de natureza processual, in Revista síntese de direito civil e processual civil, ano 6, v. 32, nov-dez/2004, p. 1534.

. "Uma novidade no campo da intervenção de terceiros no processo civil: a denunciação da lide per saltum (ação direta)", DIDIER JÚNIOR, Fredie e outros (coord.). O terceiro no processo civil brasileiro e assuntos correlatos, São Paulo: Revista dos Tribunais, 2010, p. 304-311. 
TUCCI, José Rogério Cruz e. Ação monitória: lei 9.079 de 14.07.1995, $2^{a}$ ed. rev. e ampl., São Paulo: Revista dos Tribunais, 1997.

2001.

A causa petendi no processo civil, $2^{\mathrm{a}}$ ed., São Paulo: Revista dos Tribunais,

Lineamentos da nova reforma do $C P C, 2^{\mathrm{a}}$ ed., São Paulo: Revista dos Tribunais, 2002.

Causa de pedir e pedido no processo civil: (questões polêmicas), São Paulo: Revista dos Tribunais, 2002.

. Limites subjetivos da eficácia da sentença e da coisa julgada civil. Tese apresentada para concurso para o cargo de professor titular de Direito Processual Civil da Faculdade de Direito da Universidade de São Paulo, 2006.

TZIRULNIK, Ernesto. "O futuro do seguro de responsabilidade civil", in Revista dos Tribunais, ano 89, v. 782, dez/2000, p. 68-77.

USTÁRROZ, Daniel. A intervenção de terceiros no processo civil brasileiro, Porto Alegre: Livraria do Advogado, 2004.

VENOSA, Sílvio de Salvo. Direito civil: teoria geral das obrigações e teoria geral dos contratos, v. 2, São Paulo: Atlas, 2005.

WAGNER JUNIOR, Luiz Guilherme da Costa. "Considerações sobre a intervenção de terceiros trazida no art. 1.698 do CC: 'A questão da complementação dos alimentos pelos parentes"” )", DIDIER JÚNIOR, Fredie e outros (coord.). O terceiro no processo civil brasileiro e assuntos correlatos, São Paulo: Revista dos Tribunais, 2010, p. 352-360.

WAMBIER, Teresa Arruda Alvim e outro. "Amicus curiae", DIDIER JÚNIOR, Fredie e outros (coord.). O terceiro no processo civil brasileiro e assuntos correlatos, São Paulo: Revista dos Tribunais, 2010, p. 487-497.

WATANEBE, Kazuo. "Das ações de responsabilidade do fornecedor de produtos e serviços", Código brasileiro de defesa do consumidor comentado pelos Autores do Anteprojeto, GRINOVER, Ada Pellegrini e outros (coord.), $6^{\text {a }}$ ed., Rio de Janeiro: Forense, 2001.

YARSHELL, Flávio Luiz. "Evicção e denunciação da lide no novo Código Civil: contribuição ao direito bancário", in Revista de Direito Bancário e do Mercado de Capitais, v. 26, out-dez/2004, p. 35-40.

Ação rescisória: juízos rescindente e rescisório, São Paulo: Malheiros, 2005.

YOSHIKAWA, Eduardo Henrique de Oliveira. "Cabimento da denunciação da lide ao segurador nas ações de reparação de dano com fundamento no Código de defesa do consumidor (o falso chamamento ao processo do artigo 101 do CDC)", in Revista Dialética de Direito Processual, v. 23, fev/2005, p. 09-14. 


\section{RESUMO}

O objetivo central do presente trabalho é contribuir para o aprimoramento da aplicação da denunciação da lide, que é instituto valorizado, especialmente porque é modalidade de intervenção de terceiro que se ajusta aos princípios da economia e da celeridade processuais. Além disso, evita decisões contraditórias, facilita o cumprimento de provimentos jurisdicionais e vincula o terceiro à coisa julgada.

O instituto já era aplicado no direito romano, mudando radicalmente seus contornos no direito germânico primitivo. As características da denunciação da lide nesses dois sistemas são marcantes e influenciaram as demais legislações. A depender da preferência que se lhe pretenda conferir, o instituto estará mais associado ao caráter de assistência, auxiliando o terceiro na defesa do denunciante, ou de efetividade do processo, resolvendo duas demandas por meio de uma única instrução processual e sentença e possibilitando o reembolso do denunciante no mesmo feito.

Pretendeu-se, com esse trabalho, destacar a importância do instituto, que possui traços modernos no direito brasileiro, sendo tratado por disposições de direito processual, de direito material e de direito consumerista. Apesar dessas diversas previsões legais, ainda existem controvérsias e imprecisões, gerando relativa insegurança jurídica, que poderia ser afastada, porém o projeto do novo Código de Processo Civil não as resolveu e, para piorar, suprimiu diversos avanços, tornando o instituto praticamente um desdobramento do chamamento ao processo, em que pesem os requisitos para a aplicação deles serem tecnicamente distintos.

A inegável importância histórica da denunciação da lide, sua relevante utilidade e sua riqueza são evidentes, consistindo a modalidade de intervenção de terceiro mais utilizada na prática, o que justifica o estudo detido nesse trabalho.

Palavras chave: denunciação da lide, intervenção de terceiros, chamamento em garantia 


\begin{abstract}
$\underline{\text { ABSTRACT }}$
The main goal of this study is to contribute to the improvement of the valued institute of implead, specially because it is a kind of third intervention institute that adjusts itself to the procedure principles of economy and celerity. Furthermore, it avoids contradictory decisions, facilitates the enforcement of judicial decisions and attach a third party to the res judicata.
\end{abstract}

The institute was applied in roman law and changed its basis in earlier german law. Implead characteristics in both mentioned systems were remarkable and had an effect in other legal systems. It can be approached for different angles, or as an institute close to the so called assistência existing in brazilian law, by which the third party helps on defense of the impleader, or as an instrument to procedure effectiveness, solving two suits by only one proof production and only one decision, and enabling the refund to impleader on the same suit.

The intention of this work was to highlight the institute's magnitude, that is found in a modern conception, on procedure, material or consumers Brazilian laws. Despite been provided by law, there are still controversies and inaccuracies, what leads to judicial insecurity, that could be avoided. However, Civil Procedure Code's Project did not solve them, as well has suppressed many advances, making the institute a kind of the so called chamamento ao processo, a kind of "invitation to the suit", although their requirements be technically different.

The undeniable historical relevance of implead, its utility and value are manifest, and it is the third party proceedings most used, justifying the detailed study in this work

Keywords: implead, third party proceedings 


\section{RIASSUNTO}

Lo scopo centrale di questo studio è contribuire all'aggiornamento dell'applicazione della chiamata in garanzia, che è istituto valutato, specialmente perché è modalità di intervento di terzo in causa che si aggiusta ai principi di economia e celerità processuali. Inoltre, evita decisioni contraddittorie, facilita l'adempimento delle sentenze e collega il terzo alla res judicata.

L'istituto era già applicato nel diritto romano ed è stato modificato nel diritto germanico primitivo. Le caratteristiche della chiamata in garanzia in questi due sistemi sono eccezionali e hanno influenzato altre legislazioni. L'istituto può essere visto da due angoli, o come istituto prossimo all'assistência della legislazione brasiliana, con cui il terzo guida in linea di difesa del garante, o voltato alla effettività del processo, con la soluzione di due processi con un'unica istruzione e una sentenza, permettendo il rimborso del garante nello stesso processo.

Se è preteso, con questo studio, distaccare l'importanza dell'istituto, che ha aspetti moderni nella legislazione brasiliana, esistendo disposizioni nei codici di diritto processuale, materiale e dei consumatori. Nonostante sia previsto dalla legge, c'è l'hanno controversie e inesattezze, che generano insicurezza giuridica, che potrebbe essere evitata. Tuttavia, il progetto di Codice di Procedura Civile non le ha risolto, come ha soppresso molti progressi, facendo dall'istituto una specie di chiamata semplice, nonostante i requisiti dei due istituti siano abbastanza diversi in Brasile.

Questo lavoro è, poi, giustificato dall'importanza storica e dall'utilità pratica della chiamata in garanzia, essendo specie d'intervento di terzo in causa più usata.

Parole chiavi: chiamata in garanzia, intervento di terzo in causa 